\title{
Impacts of Vehicle Weight \& Dimension Regulations on Railway Freight Transportation
}

BY

Ahmed Mohmed Gadi

\author{
A Thesis Submitted to the \\ Faculty of Graduate Studies in Partial Fulfillment \\ of the Requirements for the Degree of \\ Doctor of Philosophy
}

Department of Civil Engineering

Winnipeg, Manitoba

APRIL, 1991

(C) MCMXCI Ahmed Mohmed Gadi 
Canadian Theses Service Service des thèses canadiennes

OHawa Canada

KIA ON4

The author has granted an irrevocable nonexclusive licence allowing the National Library of Canada to reproduce, ban, distribute or sell copies of his/her thesis by any means and in any form or format, making this thesis available to interested persons.

The author retains ownership of the copyright in his/her thesis. Neither the thesis nor substantial extracts from it may be printed or otherwise reproduced without his/her permission.
L'auteur a accordé une licence irrévocable et non exclusive permettant à la Bibliothèque nationale du Canada de reproduire, prêter. distribuer ou vendre des copies de sa thèse de quelque manière et sous quelque forme que ce soit pour mettre des exemplaires de cette thèse à la disposition des personnes intéressées.

L'auteur conserve la proprięté du droit d'auteur qui protège sa thèse. Ni la thèse ni des extraits substantiels de celle-ci ne doivent être imprimés ou autrement reproduits sans son autorisation. 
IMPACTS OF VEHICLE WEIGHT AND DIMENSION REGULATIONS

ON RAILWAY FREIGHT TRANSPORTATION

BY

AHMED MOHMED GADI

A thesis submitted to the Faculty of Graduate Studies of the University of Manitoba in partial fulfillment of the requirements of the degree of

DOCTOR OF PHILOSOPHY

\section{(c) 1991}

Permission has been granted to the LIBRARY OF THE UNIVERSITY OF MANITOBA to lend or sell copies of this thesis. to the NATIONAL LIBRARY OF CANADA to inicrofilm this thesis and to lend or sell copies of the film, and UNIVERSITY MICROFILMS to publisin an abstract of this thesis.

The author reserves other publication rights, and neither the thesis nor extensive extracts from it may be printed or otherwise reproduced without the author's written permission. 


\section{ABSTRACT}

The transportation of goods across Canada by road was until recently restricted by vehicle weight and dimension (VWD) regulations set by the various provincial and territorial governments. Each of the ten provinces and both territories had their own sets of VWD regulations to govern the trucking industry. This fractured supervisory authority complicated the interprovincial transportation of highway freight and reduced its efficiency. It was necessary when transporting goods by truck to configure the shipment and vehicle to comply with the most restrictive set of regulations encountered enroute. The far reaching effects of these circumstances are apparent when it is considered that Canada is geographically linear. No routing alternatives exist to the transiting of each and every intervening jurisdiction between origin and destination.

The need to rationalize the operating environment of the Canadian trucking industry has been recognized. The task of performing this long mooted reordering has finally been undertaken, and has come to involve both tiers of government, the trucking industry and the research community. This process has recently resulted in standard national and regional regulatory agreements.

The main objective of this research is to develop mathematical freight demand models using the most recent data available. These models are then applied to determine the impacts of changing trucking service characteristics as a result of the VWD agreements on the market share of freight carried by the railway mode. 
Econometric abstract mode models are developed using several periods of data. The methodology of model development involves the use of origin/destination socioeconomic indicators and modal service variables in combination with interprovincial trucking freight movement. A model for each of the four largest Statistics Canada commodity section classifications is estimated. The four commodity sections modeled are "Food, feed, beverages and tobacco," "Crude materials, inedible," "Fabricated materials, inedible," and "End products, inedible."

The impact of the newly implemented vehicle weight and dimension reform on the rail transportation industry is analyzed and railway industry improvements aimed at maintaining its market share are presented. The analysis shows that the VWD agreements will result in different impacts on the four different commodity sections freight carried by the railway industry. Link-by-link percentages reduction in railway cost and/or door-to-door travel time are determined in order for rail to keep its existing market share for each commodity. Generally, the results predicted by the models show that railway user cost reductions should be moderate, and likely less than the level of inflation over the period of time when trucking converts its fleet to take advantage of the new regulations. The link-by-link railway revenue loss for each freight section and the total loss in railway revenue are presented. 


\section{ACKNOWLEDGEMENT}

This work has been carried out under the direct supervision of Dr. Afif Hassen Soliman, professor of Civil Engineering at the University of Manitoba. I wish to offer my sincere gratitude and appreciation to him for initiating this research, for his guidance and invaluable advice and encouragement during the course of this study and otherwise. Dr. Soliman as long as I live I will not forget those beautiful days I worked with you.

A special thank you is also extended to Mr. David Anthony Wyatt, graduate student and computer advisor from the Department of City Planning of the University of Manitoba who devoted long hours to help me in this research. I am very grateful to you David for your assistance and advice throughout the whole project and during the preparation of this thesis.

I would like to extend my thanks to the members of my advisory and examining committee: Dr. C.R. Bector of the Department of Acturial and Mangement Sciences of the University of Manitoba, Dr. A.M. Lansdown of the Department of Civil Engineering of the University of Manitoba and Dr. A. Khan of the Department of Civil Engineering at Carlton University for their support, assistance and suggestions throughout my program and for reviewing this thesis work and for their valuable comments.

A special thank-you is also extended to the Civil Engineering Department of El Fateh University in Tripoli, the Libyan Secretariat of Education, and the Cana- 
dian Bureau for International Education (CBIE) for supporting me in undertaking a Doctoral programme at University of Manitoba.

I wish to thank Mr. R. Saboungi, Senior Development Officer for the Technology Application Division of Transport Canada's Transportation Development Centre in Montréal, Messrs. A. Gibson, B. Ornstein and B. Brenie of CN Rail in Montréal, and Mr. R. Semotiuk, Economic Analyst for the For-Hire Trucking Survey, Transportation Division, Statistics Canada, for their cooperation in Data acquisition. I also wish to express my appreciation for information provided by Mr. R. Engel, President \& CEO of Atomic Group, Mr. G. Reimer, Vice-president of Reimer Express Enterprises $L t d$., Professor R. Lande of Concordia University and the assistance of Canadian Motorways Ltd. and Day \& Ross Inc.

The financial assistance of the Natural Science and Engineering Research Council of Canada is gratefully acknowledged.

Finally, a very special and deep thank you goes to my wife Fatma, my daughter Rouida, my two sons Zakariya and Yahay, my parents, my brothers and sisters, for their encouragement and understanding in allowing me to devote so many long days away from home over the period of my study.

Thank you, my advisor, Dr. Afifi Soliman

Thank you, my friend, David

Thank you, my wife, Fatma

Ahmed Gadi

April, 1991

Winnipeg, Manitoba 


\section{NOMENCLATURE}

\section{Keywords}

COMMODITY GROUPING

FREIGHT MODELLING

FREIGHT TRANSPORTATION

MODAL SPLIT

MODE CHOICE

REGULATORY REFORM

TRUCKING AND RAILWAY TRANSPORTATION

V W D REGULATION

\section{Terms}

Unless indicated otherwise, the terms "tonnage" and "volume" are used interchangeably to refer to the amount of freight, measured in tonnes.

\section{Abbreviations}

AASHTO American Association of State Highway and Transportation Officials CCMTA Canadian Conference of Motor Transport Administrators

CFTM Canadian Freight Transportation Model

CMI "Crude materials, inedible" commodity classification

CN Canadian National Railways 
CP Canadian Pacific Railway

CTC Canadian Transport Commission

CSCE Canadian Society for Civil Engineering

EPI "End products, inedible" commodity classification

FFB\&T "Food, feed, beverages and tobacco" commodity classification

FMI "Fabricated materials, inedible" commodity classification

GVW Gross Vehicle Weight

NA 1988 VWD National Agreement

RTAC Roads and Transportation Association of Canada

SAS Statistical Analysis System

SCC Standard Commodity Classification

STCC Standard Transportation Commodity Code

$\mathrm{T}$ (ton) Imperial ton (2000 lbs or $907.185 \mathrm{~kg}$ )

$\mathrm{t}$ (tomne) Metric ton $(1000 \mathrm{~kg}$ )

VWD Vehicle Weight(s) and Dimension(s)

WA 1988 WD Western Agreement 


\section{TABLE OF CONTENTS}

ABSTRACT . . . . . . . . . . . . . . . . . . . . .

ACKNOWLEDGEMENT . . . . . . . . . . . . . . . ii

NOMENCLATURE . . . . . . . . . . . . . . . . . . . . v

Keywords . . . . . . . . . . . . . . . . . . . . . . . . . . . . . .

Terms . . . . . . . . . . . . . . . . . . . . . . $\nabla$

Abbreviations . . . . . . . . . . . . . . . . . . . . . . . . . . . . v

TABLE OF CONTENTS . . . . . . . . . . . . . . . . . . . . . . vii

LIST OF TABLES . . . . . . . . . . . . . . . . . . . . . . . . . . . . . . . . $\quad$.

LIST OF EIGURES . . . . . . . . . . . . . . . . . . . . . . . . xiv

CH $f_{4}$ PTER 1 INTRODUCTION . . . . . . . . . . . . . . . . . . . 1

1.1 The Research Need . . . . . . . . . . . . . . . . . . . . . . . 1

1.2 Research Purposes and Objectives . . . . . . . . . . . . . . . . . 3

1.3 The Significance and Potential of this Research . . . . . . . . . . . 3

1.4 Thesis Organization . . . . . . . . . . . . . . . . . . . . . . . 4

1.5 Research Achievement and Publications . . . . . . . . . . . . . . 4

CHAPTER 2 CANADIAN VWD REGULATIONS . . . . . . . . . . 7

2.1 The Development of VWD Regulation in Canada . . . . . . . . . . 8

2.1.1 1987 RTAC Scenarios . . . . . . . . . . . . . . . . . . . . . . 11

2.1.2 1988 National Agreement . . . . . . . . . . . . . . . . . . . . 13

2.1.3 1988 Western Agreement . . . . . . . . . . . . . . . . . . . . 13

CHAPTER 3 FREIGHT TRANSPORTATION MODELLING REVIEW. 15

3.1 Previous Research . . . . . . . . . . . . . . . . . . . . . . . . 15

3.1.1 Freight Modelling Approach Classification . . . . . . . . . . . . . 16

3.1.2 Some Widely Used Freight Models . . . . . . . . . . . . . . . . 18

3.1.2.1 Market Share Models . . . . . . . . . . . . . . . . . . . . . 18

3.1.2.2 Input-Output Models . . . . . . . . . . . . . . . . . . . . . 18

3.1.2.3 Inventory-Theoretic Mode Choice Model . . . . . . . . . . . . . 19

3.1.2.4 Gravity Type Models . . . . . . . . . . . . . . . . . . . . . 20 
3.1.2.5 Econometric Abstract Mode Models . . . . . . . . . . . . . . . 21

3.1.3 Canadian Freight Transportation Studies . . . . . . . . . . . . . 22

3.1.3.1 CTC Model . . . . . . . . . . . . . . . . . . . . 22

3.1.3.2 Oum Model . . . . . . . . . . . . . . . . . . . . 25

3.2 Factors Affecting Users' Mode Choice . . . . . . . . . . . . . 27

3.3 Guiding Principles From the Literature . . . . . . . . . . . . . . . 31

CHAPTER 4 DATA COLLECTION \& ANALYSIS . . . . . . . . 33

4.1 Source of Data

4.2 Data Organization . . . . . . . . . . . . 37

4.3 Rail/Truck Competition \& Modal Split . . . . . . . . . . . . . . 39

4.3.1 Freight Movement Among the Central and Western Provinces 1978-87 40

4.3.2 Competition/Modal Split by Commdity Type . . . . . . . . . . 64

4.3.2.1 FFB\&T: Commodity Movement and Composition . . . . . . . 67

4.3.2.2 CMII: Commodity Movement and Composition . . . . . . . . . .68

4.3.2.3 FMI: Commodity Novement and Composition . . . . . . . . . 70

4.3.2.4 EPI: Commodity Morement and Composition . . . . . . . . . .74

CHAPTER 5 MODEL DEVELOPMENT \& CALIBRATIONS . . . 79

5.1 The Selected Models . . . . . . . . . . . . . . . . . . . . 80

5.2 Validity of Developed Models . . . . . . . . . . . . . . . . . . 82

5.2 .1 Pragmatic Validation . . . . . . . . . . . . . . . . . . . . 82

5.2 .2 Statistical Validation . . . . . . . . . . . . . . . . . . . . 83

5.2 .3 Analysis of Variance . . . . . . . . . . . . . . . . . . 90

5.2 .4 Parameter Estimates . . . . . . . . . . . . . . . . . . . . .92

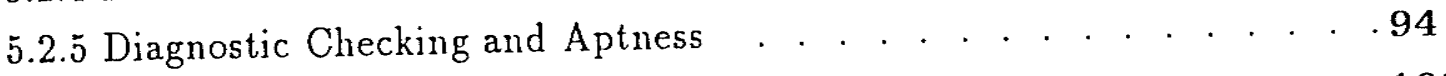

CHAPTER 6 IMPACTS OF VWD REFORM . . . . . . . . . . 103

6.1 Impact on Trucking . . . . . . . . . . . . . . . . 103

6.2 Impact on Railways . . . . . . . . . . . . . . . . . . . . 105

6.2.1 Link-by-Link Rail Cost and Travel Time Reductions . . . . . . . .109

6.2.2 Link-by-Link Rail Revenue Loss . . . . . . . . . . . . . . . . .117

CHAPTER 7 CONCLUSIONS AND RECOMMENDATIONS . . . .121

7.1 Conclusions $\ldots \ldots \ldots . . . . . .121$

7.2 Recommendations . . . . . . . . . . . . . . . . . . . 126

BIBLIOGRAPHY $\ldots \ldots \ldots$

APPENDICES . . . . . . . . . . . . . . . . . . . . . . . . .

APPENDIX 1

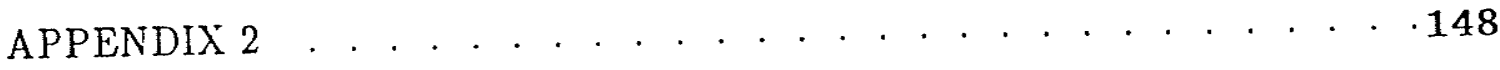

APPENDIX $3 \ldots \ldots \ldots$ 


$$
-i x-
$$

A 3.1 Accomplishments: . . . . . . . . . . . . . . . . . . . . . 155 APPENDIX $4 \ldots \ldots \ldots$ APPENDIX $5 \ldots \ldots \ldots$ APPENDIX $6 \ldots \ldots \ldots 171$ 


\section{LIST OF TABLES}

2.1 VWD Regulations in Canada (Maximum Limits) . . . . . . . . . . 11

2.21987 RTAC Scenarios . . . . . . . . . . . . . . . . . . . . . . 12

2.31988 National Agreement . . . . . . . . . . . . . . . . . . . . 13

2.41988 Western Agreement . . . . . . . . . . . . . . . . . . . . . . 14

4.1 Commodity Sections . . . . . . . . . . . . . . . . . . . . . . . 38

4.2 Railway Tonnage $\left(\times 10^{3} t\right)$ Moved Form Québec to the Other Western and Central Provinces 1978 - 1987 . . . . . . . . . . . . . . . .46

4.3 Trucking Tonnage $\left(\times 10^{3} t\right)$ Moved From Québec to the Other Western and Central Provinces $1978-1987$. . . . . . . . . . . . . . . . 46

4.4 Railway Tonnage $\left(\times 10^{3} t\right)$ Moved From Ontario to the Other Western and Central Provinces $1978-1987$. . . . . . . . . . . . . . . . . . . 49

4.5 Trucking Tonnage $\left(\times 10^{3} t\right)$ Moved From Ontario to the Other West ern and Central Provinces $1978-1987$. . . . . . . . . . . . . . . . . 49

4.6 Railway Tonnage $\left(\times 10^{3} t\right)$ Moved From Manitoba to the Other Western and Central Provinces 1978 - 1987 . . . . . . . . . . . . 52

4.7 Trucking Tonnage $\left(\times 10^{3} t\right)$ Moved From Manitoba to the Other Western and Central Provinces $1978-1987$. . . . . . . . . . . . . 52

4.8 Railway Tonnage $\left(\times 10^{3} t\right)$ Moved From Saskatchewan to the Other Western and Central Prorinces $1978-1987$. . . . . . . . . . . . 55

4.9 Trucking Tonnage $\left(\times 10^{3} t\right)$ Moved From Saskatchewan to the Other Western and Central Provinces $1978-1987$. . . . . . . . . . . . . 55

4.10 Railway Tonnage $\left(\times 10^{3} t\right)$ Moved From Alberta to the Other Western and Central Provinces $1978-1987$. . . . . . . . . . . . . . . .58

4.11 Trucking Tonnage $\left(\times 10^{3} t\right)$ Moved From Alberta to the Other Western and Central Provinces $1978-1987$. . . . . . . . . . . . . .58

4.12 Railway Tonnage $\left(\times 10^{3} t\right)$ Moved From British Columbia to the Other Western and Central Provinces $1978-1987$. . . . . . . . . . .61

4.13 Trucking Tonnage $\left(\times 10^{3} t\right)$ Moved From British Columbia to the Other Western and Central Provinces $1978-1987$. . . . . . . . . . .61

4.14 Truck/Rail Modal Split by Commodity Section Over Short, Medium and Long Ranges 1987 (\%) 
4.15 FFB\&T Link-by-Link Share of Interprovincial Railway Volume $1987(\%)$. . . . . . . . . . . . . . . . . . . . . . . . . . . .68

4.16 FFB\&T Link-by-Link Share of Interprovincial Trucking Volume $1987(\%)$. . . . . . . . . . . . . . . . . . . . . . . . . 68

4.17 Railway Food, Feed, Beverages and Tobacco Composition . . . . . . 69

4.18 Trucking Food, Feed, Beverages and Tobacco Composition . . . . . . . . 70

4.19 CMI Link-by-Link Share of Interprovincial Railway Volume 198

(\%). . . . . . . . . . . . . . . . . . . . . . .71

4.20 CMI Link-by-Link Share of Interprovincial Trucking Volume 1987

(\%). . . . . . . . . . . . . . . . . . . . . . . . . . . 71

4.21 Railway Crude Materials Composition . . . . . . . . . . . . . . . 72

4.22 Trucking Crude Materials Composition . . . . . . . . . . . . . . 72

4.23 FMI Link-by-Link Share of Interprovincial Railway Volume 1987

(\%). . . . . . . . . . . . . . . . . . . . . . . . . . . . . . 73

4.24 FMI Link-by-Link Share of Interprovincial Trucking Volume 1987
$(\%)$. . . . . . . . . . . . . . . . . . . . . . . . . . . . . . . . . . . . 73

4.25 Railway Fabricated Materials Composition . . . . . . . . . . . . . 74

4.26 Trucking Fabricated Materials Composition . . . . . . . . . . . . . . 75

4.27 EPI Link-by-Link Share of Interprovincial Railway Volume 1987

(\%) . . . . . . . . . . . . . . . . . . . . . . . . . . . . 77

4.28 EPI Link-by-Link Share of Interprovincial Trucking Volume 1987

$(\%)$. . . . . . . . . . . . . . . . . . . . . . . . . . . . . . 77

4.29 Railway End Products Composition . . . . . . . . . . . . . . . . . . 78

4.30 Trucking End Products Composition . . . . . . . . . . . . . . . . . 78

5.1 FFB\&T: Analysis of Variance . . . . . . . . . . . . . . . . . . . . 91

5.2 CMII: Analysis of Variance . . . . . . . . . . . . . . . . . . . . . . . 91

5.3 FMI: Analysis of Variance . . . . . . . . . . . . . . . . . . . . . 91

5.4 EPI: Analysis of Variance . . . . . . . . . . . . . . . . . . . . . . 92

5.5 FFB\&T: Parameter Estimates . . . . . . . . . . . . . . . . . . . 92

5.6 CMI: Parameter Estimates . . . . . . . . . . . . . . . . . . . . . 93

5.7 FMI: Parameter Estimates . . . . . . . . . . . . . . . . . . . . . 93

5.8 EPI: Parameter Estimates . . . . . . . . . . . . . . . . . . . . .94

5.9 FFB\&T: Univariate Analysis . . . . . . . . . . . . . . . . . . . 99

5.10 CMI: Univariate Analysis . . . . . . . . . . . . . . . . . . . . . 100

5.11 FMI: Univariate Analysis . . . . . . . . . . . . . . . . . . . . . 101

5.12 EPI: Univariate Analysis . . . . . . . . . . . . . . . . . . . . . . 102

6.1 RTAC Trucking Cost Reductions (\%) Weight-out Commodities . . . . . 104

6.2 FFB\&T Annual Railway Cost Reductions (\%) Weight-out Commodities . . . . . . . . . . . . . . . . . . . . . . . . . . . . . 109

6.3 FFB\&T Annual Railway Travel Time Reductions (\%) Weight-out Commodities . . . . . . . . . . . . . . . . . . . . . . . . . . . 110

6.4 FFB\&T Competing Railway Service Improvements Cube-out Commodities . . . . . . . . . . . . . . . . . . . . . . . 111 
6.5 CMI Annual Railway Cost Reductions (\%) Weight-out Commodities . . . . . . . . . . . . . . . . . . . . . . . . 111

6.6 CMI Annual Railway Travel Time Reductions (\%) Weight-out Commodities . . . . . . . . . . . . . . . . . . . . . . . . . . 112

6.7 CMI Competing Railway Service Improvements Cube-out Commodities . . . . . . . . . . . . . . . . . . . . . . . . . $\mathbf{1 1 3}$

6.8 FMI Annual Railway Cost Reductions (\%) Weight-out Commodities . . . . . . . . . . . . . . . . . . . . . . . . . 113

6.9 FMI Competing Railway Service Improvements Cube-out Commodities . . . . . . . . . . . . . . . . . . . . . . . . . . . . $\mathbf{1 1 4}$

6.10 FMI Annual Railway Travel Time Reductions (\%) Weight-out Commodities . . . . . . . . . . . . . . . . . . . . . . . . . . .114

6.11 EPI Annual Railway Cost Reductions (\%) Weight-out Commodities . . . . . . . . . . . . . . . . . . . . . . . . . . . 115

6.12 EPI Annual Railway Travel Time Reductions (\%) Weight-out Commodities . . . . . . . . . . . . . . . . . . . . . . . . . . . . 116

6.13 EPI Competing Railway Service Improvements Cube-out Commodities . . . . . . . . . . . . . . . . . . . . . . . . . 116

6.14 FFB\&T Link-by-Link Distribution of Interprovincial Railway Revenue Loss $(\%)$. . . . . . . . . . . . . . . . . . . . . . . . . . 117

6.15 CMI Link-by-Link Distribution of Interprovincial Railway Revenue Loss $(\%)$. . . . . . . . . . . . . . . . . . . . . . . . . . . . 118

6.16 FMI Link-by-Link Distribution of Interprovincial Railway Revenue Loss (\%) . . . . . . . . . . . . . . . . . . . . . . . . . . . . 118

6.17 EPI Link-by-Link Distribution of Interprovincial Railway Revenue Loss (\%) . . . . . . . . . . . . . . . . . . . . . . . . . . . . 119

A 4.1 Truck/Rail Modal Split by Commodity Section Tonnage between Ontario and Québec $1983(\%)$. . . . . . . . . . . . . . . . . . 157

A 4.2 Truck/Rail Modal Split by Commodity Section Tonnage between Ontario and Québec $1984(\%)$. . . . . . . . . . . . . . . . . .

A 4.3 Truck/Rail Modal Split by Commodity Section Tonnage between Ontario and Québec 1986(\%) . . . . . . . . . . . . . . . . . . . 157

A 4.4 Truck/Rail Modal Split by Commodity Section Tonnage between Ontario and Québec $1987(\%)$. . . . . . . . . . . . . . . . . . 157

A 4.5 Truck/Rail Modal Split by Commodity Section Tonnage between Ontario and Manitoba $1983(\%)$. . . . . . . . . . . . . . . . . . 158

A 4.6 Truck/Rail Modal Split by Commodity Section Tonnage between Ontario and Manitoba $1984(\%)$. . . . . . . . . . . . . . . . . . . 158

A 4.7 Truck/Rail Modal Split by Commodity Section Tonnage between Ontario and Manitoba $1986(\%)$. . . . . . . . . . . . . . . . . . . . . . 158

A 4.8 Truck/Rail Modal Split by Conmodity Section Tonnage between Ontario and Manitoba 1987 (\%) 
A 4.9 Truck/Rail Modal Split by Commodity Section Tonnage between Ontario and Saskatchewan $1983(\%)$. . . . . . . . . . . . . . . 159

A 4.10 Truck/Rail Modal Split by Commodity Section Tonnage between Ontario and Saskatchewan $1984(\%)$. . . . . . . . . . . . . . . 159

A 4.11 Truck/Rail Modal Split by Commodity Section Tonnage between Ontario and Saskatchewan $1986(\%)$. . . . . . . . . . . . . 159

A 4.12 Truck/Rail Modal Split by Commodity Section Tonnage between Ontario and Saskatchewan $1987(\%)$. . . . . . . . . . . . . . . 159

A 4.13 Truck/Rail Modal Split by Commodity Section Tonnage between Ontario and Alberta $1983(\%)$. . . . . . . . . . . . . . . . . . . 160

A 4.14 Truck/Rail Modal Split by Commodity Section Tonnage between Ontario and Alberta $1984(\%)$. . . . . . . . . . . . . . . . . . 160

A 4.15 Truck/Rail Modal Split by Commodity Section Tonnage between Ontario and Alberta $1986(\%)$. . . . . . . . . . . . . . . . . . 160

A 4.16 Truck/Rail Modal Split by Commodity Section Tonnage between Ontario and Alberta $1987(\%)$. . . . . . . . . . . . . . . . . 160

A 4.17 Truck/Rail Modal Split by Commodity Section Tonnage between Ontario and British Columbia $1983(\%)$. . . . . . . . . . . . . 161

A 4.18 Truck/Rail Modal Split by Commodity Section Tonnage between Ontario and British Columbia $1984(\%)$. . . . . . . . . . . . . . 161

A 4.19 Truck/Rail Modal Split by Commodity Section Tonnage between Ontario and British Colımbia $1986(\%)$. . . . . . . . . . . . . . 161

A 4.20 Truck/Rail Modal Split by Commodity Section Tonnage between Ontario and British Columbia $1987(\%)$. . . . . . . . . . . . 161

A 6.1 FFB\&T Link-by-Link Share of Interprovincial Railway Volume

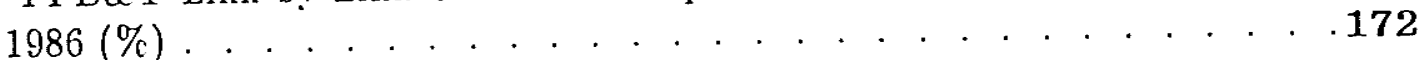

A 6.2 FFB\&T Link-by-Link Share of Interprovincial Trucking Volume

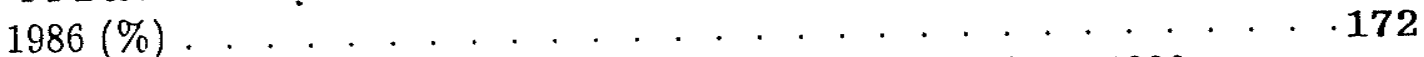

A 6.3 CMI Link-by-Link Share of Interprovincial Railway Volume 1986 (\%) . . . . . . . . . . . . . . . . 173

A 6.4 CMI Link-by-Link Share of Interprovincial Trucking Volume 1986 (\%) . . . . . . . . . . . .

A 6.5 FMI Link-by-Link Share of Interprovincial Railway Volume 1986 (\%) . . . . . . . . . . . . . . . . . . . . . .

A 6.6 FMI Link-by-Link Share of Interprovincial Trucking Volume 1986

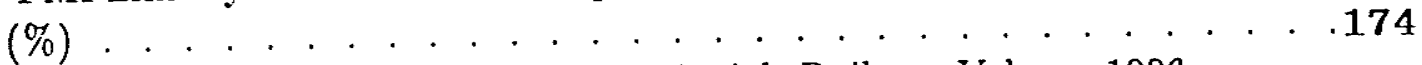

A 6.7 EPI Link-by-Link Share of Interprovincial Railway Volume 1986 (\%) . . . . . . . . . . . . . . . . . . . . . . .

A 6.8 EPI Link-by-Link Share of Interprovincial Trucking Volume 1986 (\%) 


\section{LIST OF FIGURES}

4.1 Railway vs. Trucking freight Transportation Interprovincial Tonnage . . . . . . . . . . . . . . . . . . . . . . . . . 43

4.2 Railway vs. Trucking freight Transportation Interprovincial Tonnage between Québec and Ontario . . . . . . . . . . . . . . . . . 43

4.3 Railway vs. Trucking freight Transportation Interprovincial Tonnage From Québec to Ontario.

4.4 Railway vs. Trucking freight Transportation Interprovincial Tonnage From Québec to British Columbia . . . . . . . . . . . . . . . 47

4.5 Railway vs. Trucking freight Transportation Interprovincial Tonnage From Québec to Alberta . . . . . . . . . . . . . . . . . . . . 48

4.6 Railway vs. Trucking freight Transportation Interprovincial Tonnage From Québec to the Central and Western Provinces . . . . . . . 48

4.7 Railway vs. Trucking freight. Transportation Interprovincial Tonnage From Ontario to Québec . . . . . . . . . . . . . . . . . . . . 50

4.8 Railway vs. Trucking freight Transportation Interprovincial Tonnage From Ontario to British Columbia . . . . . . . . . . . . . . . 50

4.9 Railway vs. Trucking freight Transportation Interprovincial Tonnage Fron Ontario to Saskatchewan . . . . . . . . . . . . . . . . . 51

4.10 Railway vs. Trucking freight Transportation Interprovincial Tonnage From Ontario to the Other Centra and Hestern Provinces . . . . . 51

4.11 Railway vs. Trucking freight Transportation Interprovincial Tonnage From Manitoba to Ontario . . . . . . . . . . . . . . . . . . . 53

4.12 Railway vs. Trucking freight Transportation Interprovincial Tonnage From Manitoba to Saskatchewan . . . . . . . . . . . . . . . . 53

4.13 Railway vs. Trucking freight Transportation Interprovincial Tonnage From Manitoba to Alberta . . . . . . . . . . . . . . . . . . .54

4.14 Railway vs. Trucking freight Transportation Interprovincial Tonnage From Manitoba to Québec . . . . . . . . . . . . . . . . . . .54

4.15 Railway vs. Trucking freight Transportation Interprovincial Tonnage From Saskatchewan to Ontario . . . . . . . . . . . . . . . . . 56

4.16 Railway vs. Trucking freight Transportation Interprovincial Tonnage From Saskatchewan to Québec . . . . . . . . . . . . . . . . . 56 
4.17 Railway vs. Trucking freight Transportation Interprovincial Tonnage From Saskatchewan to Alberta

4.18 Railway vs. Trucking freight Transportation Interprovincial Tonnage From Saskatchewan to the Other Central and Western Provinces

4.19 Railway vs. Trucking freight Transportation Interprovincial Tonnage From Alberta to Ontario

4.20 Railway vs. Trucking freight Transportation Interprovincial Tonnage From Alberta to Maniloba.

4.21 Railway vs. Trucking freight Transportation Interprovincial Tonnage From Alberta to Québec . . . . . . . . . . . . . . . .

4.22 Railway vs. Trucking freight Transportation Interprovincial Tonnage From Alberta to Saskatcheawn . . . . . . . . . . . . . . . . .60

4.23 Railway vs. Trucking freight Transportation Interprovincial Tonnage From British Columbia to Ontario

4.24 Railway vs. Trucking freight Transportation Interprovincial Ton-

4.25 Railway vs. Trucking freight Transportation Interprovincial Tonnage From British Columbia to Alberta

4.26 Railway vs. Trucking freight Transportation Interprovincial Tonnage From British Columbia to Saskatchewan . . .......................63

4.27 FFB\& T: Distance vs. Rate by Mode and Direction . . . . . . . . . . 65

4.28 CMI: Distance vs. Rate by Mode and Direction . . . . . . . . . . . .65

4.29 FMI: Distance vs. Rate by Mode and Direction . . . . . . . . . . . . 66

4.30 EPI: Distance vs. Rate by Mode and Direction . . . . . . . . . . . .66

5.1 FFB\& T: Maximum $R^{2}$ Improvement . . . . . . . . . . . . . . . .84

5.2 FFBdT: Mean Square Error Improvement . . . . . . . . . . . . . .84

5.3 FFB\&T: Mallow's $C_{P}$ Statistic Improvement . . . . . . . . . . . . 85

5.4 CMI: Maximum $R^{2}$ Improvement . . . . . . . . . . . . . . . . . 85

$5.5 \mathrm{CMI}$ : Mean Square Error Improvement . . . . . . . . . . . . . . 86

5.6 CMI: Mallow's $C_{P}$ Statistic Improvement . . . . . . . . . . . . . .86

5.7 FMI: Maximum $R^{2}$ Improvement . . . . . . . . . . . . . . . . . . 87

5.8 FMI: Mean Square Error Improvement . . . . . . . . . . . . . . . 87

5.9 FMI: Mallow's $C_{P}$ Statistic Improvement . . . . . . . . . . . . . . 88

5.10 EPI: Maximum $R^{2}$ Improvement . . . . . . . . . . . . . . . . . 88

5.11 EPI: Mean Square Error Improvement . . . . . . . . . . . . . . . 89

5.12 EPI: Mallow's $C_{P}$ Statistic Improvement . . . . . . . . . . . . . . . . 89

5.13 FFB\&T: Residuals Plot . . . . . . . . . . . . . . . . . . . . . .97

$5.14 \mathrm{CMI}$ : Residuals Plot. . . . . . . . . . . . . . . . . . . . . . 97

5.15 FMI: Residuals Plot . . . . . . . . . . . . . . . . . . . . . . . . 98

5.16 EPI: Residuals Plot . . . . . . . . . . . . . . . . . . . . . 98

A 5.1 FFB\&T Truck/Rail Modal Split by Commodity Section Tonnage

From Ontario to Québec 
A 5.2 FFB\&T Truck/Rail Modal Split by Commodity Section Tonnage From Ontario to Manitoba . . . . . . . . . . . . . . . . . . . . 163

A 5.3 FFB\&T Truck/Rail Modal Split by Commodity Section Tonnage From Ontario to Alberta . . . . . . . . . . . . . . . . . . . . . 164

A 5.4 FFB\&T Truck/Rail Modal Split by Commodity Section Tonnage From Ontario to British Columbia . . . . . . . . . . . . . . . . 164

A 5.5 CMI Truck/Rail Modal Split by Commodity Section Tonnage From Ontario to Québec . . . . . . . . . . . . . . . . . . . 165

A 5.6 CMI Truck/Rail Modal Split by Commodity Section Tonnage From Ontario to Manitoba . . . . . . . . . . . . . . . . . . . . 165

A 5.7 CMI Truck/Rail Modal Split by Commodity Section Tonnage From Ontario to Alberta . . . . . . . . . . . . . . . . . . . . . . 166

A 5.8 CMI Truck/Rail Modal Split by Commodity Section Tonnage From Ontario to British Columbia . . . . . . . . . . . . . . . . 166

A 5.9 FMI Truck/Rail Modal Split by Commodity Section Tonnage From Ontario to Québec . . . . . . . . . . . . . . . . 167

A 5.10 FMI Truck/Rail Modal Split by Commodity Section Tonnage From Ontario to Manitoba . . . . . . . . . . . . . . . . . . . . 167

A 5.11 FMI Truck/Rail Modal Split by Commodity Section Tonnage From Ontario to Alberta . . . . . . . . . . . . . . . . . . . . . 168

A 5.12 FMI Truck/Rail Modal Split by Commodity Section Tonnage From Ontario to British Columbia . . . . . . . . . . . . . . . . 168

A 5.13 EPI Truck/Rail Modal Split by Conmodity Section Tonnage From Ontario to Québec . . . . . . . . . . . . . . . . . . . .

A 5.14 EPI Truck/Rail Modal Split by Commodity Section Tonnage From Ontario to Manitoba . . . . . . . . . . . . . . . . . . . . . . .169

A 5.15 EPI Truck/Rail Modal Split by Commodity Section Tonnage From Ontario to Alberta . . . . . . . . . . . . . . . . . . . . . . . . . . . 1770

A 5.16 EPI Truck/Rail Modal Split by Commodity Section Tonnage From Ontario to British Columbia . . . . . . . . . . . . . . . . . . . 170 
CHAPTER 1

\section{INTRODUCTION}

\section{$1.1 \diamond$ The Research Need}

The transportation of goods across Canada by road was restricted by vehicle weight and dimension (VWD) regulations set by the various provincial and territorial govermments. Each of the ten provinces and both territories had their own sets of VWD regulations to govern the trucking industry. This fractured supervisory authority complicated the interprovincial transportation of highway freight and reduced its efficiency. It was normally necessary when transporting goods by truck to configure the shipment and vehicle to comply with the most restrictive set of regulations encountered enroute. The far reaching effects of these circumstances are apparent when it is considered that Canada is geographically linear. No routing alternatives exist to the transiting of each and every intervening jurisdiction between origin and destination.

The need for rationalized regulations to facilitate easier truck movement across Canada had long been recognized and debated by both federal and provincial levels of governments. In the 1980's, the provinces agreed to pursue new research investigating 
the effects of increasing vehicle weights and dimensions on the nation's highways. In the fall of 1986, the Roads and Transportation Association of Canada (RTAC) initiated a study to develop a methodology to examine the potential trade-offs between the economic benefits that might be achieved, and any increased costs that might result from uniform national regulation. In June $1987 \mathrm{RTAC}$ published its report, in which four scenarios of relaxed VWD regulations (labelled A through D) were examined, and trucking cost reduction predictions for each scenario were developed.

On February 12, 1988, based on RTAC recommendations, a national velicle weight and dimension agreement was approved by the Council of Transportation Ministers and a set of uniform regulations was adopted for implementation across Canada. Furthermore, that same month, the four western provinces (Alberta, British Columbia, Manitoba, and Saskatchewan) approved a regional set of regulations allowing greater weight and dimensions limits for road transport within their jurisdictions.

A need to investigate the impacts of any possible changes in VWD regulations on the structure of the Canadian freight industry and in particular, on the status quo of the railway/trucking mode split is evident. Such impacts had not been analyzed prior to the initiation of this research, and periodic literature searches undertaken during the course of this research suggest that the impcats have still not been assessed. 


\section{$1.2 \diamond$ Research Purposes and Objectives}

It is the purpose of this research to study and to better comprehend the nature of freight movement and modal choice in Canada, so that we may be better able to forecast and examine the consequences of any VWD regulatory reform on the interprovincial freight industry. In particular, it is the purpose of this research to study how reforms will affect the competitive relationship between the two principal industry components: trucking and railways. The objectives of this research are firstly to develop mathematical models for the trucking freight movement, secondly, to apply these models to predict the impacts of either mode's service characteristics changes on the freight market of both modes, and thirdly, to determine the impacts of the 1988 National and 1988 Western Agreements on the railway industry and postulate the necessary improvements in rail service characteristics to maintain its competitive position in retaining its share of the freight market under both agreements. In addition, it is the objective of this research to determine the anticipated total and link-by-link rail revenue losses due to the 1988 VWD reform. This analysis will cover the four Statistics Canada commodity sections that comprise the vast majority of interprovincial freight carried in Canada (92\% of rail tonnage, $95 \%$ of truck). These four commodity sections are "Food, feed, beverages and tobacco," (FFB\&T), "Crude materials, inedible," (CMI), "Fabricated materials, inedible," (FMI), and "End products, inedible." (EPI).

\section{$1.3 \diamond$ The Significance and Potential of this Research}

A survey of literature has revealed that little research has been done into the question of how any changes in trucking industry regulations affect rail/truck modal

shift in Canada. Specifically, no research has been done to-date to study, analyze and determine the impacts of the Canadian approved National and Western agreements on railway freight transportation. The contribution of this research comes at a time when adjustment of the trucking fleet to the newly regulated sizes and weights is in 
progress and understanding of the impacts of such reform on transportation modes is timely.

This work contributes to the research surrounding freight transportation in Canada, and will be valuable to decision makers in industry, government and the research community. For the rail industry, it can be applied to determine the necessary changes in rate policies and the future efficiency of their operations, in order to stay competitive in the freight market. Federal and provincial policy decision-makers will be able to use the techniques presented here to study the impact of any future changes in VWD regulations on the freight transportation industry.

\subsection{Thesis Organization}

Canadian Vehicle Weight \& Dimension regulations, their history and development are described and presented in Chapter 2. This is followed in Chapter 3 by a review of pertinent previous research concerning freight transportation modelling. Chapter 3 also cites some of the factors that influence the user in the process of choosing a freight mode. The data needed for the models development and calibration, its sources, collection and analysis is presented in Chapter 4. Chapter 5 discusses models development, calibration and statistical and pragmatic validation as well as the model's aptness. Chapter 6 studies how trucking regulatory reform affects the railway industry. In this chapter detailed analysis of the impacts of the VWD agreements, in terms of link-by-link railway improvements and revenue losses, are presented. Finally, Chapter 7 presents the conclusions and recommendations drawn from the research.

\section{$1.5 \diamond$ Research Achievement and Publications}

This research, on the subject of Canadian Freight Transportation, rail/truck modal split, and the effect of the newly implemented trucking weights and dimensions was begun late in 1987. The impacts of the 1988 National and Western Vehicle Weight $\&$ Dimensions (VWD) reform agreements on the railway industry have been analyzed. Most of the major finding during the course of this research have been either presented 
in conferences, published in journals, or submitted for publication.

In 1988 (May 25-27) a paper entitled "Mathematical Modelling of End Product Commodity Mode Choice" was presented at the technical sessions of the annual conference of the Canadian Society for Civil Engineering (CSCE). This paper was also published by the CSCE in the conference proceedings. The analysis presented in this paper explored the impacts of different hypothetical cases of VWD reform on the railway market share of the "end products, inedible" freight commodity section.

In 1989 (June 8-10) a paper entitled "Vehicle Weight \& Dimensions Reform and Mode Choice in Canada" was presented and published in the proceedings of that year's CSCE annual conference. A detailed exposition of information about the 1988 National and Western VWD regulations agreements was reported. The commodity classification "fabricated materials, inedible" was the subject of study in that paper. The impact of the 1988 trucking agreements on the railway industry and the linkby-link degree of expected freight shift (rail to truck) due to these agreements was presented.

Continuing the research, the April 1990 issue of Transportation Quarterly published a paper entitled "Modal Shift in Canadian Freight Transportation." This paper reported the development of a mathematical model designed to forecast the effect VWD reform induced changes in trucking service characteristics will have on the market share of freight carried by the truck and rail modes.

At the 1990 CSCE annual conference (May 16-18) a paper entitled "Impacts of Vehicle Weight \& Dimensions Regulations on Railway Freight Transportation" was presented, and published in the conference proceedings. The research embodied in that paper included the four major freight commodity sections: "food, feed, beverages and tobacco," "crude materials, inedible," "fabricated materials, inedible," and "end products, inedible." The impact of the agreements on the interprovincial movement of freight by the railway and trucking industries in Canada was studied and analyzed. Specifically, the impacts of the 1988 National and Western Agreements on the railway 
industry, and the necessary improvements in rail service characteristics to maintain its competitive position in the freight market under both agreements for each of the four commodity sections were determined. The link-by-link loss of rail revenue due to the agreements was presented for each of the four commodity sections. Furthermore, the total impact expressed in the form of railways revenue loss was also determined.

In addition to the research described above, two additional papers have been completed. A paper entitled "Interprovincial Rail/Truck Competition in The 1990's," was accepted in September 1990 for publication in the journal Transportation Planning \& Technology. Another paper entitled "Regulatory Reform and Freight Mode Choice" was also accepted for publication in the journal Transportation in March 1991.

It is indicative of the contribution of this research to note that the papers presented at the CSCE conferences stimulated a great deal of discussion, and transportation professionals in attendance showed great interest in this work. The paper published in Transportation Quarterly has also been favourably received and the journal's editors themselves expressed an interest in the work. They have inquired if further work will be submitted for consideration of publication.

Copies of the many papers presented and published have been requested and provided to a wide range of Canadian transportation professionals, government institutions and industry. 
CHAPTER 2

\section{CANADIAN VWD REGULATIONS}

Vehicle Weight and Dimension (VWD) regulations are complex. They represent an issue that involves many elements and considerations. The typical method used to describe VWD regulations are some basic rules specifying the maximum allowable dimensions and weights of vehicles and vehicle combinations. The vehicle dimension regulations govern the vehicle dimension elements, including height, width, tractor length, trailer and semi-trailer length, and the overall length of various combinations. The vehicle weight regulations, on the other hand, govern elements such as the gross vehicle weight (GVW) and the maximum allowable load carried by tire, steering axle, single axle, tandem axle, tridem axle, and combinations thereof.

While the above mentioned basic weight and dimension rules are useful, they are not fully representative of the full breadth of VWD regulations. Concerning this task, the following has been extracted from a paper by Nix and Schipizky (1984):

The typical method used to describe VWD regulations is the compilation of a chart showing such things as the "maximum allowable height" for vehicles, the "maximum allowable width", the "maximum allowable loads ... for axles of various truck combinations", and so on. Such charts are frequently published in trade magazines. Unfortunately, such "simple" description, while useful for some purposes, loses much of the complexity of actual VWD regulations. That is, VWD regulations are a complex set of definitions, rules, conditions, special 
conditions, et c... which govern everything from the "ordinary" height-widthlength aspects of trucks to the more complex problem of setting maximum allowable loads for a broad range of axle types or axle combinations.

There are many other factors that add to VWD regulation in Canada, as elsewhere. Such factors include: road classes, local authorities, seasonality, tolerance, axle spacing, axle lift, etc. The seasonality factor of the extremes of the Canadian climate is very significant in some provinces. In two seasons, loads are regulated differently than through the rest of the year. In spring, allowable axle-load reductions are required due to moisture variation and the stability of highway pavement. In the cold winter months, load premiums are sometimes allowed to take advantage of the greater weight-bearing characteristics of frozen ground.

The objectives when considering alternative regulations and the main goal in setting these regulations is to achieve an acceptably safe and efficient transport system. There are many factors that affect the setting of these regulations, some of which are infrastructure capacity (of bridges, pavement, etc.), safety needs: economics, and politics. The considerable role political factors have played in developing VWD regulations in Canada can be attributed in part to the fractured responsibility for highways, held by the several provincial and territorial governments. Twelve different sets of provincial and territorial weight and dimension regulations have evolved, and, in some cases these are compounded by multi-level road class regulations and local/ municipal regulations.

\section{$2.1 \diamond$ The Development of VWD Regulation in Canada}

The following will briefly describe the developments of weights and dimensions regulations in Canada, followed by an example of the history of regulations development process in the province of Ontario.

Relatively uniform dimensions were regulated across Canada during 1960s and begining of 1970s; the time that is considered as the start of modern regulations, Nix, et al.,(1987). An overall length of $19.8 \mathrm{~m}$, width of $2.6 \mathrm{~m}$ and height of $4.1 \mathrm{~m}$ were 
allowed. Maximum axle loads and Gross Vehicle Weight (GVW) were also made uniform. Maximum single axle loads of $8.2 \mathrm{t}$ (metric ton) and maximum tandem axle loads of $14.5 \mathrm{t}$ were established. A maximum gross vehicle weight (GVW) was set at $33.6 \mathrm{t}$. (Triple axles, now found in all provinces, were not permitted in Canada during $1970 \mathrm{~s}$, outside of the province of Ontario). There, an extra load of $18.1 \mathrm{t}$ for triple axle rigs and a maximum GVW of $52.6 \mathrm{t}$ was permitted.

The development process of VWD regulations has grown gradually with time. A review of the province of Ontario's regulations, for example, show that the first legislation to regulate vehicle weights and dimension was introduced in 1908, Csagoly and Dorton (1978). They allowed a maximum weight limit of $12.0 \mathrm{~T}$ (imperial ton). In 1923 the maximum limit was reduced to $10.0 \mathrm{~T}$, then increased to $18.0 \mathrm{~T}$ in 1924 . This was followed by occasional increase over the years until 1944 when a GVW of 36.0 T adopted, based on American Association of State Highway and Transportation Officials (AASHTO) specifications. Freight transportation demand increased rapidly during the mid-sixties and the railways were unable to respond to the increase, particularly with respect to the demands for greater speed and better accessability. A trucking GVW regulation fixing the limit at $36.0 \mathrm{~T}$ was not sufficient either, and pressure for further increases mounted. In 1966, Ontario allowed triple axles and increased GVW limits to 58.0 T.

Seeking to obtain a technical evaluation of the situation, Ontario carried out load surveys to determine the actual load carrying capacity of existing bridges. The first load survey was carried out in 1967 where the data obtained were used to establish what has come to be called the The Ontario Bridge Formula. Second and third surveys were carried out in 1971 and 1975 respectively. The Ontario Bridge Formula became the basis of Ontario's regulations, and in fact it has led, indirectly, to a series of regulations changes in other provinces.

The other Canadian provinces followed Ontario's approach by conducting bridge studies, between 1975 and 1979. The result was the determination of substantial ad- 
ditional bridge strength available for increasing vehicles weights. This has led the allowable vehicle weights to grow throughout the country. Unfortunatly, allowable weights have become increasingly different from province to province/territory, primarily due to differing considerations in each jurisdiction. The result was different levels of vehicle weight and dimension regulations set by each and every one of the ten provinces and two territories.

To appreciate the size of the problem, as of July 1987, provincial tandem axle limits show the following variation: Quebéc has the maximum limit at $20.0 \mathrm{t}$ (metric tonne), Ontario at $19.1 \mathrm{t}$, with values in the other jurisdictions ranging from $16.0 \mathrm{t}$ to 18.0 t. For maximum GVW, similar variations could be noted. British Columbia, Ontario and Yukon had the highest GVW, 63.5t, Nova Scotia the lowest, $50.0 \mathrm{t}$, and the rest of the provinces and territories had GVW limits ranging from $52.5 \mathrm{t}$ to 57.5 t. Maximum dimensions regulating truck length, width, and height show further variances. All provinces adhere to a single width standard of $2.60 \mathrm{~m}$, with the exception of the Northwest Territories, where $3.05 \mathrm{~m}$ is allowed. Height limits were uniform at $4.15 \mathrm{~m}$ for eight jurisdictions. The exceptions were Prince Edward Island $4.50 \mathrm{~m}$, the Yukon and Northwest Territories $4.20 \mathrm{~m}$ and Nova Scotia $4.12 \mathrm{~m}$. The length standard for trailer and semi-trailer included Newfoundland with the lowest limit at $12.3 \mathrm{~m}$ and three provinces and one territory with a limit of $14.65 \mathrm{~m}$. British Columbia used separate dimensions for trailer $12.5 \mathrm{~m}$ and semi-trailer $14.1 \mathrm{~m}$, and similar length variations in the case of tractor and semi-trailer. The limit ranges from a $21.4 \mathrm{~m}$ maximum in British Columbia and the Yukon, to between $19.8 \mathrm{~m}$ and $20.8 \mathrm{~m}$ in the remaining provinces. The maximum length of other combinations range from $23.0 \mathrm{~m}$ in Alberta to $19.8 \mathrm{~m}$ in other areas of the country. The extent of the diversity in VWD regulations among the provinces and territories, as of the year 1987, is illustrated in Table 2.1 .

From this lack of uniformity, the need to rationalize the vehicle weight and dimension regulation has been easy to recognize. In 1980 s the provinces agreed to 
Table 2.1 VWD Regulations in Canada (Maximum Limits)

\begin{tabular}{|c|c|c|c|c|c|c|c|}
\hline $\begin{array}{l}\text { Juris- } \\
\text { diction }\end{array}$ & $\begin{array}{l}\text { Width } \\
(\mathrm{m})\end{array}$ & $\begin{array}{l}\text { Height } \\
(\mathrm{m})\end{array}$ & $\begin{array}{c}\text { Overall } \\
\text { length }(\mathrm{m})\end{array}$ & $\begin{array}{l}\text { Max. } \\
\text { Single }\end{array}$ & $\begin{array}{l}\text { axle load } \\
\text { Tandem }\end{array}$ & $\begin{array}{l}(\mathrm{kg}) \\
\text { Tridem } \\
\end{array}$ & $\begin{array}{c}\text { G.V.W. } \\
(\mathrm{kg}) \\
\end{array}$ \\
\hline Nfld. & 2.60 & 4.15 & 21.0 & 9,000 & 18,000 & 27,000 & 52,500 \\
\hline P.E.I. & 2.60 & 4.50 & 21.0 & 9,000 & 18,000 & 27,000 & 53,500 \\
\hline N.S. & 2.60 & 4.15 & 21.0 & 9,000 & 18,000 & 27,000 & 50,000 \\
\hline N.B. & 2.60 & 4.12 & 21.0 & 9,000 & 18,000 & 27,000 & 56,500 \\
\hline Qué. & 2.60 & 4.15 & 23.0 & 10,000 & 20,000 & 30,000 & 57,500 \\
\hline Ont. & 2.60 & 4.15 & 23.0 & 10,000 & 19,100 & 28,600 & 63,500 \\
\hline Man. & 2.60 & 4.15 & 23.0 & 9,100 & 16,000 & 16,000 & 56,500 \\
\hline Sask. & 2.60 & 4.15 & 23.0 & 9,100 & 16,000 & 16,000 & 53,500 \\
\hline Alta. & 2.60 & 4.15 & 23.0 & 9,100 & 16,800 & 16,800 & 53,500 \\
\hline B.C. & 2.60 & 4.15 & 23.0 & 9,100 & 17,000 & 17,000 & 63,500 \\
\hline Yukon & 2.60 & 4.20 & 22.5 & 10,000 & 19,100 & 28,600 & 63,500 \\
\hline NW.T. & 3.0 .5 & 4.20 & 24.4 & 8,150 & 16,260 & 16,260 & 54,500 \\
\hline
\end{tabular}

(Source: Nix 1987)

establish a new research effort to investigate the effect of the increasing vehicle weights and dimensions on pavements (rather than bridges) and vehicle stability (safety). This research was conducted by the Roads and Transportation Association of Canada (RTAC) and the Canadian Conference of Motor Transport Administrators (CCMTA) (1984-1986) and has led to the signing of the National Vehicle Weight and Dimension agreement in 1988. In this study, RTAC has developed four scenarios of relaxed vehicle weights and dimensions regulation that could be implemented all over Canada. The potential trade-offs between the economics benefits and costs increase, that may result, for each scenario was examined and a corresponding trucking cost reduction was presented.

\section{$2.1 .1 \diamond 1987$ RTAC Scenarios}

In July 1987, the Roads and Transportation Association of Canada (RTAC) developed four different vehicle weight and dimension scenarios. These were based on a three year study of vehicle and pavement behavior by RTAC and the Canadian Conference of Motor Transport Administration (CCMTA). The scenarios were designed 
to meet acceptable standards of vehicle stability and control and were intended to harmonize to the maximum extent possible, VWD regulations across Canada. Each scenario consists of four different categories of vehicles with a corresponding different weights and dimensions. These four categories are:

Tractor Semitrailer,
A Train Double,
B Train Double,
C Train Double.

Detailed information of the configuration, dimensions, weights ...etc, of these four vehicle categories, as reported by the Planning Subcommittee of the joint RTAC and CCMTA Committee on Heavy Vehicle Weights and Dimensions, are presented in Appendix 1. The RTAC's trucking cost reduction for each scenario is presented in Appendix 2. The four scenarios as developed by RTAC are summarized in Table 2.2 .

\section{Table 2.2 1987 RTAC Scenarios}

\begin{tabular}{rrrrr}
\hline Scenario & A & B & C & D \\
\hline Maximum GVW (kg) & 56,500 & 63,500 & 63,500 & 62,500 \\
Tractor/Semi & 46,500 & 46,500 & 46,500 & 46,500 \\
A-Train & 53,500 & 53,500 & 53,500 & 53,500 \\
B-Train & 56,500 & 63,500 & 63,500 & 62,500 \\
C-Train & 53,500 & 53,500 & 53,500 & 53,500 \\
Maximum Overall & 23 & 23 & 25 & 25 \\
length (m) & & & & \\
Maximum Trailer Lengths (m) & & & \\
Semi-Trailer in & 18.7 & 16.8 & 18.7 & 16.2 \\
Tractor/Semi & & & & \\
Double Trailer & & & & \\
Combinations & 19.0 & 19.0 & 20.8 & A\&C: 17.2 \\
(combined trailer lengths) & $(9.5 \times 2)$ & $(9.5 \times 2)$ & $(10.4 \times 2)$ & B: 19.0 \\
\hline
\end{tabular}




\section{$2.1 .2 \diamond 1988$ National Agreement}

In February 1988, the Council of Transportation Ministers adopted a set of uniform VWD regulations to be implemented across Canada to allow the trucking industry to operate standard tractor trailer configurations through all jurisdictions. The agreement followed much debate among provincial governments, trucking associations, and the railways, and generally resembles Scenario D as proposed by RTAC in 1987. The principal change between RTAC Scenario D and the National Agreement is the restriction of maximum overall length to $23 \mathrm{~m}$ from $25 \mathrm{~m}$. This restriction also changes the allowable box lengths of the various trailer combinations. As stated in the Agreement, there some aspects intended to be accomplished by its approval. These aspects are presented in Appendix 3. The weight and dimension recommendations of the 1988 National Agreement are shown in Table 2.3.

\section{Table 2.3 1988 National Agreement}

\begin{tabular}{lcccccccc}
\hline & Height & Width & $\begin{array}{c}\text { Overall } \\
\text { Length } \\
(\mathrm{m})\end{array}$ & $\begin{array}{c}\text { Box } \\
\text { Length } \\
(\mathrm{m})\end{array}$ & $\begin{array}{c}\text { Single } \\
(\mathrm{kg})\end{array}$ & $\begin{array}{c}\text { Tandem } \\
(\mathrm{kg})\end{array}$ & $\begin{array}{c}\text { Tridem } \\
(\mathrm{kg})\end{array}$ & $\begin{array}{c}\text { G.V.W. } \\
(\mathrm{mg})\end{array}$ \\
\hline Semi & 4.15 & 2.6 & 23.0 & 14.65 & 9,100 & 17,000 & 24,000 & 46,500 \\
A-Train & 4.15 & 2.6 & 23.0 & 18.5 & 9,100 & 17,000 & N/A & 53,500 \\
B-Train & 4.15 & 2.6 & 23.0 & 20 & 9,100 & 17,000 & 23,000 & 62,500 \\
C-Train & 4.15 & 2.6 & 23.0 & 18.5 & 9,100 & 17,000 & N/A & 53,500 \\
\hline
\end{tabular}

Tire weight-dimension regulation (all configurations): $10 \mathrm{~kg} / \mathrm{mm}$.

\subsection{3॰ 1988 Western Agreement}

An agreement allowing greater weights and dimensions for road transportation among the four western provinces of Manitoba, Saskatchewan, Alberta, and British Columbia was also adopted in 1988. The four western provinces are to allow greater $B$ train weights as well as greater overall lengths and greater box lengths for all vehicle configurations. The 1988 Western Agreement is summarized in Table 2.4. 
Table 2.4 1988 Western Agreement

\begin{tabular}{lcccccccc}
\hline & Height & Width & $\begin{array}{c}\text { Overall } \\
\text { Length } \\
(\mathrm{m})\end{array}$ & $\begin{array}{c}\text { Box } \\
\text { Length } \\
(\mathrm{m})\end{array}$ & $\begin{array}{c}\text { Single } \\
(\mathrm{kg})\end{array}$ & $\begin{array}{c}\text { Tandem } \\
(\mathrm{kg})\end{array}$ & $\begin{array}{c}\text { Tridem } \\
(\mathrm{kg})\end{array}$ & $\begin{array}{c}\text { G.V.W. } \\
(\mathrm{kg})\end{array}$ \\
\hline Semi & 4.15 & 2.6 & 25.0 & 16.2 & 9,100 & 17,000 & 24,000 & 46,500 \\
A-Train & 4.15 & 2.6 & 25.0 & 20.8 & 9,100 & 17,000 & N/A & 53,500 \\
B-Train & 4.15 & 2.6 & 25.0 & 20.8 & 9,100 & 17,000 & 23,000 & 63,500 \\
C-Train & 4.15 & 2.6 & 25.0 & 20.8 & 9,100 & 17,000 & N/A & 53,500 \\
\hline
\end{tabular}

Tire weight-dimension regulation (all configurations): $10 \mathrm{~kg} / \mathrm{mm}$.

It is expected that the greater uniformity and harmony in VWD regulations across Canada achieved as a result of these agreements will result in the reduction of truck operating costs. Previously, transportation across several provincial jurisdictions complied with the most restrictive set of regulations en route. The harmonization of VWD regulations across the country enables the trucking industry to carry loads of greater weight and dimension over longer distances in fewer trips. 
CHAPTER 3

\section{FREIGHT TRANSPORTATION MODELLING REVIEW}

\section{$3.1 \diamond$ Previous Research}

In the past, transportation demand models were applied mainly to passenger demand analysis. The modelling of freight movement has not been subjected to much research until relatively recently. One of the reasons for this trend in the past was insufficient data to enable the models to be calibrated and, consequently, yield accurate results when applied to freight transportation analysis. Another reason has been due to the fact that insufficient attention has been given to the freight transportation modelling and the policies and planning associated with it. Accordingly, the awareness of the importance of freight transportation has lagged behind that of passenger transportation. This has begun to change. In the last thirty years, several studies on the subject of freight transportation modelling and mode choice have been undertaken. Among them are: Perle (1964), Mathematica (1967-1969), Baumol \& Vindo (1970), Rigaux (1971), Sloss (1971), Kullman (1973), Hartwig (1974), The Canadian Transport Commission (1976), Boyer (1977), Roberts et al. (1977), Turner (1977), Oum (1977-1979b), Levin (1978), Freidlaender \& Spady (1980), Hashemian (1981), 
Winston (1981a), Long (1984), Hall (1985), Sargious \& Tam (1988), and Abdelwahab $\&$ Sargious (1990).

\subsection{1 - Freight Modelling Approach Classification}

Modelling a freight transportation system is not a simple, straightforward task. It involves combining many parts together that interact with each other in order to generate commodity flow. The state of economy, surpluses in production, the need for consumption, mode attributes and availability, social factors, political objectives, inventory problems like space, and commodity types all play a role and have some weight in freight modelling. Different researchers from different disciplines have weighted these and other factors differently and consequently they have followed a variety of approaches in trying to understand and model freight transportation systems. Various models and modelling approaches have been suggested and developed by researchers from many disciplines in an attempt to better understand these complex systems. In scientific literature, different classifications of freight transportation models and modelling approaches have been postulated, again by different researchers from different fields. Smith (1974) reviewed the basis, problems, and empirical successes of different analytical freight transport demand models. He cited a general description, development, history and some of the advantages and disadvantages of these models. Kanafani (1983) grouped freight transportation models into three approaches: the Microeconomic Modelling approach in which the transportation activities of the carrier itself are considered as one of the inputs in the firm's transport activity (i.e. the firm is a potential user or consumer of transportation), Spatial Interaction Modelling where commodities flow from points of excess supply to points of excess demand, and the Macroeconomic approach where the economic sectors' interrelationships in the process of modelling are all considered, including the transportation sector itself.

Winston (1983) classified freight demand models based on the nature of data into aggregate (data collected for a particular mode in a national or regional level) or 
disaggregate (data collected from individual decision maker or shipper for individual shipment) models. He further points out that the strengths of disaggregate models are derived from a disaggregate perspective and therefore firmly grounded in theories of behaviour, and that they are conducive to empirical specifications which capture important decision characteristics. ${ }^{*}$ By reviewing these advantages, the superiority of the disaggregate models are clear. Theoretically this is strongly sound. However, practically this is not the case, as Winston stated himself:

Notwithstanding the conceptual strengths of disaggregate freight demand models, it is important to recognize that there are practical limitations to this type of analysis. In particular, there are considerable data requirements that must be met in order to estimate a disaggregate freight demand model. Not only does one have to obtain a sample of firms' mode choice, but one must also collect data on the characteristics of all modes (chosen and unchosen) that are included in each firm's choice set.

One may argue about the wide availability of computer software ${ }^{* *}$ which could ease the process of data collection. Winston again stated that disaggregate demand models can be difficult to estimate:

Finally, as noted by Anas (1981), models estimated from aggregate data can be more useful than models estimated from disaggregate data in the context of large-scale (regional or national) analyses of freight flows that are designed for policy analysis or practical prediction. Thus, in practice, most disaggregate freight demand studied have been limited to a fairly narrow sample population (e.g. a sample of shippers of manufactured commodities.) (Winston 1983)

Stenger \& Cunningham (1978) stated "Previous research on freight modal choice has generally taken one of the two paths: the logistics theory approach or the empirical approach." They went further and reviewed both methods. In their paper, the history of the development of each approach and its advantages and disadvantages were reviewed. They conclude that the major disadvantages of such modelling is the extensive data requirement.

* See Winston (1983) for elaboration.

** For information describing this kind of computer software, see Amemiya (1981) and Daganzo (1979) cited by Winston (1983). 


\section{$3.1 .2 \diamond \quad$ Some Widely Used Freight Models}

In this chapter, some of the widely used models in the area of freight transportation, especially those models which may in some way relate to this work, are briefly reviewed. For more specific information concerning these types of models, readers are refered to the cited references. Smith (1974), Winston (1983) and Harker (1987) are considered by the author and by other researchers as excellent sources for the state of the art and for the complete review of freight transportation modelling approaches.

\subsubsection{1 $\diamond$ Market Share Models}

This type of modelling technique examines the total imports into a region or countries and the share of that market of different exporting regions or countries. Alternatively, Market Share Models are based on examination of a region's export and the share of each of the destinations. These types of models were used by Rigaux (1971) in trying to explain fluctuations in Canadian wheat sales with respect to "distribution", "competitive" and "smaller-market" effects. While this kind of technique may lead to a good practical results, it is not however, accurate in the long run. This was concluded by Smith (1974) where he writes:

An important advantage of this type of approach is that the trade flow between any two areas is constrained by the total projected trade. This contrasts with projecting individual trade flows which could sum to an unreasonable total. The constraint effectively makes use of additional information in arriving at the flow forecasts. Market share models will often provide a practical and convenient approach for short-term forecasting in situations of stable trading patterns. However, these models essentially explain very little. They cannot cope well with wide fluctuations in inter-regional or international commodity flows and are thus unsuitable for making longer-run forecasts.

\subsubsection{2 $\diamond$ Input-Output Models}

Input-output Models were developed and used to study the inter-industry trade flows in the early 1930's by Wassily Leontief (Leontief 1951). In these models, the interaction flow among the economy sectors is recorded and used to develop a matrix 
of technical production coefficients. For a required regional demand the required inputs and outputs of each sector of the economy could be determined. These models in theory could provide information on inter-regional commodity flows and modal split and they have been used for this purpose by Chenery et al. (1953), Chenery (1956), Isard (1951), (1953) \& (1960), Leontief \& Strout (1963), Polenske (1966) \& (1967), Riefter \& Tiebout (1970) and Lee et al. (1971) among others.

In a study of the interregional trade between California and Washington by Reiefler \& Tiebout (1970), an input-output model was developed. The authors identified the inter-industry and interregional linkages between the two states' economies. They concluded that the model was a useful tool in predicting the interaction between these economies only in the short-run. Over longer periods of time any attempt to use the model in prediction was not encouraging due to the variablity of trading patterns. As with other models, the requirement of extensive data, its unavailability and its incompatibility between regions, limited the usefulness of this kind of model.

\subsubsection{3 $\diamond$ Inventory-Theoretic Mode Choice Model}

Inventory-Theoretic Mode Choice modelling is based on the principle of profit maximization (i.e. for any given movement the least transportation cost will be selected). A drawback of this model is that an industry may break into the market and

experience some losses in the short-run. However, in the longer term it may regain its losses and experience a major profit. This drawback of the model is quiet evident. It only recognizes short-run profit maximization. Again the major problem of developing this model is the data requirement. Smith (1974) pointed out that the data requirement to calibrate this kind of model is quite unrealistic. This data requirement problem was also mentioned by the Mathematica team who first developed this kind of model. Even if the required data were available, in terms of commodity type and tonnage, accurate information on total travel time and accurate cost data must be available. It has been concluded by Smith that data to calibrate this model cannot 
be gathered, which severly impairs the use of Inventory-Theoretic models.

\subsubsection{4॰ Gravity Type Models}

Another type of model is the Gravity type model. The name is derived from an analogy with Newtonian physics. Gravity models have a long history as passenger transportation planning tools, used to balance origin/destination trips so that the predicted zone-to-zone flows are consistent with the trips generated at each origin and the trips terminating at each destination. In transportation terminology, the model states that the flow between origin and destination depends on the strength of the attractive forces (production and consumption) and the significance of the frictional factor (such as mode service attributes and/or the distance or cost) between the origins and destinations.

The gravity model for freight movements is typically expressed in the following form:

$$
V_{g i j}=\frac{P_{g i} \times C_{g i}}{R_{g i j}^{c}}
$$

$V_{g i j}=$ demand for transport of commodity $g$ from origin $i$ to destination $j$.

$P_{g i}=$ production of commodity $g$ at region $i$.

$C_{g j}=$ consumption of commodity $g$ at region $j$.

$R_{g i j}=$ cost of transport for commodity $g$ from $i$ to $j$.

$c=$ parameter (empirically calibrated).

Gravity model types and variations have been surveyed and documented in the literature by Carrothers (1956) and Olsson (1965). These models have been extensively used in passenger travel analysis and less extensive in freight flow studies. Heggie (1972) cited some results of a study conducted by the British Ministry of Transport in 1966, where the gravity model was applied to estimate the freight movement of some U.K. ports. In this study the estimation error was fairly substantial, so that Heggie concluded "That such models are unsuitable for most practical forecasting purposes." 


\subsubsection{Econometric Abstract Mode Models}

The Econometric Abstract Mode Model is one type of gravity model, based on the hypothesis that the demand for commodity flows between two regions is derived directly from the economical measures of both regions. The origin is the region of excess supply and the destination is the region of excess demand. The name Econometric Abstract Mode model derives from the inclusion of economy measures at origin and destination and the model's capability to include attributes of all modes involved in the transportation system. The econometric abstract mode model was first developed by Quandt \& Baumol (1966) to model intercity passenger transportation. As far as freight transportation is considered, Perle (1965) and Mathematica $(1967,1969)$ proposed models for freight studies analogous to the Quandt \& Baumol model. While the Perle model was calibrated using data for five commodity groups and nine origin/ destination regions in the U.S., the Mathematica model was not calibrated.

In general, research in the area of econometric freight transportation modelling can be classified into three categories: supply-side models (focused on the issue of describing the production of freight transportation service), demand side models (attempting to explain the demand for transportation as function of a mode's attributes, rates and level of service), and integrated models (combining supply and demand). Most of the work done utilizing econometric abstract mode models has been intended to study policy issues and their impacts, and not to generate detailed freight routing predictions. Friedlaender \& Spady (1980) applied aggregate econometric models in order to calculate the competitive equilibrium rate for the purpose of evaluating regulatory reform. They concluded that their model was not accurate in predicting but it was a useful tool in determining competitive equilibrium. This in turn was a useful benchmark for use in policy analysis. Harker (1987) reviewed the econometric approach to freight transportation:

The major impetus for the development of these models was not to make predictions about the freight transportation system, but rather to understand the productions/cost characteristics of the industry. These models, though not 
meant for direct use as a predictive tool, are useful in developing such tools in that they shed light upon the definition of potential equilibrium industry structures and output vectors

After careful consideration of the advantages and disadvantages of different models, Smith (1974) recommended the use of the abstract mode modelling approach. He wrote that:

In case of poor data, and particularly where the commodity groups are fairly aggregated, the use of one type of gravity model or of an abstract-mode model may be the best that can be done.

\subsection{3 $\diamond$ Canadian Freight Transportation Studies}

\subsubsection{1 $\diamond$ CTC Model}

In 1976 the Canadian Transport Commission published its report (No. ESAB76-16-1) presenting a medium-term forecasting model for the demand for freight transport in Canada. The model to some extent falls within the econometric abstract mode models classification. It is multi-modal in structure, containing three modes, rail, truck and marine transportation. The inclusion of the three modes was only in the model formulation and specification however. With regard to parameter estimation, the model was only calibrated for two modes: rail and marine.

The model's structure is not complicated, and quite simple to understand and use. It stated that the demand for transport of commodity $g$ from origin $i$ to destination $j$ for a given mode $m$ at time $t$ will vary directly with production of the commodity at the origin $i$, directly with consumption of the commodity at the destination $j$, and inversely with the cost of transport between the origin and destination. The formulation of the model is as follows: 


$$
\begin{aligned}
V_{g i j m t}= & \alpha_{g i j m}+\beta_{g i m} \rho_{g i t}-\bar{\beta}_{g i m} C_{g i t}+\gamma_{g j m} C_{g j m} \\
& -\bar{\gamma}_{g j m} \rho_{g j t}+\delta_{g m} R_{g i j m t}+\sum_{\bar{i}, \bar{j}, \bar{m}} \psi_{g i j m} V_{g i \bar{j} \bar{m} t}
\end{aligned}
$$

where

$$
\begin{aligned}
V_{g i j m t}= & \text { demand of transport of commodity } g \text { from } i \text { to } j \text { by mode } m \text { at } \\
& \text { time } t . \\
\rho_{g i t}= & \text { production of commodity } g \text { in zone } i \text { at time } t . \\
C_{g i t}= & \text { consumption of commodity } g \text { in zone } i \text { at time } t . \\
R_{g i j m t}= & \text { cost of transporting commodity } g \text { from } i \text { to } j \text { by mode } m \text { at time } \\
& t . \\
\sum_{\bar{i}, \bar{j}, \bar{m}}= & \sum_{g=1}^{G} \sum_{i=1}^{I} \sum_{j=1}^{J} M_{g i j}=\text { all links that are complementary or com- } \\
\alpha, \beta, \bar{\beta}, \gamma, \bar{\gamma}, \delta, \psi= & \text { empirically determined parameters. }
\end{aligned}
$$

It should be realized that the collective term $\left[\beta_{g i m} \rho_{g i t}-\bar{\beta}_{g i m} C_{g i t}\right]$ represents excess production at zone $i$. Similarly, the collective term $\left[\gamma_{g j m} C_{g j m}-\bar{\gamma}_{g j m} \rho_{g j t}\right]$ represents excess consumption at zone $j$. The cost component $R_{g i j m t}$ is a function of the level of competition between modes. It in turn affects the amount of commodity $g$ moved and the choice of a transport mode.

The model was constructed and developed to be used to predict and analyze national and international Canadian freight movement. Data from different sources (covering the years 1974 and earlier) for the two modes of freight transport (rail and marine) was collected. Accordingly, two different data bases were constructed: origin/ destination freight movement by different modes and for different links, and variables representing economic activity, both in North America and overseas. The North American continent was divided into six regions and the economic factors and quantity of tonnage included represent these broad regions. This results in heterogeneous data and inaccurate results. The regions used were: the Atlantic provinces, Quebec, Ontario, the Prairie provinces, British Columbia, and the United States. The rest of the world was divided into nine regions: the United Kingdom, the rest of the European Economic Community, other Western European countries, Eastern Europe and the Soviet Union, Japan, the rest of Asia, Australia and New Zealand, Africa, 
and Latin America.

In terms of model service attributes, the CTC model included only freight rate. Travel time was recommended in this report for inclusion in future transportation modelling processes, but was not included in their published model. With today's rapid changes in technology, progress towards faster and more efficient freight movement is being made. Performance improvement could take place either through faster travelling speed (by inclusion of new lanes, new routings and/or the production of faster vehicles for example) and/or better handling efficiency (such examples as: more efficient terminals, advancement in locating and handling the intermodal shipments, and the use of new more efficient equipment). Therefore, the inclusion of a travel time factor in a freight model is quite important, especially when determining modal split. The CTC model estimated only rail/marine parameters to study the modal split, however trucking in Canada comprises a large share of freight movement. Most commodities in Canada move by truck and/or rail. The truck share of some commodities ranges as high as 40 to $60 \%$ or more. Including truck freight movement and estimating truck parameters in the model would have facilitated later analysis to determine the modal split and to predict freight movement. As reported previously for other models, the greatest disadvantage of the CTC model is its massive data requirement. The model was not tested because of this reason, as stated in the report.

Finally, the CTC authors concluded that their model requires the estimation of a huge number of parameters. They added that:

Although we have estimated these, every attempt should be made to get along with fewer parameters. there are two reasons. First, the amount of data needed to estimate the general model leaves us with few degrees of freedom to experiment with; for example, it is difficult to split our data into two parts, use one part to build the model, and the other part to test it. Second, the massive number of parameters masks, and thus makes more difficult to comprehend, the structure of the demand for transportation; models should be as parsimonious as possible if we expect to learn anything from them. 


\subsubsection{2॰ Oum Model}

Oum (1979) developed an aggregate freight transportation demand model. This model falls in the category of econometric abstract demand-side models. Oum's model assumes that the producing firms are profit maximizers and that transportation is a factor in their production processes. Assuming perfect competition in this (transportation) market, the demand for transportation can be found via Shepard's Lemma (derivative property). The demand function in his model relies on the assumed cost function of the producing firm. Oum's general unit cost function (he referred to this function as the general model) is of the following form:

$$
U C_{l}=C\left(P_{l}, Z_{l}, D_{l}\right) \quad l=1,2,3, \ldots, L
$$

where

$U C_{l}=$ average freight cost per ton-mile on link $l$

$P_{l}=M \times 1$ vector of prices of $M$ modes on link $l$

$Z_{l}=M \times N$ matrix of quality attributes of service of $M$ modes on link $l$

$D_{l}=$ distance of link $l$ in miles.

Data for two freight transportation modes, rail and truck, was obtained from the Canadian Freight Transportation Model (CFTM) data base for the year 1970. Eight different commodity groups representing a wide variety of commodity attributes were used. For each commodity group, the distance of each link, the total tonnage moved by each mode on each link, and the quality of service attributes for each mode were obtained. The quality of service attributes employed in this study are the speed and reliability of alternative modes. Average transit time was used to generate "average speed in miles per day" (proportional to the inverse of average transit time) and "reliability" (reliability of transit time determined as the reciprocal of the coefficient of variation in transit time distribution). Rail transit times were obtained from $\mathrm{CN}$ and CP for bulk and non-bulk commodities, for actual car movements during October 1970 for CN and March 1971 for CP. For those links with no recorded data, Oum developed regression models to estimate both the average transit time and standard 
deviation of railway transit time. These equations do not have good explanatory powers, $R^{2}$ values are relatively low, 0.50 and 0.37 respectively. Transit times were calculated from regression equations developed using Turner's (1975) data. The latter equations have better explanatory powers, $R^{2}$ values are 0.94 and 0.72 for the truck transit time and its standard deviation respectively.

In addition to the general unit cost function presented above, three alternative models, link and commodity specific models were developed (model A, model B and model C). These three models are similar in that each cost function has the natural logarithm of the average transportation cost per ton-mile as its dependent variable. For each model a set of demand functions (one for rail and the other for truck) were estimated, each of which contained the modal expenditure share (revenue share from the carrier's viewpoint) as its dependent variable. The general model (model A) has 28 parameters to estimate. The specification of this model is based on the shippers selection, which is derived from both the quantity and quality of the modes. The model B specification is based on the shippers selection by quantity of only the modes used. This model has only nine parameters to estimate. The third model (model C) is based on the assumption that the competing modes were differentiated exclusively in the shipper's view by their attributes (i.e. the model aggregaters are assumed to have an identical set of parameters). This model has the least number of parameters to estimate, seven.

Oum utilized the hypothesis testing to identify which of the three alternative models was best overall. He found that the model with the quality variables (speed and time reliability), model A, was the best fit for the relatively high-value (per ton) commodities whereas the model without the quality variables (model B) was the best fit for the relatively low-value (per ton) commodities. Model $\mathrm{C}$ was not chosen for any of the commodity groups. Oum concluded that speed and reliability do influence the shippers of high-value products, whereas for low-value industrial raw material they do not influence the shippers in making their mode selection. He added that 
for low-value commodities competition between modes is high for short distances, with rail dominating over medium and longer distances. On the other hand, for high value-commodities the competition between the two modes was likely to take place over short and medium distances.

\section{$3.2 \diamond$ Factors Affecting Users' Mode Choice}

There are many factors that can influence users in the process of choosing a freight mode. Some factors weight more than others, and their relative importance differs from one shipper to another and from one commodity to another. The carrier can improve his market share by being sensitive to these factors, his service attributes and customers' needs. Some of these factors can be quantified and determined while others cannot. Identification of the factors which can influence the decision of the user whether to ship via one mode or another is necessary in the course of the freight

modelling process. Knowledge of such factors is necessary because they constitute some of the explanatory variables in the freight model. In the literature these factors have been generally classified into three broad range groups: modal level of service attributes, commodity attributes and receiver and shipper attributes.

Modal level of service attributes are the different characteristics of competing modes which motivate or influence the user to ship his commodity by one mode or another. Cost to the user (rate), door-to-door travel time, distance, service frequency, and reliability among other factors, are of some relative importance in influencing shippers, receivers and other decision makers. These factors have been the most. commonly included in the existing freight mode choice models. Watson et al. 1974 documented an attempt to find a specification of the factors which influence the shipper mode choice. In addition to rate, travel time, et cetera, they pointed out other factors such as: shipment weight, accessibility of the shipper and receiver to the mode, packaging requirements, loss and damage for each mode, and special services offered by various carriers. Although these factors have been recognized and reported, 


$$
-28-
$$

most of them have not been included because of the need for accurate and extensive data.

The characteristics of the commodity to be shipped itself often determines the mode of transport used. Such characteristics include: commodity value, density, and perishability. In examining the factors that influence mode choice decisions of freight shipment in Atlantic Provinces of Canada, Wilson et al. (1986) concluded that cooperation between shipper and carrier personnel has some influence in the decision to use trucking, and the shipment tracing capability of carriers is one of the important factors influencing the choice of rail. They added that commodity types such as crude materials (needing a cheaper bulk transportation mode), end products (where inventory costs necessitate faster transportation) or perishables (which lose value rapidly with time) influence decision makers.

Similar findings were also concluded in earlier studies by Church (1971) and Turner (1975). Turner studied freight mode selection in Canada. His study was conducted in 1975 for the Canadian Institute of Guided Ground Transport. In his study, Turner developed two types of models, logit and regression models of freight mode tonnage share between origin/destination pairs. Each model was estimated separately for thirteen different Canadian Freight Transport Model (CFTM) commodities from a 1970 data base. Different models were estimated for different links depending upon the existing competing modes: rail, truck and marine or rail and truck only. Turner cited the relative importance of each of the mode and shipment characteristics to the freight mode selection. He concluded that freight rate, distance and weight are the variables that most strongly affect the mode choice decision. He added that transit time is important for some but not all commodities.

Long (1984) conducted a study towards the same goal Turner pursued, determining the factors affecting freight mode selection in Canada. Similar to Turner's models, Long estimated both logit and regression models for three different aggregated commodity groups using the CFTM data base for the years 1974 and 1978 . 
Two freight transport modes were included in this study, rail and truck. He concluded that although the estimated models do not have good explanatory power, they lead to several findings about Canadian freight mode share determination. Again similar to Turner's findings, Long cited freight rate, transit time and distance to be highly significant in determining mode share for rail and truck. He added that these factors affect different commodity types differently.

A study to identify the effect of different commodity properties and shipping characteristics on modal choice decisions in Canada was conducted by Sargious \& Tam (1988). Seven commodity groups having substantial movement either by rail or truck were included in the study. The elasticity of mode choice of these commodity groups with respect to travel time and rate were determined. They concluded that travel time and rate affect the mode choice however the effects of these attributes is very sensitive to the type of commodity and shipping distance. From this it appears that substantial emphasis should be placed on commodity types in the process of freight mode choice modelling. This could be achicved either by including commodity attributes as independent variables or by grouping the different commodities into groups as homogenous as possible, then developing different models for each commodity grouping. It is this latter approach that is adopted for this research.

Receiver and shipper characteristics are of some importance in determining mode choice. Warehousing costs, the risk of stockout costs and plant size, for example, are factors that influence mode choice. Availability of the mode, for instance whether a rail branch or spur exists or when the location of production or consumption is captive to only one mode, is also strongly determinant in transport mode choice.

Shipment size is another important factor that has been included in the literature of freight modelling by several authors. Hall (1985) examines the dependence between freight mode and shipment size. His study concentrated on the shipper's behaviour when making a simultaneous decision to minimize transportation and inventory cost. He concluded 
OPTIMAL freight transportation mode depends on production rate and inventory holding cost. Transportation modes which consolidate over many origin and destinations are least expensive for small production rates. Transportation modes which do not consolidate are least expensive for large productions rates.

Optimal shipment size is a discontinuous function of production rate. Thus, certain shipment size ranges are never optimal. These ranges do not depend on item value or inventory carrying charge, provided that intransit inventory cost is negligible and capacity does not constrain shipment size.

Work by Morton (1972), Rakowski (1973), Breitenbach (1973) and Roth (1977) was reviewed by Stenger \& Cunningham (1978). They conclude that these studies require extensive specific data, and even when shipment size data is available, it is available in a very broad range, making its inclusion difficult. There are other factors which are not related to modal level of service but do affect the mode selection process. Factors such as government regulations and long-term freight transportation contracts with a designated carriers.

All of the previously discussed factors either individually or collectively play a role in determining mode choice. With close examination it appears that most if not all of these factors are carried in some way by the cost factor. Cost is in part comprised of most of these factors, either directly or indirectly. The cost is related directly to travelling cost by a transport mode or indirectly as a terminal cost. In the latter case the cost is related to inventory costs, loading and unloading costs, and loss and damage costs. The higher the value of the commodity, the higher the inventory cost. To minimize inventory cost in general, a reliable and faster travel time is required. This will not only minimize the inventory cost but will protect the receiver against the stockout costs to some degree.

In summary, cost and travel time are of a great importance in determining mode choice and should be included in any freight transportation demand and mode choice modelling process. Shipping distance and commodity type, as discussed in the literature, are also of great importance to mode choice selection. The limitation to including other apparently important factors in the modelling development process, as discussed earlier, is principally the requirement for accurate and extensive data 
which in most cases unavailable.

\section{$3.3 \circ$ Guiding Principles From the Literature}

The preceding literature review in this chapter demonstrates that there are a variety of freight transportation modelling approaches. These approaches have been developed by different researchers from different disciplines and classified into different categories. It also becomes apparent that there are numerous factors influencing users making the mode choice decisions. Some of these can be quantified while others cannot. The rigorous data requirements for modelling process and the high cost and time consuming collection, or inavailability and inaccuracy of available data, make most of the reported models of limited use.

The advantages of aggregate data models over disaggregate models, in terms of usefulness, in studying the wider range of transportation movement is clearly indicaied from the literature. Models of aggregate nature appear to be useful in studying situations such as the impacts of introducing a national policy or reform of a transportation mode on the inter-modal split and on the economy as a whole. From the review conducted it is clear that the econometric abstract mode modelling technique is of great use in studying the impacts of newly implemented policy and regulations on the user's mode choice and consequently on the regional and national economy. The use of such technique is also recommended in the literature for situations of poor data, and particularly when data is reasonably grouped into commodity sections.

The freight modelling and mode choice literature also indicates that among the factors that influence the user to choose the freight mode are freight rate (cost to the user), travel time, distance, and commodity nature. These factors are found, by different studies carried by different researchers, to be the most influential on the

user. Some of these factors have been included in Oum's Canadian freight transportation modelling study, particularly travel time (as a reliability function) and distance. Freight rate was not included in Oum's model. Conversely, freight rate was included 
in the CTC model as a mode attribute that influenced the user's view towards different modes' usefulness while travel time was not included. The latter is an important factor, as reported in the literature, in determining freight movement and modal split. Some commodities (for example, perishable commodities) may not move from one region to an other in the absence of fast mode (i.e. they are travel time dependent). The advancing technological environment is however portending faster freight movement from point of pick-up through to point of delivery, and the importance of travel time to the shipper and therefore to freight modelling can only grow.

Improvement in highway infrastructure, including new and wider lanes, additional short-cut or pass-by lanes, better road maintenance, new and higher capacity bridges, implementation of more efficient terminal handling facilities, and an introduction of new VWD regulations will result reductions in truck mode shipping expenses and improvements in door-to-door travel time. These improvements will be reflected in the costs charged to the user, in turn influencing the user's decision to ship which commodity by which mode: The derivative observation to be made from this is that the inclusion of cost to the user and door-to-door travel time is both an important and realistic contribution to developing a model to study intermodal split, and particularly in conducting analysis of the impacts of new transportation mode regulation on the modal split.

In this research aggregate models for interprovincial freight movement in $\mathrm{Ca}$ nada are developed. Cost to the user, door-to-door travel time, origin/destination distance, and different commodity groups, among other factors, will be analyzed and included in the model development process. The data applied is the most recent available (1983-1987) and it is aggregated under four commodity sections supplied by Statistics Canada. These models will then be used to predict and analyze the impacts of newly implemented Vehicle Weight and Dimension regulations on the rail/truck modal split across Canada. 


\section{CHAPTER 4}

\section{DATA COLLECTION \& ANALYSIS}

In order to determine modal shift from trucking volume, the model development process involved the use of origin/destination socio-economic indicators and railway and trucking service characteristiss. This information was collected for the origin/destination (O-D) set defined as the six central and western provinces of Canada: Québec, Ontario, Manitoba, Saskatchewan, Alberta, and British Columbia. As discussed earlier, the contribution of other factors to the modelling process was assessed. Reliability, intermarket relationships, and government policy intervention are not included in this study. The exclusion of such factors was unavoidable because this study is not based on disaggregate data, but on aggregate movement statistics. In this data context, such detailed information on the shippers decision is not available.

Origin/destination indicators were selected to reflect the generative and attractive capacity of the social and economic conditions of each province. These variables included: population, per capita income, market index, and industrial index. Service characteristics of the two modes were represented by travel time and user cost.

Transportation flourishes not for its own ends, but to fulfill demand generated by socio-economic activity in the market served. Goods of various types move from 
points of production to points of consumption, and the levels of production and consumption fluctuate within the marketplace's capacity for each. Measuring these capacities, and their contribution to freight traffic requires quantifiable assessments of socio-economic factors at both ends of the transportation service. For the four freight commodity sections, origin and destination factors selected were measures of market activity and industrial activity, and population and mean personal wealth. Using these variables, mathematical models were developed and calibrated against five sets of published freight volume statistics.

\section{$4.1 \odot$ Source of Data}

Data on railway and trucking freight movement was obtained from Statistics Canada publications 53-224 (For-Hire Trucking Survey) for 1983, 53-222 (Trucking in Canada) for 1984, and 52-214 (Railway Transport Commodity Origin and Destination Statistics) for both 1983 and 1984. Data for the years 1985 through 1987 was obtained directly from Statistics Canada for both modes.

Origin/destination socio-economic indicators were obtained from Statistics Canada and respective years of the Financial Post's Canadian Markets. These included the Financial Post's market index and industrial index statistics, which are defined by the source as follows:

Market Index: "Average retail sales per capita in each area as measured against the national average retail sales per capita. This index gives an indication of the relative retail sales power of each market."1 and

Industrial Index: "Total value added per capita in each area as measured against the national total value added per capita." ${ }^{2}$ This index gives an indication of the relative industrial productivity of each province.

Annually, Statistics Canada publishes summary reports of commodity movement among provinces and territories. Motor transport freight is classified according

\footnotetext{
1 Financial Post, 1988. Canadian Markets, p. 594.

2 Financial Post, 1988, Canadian Markets, p. 593.
} 
to the Standard Commodity Classification system (SCC), as outlined in the $S C C$ Manual (catalogue 12-502). The major railways report movements classified according to the Standard Transportation Commodity Code (STCC). These two systems are different in classifying freight. While the classifications are incompatible at the individual commodity level, the tabulated data in both cases is aggregated into comparable "commodity sections" (general groupings).

The annual For-Hire Trucking Survey (until 1984) reported by interprovincial link each commodity section including: revenues, tonnage, number of shipments, and tonne-kilometers hauled. The surveyed population consists of all shipments carried by for-hire trucking firms with revenues of $\$ 100,000$ or more per year. These operators are grouped into three classes: Class I (annual revenues over $\$ 2.9$ million); Class II (revenues between $\$ 350,000$ and $\$ 2.9$ million); and Class III (revenues between $\$ 100,000$ and $\$ 350,000$ yearly). Since 1984 , the annual Trucking in Canada has not contained such reports, and thus information was obtained directly from Statistics Canada.

The Railway Transport Commodity Origin and Destination Statistics report tabulates annual tonnage and revenues for each interprovincial link for each of the commodity sections. The surveyed railways are grouped into two classes: Class I (Canadian National and Canadian Pacific); and Class II (all other railways). In 1987, Class I railways carried 76 percent of all railway tonnage moved in Canada; which generated about $85 \%$ of the total railway industry revenue.

This study focuses exclusively on the effects of VWD reform on interprovincial freight movement. As such, data from Canada's Class II railways (all of which operate intraprovincially) and Class III trucking companies (which concentrate on local, largely intraprovincial hauling) has been excluded. In 1987 for example, the freight tonnage carried intraprovincially by Class III trucking constituted $94.5 \%$ of Class III tonnage, leaving only $5.5 \%$ of Class III tonnage to be carried interprovincially. The intraprovincial freight carried by this class for the same year generated $90 \%$ of its rev- 
enue. Only $10 \%$ of Class III revenues were generated from interprovincial shipments. Trucking travel times were obtained through discussion and consultation with representatives of two national carriers. Responses received reported door-to-door service including transit time and terminal handling time. Rail transit times were obtained from published Canadian National Railways schedules. To derive door-todoor travel time, estimated terminal times were added to the transit time. Terminal times from one-half to three days were used depending upon commodity type. The estimated door-to-door travel time was then verified and validated through consultations with the railways respective department. For the purposes of determining interprovincial travel distances and times, the major city in each province was used. In the cases of Alberta and Saskatchewan, where two major cities exist, the city on the Canadian National mainline was chosen so as to coordinate with the use of the CN schedule. Distances to and from Edmonton were used for Alberta and to and from Saskatoon were used for Saskatchewan.

A principal objective in choosing a source for freight rates was that the resulting data reflect the cost of shipping as incurred by the user (the customer). Industry pricing principles, prefered customer policies, and a wide variety of incident-specific variations in tariffs were avoided by selecting data that reflected mean net pricing. The user makes his modal choice decision based on the net rate paid to the carrier, not the internal costs incurred by the carrier in providing service.

Net rates for freight movement by truck and rail were generated from the total revenue and tonnage published in the previously mentioned reports, and calculated as the ratio of revenue per tonne $(\$ / t)$. The estimated rail rates were evaluated in consultation with the CN Department of Cost and Profit Analysis headquartered in Montréal. The For Hire Trucking Survey (until 1984) and data supplied directly by Statistics Canada (since 1985) contain values labelled "revenue per tonne" derived from the average shipment size of Statistics Canada's sample truck population. However, these values proved highly divergent from the calculated revenue per tonne for 
trucking. Since no similar statistic was reported for rail movements and the identical method of derivation for the calculated statistic supported its use in comparison with the calculated rail statistic, the reported "revenue per tonne" was not used.

As previously discussed, data for the user cost variables was derived from secondary sources. Specifically, the Statistics Canada reported "revenue" values for each O-D link for each mode were divided by corresponding "tonnage" statistics to derive the revenue-per-tonne variable initially used in the model research. While this process yielded reliable and significant information for the trucking industry, similarly derived data for railways was not useful. These data were instead used in a regression analysis to derive a distance dependent function for railway user costs. Namely:

$$
C_{R}=f\left(D_{o d}\right)
$$

$$
\begin{aligned}
C_{R}= & \text { users cost by rail, in } \$ / \text { tonne } \\
D_{\text {od }}= & \text { distance between the principal city of the origin and destination province, } \\
& \text { in } \mathrm{km} .
\end{aligned}
$$

The principal cities of each province were the same as those used to establish trucking and railway travel times, described earlier.

\section{$4.2 \diamond$ Data Organization}

Statistics Canada railway and motor transport data is organized around "commodity sections", seven for railways and six for trucks as shown in Table 4.1 This study focuses exclusively on sections 2 through 5: "Food, feed, beverages and tobacco" (FFB\&T) which comprised 16.7 and 26.0 percent of the 1987 interprovincial freight volume moved by Class I \& II for-hire trucking and Class I railways respectively, "Crude materials, inedible" (CMI) which comprised 12.9 and 47.0 percent respectively, "Fabricated materials, inedible" (FMI) which comprised 52.5 and 25.0 percent respectively, and "End products, inedible" (EPI) which comprised 17.9 and 2.0 percent respectively. In revenue terms, FFB\&T comprised 16.2 and 28.0 percent, 
of 1987 interprovincial trucking and railway revenue respectively, CMI comprised 3.7 and 29.0 percent respectively, FMI comprised 35.8 and 33.0 percent respectively, and EPI comprised 44.3 and 10.0 percent respectively. Competition between the trucking and railway modes is high within these commodity sections at present and is likely to increase upon the full fleet adjustment to the new VWD regulations.

\section{Table 4.1 Commodity Sections}

\begin{tabular}{|c|c|}
\hline Railways & Trucks \\
\hline 1. Live animals (car load) & 1. Live animals \\
\hline $\begin{array}{l}\text { 2. Food, feed, beverages and } \\
\text { tobacco (car load) }\end{array}$ & $\begin{array}{l}\text { 2. Food, feed, beverages and } \\
\text { tobacco }\end{array}$ \\
\hline $\begin{array}{l}\text { 3. Crude materials, inedible } \\
\text { (car load) }\end{array}$ & 3. Crude materials, inedible \\
\hline $\begin{array}{l}\text { 4. Fabricated materials, } \\
\text { inedible (car load) }\end{array}$ & $\begin{array}{l}\text { 4. Fabricated materials, } \\
\text { inedible }\end{array}$ \\
\hline $\begin{array}{l}\text { 5. End products, inedible } \\
\text { (car load) }\end{array}$ & 5. End products, inedible \\
\hline $\begin{array}{l}\text { 6. Special types of traffic } \\
\text { (car load) }\end{array}$ & $\begin{array}{l}\text { 6. General or unclassified } \\
\text { freight }\end{array}$ \\
\hline 7. Non-carload freight & \\
\hline
\end{tabular}

For the four commodity sections, models were calibrated using $1983,1984,1985$, 1986,1987 , and combined 1983-87 data for thirty interprovincial O-D pairs among the six central and western provinces. The tonnage moved between these six provinces represented approximately 82 and 87 percent of the total interprovincial tonnage moved in Canada by rail and truck respectively. Movements involving the Atlantic provinces were not included in order to eliminate competition between waterborne modes of shipping, and movements involving the territories were excluded because of their small volume and the absence of a rail link in the Yukon Territory.

Intraprovincial movements were excluded for several logical and pragmatic reasons, namely: (1) VWD reform primarily affects interprovincial freight movement; (2) the non-competitive nature of the short haul market (in which railways are unable 
to offer service comparable to highway transport); and (3) intraprovincial data for certain tabulations is incompatible from one year to the next (movements by Class II railways and Class III trucking companies are not tabulated in the same format in some Statistics Canada reports).

\section{$4.3 \diamond$ Rail/Truck Competition \& Modal Split}

The subject of freight modal split in general and competition between the rail and truck modes in particular has recieved substantial attention of late. In the decade since 1978 the Canadian trucking industry has experienced a $66 \%$ increase in the amount of tonnage it has transported interprovincially. During this same period the railway industry has experienced only a $28 \%$ increase in tonnage for movements over the same links. Figure 4.1 depicts the interprovincial tonnage hauled for both railway and trucking modes. There is, however, a perception held by some that the use of more productive truck weight and dimensions (relaxing VWD regulations) does not divert traffic from rail to truck. This perception can be astributed to the belief that each mode has its own speciality and ability to carry or move certain types of commodity over certain distance ranges.

This argument may appear cogent at first glance, however the shift from one mode to another over the years is quite evident from the gathered data and the literature. In this context Statistics Canada (Rail in Canada, 1987) writes:

despite certain differences in the type of freight transported there exists a notable level of competition between the rail and truck modes

Dealing with the same argument Pearson (1989) writes:

In recent years the competitive position of the trucking industry relative to the railways has improved substantially. In spite of the fact that rail is ideally suited to transportation of bulk commodities, trucking continues to penetrate markets traditionally held exclusively by rail service. For example, some grain shipments are now being made by truck, due in part to liberal weight and dimension allowances and steadily increasing rail costs. Recent costing studies by the railways have indicated that they have difficulty competing for hauls less than $1100 \mathrm{~km}$. 
In Economics of Truck Sizes and Weights in Canada: Final Report (RTAC

1987) RTAC reported that:

there is a substantial amount of railway traffic which is vulnerable to truck competition. If trucking costs and rates are reduced as a result of new regulations allowing greater truck productivity, some of this rail traffic will be divertd to the truck mode; in addition, railway revenues on other traffic which retained will be lower because of reductions in rates necessary to remain competitive with the trucking mode.

The same report carried the concerns of the railway industry itself, stating that:

The two major Canadian railways, $\mathrm{CP}$ and $\mathrm{CN}$, are very concerned with the potential impacts of any relaxation in velhicle weights and dimensions regulations. They are concerned with three possible impacts:

a loss of traffic, due to lower trucking costs and rates;

a potential loss of revenue on traffic for which they would have to lower their rates to meet increased trucking competition;

greater difficulties in handling intermodal traffic if trailers were to change size and weight.

In the next sections data for the ten years from 1978 to 1987 will be examined to determine if a shift between the two modes has occured either with respect to total conposite commodity freight or by specific commodity section. The relationship between any shift and location (origin and destination), distance range (short, medium or long), and freight type will be considered.

\subsubsection{Freight Movement Among the Central and Western Provinces 1978-87}

The total interprovincial freight carried among the six central and western provinces by the railway and trucking modes is presented in Tables 4.2 through 4.13 These tables present freight statistical data for the years 1978 through 1987 for both transport modes. Tables 4.2 and 4.3 provide specific information on freight moved from Québec to the other provinces by the railway and trucking modes respectively. By examining the tonnage moved from Québec to Ontario it can be clearly seen that there is a noteable shift of commodity tonnage movement from rail to trucking mode over 1978-87 period. Tonnage from Québec to Ontario constitutes 78 and $75 \%$ for rail, 92 and $93 \%$ for truck of the total tonnage moved from Québec to the other western and central provinces, for 1978 and 1987 respectively. 
While railway tonnage moved between these two provinces decreased from 4 million tonnes in 1978 to 2.7 million tonnes in 1987 (a $32 \%$ decline), the trucking mode increased its tonnage by $45 \%$, from 2.7 million to 4.9 million tonnes. In contrasting the freight carried by the two modes from Québec to the other provinces as shown in the tables, it is evident that each mode has kept its freight market share and no significant shift has occured.

Concrete evidence of traffic diversion from rail to truck can be observed from the total interchange movement of freight (Figure 4.2) for both transport modes between Québec and Ontario. Freight movement by trucking mode for this corridor has increased by $56 \%$ between 1978 and 1987. In comparison, the railway mode tonnage has decreased by $30 \%$ over the same corridor and period. This is a clear indication of the high level of competition between these two modes, especially when considering that for 1987 this corridor movement represents more than $27 \%$ of the total interprovincial tonnage. The market shift of freight movement from Québec to Ontario and the stable market of these modes can also be seen in Figures 4.3 through 4.6.

The same pattern of freight shift observed for movements from Québec to the other provinces, and especially to Ontario, can also be deduced from the data for movements originating in Ontario. Freight from Ontario destined to Québec constituted 53 and $46 \%$ of the rail and 78 and $77 \%$ for trucking of each mode's total tonnage from Ontario to the central and western provinces as a group, for 1978 and 1987 respectively. Table 4.4 and 4.5 show the railway and trucking tonnage generated in Ontario from 1978 through 1987 and attracted to the other provinces. Again the observation can be drawn that the railway tomnage originated at Ontario and destainated at Québec fell, by $28 \%$ from 1978, from 4.9 million tonnes to 3.5 million tonnes in 1987. Conversly, the trucking tonnage for the same links and period rose by $27 \%$, from 3.3 million tonne in 1978 to 4.5 million tonne in 1987 . In contrast to the fall and rise of freight between Ontario and Québec for both modes at this period, 
the freight movement from Ontario to the other provinces is relatively stable. Figures 4.7 through 4.10 depict the modal split for freight originated at Ontario and destined for the other provinces. 
Tonzage ('000,000)

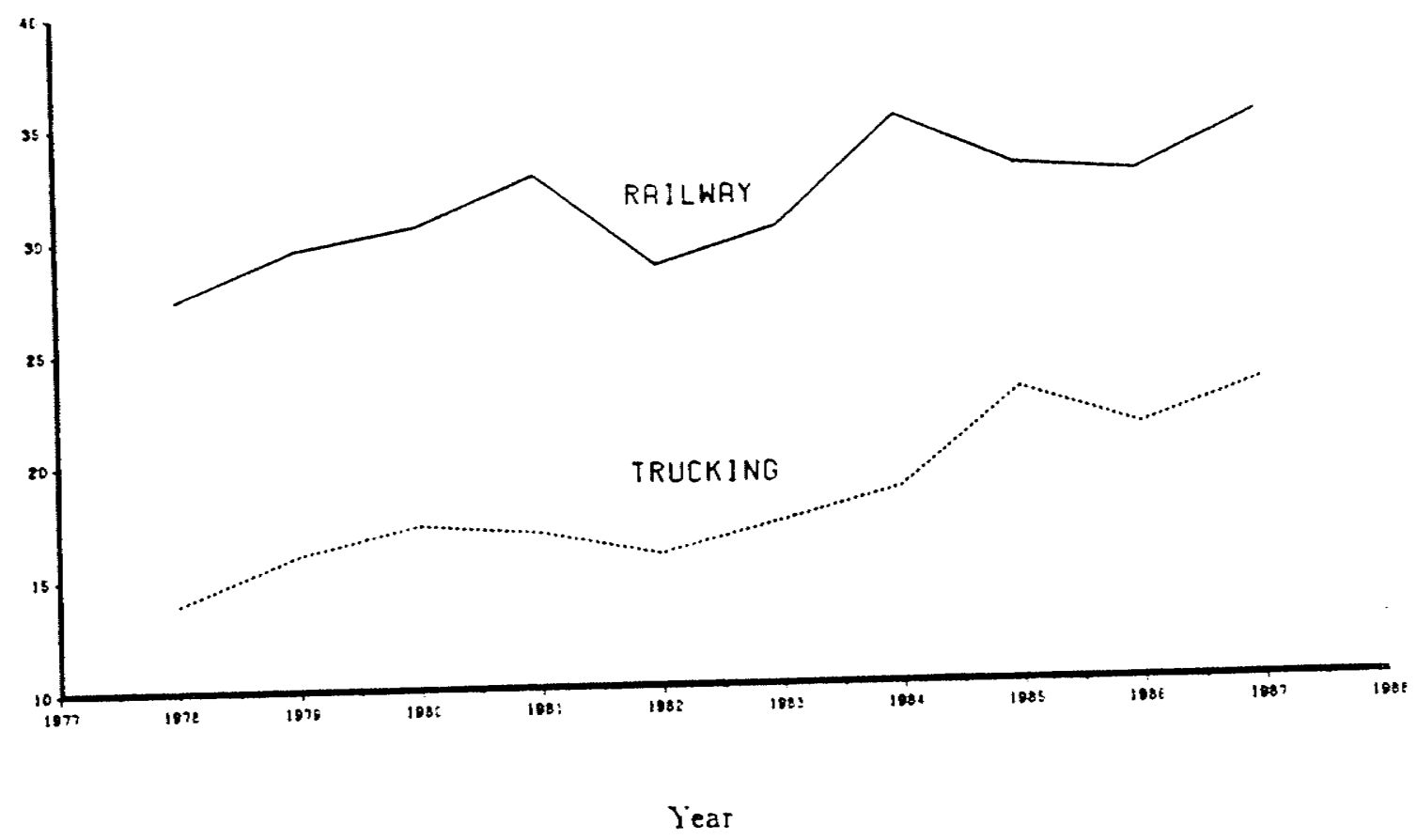

Figure 4.1 Railway vs. Trucking freight Transportation Interprovincial Tonnage

Tonnage ('000,000)

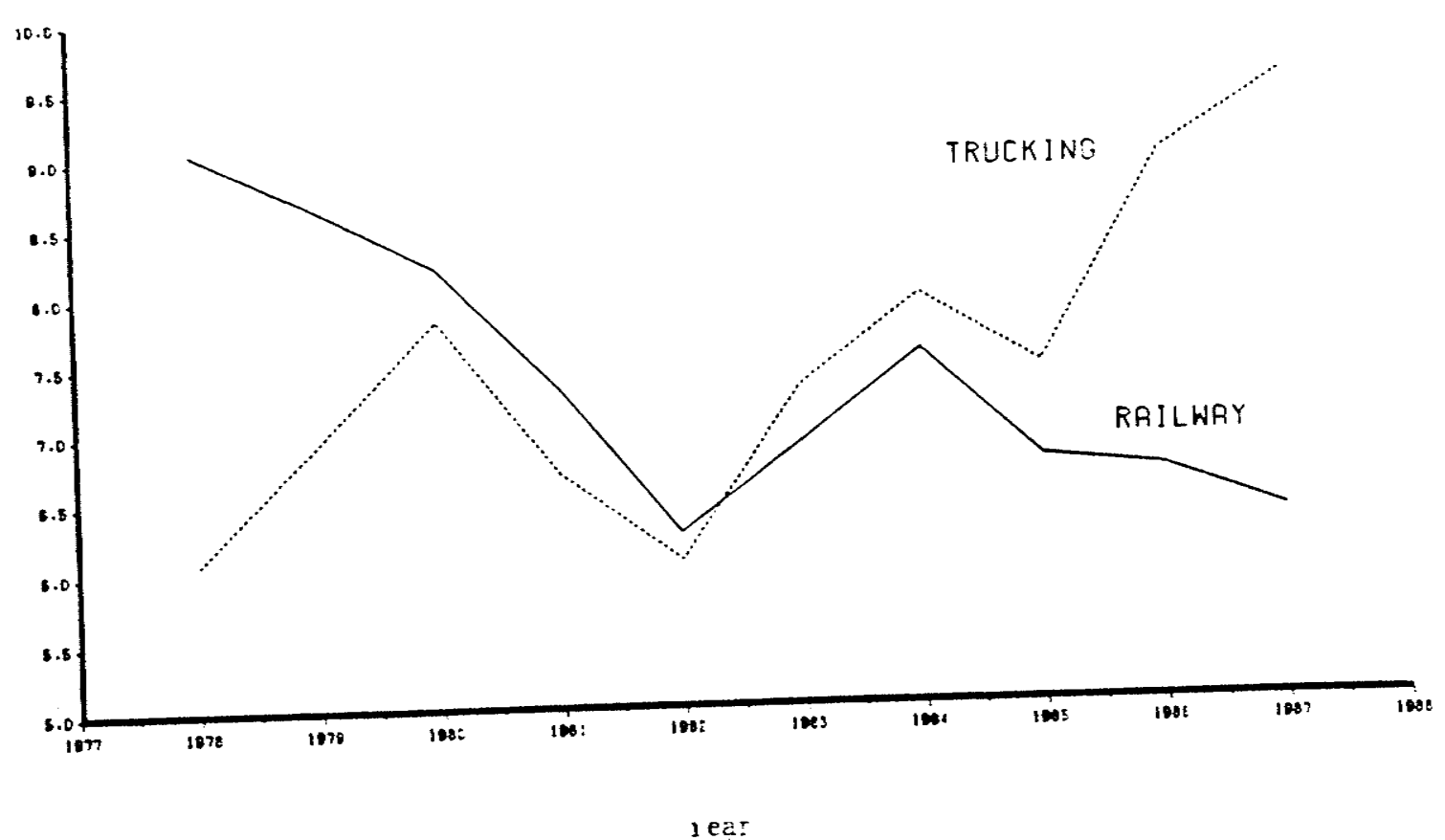

Figure 4.2 Railway vs. Trucking freight Transportation Interprovincial Tonnage between Québec and Ontario 
The tonnage moved from Manitoba, Saskatchewan, Alberta and British Columbia to the central and western provinces group for the period 1978-1987, by both railway and trucking modes is shown in Tables 4.6 through 4.13 and depicted in Figures 4.11 through 4.26. The rail tonnage from Manitoba to Saskatchewan and to Alberta by rail for example (Tables 4.6 and 4.7 and Figures 4.11 through 4.14 ) has decreased by 20 and $49 \%$ respectively. To Ontario it increased by $43 \%$ from 1978 to 1987. Contrasting the same link's movement and period for trucking (Table 4.7) show that trucking tonnage increased by $74 \%, 4 \%$ and $153 \%$ to Saskatchewan, Alberta and Ontario respectively.

The statistics for traffic originating in Saskatchewan (Tables 4.8 and 4.9 and Figures 4.15 through 4.18) show the rail tonnage destined for Manitoba decreased by $9 \%$ while to Alberta it increased by only $6 \%$ between 1978 and 1987 . During the same period the trucking increased its tonnage by $18 \%$ to Manitoba and $126 \%$ to Alberta. For longer haul freight to Québec and Ontario, for instance, railway tonnage increased by $77 \%$ and $400 \%$ respectively from 1978 to 1987 ; while trucking tonnage to Québec registered no increase and to Ontario increased by only $54 \%$.

Rail tonnage originating in Alberta over the 1978 to 1987 period shows a 45\% decrease in freight to Saskatchewan, and $40 \%$ and $378 \%$ increases of railway traffic volume to Manitoba and Ontario. For trucking for same links and period, increases of $124 \%, 197 \%$ and $248 \%$ are registered for the same three destinations respectively. This can be clearly seen from Tables 4.10 and 4.11 and Figures 4.19 through 4.22 . It is also can be seen that while railway tonnage to Québec increased by $57 \%$, trucking tonnage showed no significant increase over the period.

The tonnage generated in British Columbia during the 1978-87 period and moved to prairie provinces (Alberta, Saskatchewan and Manitoba) increaed by $21 \%$, $68 \%$ and $25 \%$ for rail and increased by $75 \%, 100 \%$ and $121 \%$ for trucking for respective destinations. Conversly, the traffic volumes moved longer distances, namely to Ontario and Québec, increased by $225 \%$ and $178 \%$ for rail and increased only by $48 \%$ 


$$
-45-
$$

and $22 \%$ for truck.

In general, both railway and trucking industries have increased their traffic volumes over the years, The railway share decreased over this period between adjacent provinces in favour of increasing traffic volumes by truck. In the longer haul market, the opposite observation can be drawn, where the rail is carrying a substantial and increased share over the years while trucking traffic is stable. 
Table 4.2 Railway Tonnage $\left(\times 10^{3} t\right)$ Moved Form Québec to the Other Western and Central Provinces 1978 - 1987

\begin{tabular}{ccccccc}
\hline Year & Ont. & Man. & Sask. & Alta. & B.C. & Total \\
\hline 1978 & 4079 & 269 & 89 & 542 & 282 & 5237 \\
1979 & 3430 & 290 & 113 & 718 & 329 & 4880 \\
1980 & 2913 & 312 & 107 & 558 & 397 & 4287 \\
1981 & 2969 & 265 & 97 & 451 & 367 & 4149 \\
1982 & 2385 & 226 & 81 & 335 & 282 & 3309 \\
1983 & 2739 & 240 & 88 & 339 & 281 & 3687 \\
1984 & 2838 & 241 & 100 & 372 & 293 & 3844 \\
1985 & 2851 & 247 & 79 & 350 & 294 & 3821 \\
1986 & 2905 & 229 & 70 & 335 & 300 & 3839 \\
1987 & 2784 & 236 & 81 & 331 & 298 & 3730 \\
\hline
\end{tabular}

Table 4.3 Trucking Tonnage $\left(\times 10^{3} t\right)$ Moved From Québec to the Other Western and Central Provinces 1978 - 1987

\begin{tabular}{ccccccc}
\hline Year & Ont. & Man. & Sask. & Alta. & B.C. & Total \\
\hline 1978 & 2722 & 74 & 18 & 83 & 73 & 2970 \\
1979 & 3217 & 115 & 16 & 155 & 81 & 3584 \\
1980 & 4141 & 109 & 49 & 130 & 72 & 4501 \\
1981 & 3363 & 71 & 27 & 113 & 104 & 3678 \\
1982 & 2944 & 87 & 36 & 106 & 87 & 3260 \\
1983 & 3695 & 110 & 22 & 101 & 64 & 3992 \\
1984 & 3794 & 93 & 28 & 107 & 109 & 4131 \\
1985 & 3775 & 115 & 14 & 99 & 109 & 4112 \\
1986 & 4626 & 101 & 30 & 110 & 81 & 4948 \\
1987 & 4912 & 117 & 38 & 133 & 92 & 5292 \\
\hline
\end{tabular}


Tonnage ( $(000)$

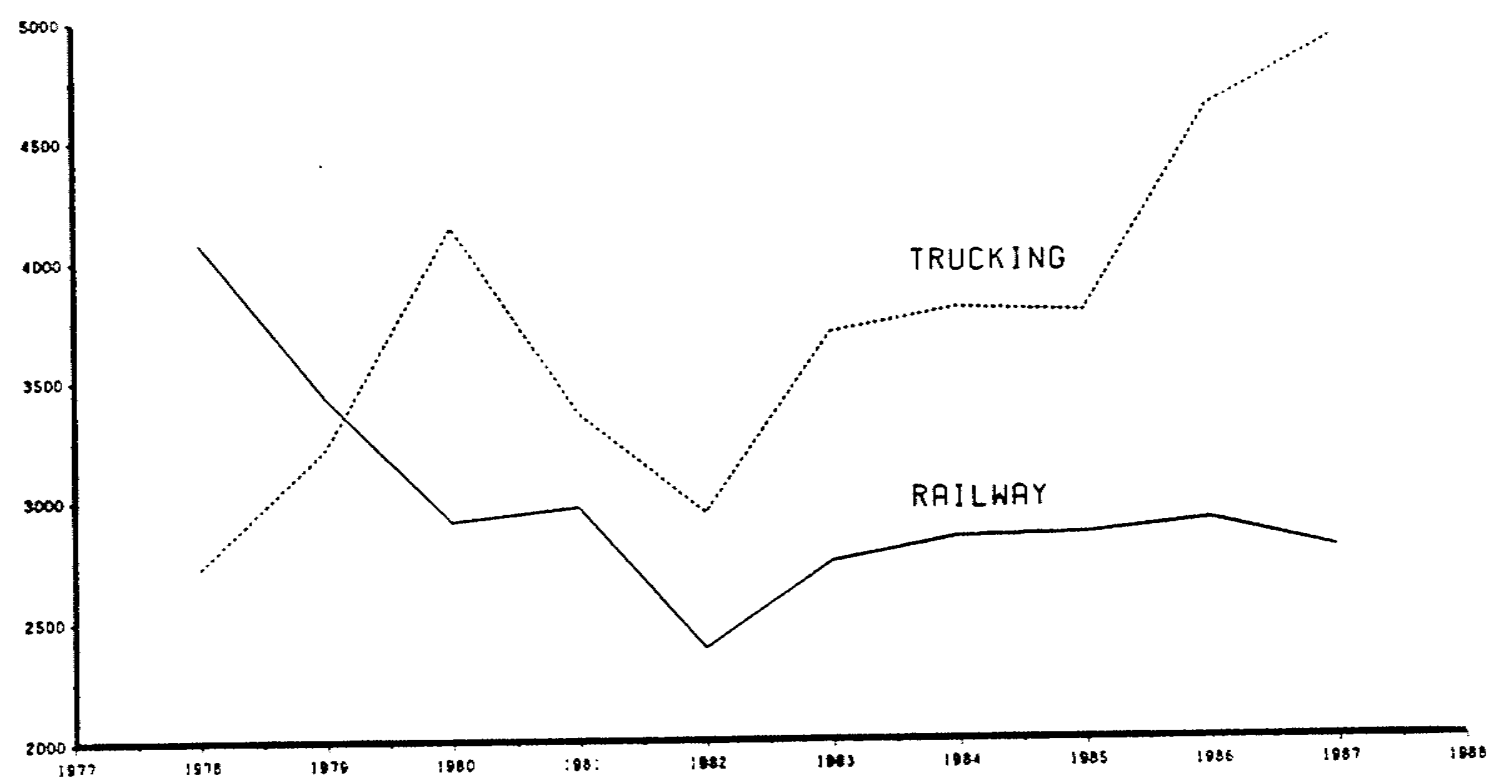

lea:

Figure 4.3 Railway $v s$. Trucking freight Transportation

Interprovincial Tonnage From Québec to Ontario

Tonnage ('000)

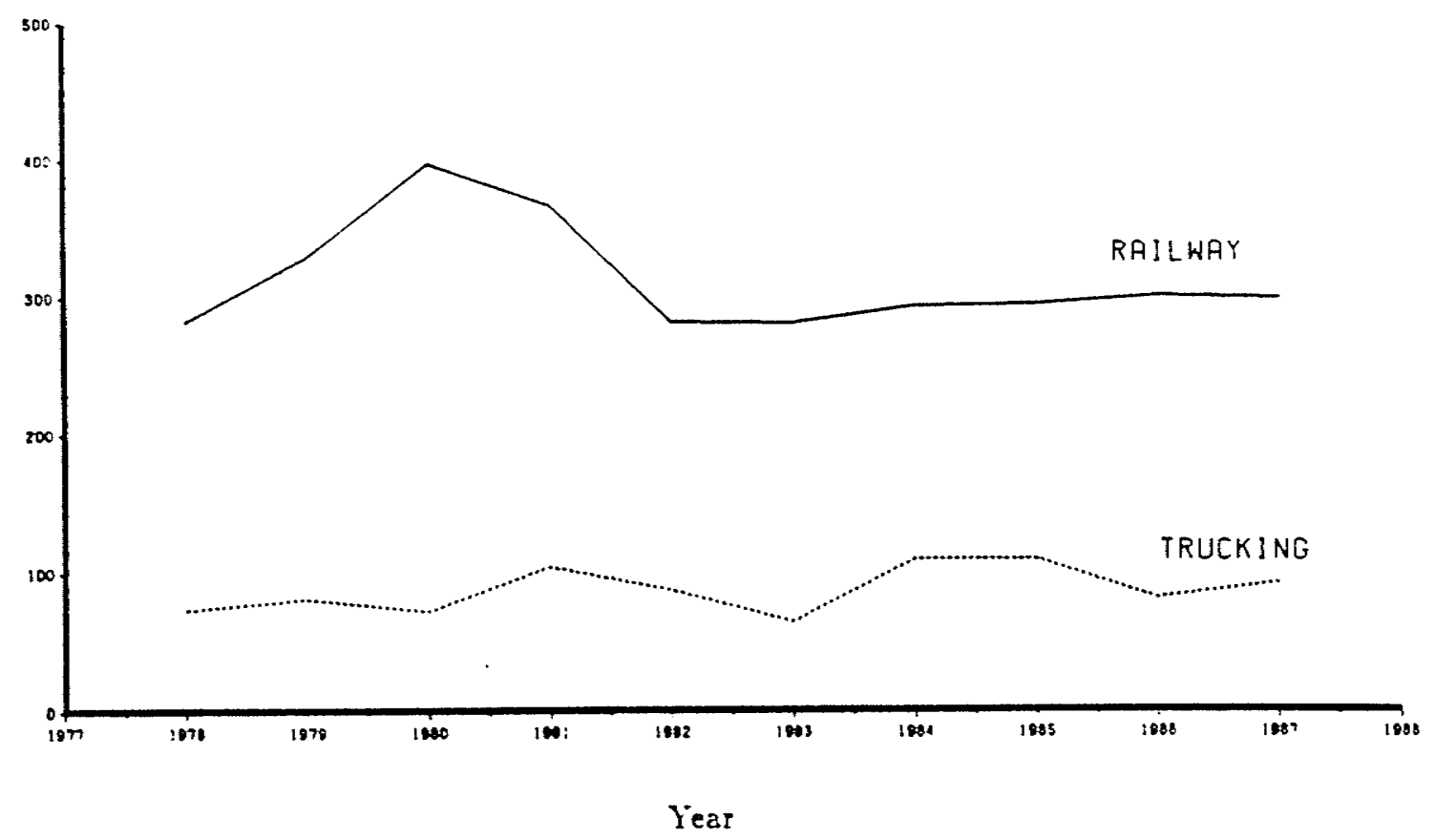

Figure 4.4 Railway $v s$. Trucking freight Transportation Interprovincial Tonnage From Québec to British Columbia 
Tonnage ('000)

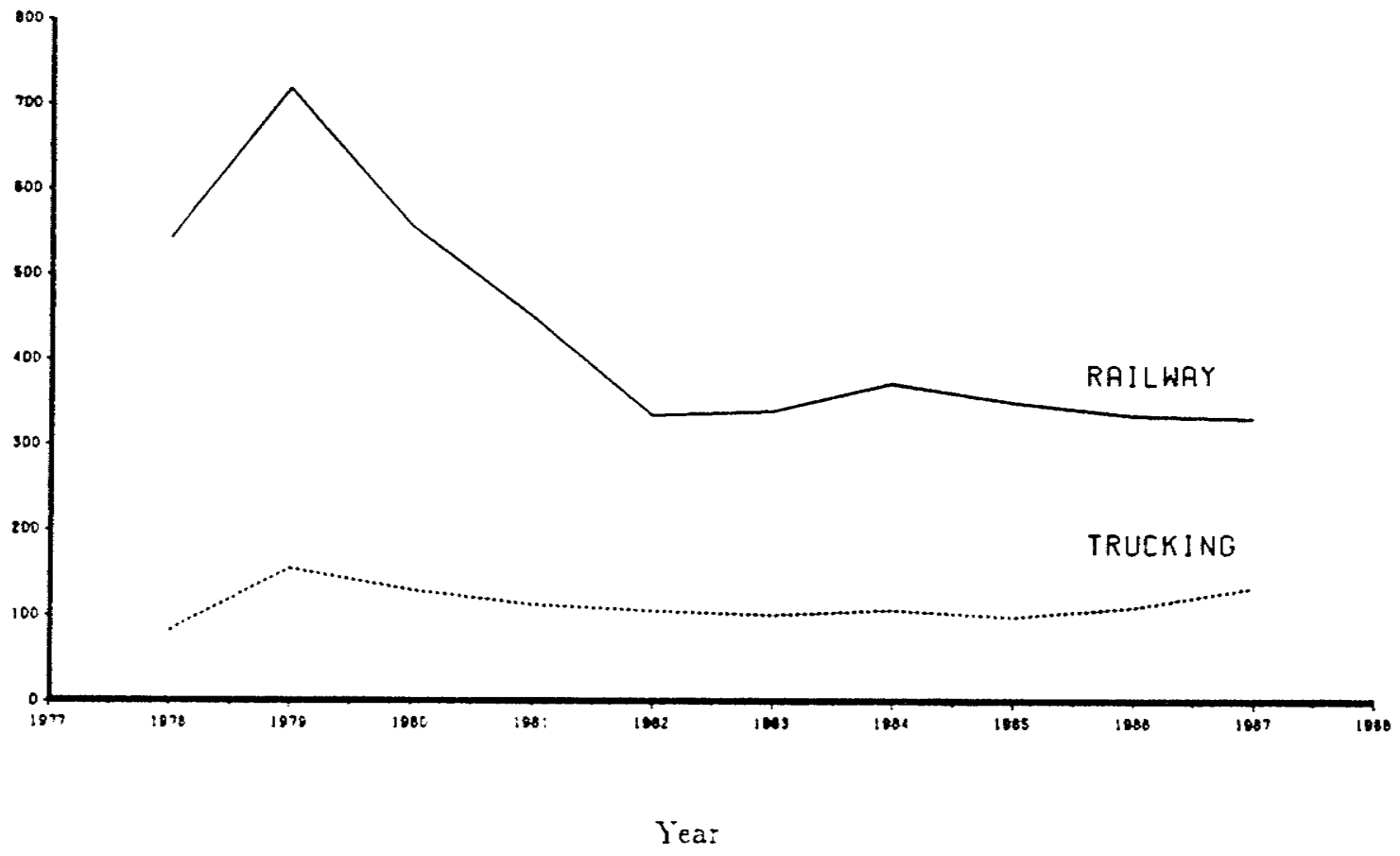

Figure 4.5 Railway vs . Trucking freight Transportation

Inte-provincial Tonnage From Québec to Alberta

Tonnage ('000!

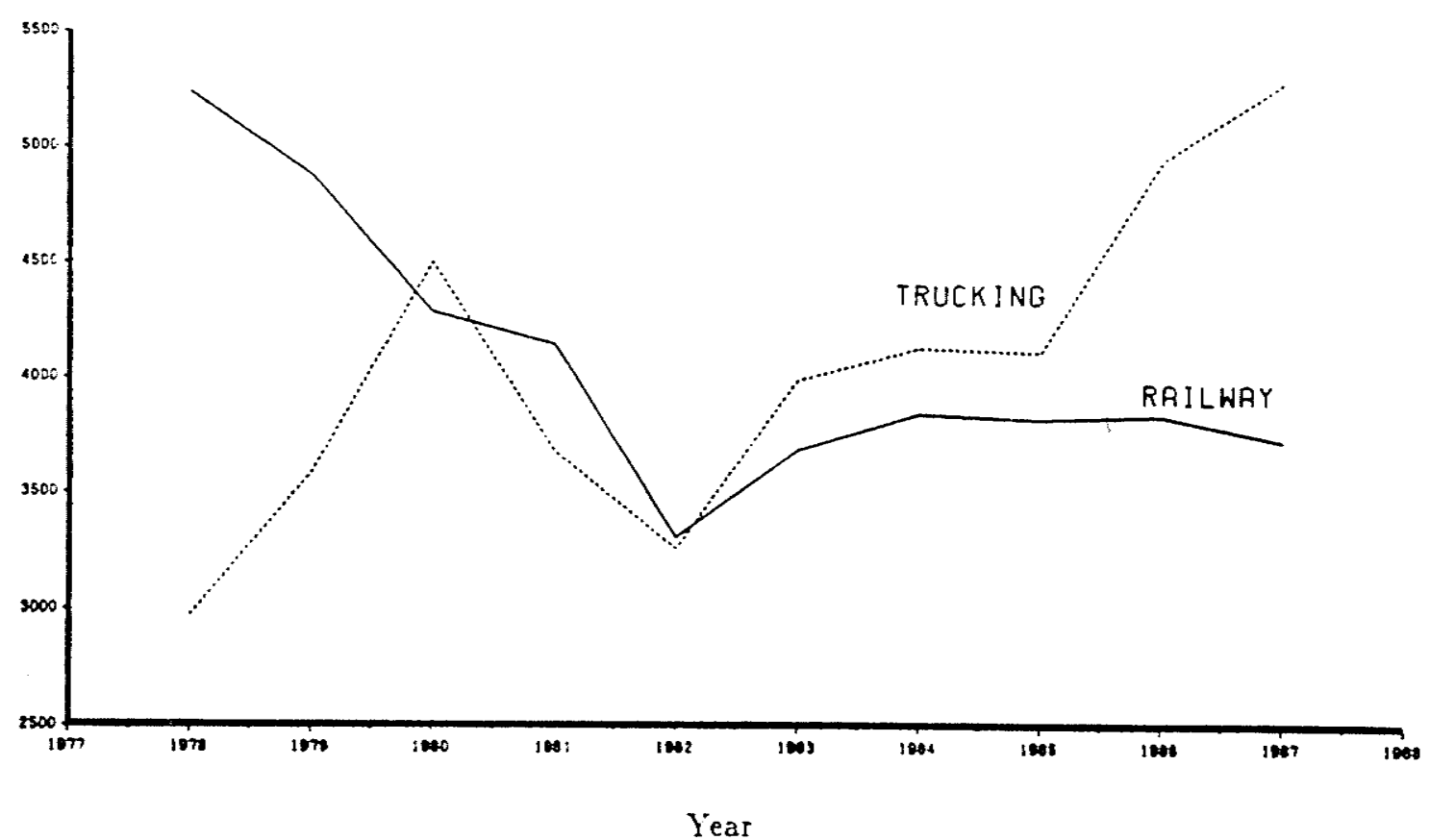

Figure 4.6 Railway vs. Trucking freight Transportation Interprovincial Tonnage From Québec to the Central and Western Provinces 
Table 4.4 Railway Tonnage $\left(\times 10^{3} t\right)$ Moved From Ontario to the Other Western and Central Provinces 1978 - 1987

\begin{tabular}{ccccccc}
\hline Year & Qué. & Man. & Sask. & Alta. & B.C. & Total \\
\hline 1978 & 4975 & 1130 & 405 & 1698 & 1119 & 9327 \\
1979 & 5218 & 1277 & 463 & 2244 & 1313 & 10515 \\
1980 & 5284 & 1222 & 516 & 2386 & 1502 & 10910 \\
1981 & 4348 & 1262 & 565 & 2585 & 1431 & 10191 \\
1982 & 3863 & 948 & 368 & 1601 & 979 & 7759 \\
1983 & 4155 & 968 & 432 & 1550 & 1108 & 8213 \\
1984 & 4709 & 1018 & 437 & 1723 & 1077 & 8964 \\
1985 & 3911 & 992 & 403 & 1919 & 1146 & 8371 \\
1986 & 3765 & 1116 & 388 & 1608 & 1140 & 8017 \\
1987 & 3569 & 1042 & 434 & 1594 & 1187 & 7826 \\
\hline
\end{tabular}

Table 4.5 Trucking Tonnage $\left(\times 10^{3} t\right)$ Moved From Ontario to the Other Western and Central Provinces 1978 - 1987

\begin{tabular}{ccccccc}
\hline Year & Qué. & Man. & Sask. & Alta. & B.C. & Total \\
\hline 1978 & 3349 & 401 & 65 & 300 & 177 & 4292 \\
1979 & 3709 & 456 & 120 & 314 & 262 & 4861 \\
1980 & 3671 & 343 & 107 & 319 & 211 & 4651 \\
1981 & 3322 & 379 & 125 & 387 & 216 & 4429 \\
1982 & 3109 & 428 & 80 & 384 & 233 & 4234 \\
1983 & 3608 & 320 & 85 & 375 & 228 & 4616 \\
1984 & 4155 & 370 & 127 & 380 & 267 & 5299 \\
1985 & 3658 & 427 & 113 & 396 & 253 & 8417 \\
1986 & 4323 & 393 & 134 & 410 & 343 & 5603 \\
1987 & 4584 & 442 & 136 & 503 & 280 & 5945 \\
\hline
\end{tabular}


Tonnage ('000)

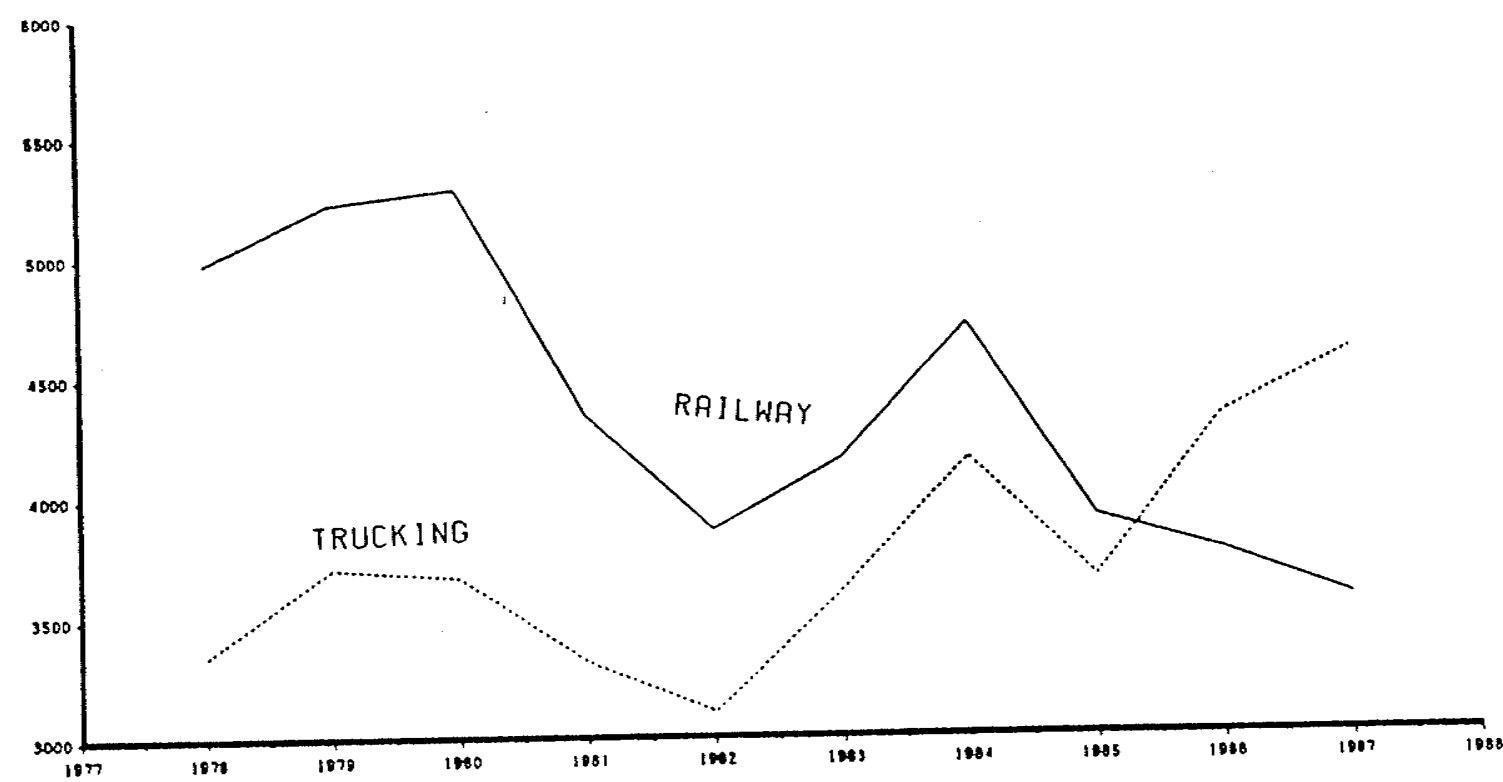

Year

Figure 4.7 Railway $v s$. Trucking freight Transportation Interprovincial Tonnage From Ontario to Québec

Tonnage ('000)

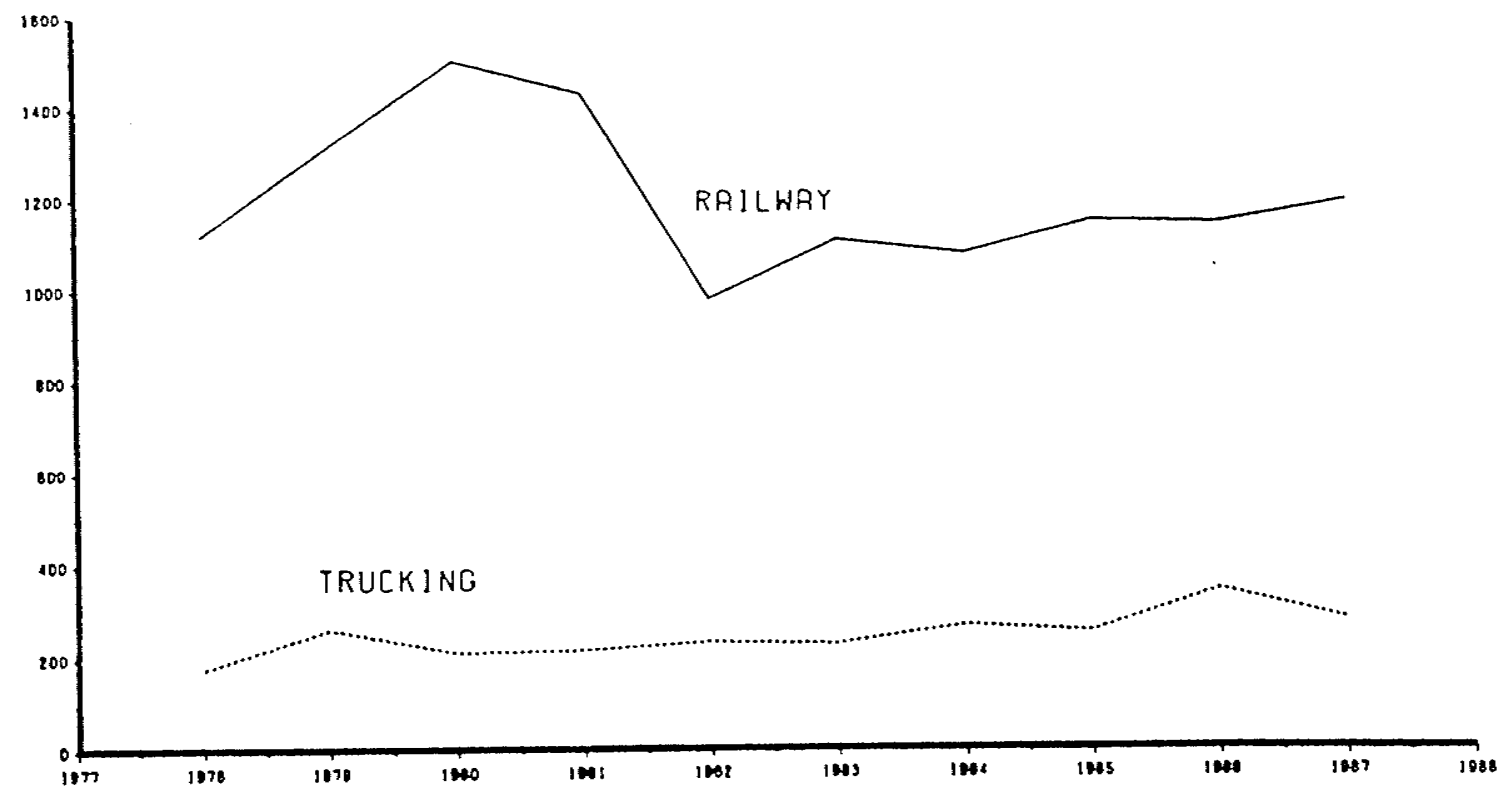

Year

Figure 4.8 Railway vs . Trucking freight Transportation Interprovincial Tonnage From Ontario to British Columbia 
Tonnage ('000)

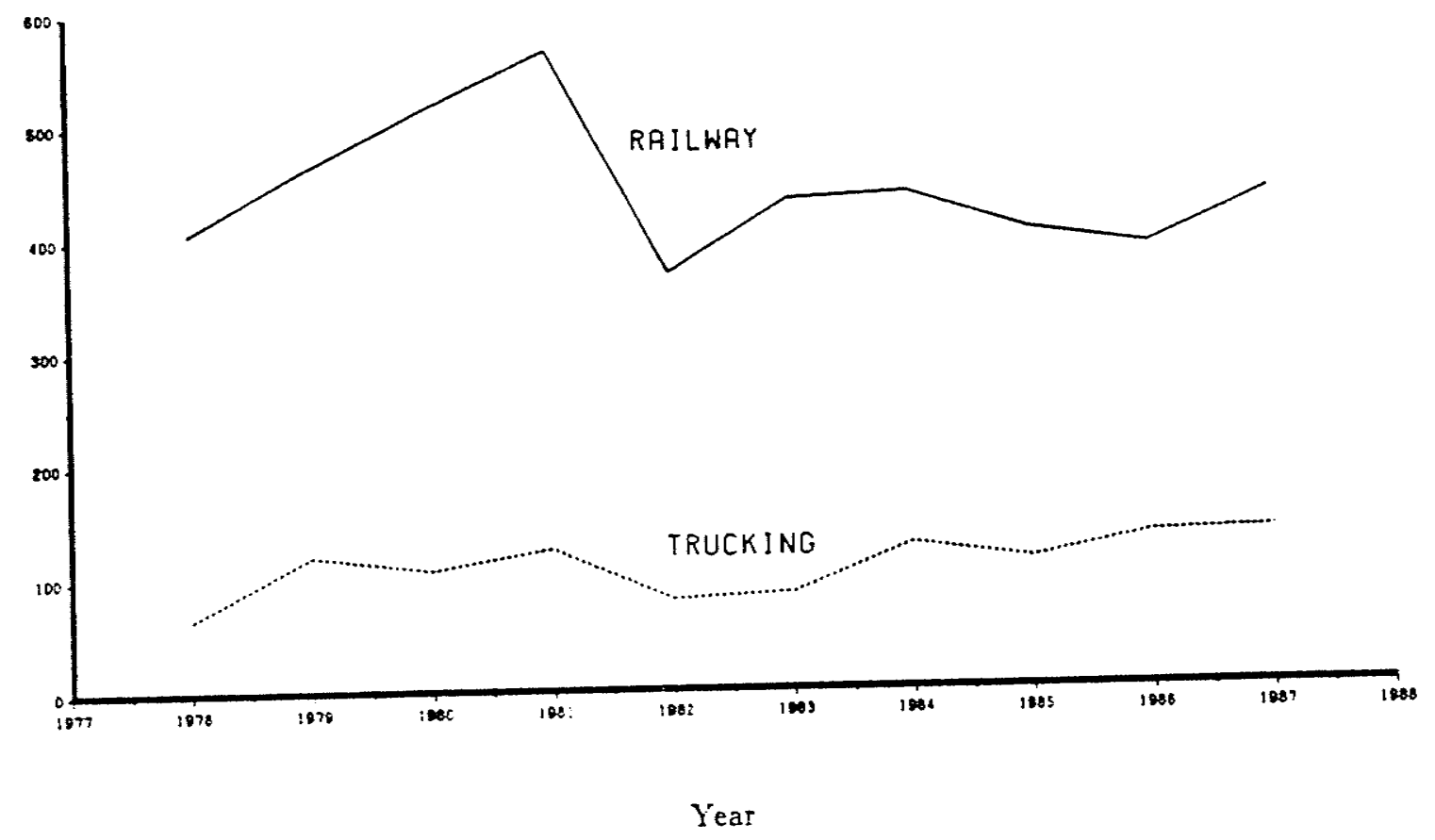

Figure 4.9 Railway $v s$. Trucking freight Transportation Inter provincial Tonnage 'ron Ontario to Saskatchewan Tonrage ('000)

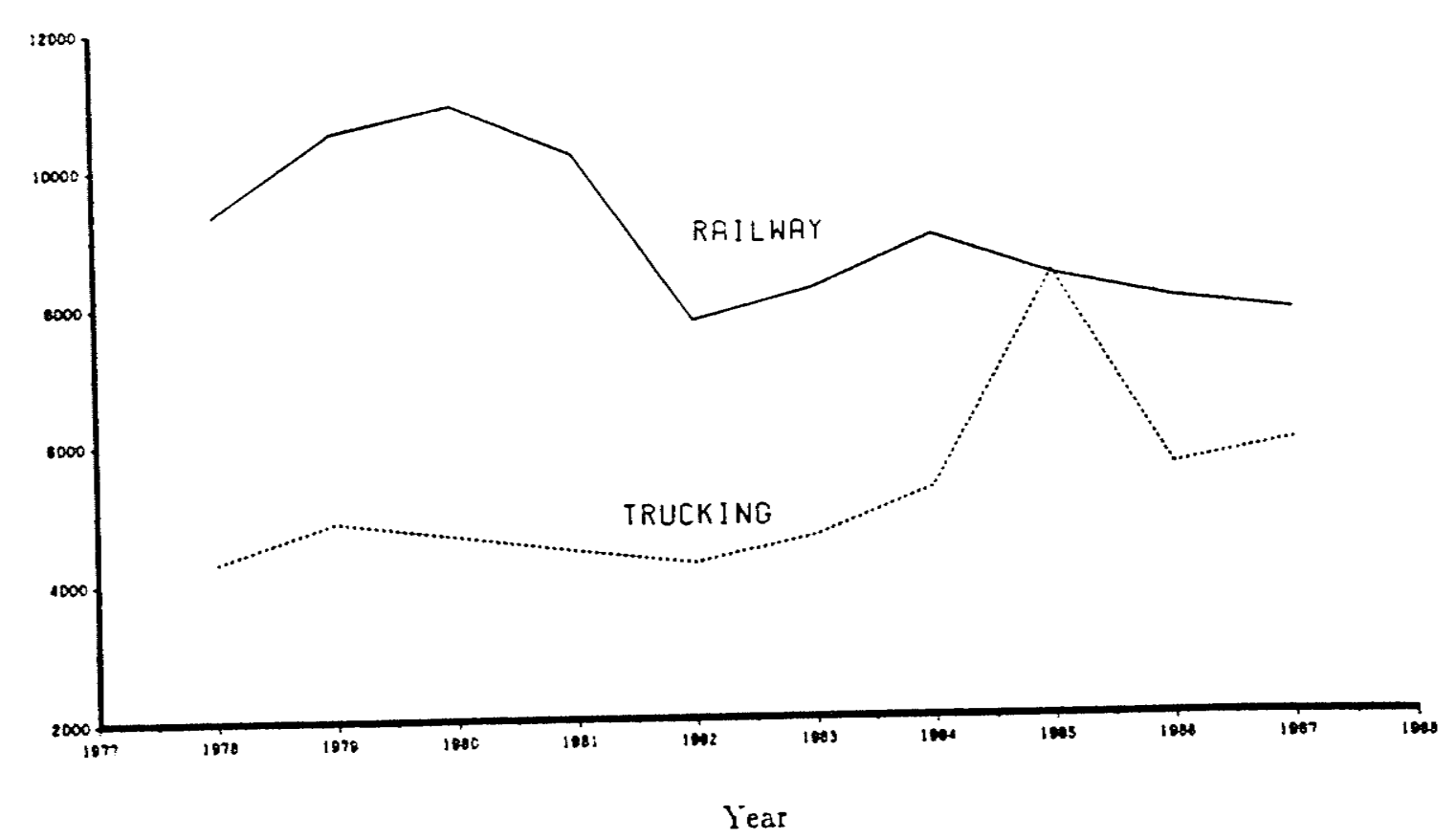

Figure 4.10 Railway vs. Trucking freight Transportation Interprovincial Tonnage From Ontario to the Other Central and Western Provinces 
Table 4.6 Railway Tonnage $\left(\times 10^{3} t\right)$ Moved From Manitoba to the Other Western and Central Provinces 1978 - 1987

\begin{tabular}{ccccccc}
\hline Year & Qué. & Ont. & Sask. & Alta. & B.C. & Total \\
\hline 1978 & 382 & 842 & 714 & 386 & 113 & 1673 \\
1979 & 392 & 1108 & 754 & 455 & 177 & 2886 \\
1980 & 453 & 1028 & 700 & 627 & 238 & 3046 \\
1981 & 371 & 969 & 722 & 649 & 268 & 2979 \\
1982 & 425 & 772 & 421 & 329 & 190 & 2137 \\
1983 & 454 & 860 & 486 & 255 & 180 & 2235 \\
1984 & 425 & 964 & 423 & 280 & 290 & 2311 \\
1985 & 420 & 879 & 385 & 246 & 250 & 2180 \\
1986 & 444 & 980 & 406 & 231 & 198 & 2259 \\
1987 & 414 & 1203 & 572 & 198 & 197 & 2584 \\
\hline
\end{tabular}

Table 4.7 Trucking Tonnage $\left(\times 10^{3} t\right)$ Moved From Manitoba to the Other Western and Central Provinces 1978 - 1987

\begin{tabular}{ccccccc}
\hline Year & Qué & Ont. & Sask. & Alta. & B.C. & Total \\
\hline 1978 & 68 & 391 & 376 & 253 & 127 & 1215 \\
1979 & 118 & 445 & 390 & 197 & 75 & 1225 \\
1980 & 143 & 435 & 361 & 317 & 101 & 1357 \\
1981 & 83 & 466 & 450 & 293 & 113 & 1405 \\
1982 & 99 & 405 & 470 & 261 & 74 & 1309 \\
1983 & 58 & 444 & 439 & 309 & 91 & 1341 \\
1984 & 64 & 486 & 597 & 386 & 80 & 1613 \\
1985 & 91 & 565 & 440 & 328 & 123 & 1547 \\
1986 & 117 & 543 & 502 & 358 & 117 & 1637 \\
1987 & 120 & 990 & 654 & 344 & 117 & 2225 \\
\hline
\end{tabular}


Tonnage ('000)

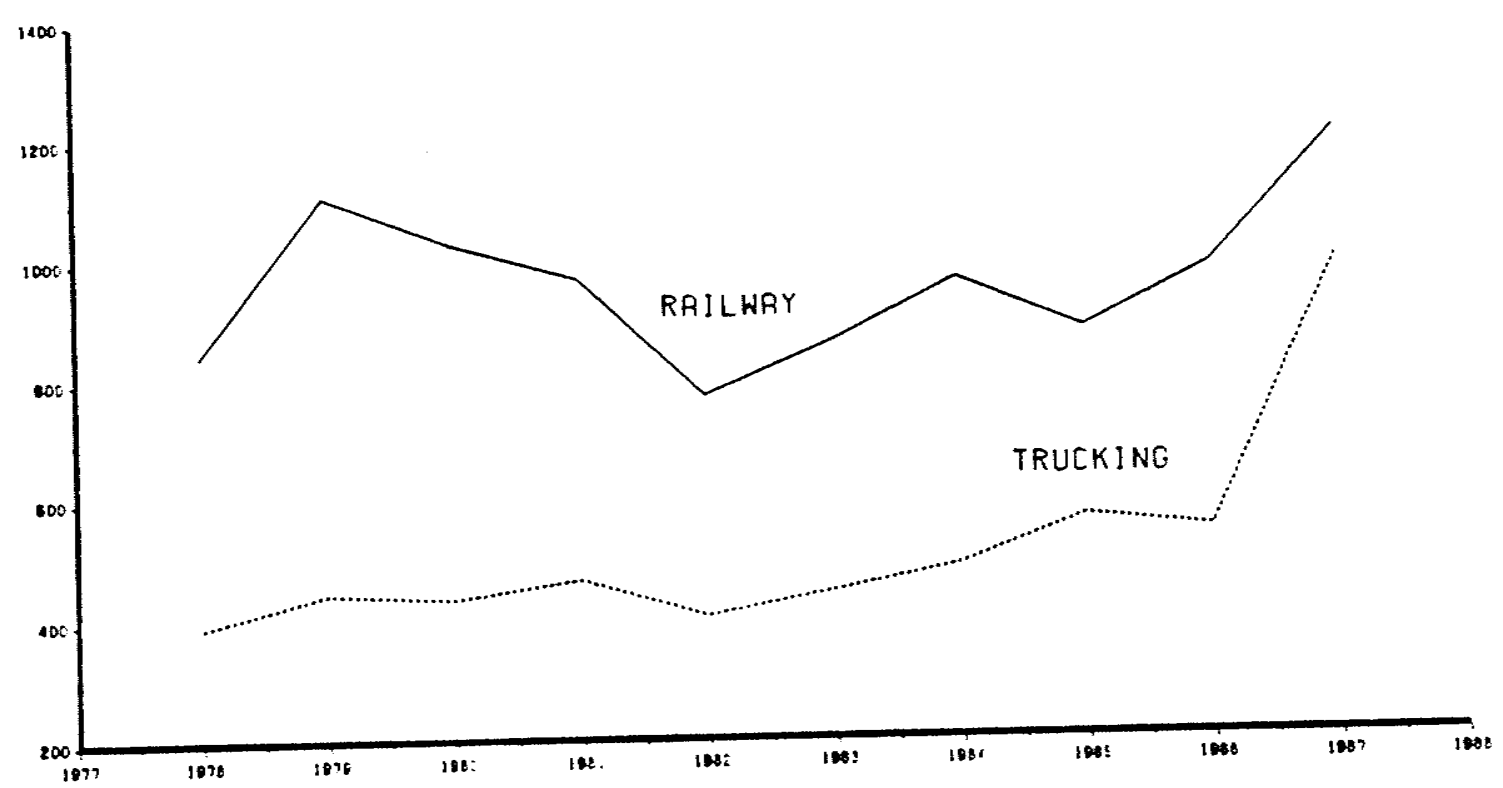

lea:

Figure 4.11 Railway $v s$. Trucking freight Transportation Interprovincial Tonnage From Manitoba to Ontario

Tonnage ('000)

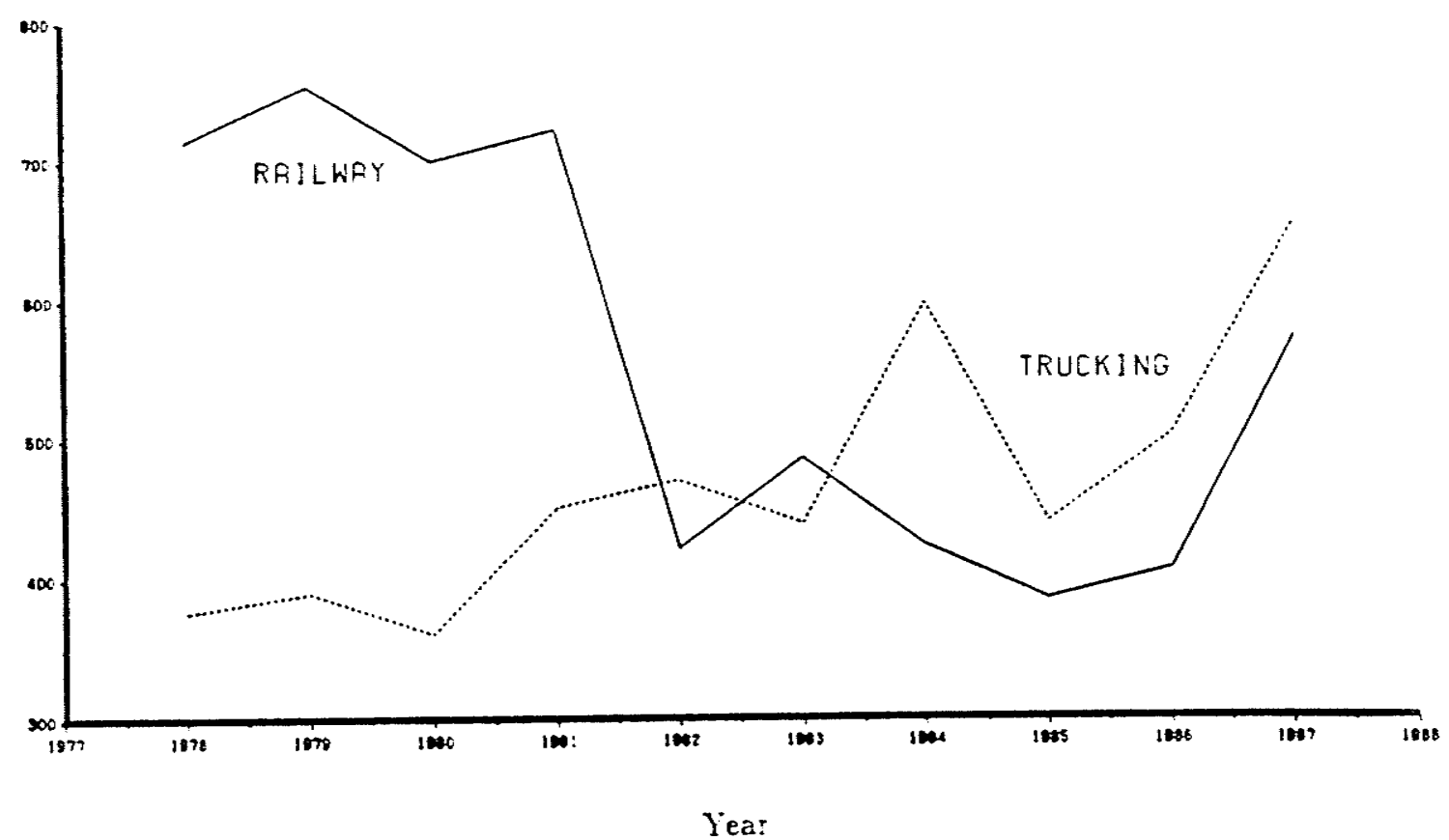

Figure 4.12 Railway $v s$. Trucking freight Transportation Interprovincial Tonnage From Manitoba to Saskatchewan 
Tonnage ('000)

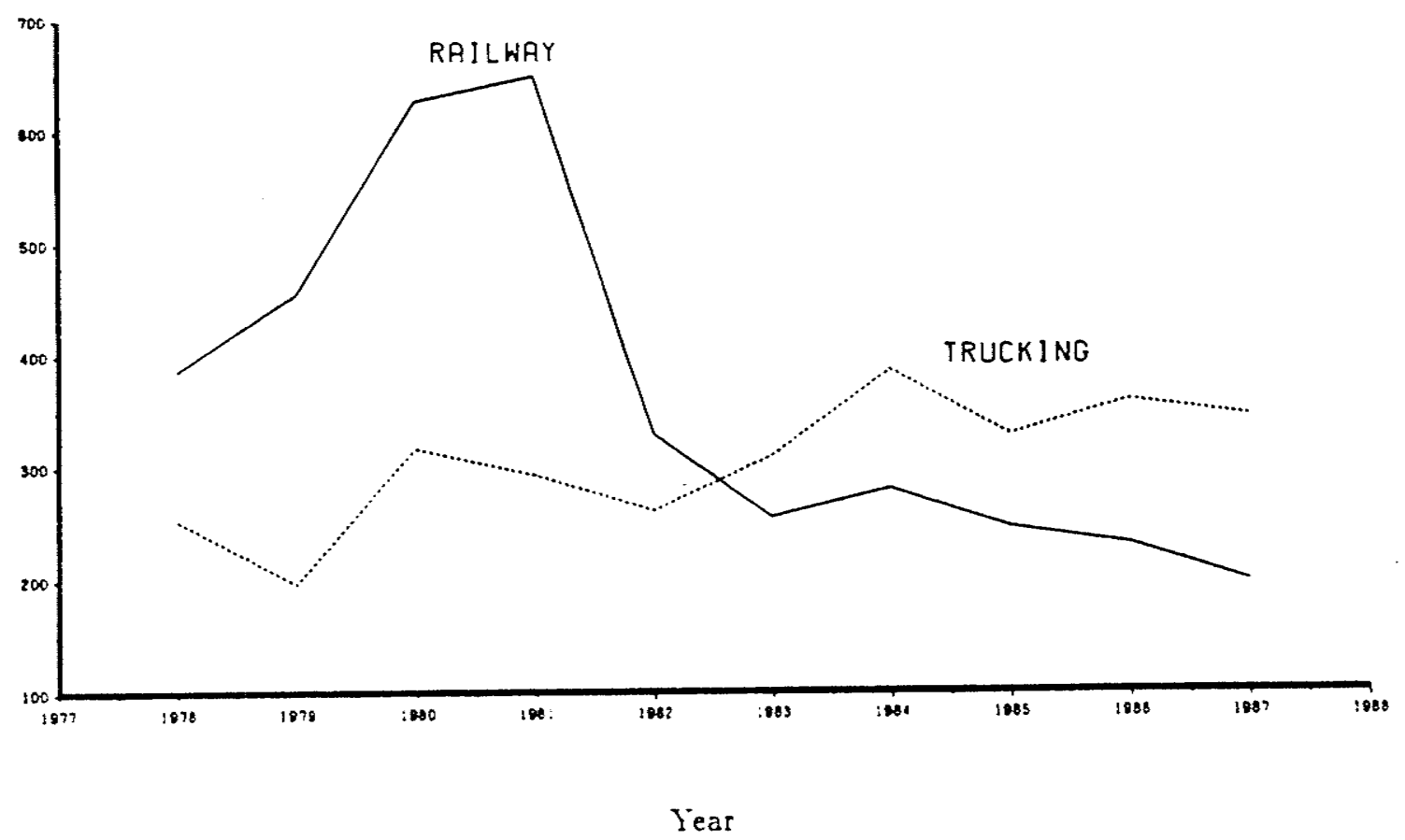

Figure 4.13 Railway $v s$. Trucking freight Transportation Interprovincial Tonnage From Manitoba to Albertc.

Tonnage (:000)

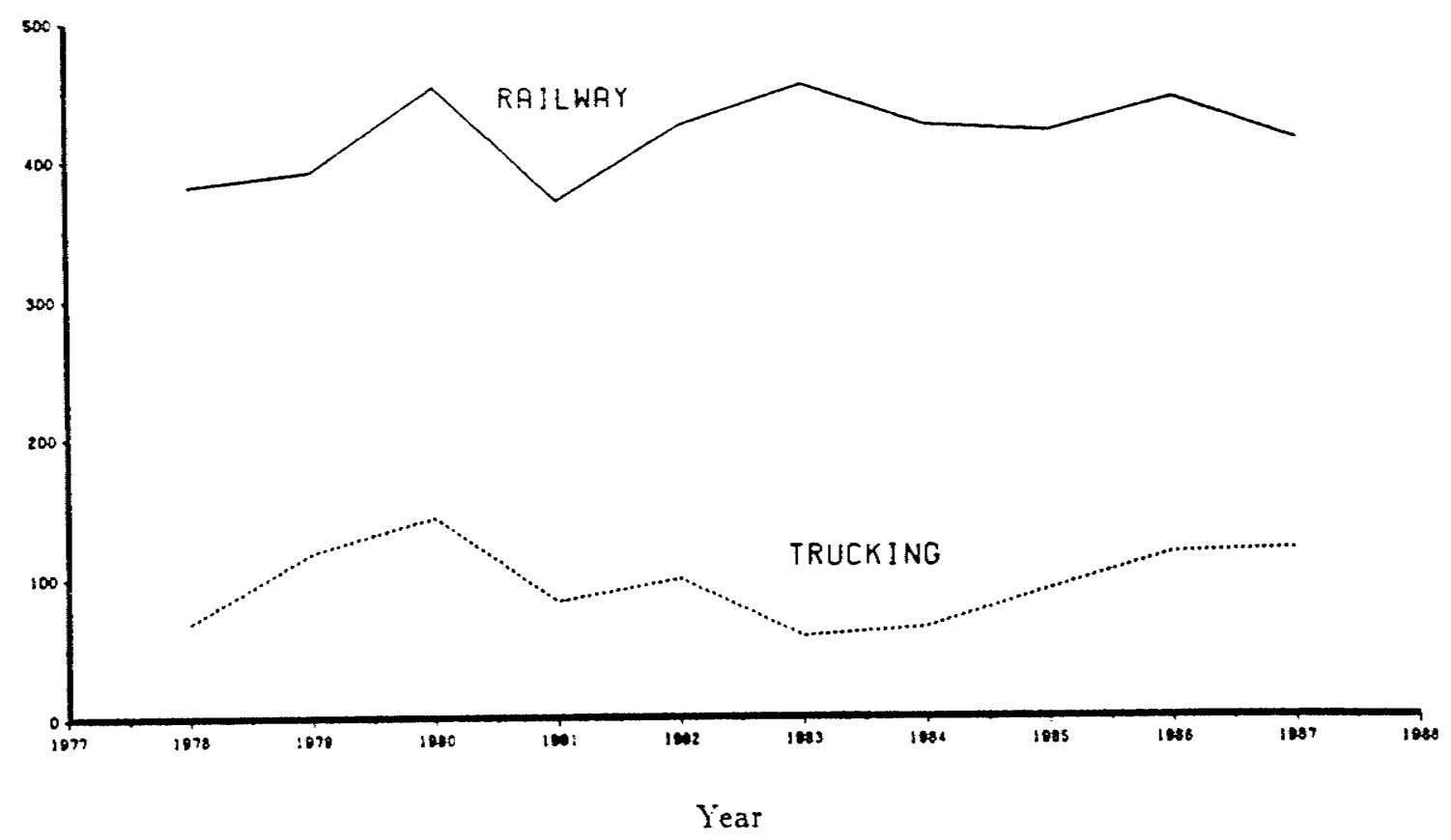

Figure 4.14 Railway vs. Trucking freight Transportation Interprovincial Tonnage From Manitoba to Québec 
Table 4.8 Railway Tonnage $\left(\times 10^{3} t\right)$ Moved From Saskatchewan to the Other Western and Central Provinces 1978 - 1987

\begin{tabular}{ccccccc}
\hline Year & Qué. & Ont. & Man. & Alta. & B.C. & Total \\
\hline 1978 & 296 & 748 & 1041 & 235 & 287 & 2607 \\
1979 & 360 & 883 & 731 & 241 & 301 & 2516 \\
1980 & 281 & 1122 & 846 & 294 & 282 & 2825 \\
1981 & 333 & 2327 & 902 & 260 & 479 & 4301 \\
1982 & 324 & 2774 & 570 & 227 & 672 & 4567 \\
1983 & 437 & 2659 & 487 & 236 & 736 & 4555 \\
1984 & 535 & 3608 & 641 & 309 & 1044 & 6137 \\
1985 & 359 & 3082 & 655 & 276 & 537 & 4909 \\
1986 & 464 & 2949 & 546 & 259 & 444 & 4662 \\
1987 & 525 & 3702 & 948 & 249 & 465 & 5889 \\
\hline
\end{tabular}

Table 4.9 Trucking Tonnage $\left(\times 10^{3} t\right)$ Moved From Saskatchewan to the Other Western and Central Provinces 1978 - 1987

\begin{tabular}{ccccccc}
\hline Year & Qué. & Ont. & Man. & Alta. & B.C. & Total \\
\hline 1978 & 17 & 71 & 550 & 471 & 97 & 1206 \\
1979 & 15 & 68 & 293 & 526 & 85 & 987 \\
1980 & 9 & 41 & 303 & 528 & 103 & 984 \\
1981 & 12 & 49 & 429 & 1007 & 69 & 1566 \\
1982 & 38 & 50 & 424 & 1060 & 94 & 1666 \\
1983 & 15 & 87 & 464 & 697 & 86 & 1349 \\
1984 & 31 & 67 & 528 & 698 & 88 & 1412 \\
1985 & 23 & 81 & 605 & 1343 & 135 & 2187 \\
1986 & 24 & 116 & 929 & 1124 & 151 & 2344 \\
1987 & 18 & 109 & 649 & 1065 & 123 & 1964 \\
\hline
\end{tabular}


Ton:age ('0001)

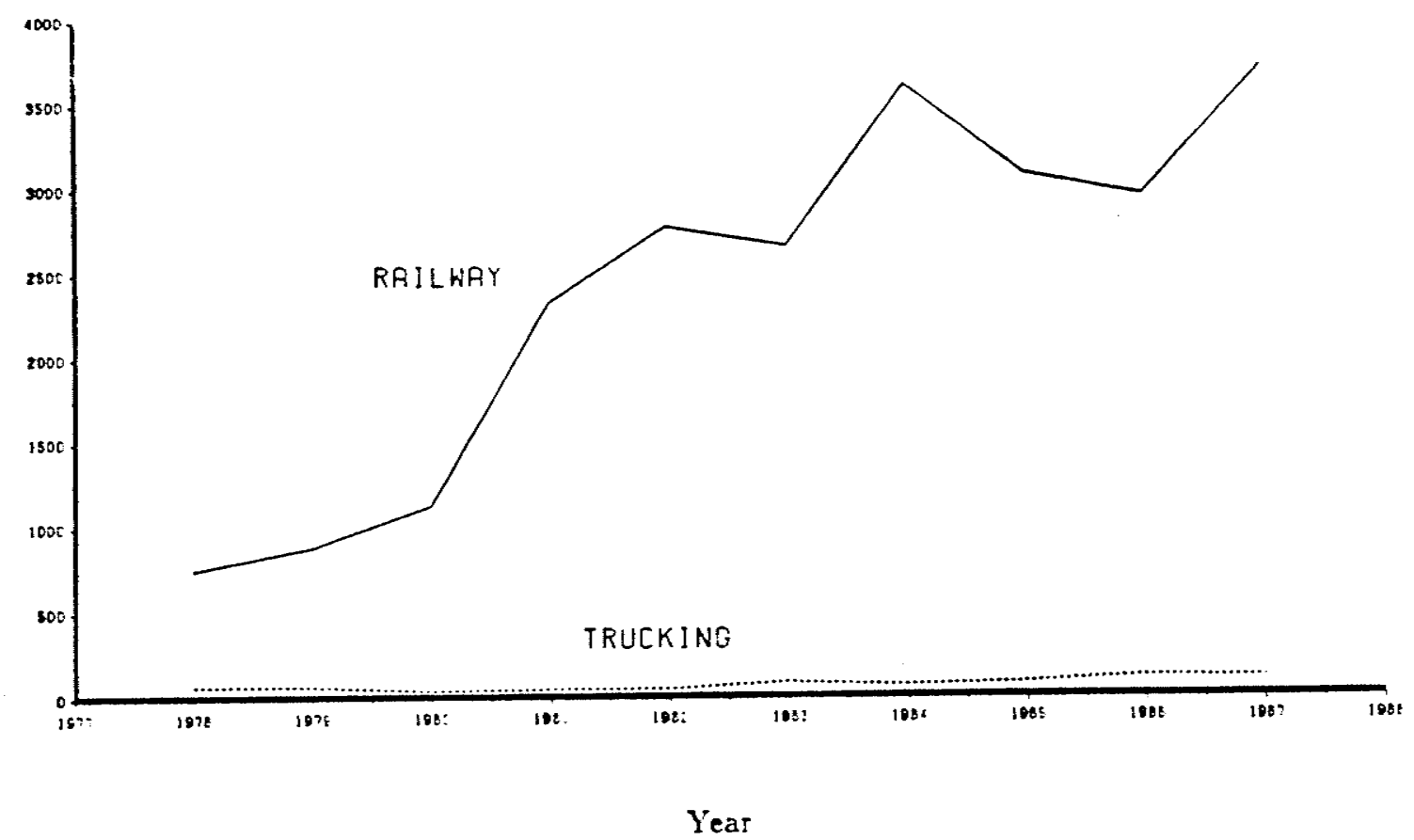

Figure 4.15 Railway vs. Trucking freight Transportation Interprovincial Tonnage From Saskatchewan to Ontario

Tonnage ('000)

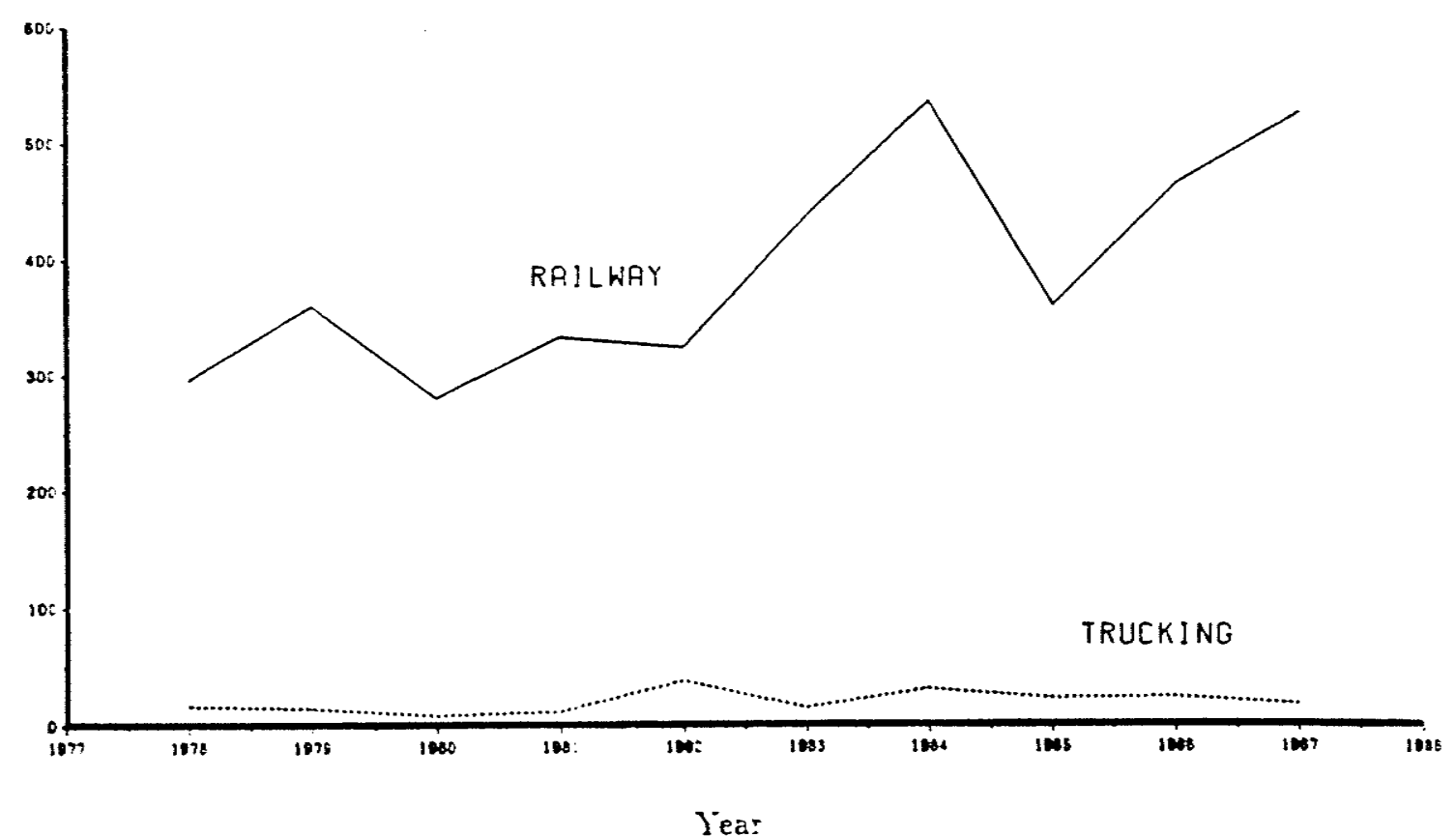

Figure 4.16 Railway vs. Trucking freight Transportation Interprovincial Tonnage From Saskatchewan to Québec 
Tonnage ('000)

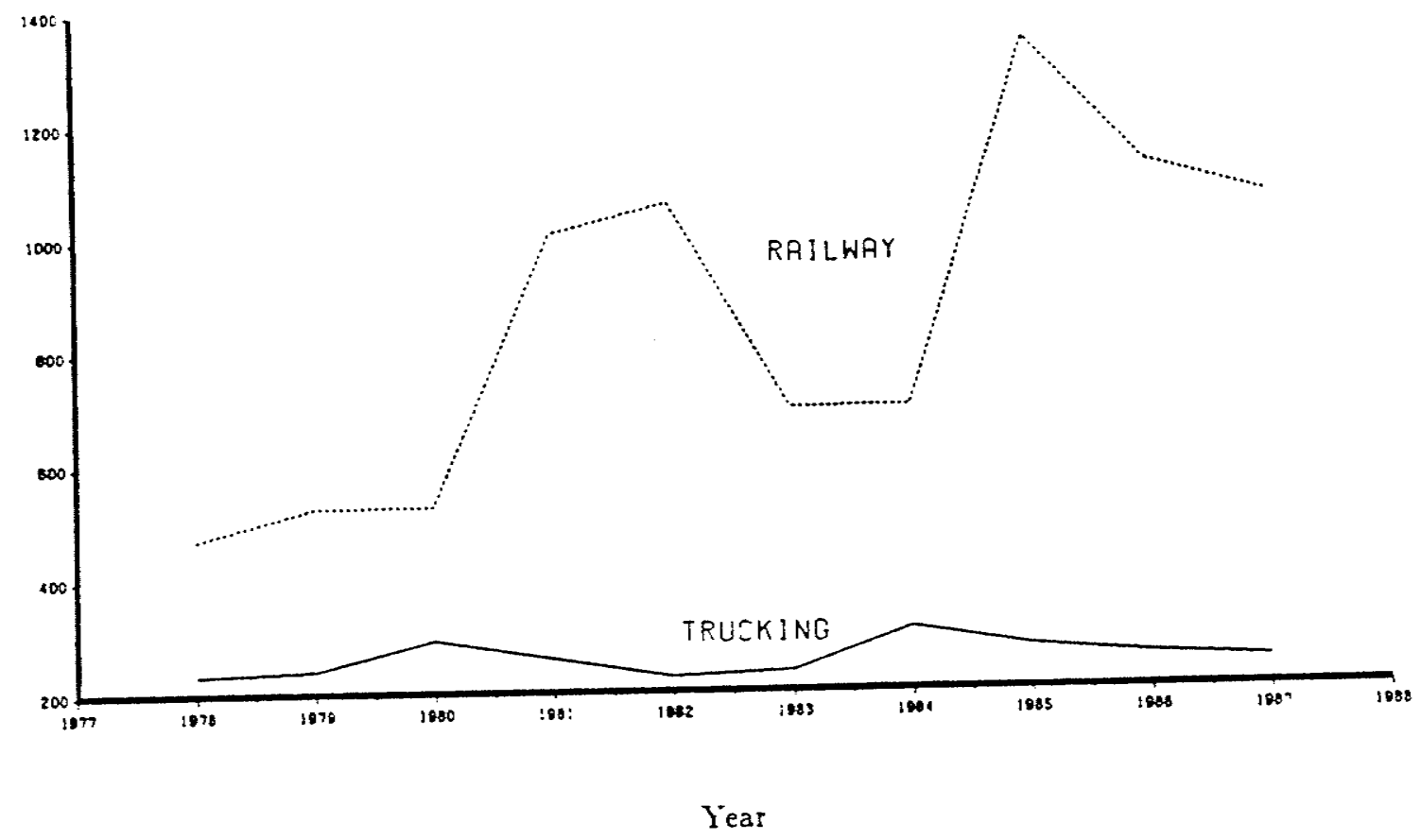

Figure 4.1 $i$ Railway vs. Trucking freight Transportation Interprovincial Tonnage From Saskatchewan to Alberta Tonnage ('000)

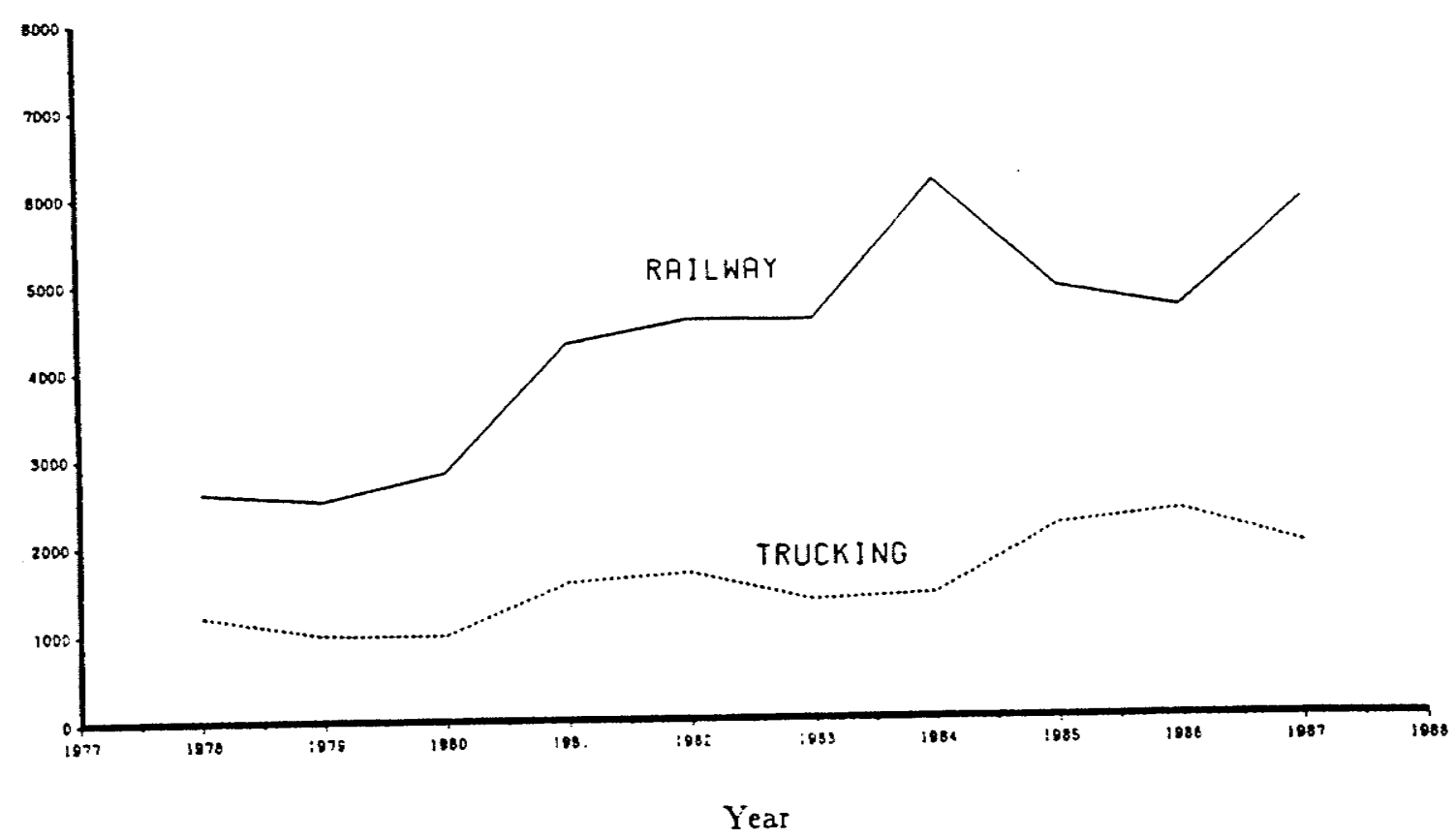

Figure 4.18 Railway vs. Trucking freight Transportation Interprovincial Tonnage From Saskatchewan to the Other Central and Western Provinces 
Table 4.10 Railway Tonnage $\left(\times 10^{3} t\right)$ Moved From Alberta to the Other Western and Central Provinces 1978 - 1987

\begin{tabular}{ccccccc}
\hline Year & Qué. & Ont. & Man. & Sask. & B.C. & Total \\
\hline 1978 & 505 & 680 & 527 & 967 & 1634 & 4313 \\
1979 & 506 & 1008 & 538 & 600 & 1709 & 4361 \\
1980 & 496 & 1092 & 529 & 479 & 2489 & 5085 \\
1981 & 630 & 2052 & 563 & 468 & 2713 & 6426 \\
1982 & 555 & 2318 & 487 & 344 & 2214 & 5918 \\
1983 & 603 & 2556 & 714 & 618 & 2742 & 7233 \\
1984 & 668 & 3185 & 864 & 608 & 3089 & 8414 \\
1985 & 748 & 2773 & 909 & 548 & 2975 & 7953 \\
1986 & 726 & 2772 & 901 & 525 & 2905 & 7829 \\
1987 & 791 & 3252 & 740 & 531 & 3198 & 8512 \\
\hline
\end{tabular}

Table 4.11 Trucking Tonnage $\left(\times 10^{3} t\right)$ Moved From Alberta to the Other Western and Central Provinces 1978 - 1987

\begin{tabular}{ccccccc}
\hline Year & Qué. & Ont. & Man. & Sask. & B.C. & Total \\
\hline 1978 & 105 & 98 & 232 & 643 & 1455 & 2533 \\
1979 & 167 & 164 & 275 & 862 & 1664 & 3132 \\
1980 & 63 & 112 & 227 & 1016 & 2040 & 3458 \\
1981 & 91 & 129 & 366 & 1275 & 1971 & 3832 \\
1982 & 100 & 192 & 343 & 1522 & 1410 & 3567 \\
1983 & 100 & 254 & 353 & 1577 & 1595 & 3779 \\
1984 & 105 & 224 & 438 & 1482 & 1631 & 3880 \\
1985 & 86 & 222 & 437 & 1671 & 1721 & 4137 \\
1986 & 106 & 280 & 644 & 1586 & 1741 & 4357 \\
1987 & 119 & 341 & 690 & 1440 & 2152 & 4742 \\
\hline
\end{tabular}


Tonrage (1000)

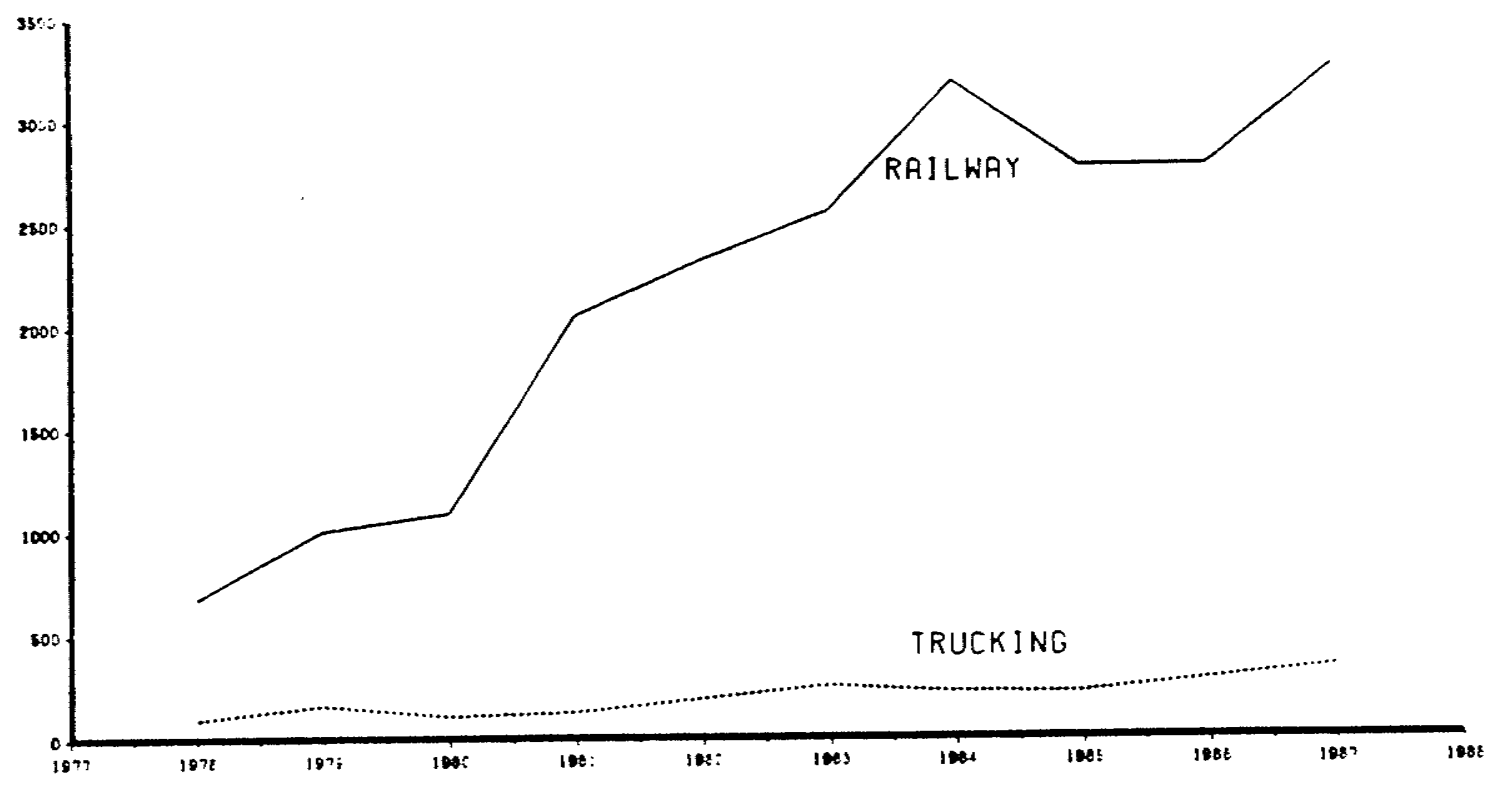

Yea:

Figure 4.19 Railway $\imath$. Trucking freight Transportation

Interprovincial Tonnage From Alberta to Ontario

Tonnage ('000)

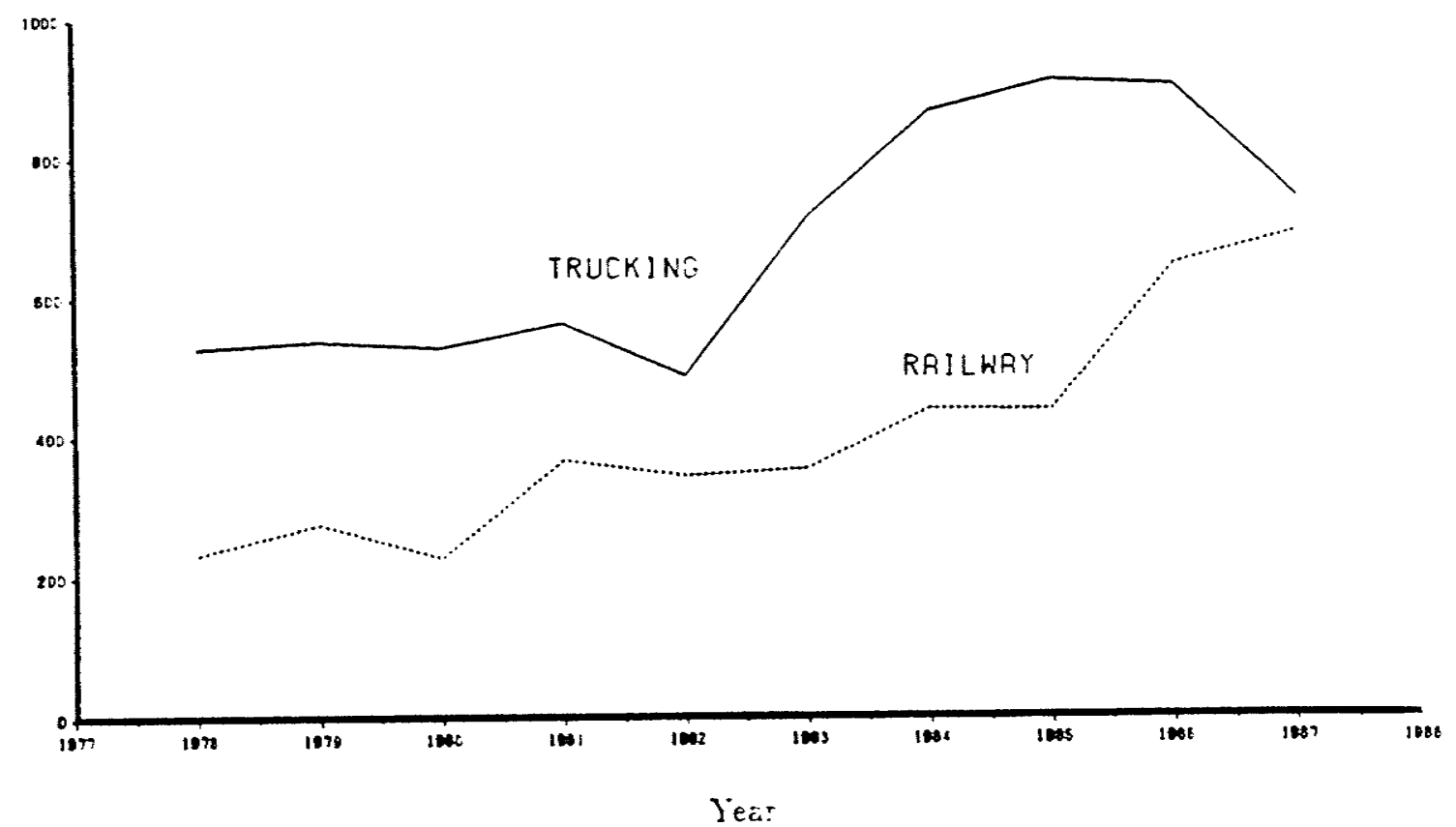

Figure 4.20 Railway $v s$. Trucking freight Transportation

Interprovincial Tonnage From Alberta to Manitoba 
Tonnage (1000),

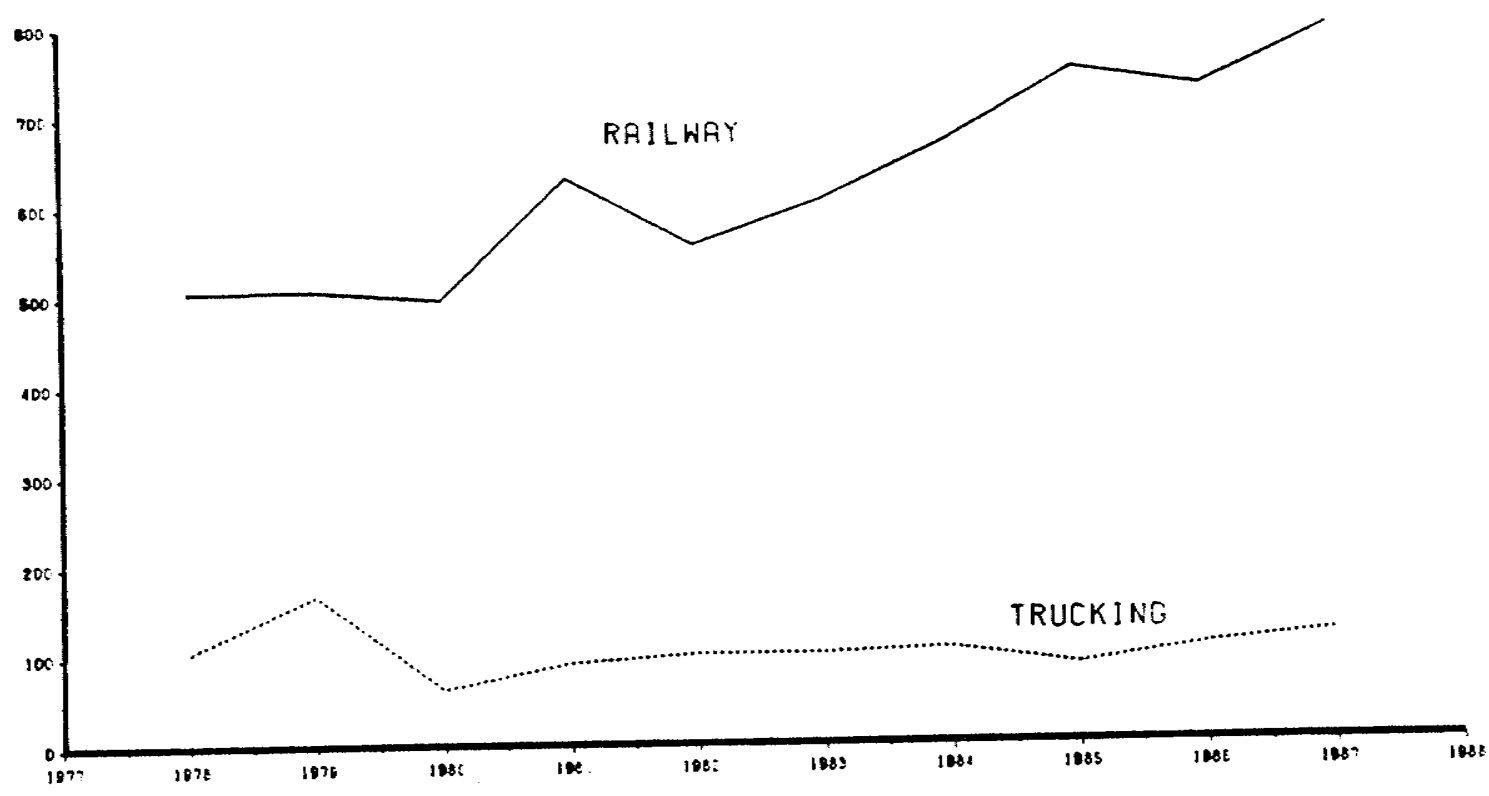

lè̃:

Figure 4.21 Railway vs . Trucking freight Transportation Interprovincial Tonnage From Alberta to Québec

Tonnage ('000(i)

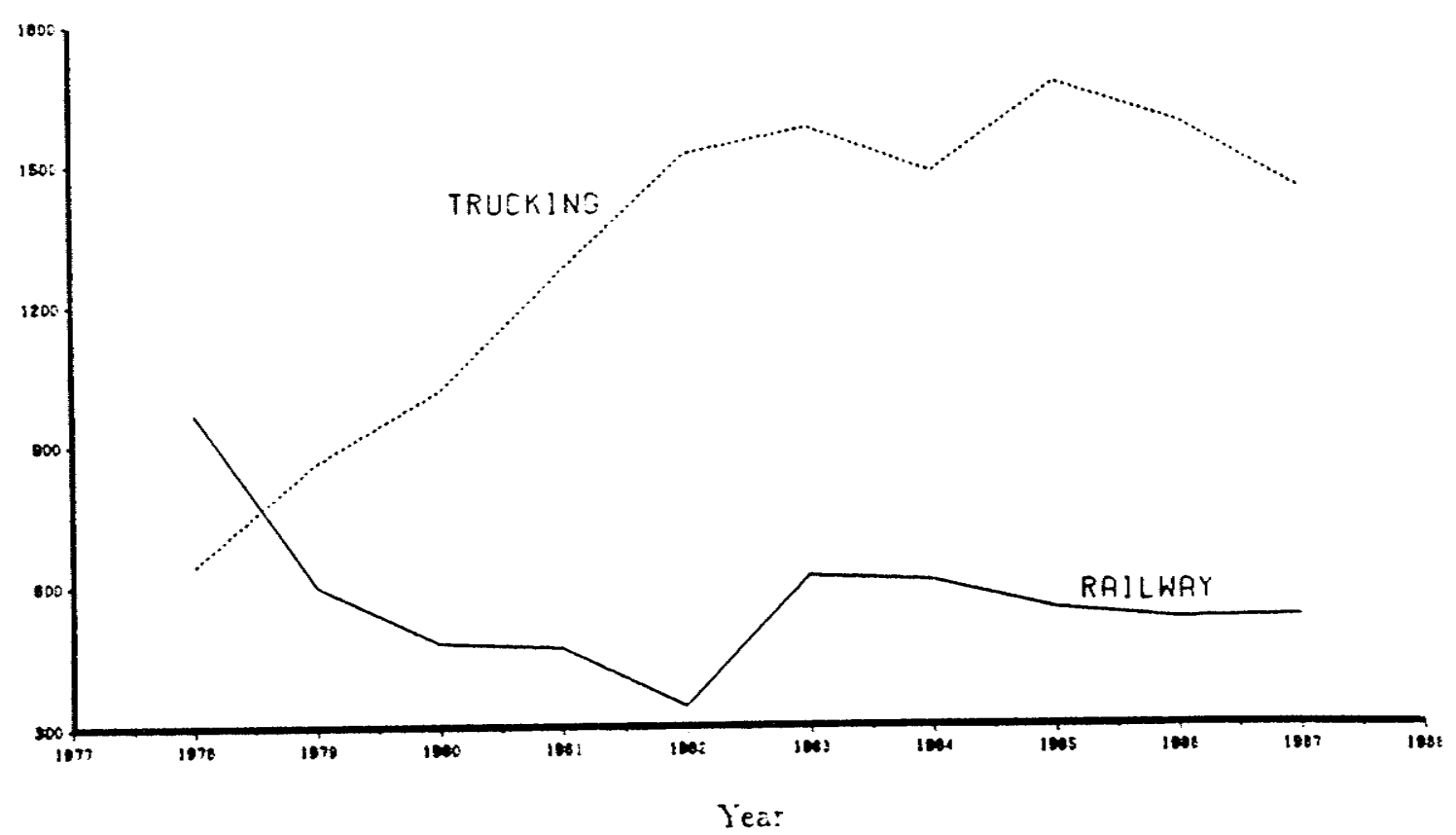

Figure 4.22 Railway $v s$. Trucking freight Transportation Interprovincial Tonnage From Alberta to Saskatcheawn 
Table 4.12 Railway Tonnage $\left(\times 10^{3} t\right)$ Moved From British Columbia to the Other Western and Central Provinces 1978 - 1987

\begin{tabular}{ccccccc}
\hline Year & Qué. & Ont. & Man. & Sask. & Alta. & Total \\
\hline 1978 & 425 & 1005 & 353 & 303 & 2089 & 4175 \\
1979 & 381 & 1382 & 304 & 308 & 1964 & 4339 \\
1980 & 381 & 1305 & 299 & 253 & 2096 & 4334 \\
1981 & 683 & 1387 & -323 & 209 & 2065 & 4667 \\
1982 & 689 & 1638 & 260 & 136 & 1392 & 4115 \\
1983 & 810 & 1752 & 271 & 136 & 1417 & 4386 \\
1984 & 975 & 2328 & 320 & 123 & 1685 & 5431 \\
1985 & 1159 & 2387 & 385 & 115 & 1600 & 5646 \\
1986 & 1175 & 2626 & 368 & 109 & 1595 & 5873 \\
1987 & 1180 & 3268 & 265 & 96 & 1660 & 6469 \\
\hline
\end{tabular}

Table 4.13 Trucking Tonnage $\left(\times 10^{3} t\right)$ Moved From British Columbia to the Other Western and Central Provinces 1978 - 1987

\begin{tabular}{ccccccc}
\hline Year & Qué. & Ont. & Man. & Sask. & Alta. & Total \\
\hline 1978 & 49 & 113 & 102 & 105 & 1295 & 1664 \\
1979 & 42 & 68 & 78 & 164 & 1509 & 1861 \\
1980 & 27 & 77 & 67 & 160 & 1948 & 2279 \\
1981 & 26 & 154 & 108 & 233 & 1523 & 1944 \\
1982 & 56 & 134 & 95 & 143 & 1380 & 1808 \\
1983 & 37 & 128 & 100 & 203 & 1643 & 2111 \\
1984 & 45 & 170 & 132 & 190 & 1739 & 2276 \\
1985 & 61 & 154 & 162 & 229 & 1925 & 2531 \\
1986 & 50 & 154 & 191 & 262 & 1679 & 2336 \\
1987 & 60 & 167 & 225 & 212 & 2269 & 2933 \\
\hline
\end{tabular}


Tonnage ('000)

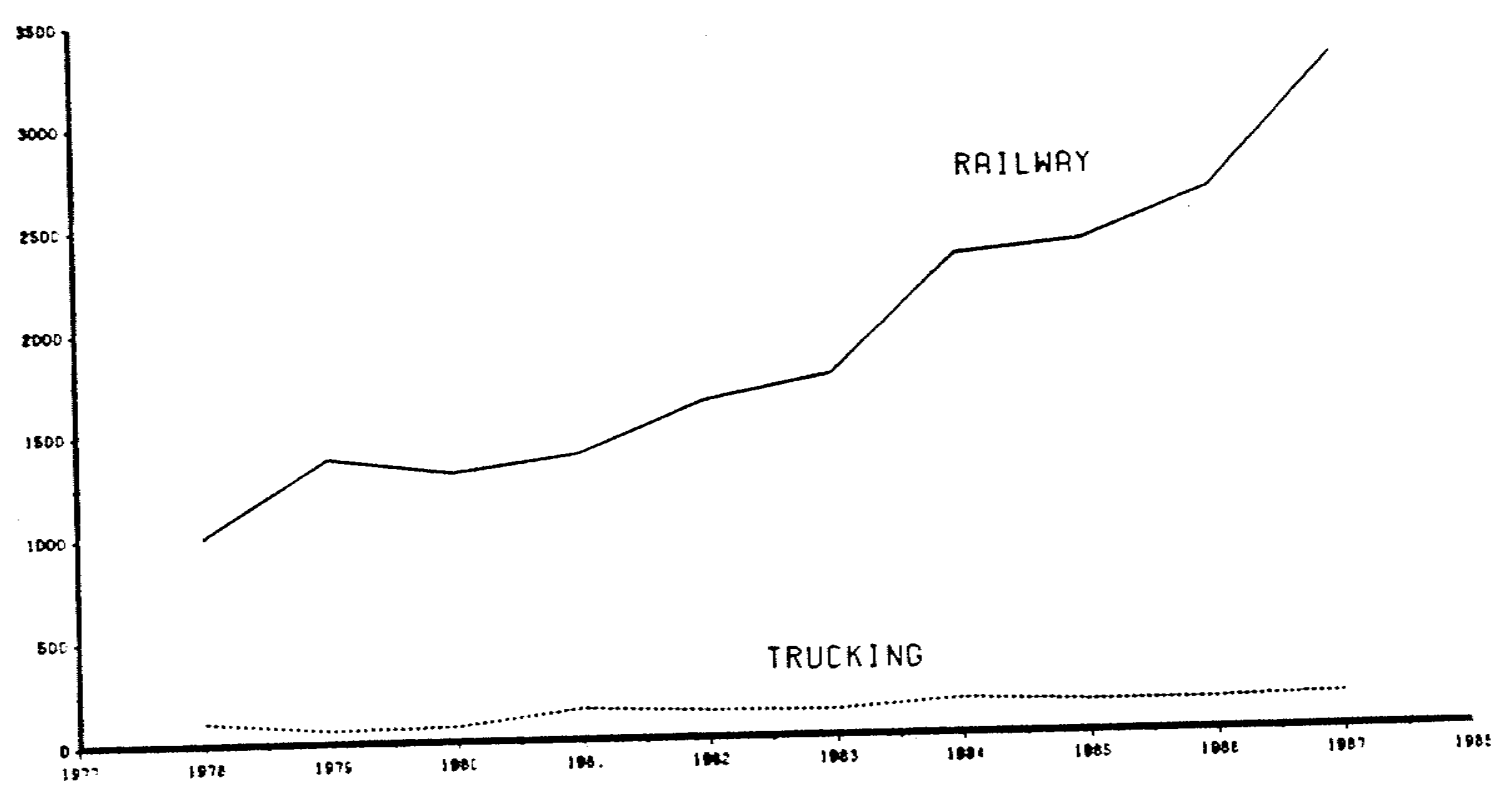

lea:

Figure 4.23 Railway vs. Trucking freight Transportation Interprovincial Tonnage From British Columbia to Ontario

Tonrage ('000)

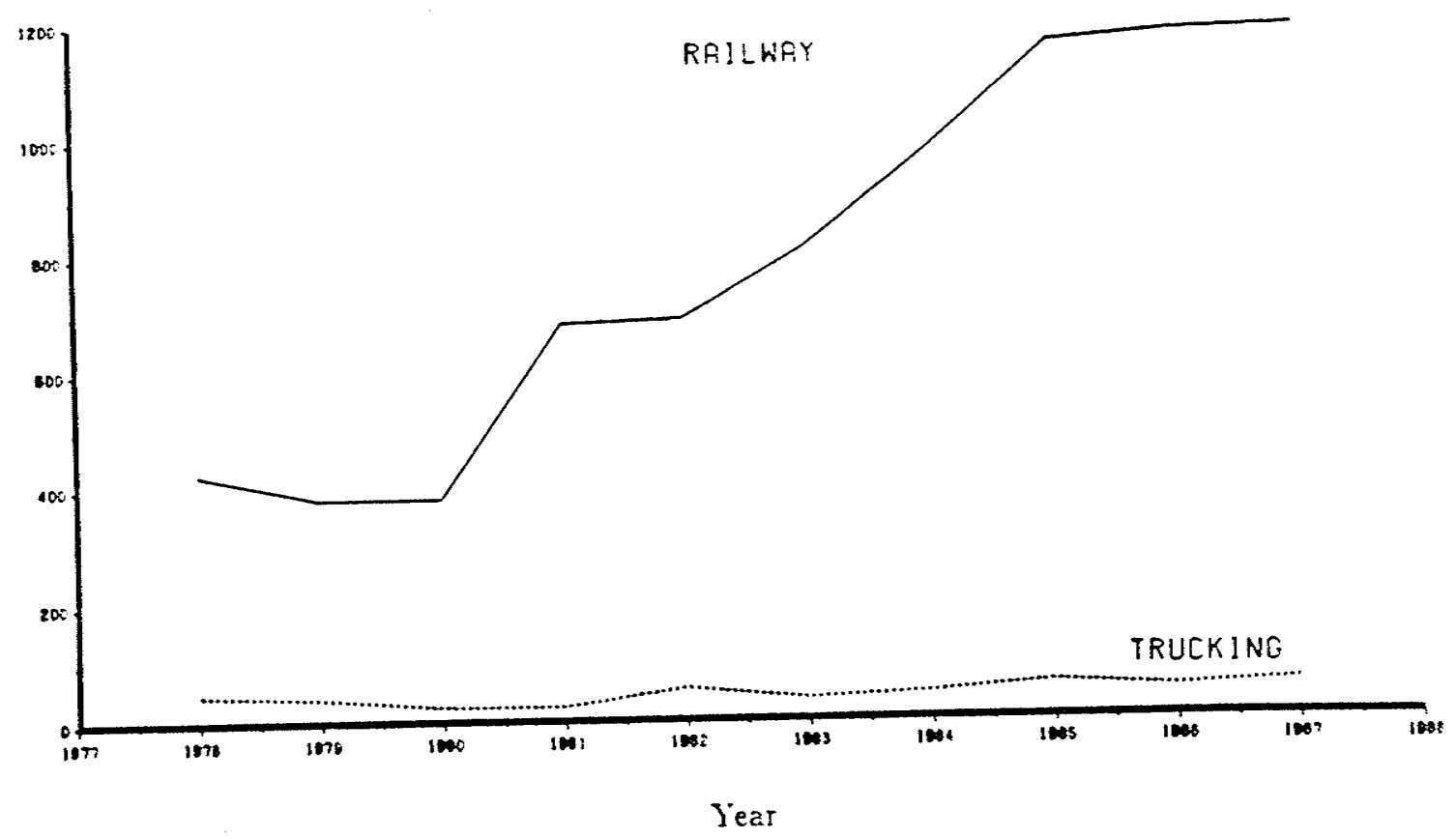

Figure 4.24 Railway vs . Trucking freight Transportation Interprovincial Tonnage From British Columbia to Québec 
Tonnage ('000)

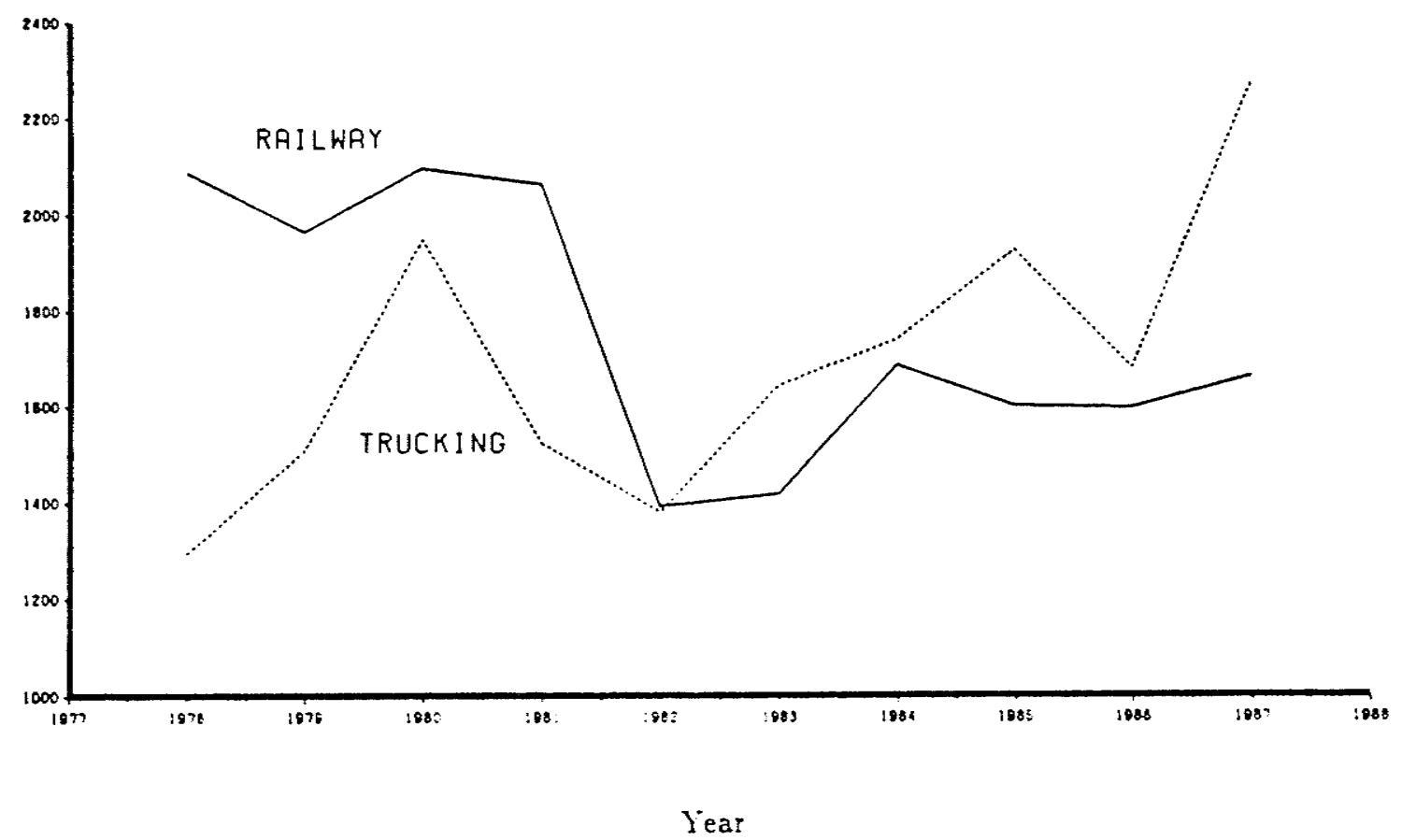

Figure 4.25 Railway $v s$. Trucking freight Transportation Interprov: ncial Tonnage From British Celumbia to Alberta

Tonnage ('000)

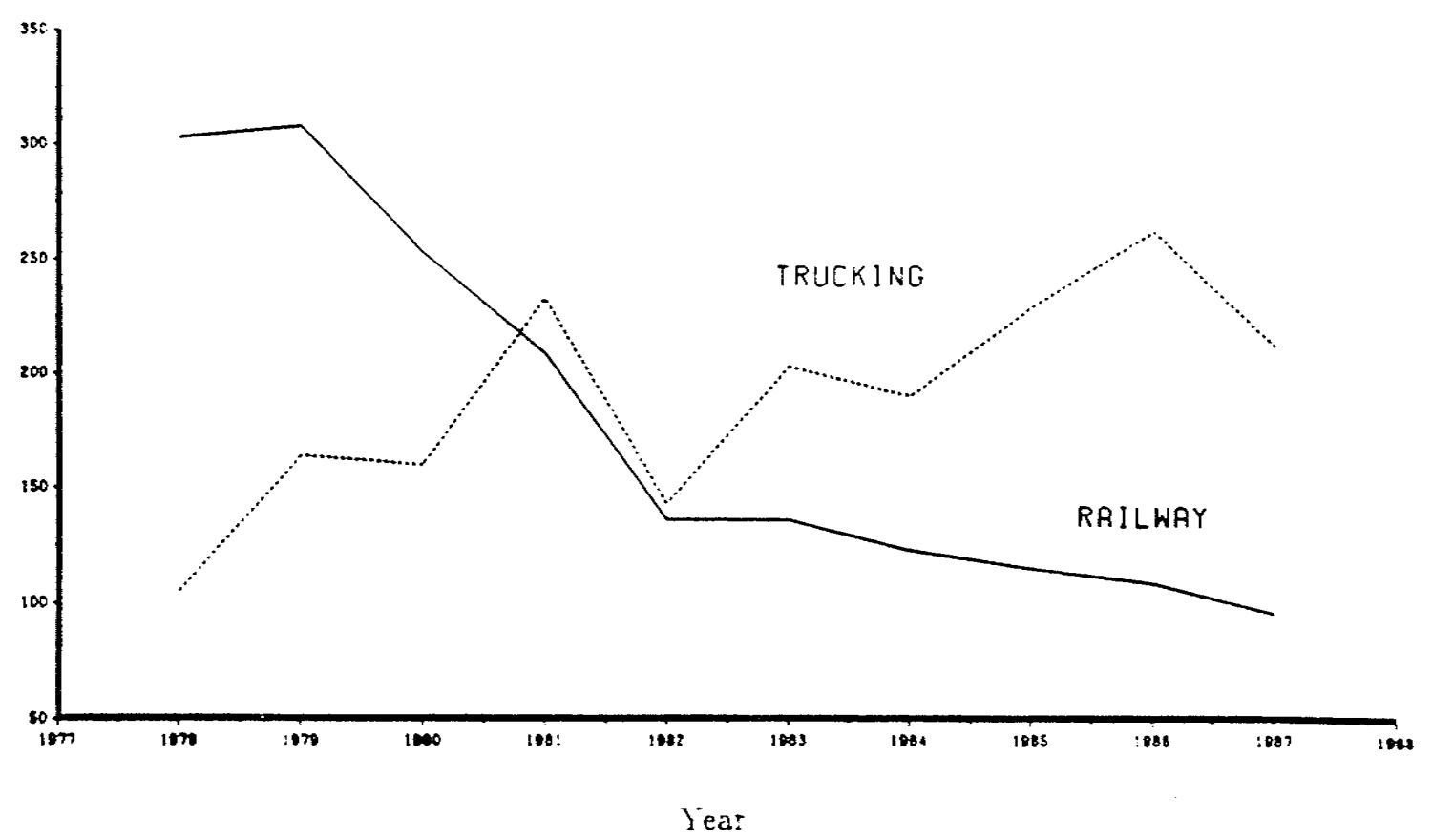

Figure 4.26 Railway vs . Trucking freight Transportation Interprovincial Tonnage From British Columbia to Saskatchewan 


\subsection{2॰ Competition/Modal Split by Commdity Type}

The average annual tonnage moved within the four commodity sections is significant for both the railway and trucking modes. While both rail and truck modes have increased their interprovincial freight volumes from year to year, over the past ten years rail has grown at a slower pace than trucking in three of the four commodity sections. FMI rail volume has increased more rapidly than truck volume, the opposite of what has been observed for the FFB\&T, CMI and EPI sections. Generally, the observation often made is that trucking has captured a greater share of the more valuable commodities market over shorter distances (0-1500 kilometers), leaving the less valuable, lower revenue bulk commodities, over longer distances, to the railways. For the EPI and FFB\&T commodity sections, trucking carries more than rail over shorter distances but remains competitive over longer distances. For the commodity classification FMI, the competition between the two modes is high, especially over short distances. Generally, for the four commodity sections freight, the cost per tonne per kilometer to ship freight reduces as distances increase for both railway and trucking modes, (Figures 4.27 through 4.30). However, it reduces at a much faster rate for rail than for trucking. As a result, over medium and longer range distances the rail industry dominates in the volume and percentage of freight carried. For the commodity section CMI, rail dominates over all distances. Modal split among commodity classifications (data averaged over the years 1983, '84, '86, and '87) is illustrated in Table 4.14.

The above observation can also be seen from the tables presented in appendix 4. In these tables the rail/truck modal split by commodity section for the years 1983, 1984, 1986 and 1987 is presented using tonnage originated at Ontario and transported to the other central and western provinces. Examples of short, medium and long freight haulage, for the four commodity sections, are depicted in figures and presented in appendix 5. Tonnage originated at Ontario and transported to Québec, Manitoba, Alberta and British Columbia is used to genarate those figures. 
Rate(s:i)

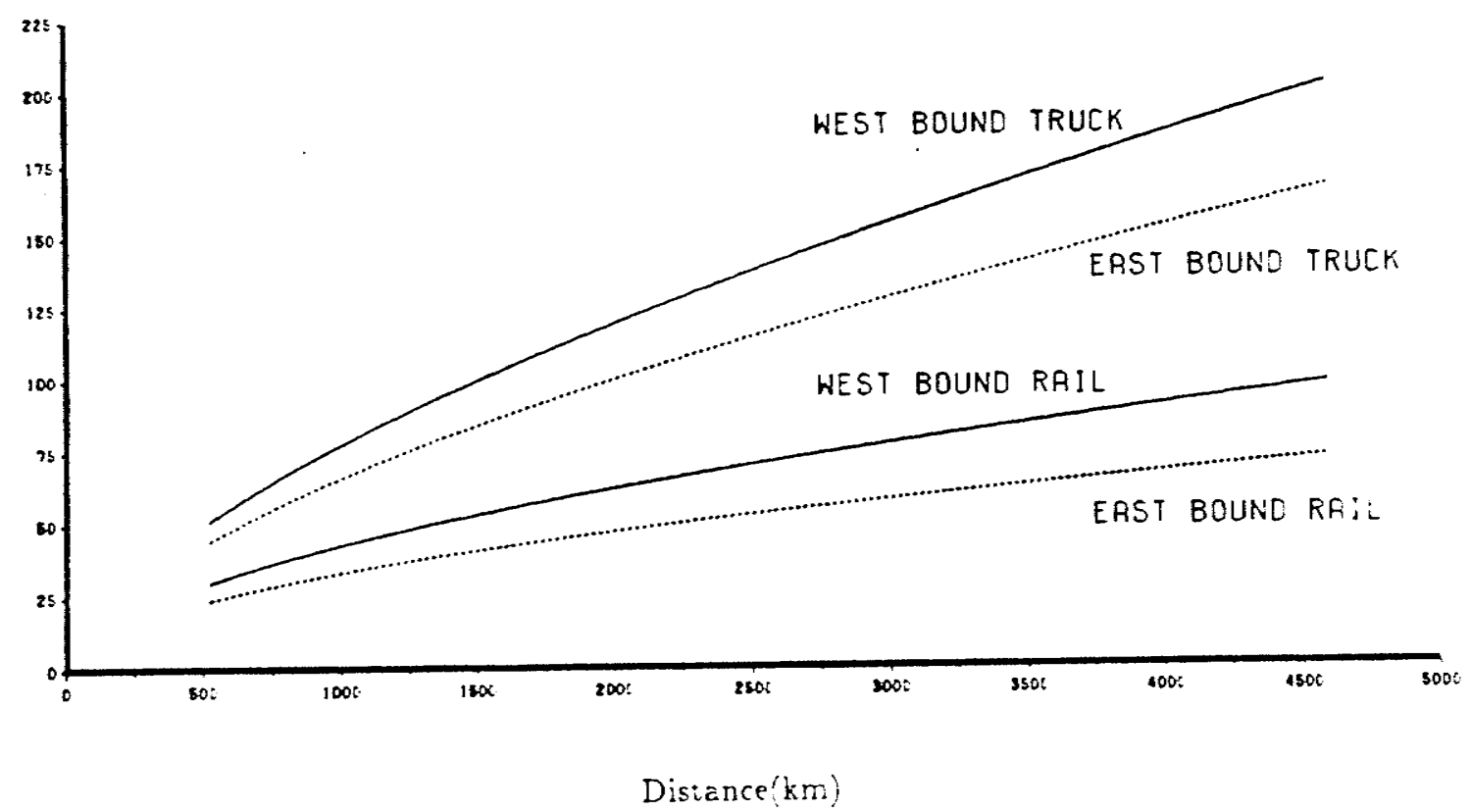

Figure 4.2 FFB\&T: Distance vs. Rate by Mode and Direction

Rate(s/t)

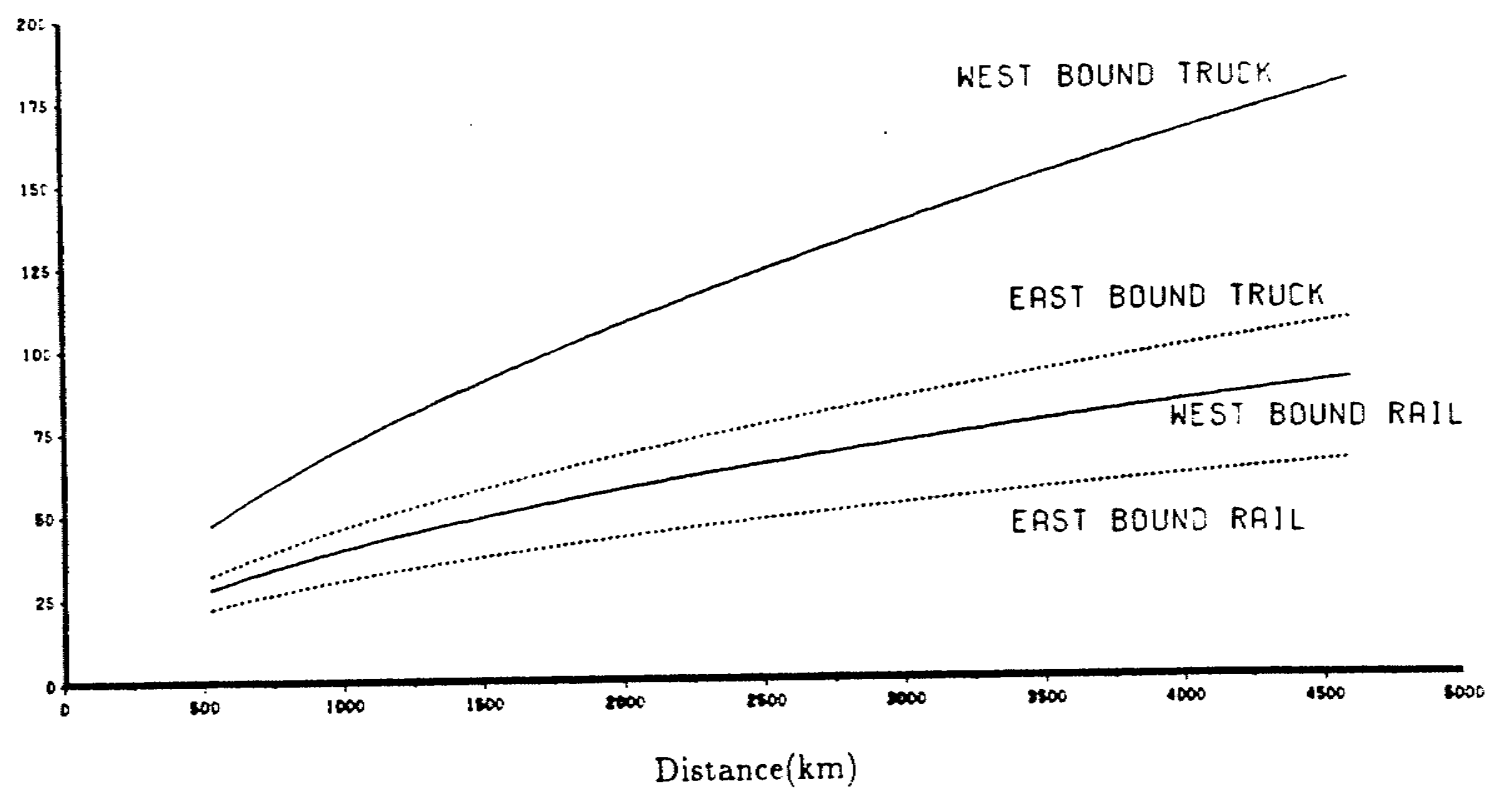

Figure 4.28 CMI: Distance vs. Rate by Mode and Direction 
Rate $(s / t)$

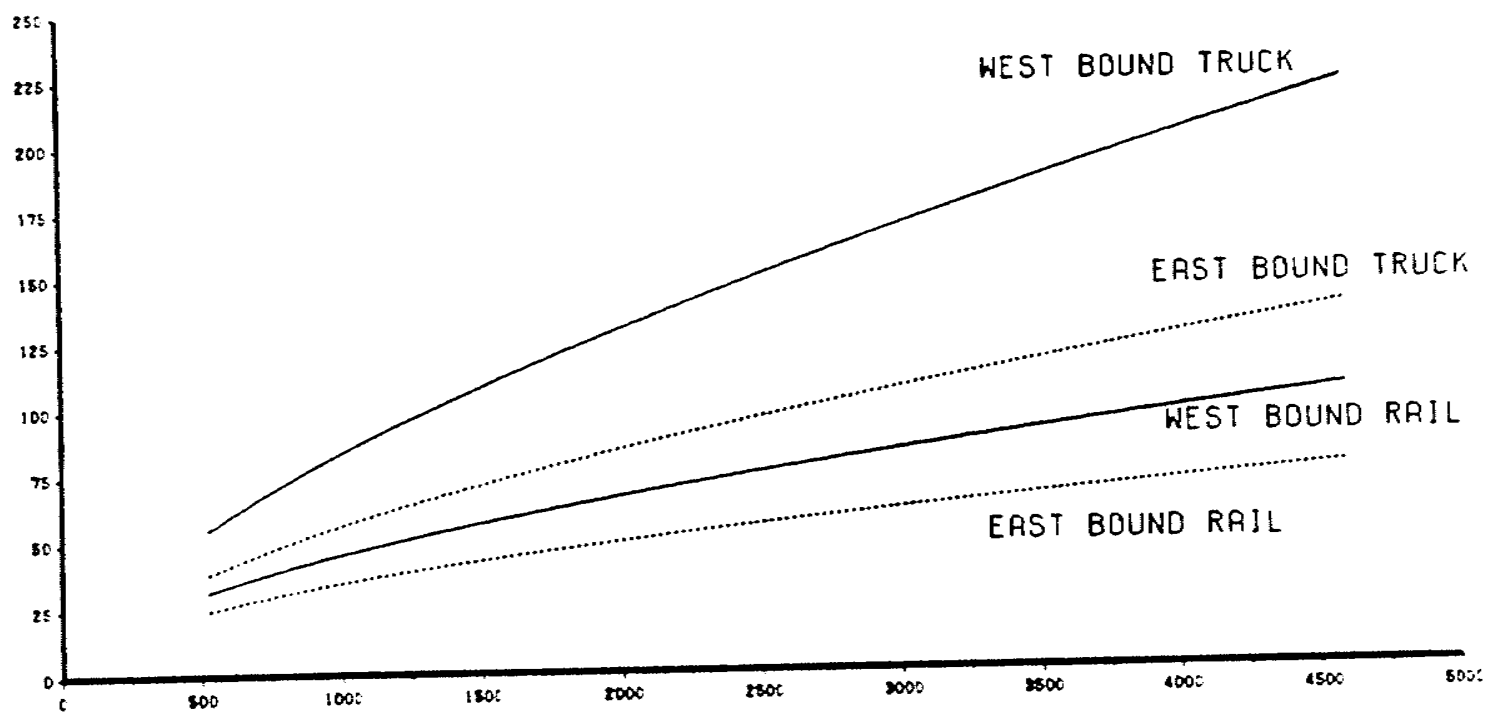

Disiance $\mathrm{km}$ )

Figure 4.29 FMI: Distance vs. Rate

by Mode and Direction

$\operatorname{Rate}(\varepsilon / t)$

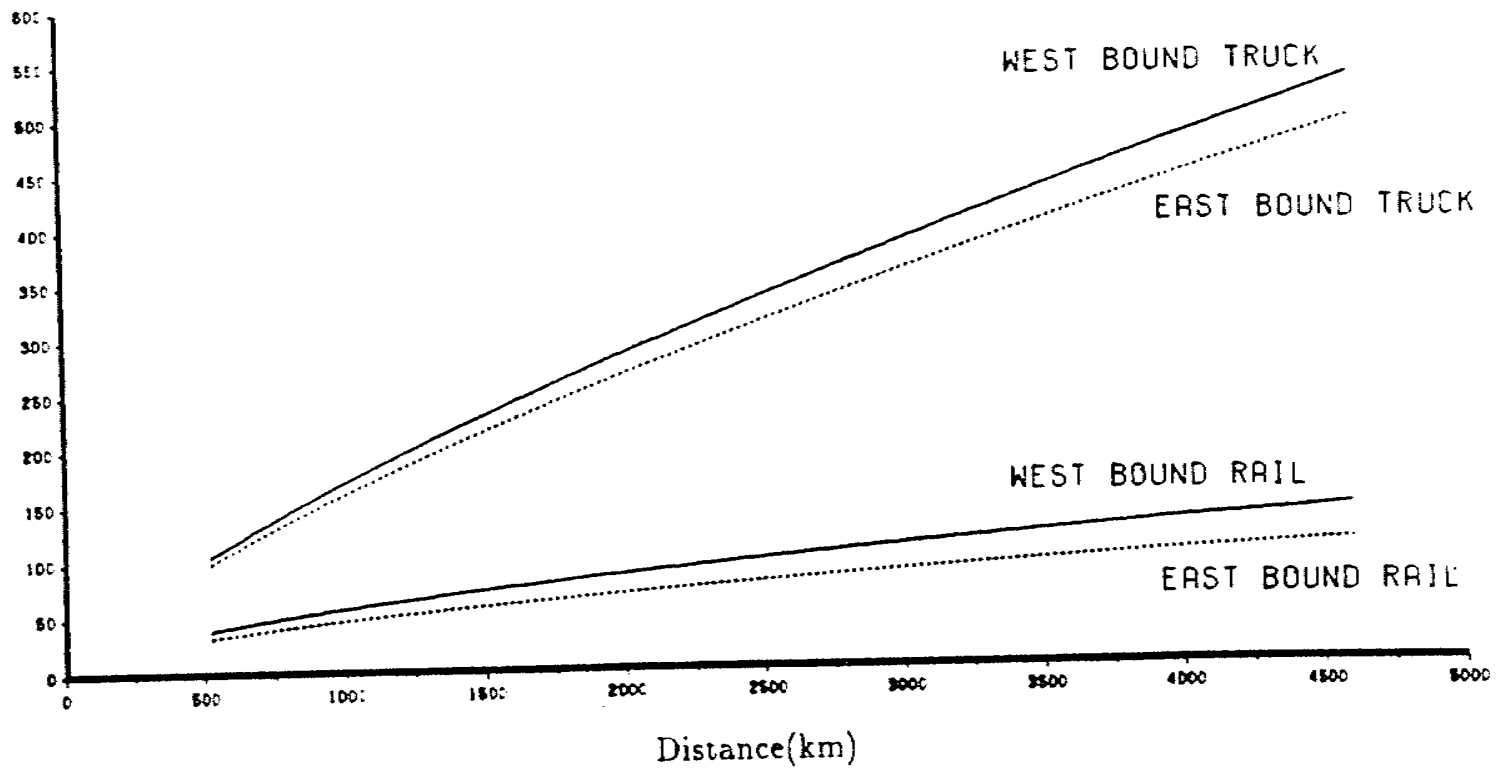

Figure 4.30 EPI: Distance vs. Rate

by Mode and Direction 
Table 4.14 Truck/Rail Modal Split by Commodity Section Over Short, Medium and Long Ranges (\%)

\begin{tabular}{rrrrrr}
\hline Range & Mode & & $\begin{array}{c}\text { Food } \\
\text { mat. }\end{array}$ & $\begin{array}{c}\text { Fabr. } \\
\text { mat. }\end{array}$ & $\begin{array}{r}\text { End } \\
\text { prod. }\end{array}$ \\
\hline under & Rail & $43 \%$ & $81 \%$ & $51 \%$ & $18 \%$ \\
$1,500 \mathrm{~km}$ & Truck & $57 \%$ & $19 \%$ & $49 \%$ & $82 \%$ \\
$1,500 \mathrm{to}$ & Rail & $75 \%$ & $80 \%$ & $87 \%$ & $46 \%$ \\
$3,000 \mathrm{~km}$ & Truck & $25 \%$ & $20 \%$ & $13 \%$ & $54 \%$ \\
over & Rail & $85 \%$ & $93 \%$ & $91 \%$ & $53 \%$ \\
$3,000 \mathrm{~km}$ & Truck & $15 \%$ & $07 \%$ & $09 \%$ & $47 \%$ \\
\hline
\end{tabular}

\subsubsection{1 $\diamond$ FFB\&T: Commodity Movement and Composition}

The types and nature of "Food, feed, beverages and tobacco" class freight carried by the railways differs sharply with the trucking mode. For rail, this section is composed almost exclusively (more than 90\%) by wheat, dairy produce, oats, rice, wheat flour, barley, and soybeans. For trucks, the variety of freight carried under the description FFB\&T is largely food preparations, dairy products, cereal grains, fruit and vegetables such as apples, bananas, grapes, watermelons, cantaloupes, peaches, pears, and tomatoes, and other freight such as meat and fish, cheese, beverages, and tobacco and cigarettes.

In terms of the rail/truck competition in this commodity classification, the data shows that the bulk of the railborne freight (65.0\%) is not subject to significant competition by truck. Similarly, about $60.0 \%$ of the FFB\&T commodity carried by truck (food preparations, cereal, vegetables, alcoholic beverages, meat and poultry, fruits and tobacco) is not subject to competition by rail. Tables 4.15 and 4.16 show the link-by-link share of this commodity for 1987 interprovincial volume for rail and truck respectively. Tables of the same nature for the same purpose, for both modes for the year 1986 are presented in Appendix 6. The data they contain covers all four commodity sections. It is clear that the principal railway links in this commodity are those of Saskatchewan to Ontario (28\%), Saskatchewan to British Columbia (22\%), 
and Alberta to British Columbia (22\%). The major destinations of railway food tonnage are British Columbia (47\%) and Ontario (44\%). This tonnage is primarily wheat transported for marine export.

It would appear however, that trucking volume is more scattered between over the links with major traffic movement between Québec and Ontario 38\%. The type of freight and the percentages of the composition of this commodity section for both rail and truck is detailed in Tables 4.17 and 4.18 respectively.

\section{Table 4.15 FFB\&T Link-by-Link Share of Interprovincial} Railway Volume 1987 (\%)

\begin{tabular}{lcccccc}
\hline$O: \backslash D:$ & Que. & Ont. Man. & Sask. & Alta B.C. \\
\hline Que. & & - & - & - & - & - \\
Ont. & 4.0 & & 1.0 & - & 1.0 & 1.0 \\
Man. & 1.0 & 13.0 & & - & - & 2.0 \\
Sask. & - & 28.0 & 1.0 & - & - & 22.0 \\
Alta & - & 3.0 & 1.0 & - & & 22.0 \\
B.C. & - & - & - & - & - \\
\hline
\end{tabular}

Table 4.16 FFB\&T Link-by-Link Share of Interprovincial Trucking Volume 1987 (\%)

\begin{tabular}{|c|c|c|c|c|c|c|}
\hline$O: \backslash D:$ & Que. & Ont. & Man. & Sask. & Alto & B.C \\
\hline Que. & & 15.4 & 0.7 & - & 0.9 & 0.6 \\
\hline Ont. & 23.0 & & 2.2 & 0.5 & 2.5 & 1.3 \\
\hline Man. & 1.5 & 3.5 & & 5.2 & 2.8 & 1.7 \\
\hline Sask. & 0.1 & 0.3 & 1.4 & - & 3.7 & 1.2 \\
\hline Alta & 1.4 & 1.7 & 2.8 & 2.5 & & 12.4 \\
\hline B.C. & 0.4 & 0.8 & 2.7 & $1: 1$ & 5.6 & \\
\hline
\end{tabular}

\subsubsection{2 $\diamond$ CMI: Commodity Movement and Composition}

The commodity section 'Crude materials, inedible' (CMI) was the largest component of rail tonnage in 1987 , comprising $48.0 \%$ and $12.9 \%$ of rail and truck tonnage 
Table 4.17 Railway Food, Feed, Beverages and Tobacco Composition

\begin{tabular}{lrc}
\hline Commodity type & & cum. \\
& (\%) & (\%) \\
\hline Wheat & $65.0 \%$ & $65.0 \%$ \\
Dairy produce, n.e.s., ${ }^{1}$ eggs and honey & $19.0 \%$ & $84.0 \%$ \\
Rice & $1.7 \%$ & $85.7 \%$ \\
Oats & $1.4 \%$ & $87.1 \%$ \\
Wheat flour & $1.3 \%$ & $88.4 \%$ \\
Barley & $1.2 \%$ & $89.9 \%$ \\
Soybean & $1.2 \%$ & $91.1 \%$ \\
Food preparation & $1.1 \%$ & $92.1 \%$ \\
Vegetables and preparations, n.e.s. & $0.9 \%$ & $93.0 \%$ \\
Feed of vegetable origin, n.e.s. & $0.8 \%$ & $93.8 \%$ \\
Malt and malt flour & $0.8 \%$ & $94.6 \%$ \\
Ground cereals and by-products, n.e.s. & $0.7 \%$ & $95.3 \%$ \\
Wheat bran, shorts and middlings & $0.6 \%$ & $95.9 \%$ \\
Hay, forage and straw & $0.5 \%$ & $96.4 \%$ \\
Fruit Juice Concentrates, frozen & $0.3 \%$ & $96.7 \%$ \\
\hline
\end{tabular}

${ }^{1}$ n.e.s. - not elsewhere specified

respectively. While about half of each mode's share is captive to that mode, there exists competition between these modes for traffic in this commodity section. The link from Ontario to Québec, for example, constituted $5.2 \%$ and $17.7 \%$ of interprovincial tonnage for rail and truck repectively. As can be seen in Tables 4.19 and 4.20 , the other competitive link is from Saskatchewan to Manitoba. The data also suggests that there is competition over short haul links (with the exception of the Alberta to British Columbia link where rail carries about $50 \%$ of its interprovincial tonnage). Longer haul ranges are dominated by rail. Examination of the 1986 data contained in the tables presented in Appendix 6 reveal the same observation.

The types and nature of the commodity classification "crude materials, inedible" carried by rail and truck is detailed in Tables 4.21 and 4.22 . From these tables it is clear that iron and bituminous coal constitute more than $50 \%$ of the rail share of this commodity section and that they are not carried by truck. Sand, gravel and crude stone constitute about $38 \%$ of this commodity section's truck freight and are 
Table 4.18 Trucking Food, Feed, Beverages and Tobacco Composition

\begin{tabular}{lrc}
\hline Commodity type & $(\%)$ & $\begin{array}{c}\text { cum. } \\
(\%)\end{array}$ \\
\hline Other food preparations & $25.8 \%$ & $25.8 \%$ \\
Dairy products, & $18.6 \%$ & $44.4 \%$ \\
Cereal grains, unmilled & $9.6 \%$ & $54.4 \%$ \\
Vegetables, fresh or chilled & $7.2 \%$ & $61.2 \%$ \\
Fermented alcoliolic beverages & $4.1 \%$ & $65.3 \%$ \\
Meat (exept poultry), fresh, chilled or frozen & $4.1 \%$ & $69.4 \%$ \\
Non-alcoholic beverages & $3.8 \%$ & $73.2 \%$ \\
Distilled alcoholic beverages & $2.8 \%$ & $76.0 \%$ \\
Sugar, molasses and syrups & $2.8 \%$ & $78.8 \%$ \\
Canned food, n.e.s. & $2.0 \%$ & $80.8 \%$ \\
Other bakery products & $1.9 \%$ & $82.7 \%$ \\
Cereal grains, milled & $1.8 \%$ & $84.5 \%$ \\
Complete feed & $1.5 \%$ & $86.0 \%$ \\
Poultry meat, fresh, chilled or frozen & $1.0 \%$ & $87.0 \%$ \\
Fish, whole (round) or dressed & $1.0 \%$ & $88.0 \%$ \\
Fruit juice concentrates & $0.9 \%$ & $88.9 \%$ \\
Fruits and berries, fresh or chilled & $0.8 \%$ & $89.7 \%$ \\
Sugar preparations & $0.7 \%$ & $8 \mathrm{c} .6 \%$ \\
Tobacco products, manufactured & $0.6 \%$ & $90.2 \%$ \\
Meat prep. and ready-cooked meat & $0.5 \%$ & $90.7 \%$ \\
\hline
\end{tabular}

1 n.e.s. - not elsewhere specified

not shipped by rail.

\subsubsection{3 $\diamond$ FMI: Commodity Movement and Composition}

The types of freight composing the majority of fabricated materials moved by the railway and trucking industry are similar, showing the two modes to be very competitive in this classification.

Tables 4.23 and 4.24 show clearly the existing competition in this commodity classification. For example, the highest competition can be noticed in the movement of this commodity between the Québec and Ontario provinces. Similarly, The CMI movement from Alberta to British Columbia, constituting $12.9 \%$ and $10.2 \%$ of rail and trucking interprovincial CMI tonnage, is also a highly competitive market. The 
Table 4.19 CMI Link-by-Link Share of Interprovincial Railway Volume 1987 (\%)

\begin{tabular}{lccccccc}
\hline$O: \backslash D:$ & Que. & Ont. & Man. & Sask. & Alta & B.C. \\
\hline Que. & & 1.0 & - & - & - & - \\
Ont. & 5.2 & & - & 0.3 & 0.2 & - \\
Man. & 0.2 & 2.1 & & 2.0 & 0.3 & 1.4 \\
Sask. & 0.2 & 7.9 & 2.8 & & - & 4.6 \\
Alta & 0.3 & 7.5 & 0.2 & 1.7 & & 49 \\
B.C. & - & 6.7 & 0.4 & - & 5.4 \\
\hline \multicolumn{7}{c}{} \\
\hline \multicolumn{7}{c}{ less than $0.05 \%}$.
\end{tabular}

Table 4.20 CMI Link-by-Link Share of Interprovincial Trucking Volume 1987 (\%)

\begin{tabular}{|c|c|c|c|c|c|c|}
\hline$O: \backslash D:$ & Que. & Ont. & Man. & Sask. & Alta & B.C \\
\hline Que. & & 10.2 & - & - & 0.2 & - \\
\hline Ont. & 17.7 & & 0.5 & 0.2 & 0.2 & 0.2 \\
\hline Man. & 0.2 & 14.2 & & 2.2 & 0.6 & - \\
\hline Sask. & - & 0.4 & 4.9 & - & 14.9 & 1.2 \\
\hline Alta & 0.1 & 0.6 & 6.5 & 4.4 & & 4.0 \\
\hline B.C. & 0.1 & 0.2 & 0.8 & 0.2 & 15.2 & \\
\hline
\end{tabular}

percentages of both modes are equal, indicating high competition, for the Manitoba to Ontario link, $2.3 \%$. Inspecting the movement between most of the adjacent provinces reveals that there is competiton between the two modes. Conversley, in longer haulage from Saskatchewan to Britsh Columbia and to Ontario, the rail predominance is clear.

The fabricated materials moved by both rail and truck are characterized by numerous commodity types constituting small percentages of the total tonnage moved. However, a number of similar commodity types are moved by both modes. These include: lumber, woodpulp and other wood fabricated materials; newsprint and other paper for printing; fertilizers; cement and cement products; fuel oil, gasoline, refined gases, and other petrochemical and coal products; and plate, sheet, and strip steel and other metal fabricated products. 
Table 4.21 Railway Crude Materials Composition

\begin{tabular}{lrc}
\hline Commodity type & $(\%)$ & $\begin{array}{c}\text { cum. } \\
(\%)\end{array}$ \\
\hline Iron ore and concentrates & $31.0 \%$ & $31.0 \%$ \\
Bituminous coal & $24.8 \%$ & $55.8 \%$ \\
Pulpwood chips & $8.2 \%$ & $64.0 \%$ \\
Gypsum & $5.2 \%$ & $69.2 \%$ \\
Liquid sulphur & $4.6 \%$ & $73.8 \%$ \\
Bauxite ore and alumina & $3.1 \%$ & $76.9 \%$ \\
Nickel Copper ores and concentrates & $2.8 \%$ & $79.7 \%$ \\
Limestone, crushed or broken, n.e.s. & $2.7 \%$ & $82.4 \%$ \\
Pulpwoods logs & $2.4 \%$ & $84.8 \%$ \\
Copper ores and concentrates & $1.5 \%$ & $86.3 \%$ \\
Zinc ore and concentrates & $1.5 \%$ & $87.8 \%$ \\
Iron and steel scrap & $1.4 \%$ & $89.2 \%$ \\
Rapeseed & $1.4 \%$ & $90.6 \%$ \\
Lignite coal & $1.3 \%$ & $91.9 \%$ \\
Logs and bolts of wood & $1.0 \%$ & $92.9 \%$ \\
Common salt, rock or bulk & $0.9 \%$ & $93.8 \%$ \\
Phosphate rock & $0.7 \%$ & $94.5 \%$ \\
Lead ore and concentrates & $0.6 \%$ & $95.8 \%$ \\
Flaxseed & $0.5 \%$ & $96.3 \%$ \\
Natural abrasive & $0.4 \%$ & $96.7 \%$ \\
\hline
\end{tabular}

I n.e.s. - not elsewhere specified

Table 4.22 Trucking Crude Materials Composition

\begin{tabular}{|c|c|c|}
\hline Commodity type & $(\%)$ & $\underset{(\%)}{\operatorname{cum} .}$ \\
\hline Sand, gravel \& crude stone & $37.7 \%$ & $37.7 \%$ \\
\hline Pulpwood chips & $21.5 \%$ & $59.2 \%$ \\
\hline Logs and bolts & $8.3 \%$ & $67.5 \%$ \\
\hline Other crude non-metalic & $7.1 \%$ & $74.6 \%$ \\
\hline Crude mineral oil & $5.1 \%$ & $79.7 \%$ \\
\hline Other waste \& scrap materials & $4.7 \%$ & $84.4 \%$ \\
\hline Other metal-bearing ores, concentrates and scraps & $4.4 \%$ & $88.8 \%$ \\
\hline Pulpwood logs & $1.9 \%$ & $90.7 \%$ \\
\hline Nursery \& greenhouse stock \& related material & $0.4 \%$ & $91.1 \%$ \\
\hline
\end{tabular}


Generally, $95 \%$ of the fabricated materials carried by truck is subject to competition by rail, and $75 \%$ of those carried by rail are subject to competition by truck. The composition of fabricated materials carried by rail and truck respectively are detailed in Tables 4.25 and 4.26 .

Table 4.23 FMI Link-by-Link Share of Interprovincial Railway Volume $1987(\%)$

\begin{tabular}{|c|c|c|c|c|c|c|}
\hline$O: \backslash D$ & Que. & Ont. & Man. & Sask. & Alta & B.C. \\
\hline Que. & & 10.4 & 0.3 & 0.1 & 0.3 & 0.4 \\
\hline Ont. & 7.1 & & 1.4 & 0.4 & 2.3 & 1.4 \\
\hline Man. & 0.8 & 2.8 & & 0.3 & 0.2 & 0.3 \\
\hline Sask. & 1.9 & 9.1 & 0.9 & & 0.7 & 18.9 \\
\hline Alta & 2.6 & 5.7 & 2.7 & 1.8 & & 14.1 \\
\hline B.C. & 4.5 & 6.3 & 0.6 & 0.3 & 1.4 & \\
\hline
\end{tabular}

Table 4.24 FMI Link-by-Link Share of Interprovincial Trucking Volume 1987 (\%)

\begin{tabular}{|c|c|c|c|c|c|c|}
\hline$O: \backslash D$ & Que. & Ont. & Man. & Sask. & Alta & B.C. \\
\hline Que. & & 25.0 & 0.4 & 0.2 & 0.4 & 0.2 \\
\hline Ont. & 19.6 & & 1.8 & 0.5 & 1.8 & 0.6 \\
\hline Man. & 0.2 & 2.8 & & 2.2 & 0.8 & 0.2 \\
\hline Sask. & - & 0.3 & 3.4 & & 2.7 & 0.3 \\
\hline Alta & 0.4 & 1.3 & 2.5 & 7.9 & & 11.7 \\
\hline B.C. & 0.2 & 0.5 & 0.7 & 1.3 & 10.3 & \\
\hline
\end{tabular}

While there has been a steady increase in the volume of fabricated materials freight carried by both the trucking and rail modes, the rate of increase for the rail industry has been greater than that for the trucking industry. In 1987, the total movement by trucking in the fabricated materials commodity section over all distances increased by about $8 \%$. The increase for the rail industry in this commodity section during the same period was about $14 \%$. Reforms in VWD regulations may change the above trend. 
Table 4.25 Railway Fabricated Materials Composition

\begin{tabular}{lrc}
\hline Commodity type & (\%) & $\begin{array}{c}\text { cum. } \\
(\%)\end{array}$ \\
\hline Muriate of potassium (potash) & $15.1 \%$ & $15.1 \%$ \\
Lumber & $12.6 \%$ & $27.7 \%$ \\
Woodpulp & $9.5 \%$ & $37.2 \%$ \\
Newsprint paper & $7.5 \%$ & $44.7 \%$ \\
Inorganic bases \& metal. oxides, hydroxydes \& peroxides, & & \\
$\quad$ n.e.s. & & \\
Refined and manufactured gases, fuel type (lpg) & $3.5 \%$ & $49.2 \%$ \\
Fertilizers and fertilizer materials, n.e.s. & $32.6 \%$ \\
Portland cement, standard & $3.2 \%$ & $55.7 \%$ \\
Sulphuric acid & $2.4 \%$ & $58.2 \%$ \\
Groundwood printing and specialty paper & $2.2 \%$ & $60.4 \%$ \\
Hydrocarbons and their derivatives & $2.1 \%$ & $62.5 \%$ \\
Diesel fuel & $2.1 \%$ & $64.6 \%$ \\
Plastic materials, not shaped and basic shapes and forms & $2.1 \%$ & $66.7 \%$ \\
Alcohols and their derivatives & $1.8 \%$ & $68.5 \%$ \\
Aluminum and aluminum alloy fabricated material, n.e.s. & $1.5 \%$ & $70.0 \%$ \\
Gasoline & $1.4 \%$ & $73.6 \%$ \\
Paperboard, n.e.s. & $1.3 \%$ & $74.2 \%$ \\
Sheet and strip steel & $1.2 \%$ & $75.5 \%$ \\
Ingots, blooms, billets and slabs, iron and steel & $1.2 \%$ & $76.6 \%$ \\
Wood building boards, n.e.s. & $1.1 \%$ & $77.8 \%$ \\
Metallic salts and peroxy salts of inorganic acids, n.e.s. & $1.1 \%$ & $78.9 \%$ \\
Coke, n.e.s. & $1.1 \%$ & $80.0 \%$ \\
Chemical elements & $1.1 \%$ & $81.0 \%$ \\
Fuel oil, n.e.s. & $1.1 \%$ & $82.1 \%$ \\
Other petroleum and coal products & $1.0 \%$ & $83.1 \%$ \\
Bars and rods, steel & $1.0 \%$ & $84.1 \%$ \\
\hline 1n.es $~$ & &
\end{tabular}

1 n.e.s. - not elsewhere specified

\subsubsection{4 $\diamond$ EPI: Commodity Movement and Composition}

The types of freight composing the majority of the end product commodity section for rail and truck are similar, showing the two modes of transport to be very competitive in this commodity classification, especially over medium and longer range distances.

As noted earlier, the cost per tonne to ship freight increases as distance in- 
Table 4.26 Trucking Fabricated Materials Composition

\begin{tabular}{lrc}
\hline Commodity type & $(\%)$ & $\begin{array}{c}\text { cum. } \\
(\%)\end{array}$ \\
\hline Lumber and sawn timber & $11.9 \%$ & $11.9 \%$ \\
Cement and concrete basic products & $10.8 \%$ & $22.7 \%$ \\
Fuel oil & $9.2 \%$ & $31.9 \%$ \\
Plate, sheet and strip, steel & $9.1 \%$ & $41.0 \%$ \\
Gasoline & $7.2 \%$ & $48.3 \%$ \\
Other non-metallic mineral basic products & $7.2 \%$ & $55.5 \%$ \\
Petroleum and coal products (exc. those in chemicals) & $7.2 \%$ & $62.6 \%$ \\
Chemical products, fertilizers and fertilizer materials & $4.4 \%$ & $67.0 \%$ \\
Paper for printing & $4.0 \%$ & $71.0 \%$ \\
Other chemical specialties, industrial & $2.5 \%$ & $73.6 \%$ \\
Other metal fabricated basic products & $2.2 \%$ & $75.8 \%$ \\
Wood pulp & $1.9 \%$ & $77.7 \%$ \\
Structural clay products and refractories & $1.7 \%$ & $79.4 \%$ \\
Pipes and tubes, iron and steel & $1.7 \%$ & $81.0 \%$ \\
Inorganic bases and metal. oxides, hydroxides and per- & & \\
$\quad$ oxides & $1.5 \%$ & $82.5 \%$ \\
Refined and manufactured gases, fuel type & $1.4 \%$ & $83.9 \%$ \\
Other wood fabricated materials & $1.4 \%$ & $85.3 \%$ \\
Metallic salts and peroxysalts of inorganic acids & $1.4 \%$ & $86.7 \%$ \\
Inorganic acids and oxygen comp. of nonmet. or metalloid $1.1 \%$ & $87.8 \%$ \\
\hline
\end{tabular}

creases, but the rate of this increase is higher for trucks than for rail. The shipping rates also differ substantially between eastbound and westbound movements. For each mode, westbound rates are higher than eastbound rates. Both of these characteristics are evident in Figure 4.30. This is attributed to the over supply of freight capacity for eastbound movements. To appreciate the scale of this inequity, in 1987 $62 \%$ of the total freight moved from east to west, leaving only $38 \%$ of the total to be carried from west to east.

This over supply can be explained in large part by two factors. The first of these is the concentration of manufacturing and population in just two eastern provinces, Ontario and Québec. A second factor has been a long-standing national government policy to mandate favourable rail transportation rates for raw materials flowing east, 
and for manufactured end products shipped west.

In terms of modal split, the EPI commodity section is similar to the FFB\&T commodity section, where rail has the majority share over medium and longer distances, and trucking dominates short distances and remains competitive over other ranges. This is can be clearly seen from Tables 4.27 and 4.28 , where, for example, the movement by rail between Québec and Ontario (short distance) constitutes about $24 \%$ and $44 \%$ of the rail and truck share of this commodity. For longer haul distances, for example British Columbia to Québec, rail carries $6.8 \%$ of its interprovincial EPI freight while trucking carries only $0.7 \%$ of its. Other examples of high rail share over longer distances can be seen in the links Ontario to Alberta and to British Columbia. It is interesting to notice that over these links that while rail has a higher share, the trucking industry still remains competitive.

The major types of end products moved by rail are listed in Table 4.29. Generally, automobiles and motor vehicle parts comprised the majority (76.6\%) of the total end products commodity moved by rail. Railway rolling stock refers primarily to parts and engines for railway service. Household and personal equipment includes domestic laundry equipment (washers, dryers, etc.), sewing machines, and luggage.

The major types of end products moved by trucking are listed in Table 4.30. This table shows the end products moved by truck to be characterized by numerous commodity types constituting small percentages of the total commodity tonnage moved. However, passenger automobiles, chassis, motor vehicle engines, and related automotive items (trucks, truck chassis, and tires) collectively account for over $32 \%$ of the end products moved by truck. 
Table 4.27 EPI Link-by-Link Share of Interprovincial Railway Volume 1987 (\%)

\begin{tabular}{|c|c|c|c|c|c|c|}
\hline$O: \backslash D:$ & Que. & Ont. & Man. & Sask. & Alta & B.C \\
\hline Que. & & 7.6 & 2.1 & 0.8 & 3.2 & 0.8 \\
\hline Ont. & 16.8 & & 7.7 & 5.2 & 16.9 & 11.8 \\
\hline Man. & 1.0 & 2.0 & & 0.3 & 0.7 & 0.8 \\
\hline Sask. & - & 0.1 & - & & - & - \\
\hline Alta & 1.0 & 1.8 & 0.5 & - & & 0.7 \\
\hline B.C. & 6.8 & 7.5 & 0.5 & 0.3 & 1.3 & \\
\hline
\end{tabular}

Table 4.28 EPI Link-by-Link Share of Interprovincial Trucking Volume $1987(\%)$

\begin{tabular}{|c|c|c|c|c|c|c|}
\hline$O: \backslash D:$ & Que. & Ont. & Man. & Sask. & Alta & B.C \\
\hline Que. & & 21.5 & 1.1 & 0.4 & 1.5 & 1.1 \\
\hline Ont. & 23.6 & & 3.7 & 1.3 & 4.7 & 3.8 \\
\hline Man. & 0.5 & 3.3 & & 2.6 & 2.4 & 0.4 \\
\hline Sask. & 0.1 & 0.5 & 0.6 & & 2.3 & 0.4 \\
\hline Alta & 0.6 & 1.8 & 1.4 & 3.5 & & 7.0 \\
\hline B.C. & 0.7 & 1.8 & 0.8 & 0.7 & 5.9 & \\
\hline
\end{tabular}


Table 4.29 Railway End Products Composition

\begin{tabular}{lcc}
\hline Commodity type & $\%$ & cum.\% \\
\hline Motor vehicle engines, accessories, & & \\
$\quad$ parts assemblies & 32.4 & 32.4 \\
Passenger automobiles and chassis & 29.2 & 61.6 \\
Road motor vehicles, n.e.s. & 16.0 & 76.6 \\
Toiletries, cleaning preparations & & \\
$\quad$ and household chemical specialties & 3.2 & 79.8 \\
Railway rolling stock & 2.6 & 82.4 \\
Household and personal equipment n.e.s. & 1.4 & 83.8 \\
\hline
\end{tabular}

* not elsewhere specified

Table 4.30 Trucking End Products Composition

\begin{tabular}{lll}
\hline Commodity type & $\%$ & cum.\% \\
\hline Passenger automobiles and chassis & 14.2 & 14.2 \\
Motor vehicle engines, accessories, & & \\
$\quad$ parts \& assemblies & 11.5 & 25.7 \\
Shipping and distribution containers & & \\
$\quad$ and closures & 11.1 & 36.8 \\
Paper end-products & 7.9 & 44.7 \\
Drilling, excavating, mining, oil and & & \\
$\quad$ gas machinery & 7.0 & 51.7 \\
Truck, truck chassis, and truck tractors & 3.5 & 55.2 \\
Pneumatic tires, new (tubeless or tube type) & 3.0 & 58.2 \\
Other machinery classified by function & 2.7 & 60.9 \\
Other special industrial machinery & 2.5 & 63.4 \\
Construction and maintenance equipment & 2.3 & 65.7 \\
Other materials handling equipment & 2.0 & 67.7 \\
Household furniture & 1.9 & 69.6 \\
Miscellaneous household and personal equipment & 1.7 & 71.3 \\
Floor coverings & 1.7 & 73.0 \\
Miscellaneous electric equipment \& appliances & 1.4 & 74.4 \\
Other printed matter & 1.2 & 75.6 \\
Cleaning and polishing preparations & 1.2 & 76.8 \\
Stationary and office paper supplies1.0 & 77.8 & \\
Toilet preparations and cosmetics & 1.0 & 78.8 \\
\hline
\end{tabular}




\section{MODEL DEVELOPMENT \& CALIBRATIONS}

Commodity movement traffic is proportional to a product of the supply and demand variables at origin and destination, and the service characteristics of the transport system between them. In general, the model structure is as follows:

$$
V_{i j m}=f\left(S_{i}, D_{j}, X_{1}, X_{2}, \ldots, X_{m}, \ldots, X_{n}\right)
$$

$V_{i j m}=$ volume between regions $i$ and $j$ by mode $m$

$S_{i}=$ supply available at region $i$, as a function of socio-economic conditions at origin

$D_{j}=$ demand needed at region $j$, as a function of socio-economic conditions at destination

$X_{m}=$ transport service characteristics of mode $m$

$n=$ number of modes

The Statistical Analysis System (SAS) was utilized to run many models (utilizing different variable combinations) using 1983 through 1987 data for each of the four principal commodity sections (Food, feed, beverages and tobacco (FFB\&T), Crude materials, inedible (CMI), Fabricated materials, inedible (FMI), and End products, inedible(EPI) ). The models utilized twelve different combinations of the travel time 
by rail, cost by truck, and cost by rail variables for each of six commodity data sets (1983, 1984, 1985, 1986, 1987 and combined 1983 through 1987). These 72 different formulations were applied to each of the four commodity sections, resulting in 288 model-data set combinations. From the 288 model-data set combinations tested, many were selected for closer examination and evaluated according to their statistical measures and reliability. The selection process of the models' variables and their validation is detailed below.

\section{$5.1 \diamond$ The Selected Models}

For each of the elements in the model structure expressed above, variables were selected for inclusion in the model on the basis of their contribution to the strength and significance of the resulting equations, and on the basis of their utility in a mode split capacity. This resulted in the following model form for all four commodity sections:

$$
\begin{aligned}
& V_{i j k}= \alpha_{0} \cdot\left(P O P_{i} \times I N D_{i}\right)^{\alpha_{1}} \cdot\left(I N C_{i} \times M K_{i}\right)^{\alpha_{2}} \cdot T T_{k}^{\alpha_{3}} \cdot C_{k}^{\alpha_{4}} \\
& \cdot\left(P O P_{j} \times I N D_{j}\right)^{\alpha_{5}} \cdot\left(I N C_{j} \times M K_{j}\right)^{\alpha_{6}} \cdot T T_{\tau}^{\alpha_{7}} \cdot C_{\tau}^{\alpha_{\delta}} \\
& V_{i j k}=\text { volume by truck }(\times 1000 \mathrm{t})
\end{aligned}
$$

$S_{i}$ : Supply available at origin region $i$

$P O P_{i} \times I N D_{i}=$ product of population (in thousands) and industrial index at origin

$I N C_{i} \times M K_{i}=$ product of per capita income and market index at origin

$D_{j}$ : Demand needed at destination region $j$

$P O P_{j} \times I N D_{j}=$ product of population (in thousands) and industrial index at destination

$I N C_{j} \times M K_{j}=$ product of per capita income and market index at destination $X_{k}$ : Transportation service characteristics for trucking

$T T_{k}=$ travel time by truck (days)

$C_{k}=$ cost by truck $(\$ /$ tonne $)$

$X_{r}$ : Transportation service characteristics for rail

$T T_{T}=$ travel time by rail (days)

$C_{\tau}=$ cost by rail estimated by function ( $\$ /$ tonne) 
$\alpha_{0}, \alpha_{1}, \ldots, \alpha_{8}=$ coefficients derived by regression analysis.

As explained in Chapter 4 , because of inconsistencies and discrepancies in the raw rail revenue-per-tonne data, it was necessary to develop a function to explain $C_{r}$ in relation to distance. For the three commodity sections FFB\&T, FMI and EPI, a regression analysis was conducted using data for years 1983 through 1987 inclusive, and resulted in equation $[5.3]$.

$$
C_{\tau}=D_{o d}^{\beta}
$$

$C_{r}=$ estimated cost by rail ( $\$ /$ tonne)

$D_{o d}=$ Distance between the principal cities of origin and destination $(\mathrm{km})$

$\beta=$ coefficient derived by regression analysis.

For the commodity section CMI the $C_{r}$ variable expressed equation [4] was used.

$$
C_{r} \equiv \begin{cases}C_{r i j} & \text { where } i \rightarrow j \text { is eastbound } \\ C_{r j i} & \text { where } i \rightarrow j \text { is westbound }\end{cases}
$$

The objective of developing a mathematical model is the simplification of reality through the quantitative examination and analysis of those variables which can be adequately measured. Only a limited number of independent or predictor variables can be included in a regression model for any given situation. The major considerations for choosing a set of independent variables for analysis purposes are: (1) the importance or impact of the independent variable in the determining the dependent variable in the process being modelled; (2) the extent to which the variable contributes to minimizing the difference between the observed and calculated values; and (3) the statistical significance of each independent variable. In consideration of these three conditions, the eight independent variables listed above were selected for inclusion in the model. 
Two cross-variables were used to represent supply at origin $\left(S_{i}\right)$, the product of population and industrial index at origin, and the product of per capita income and market index at origin. Demand at destination $\left(D_{j}\right)$ was similarly represented. Transport service characteristics $\left(X_{m}\right)$ are represented in the model by the travel time and user cost for each of the two modes.

The use of cross-variables was introduced as a result of the high correlation between the pairs of variables that were combined. When these variables were individually included in the model, most of them were not significant. For example, when included individually, EPI Model, population at destination and industrial index at destination had significances of $62 \%$ and $73 \%$ respectively. When these single variables were combined, the significance of the resulting cross-variable rose to $99.99 \%$. This refinement also yielded $t$-value improvements for other variables. The multiplying together of these pairs resolves the difficulty posed by their multicollinearity. The terms introduced are similar to the square of one component variable and the resulting coefficients are correspondingly doubled. This simplification however, masks the contributions to the models made by the differences between each member component of each of the cross-variables used. Since subsequent VWD impact analysis does not depend directly on the values of these coefficients, there is no denigration of model utility and the improved t-values for other model components suggests their inclusion improves the models.

\section{$5.2 \odot$ Validity of Developed Models}

\subsection{1 $\odot$ Pragmatic Validation}

The models were tested against pragmatic and statistical conditions. The pragmatic condition was satisfied by the negative elasticities of the truck service attributes (cost and travel time) and the positive co-elasticities of the model. The negative elasticities of the truck service attributes indicate that any reduction in the level of service for trucking will result in a decrease in its market share. Conversely, the positive sign 
for the cost and time coefficients by rail indicates that a reduction in the railway's level of service will increase the market share of trucking while reducing its own market share.

\section{$5.2 .2 \diamond$ Statistical Validation}

Statistical significance was evaluated by a number of tests. The constancy of variance and the normality (normal distribution) of the data were examined using the plots of the residuals. The F-test for instance, was used to assess the validity of each model as a whole. Maximum $R^{2}$ Improvement, Mallow's $C_{p}$ Statistics and Mean Squared Error procedures were performed for each of the four models and showed all eight variables to be highly significant. These procedures are depicted for models of each of the four commodity sections, in a series of three curves each.

The first figure (Figures 5.1, 5.4, 5.7, and 5.10 for FFB\&T, CMI, FMI, and EPI respectively) illustrates maximum $R^{2}$ improvement which measures the percentage of the dependent variable explained by the independent variables. It can be seen that great improvement in $R^{2}$ value occurs up to the inclusion of four variables. Beyond that, less improvement in $R^{2}$ occurs. However, the inclusion of the latter variables, namely: the transportation service characteristics (travel time and cost by rail and truck), are very significant in determining modal split.

The second figure (Figures 5.2, 5.5, 5.8, and 5.11 for FFB\&T, CMI, FMI, and EPI respectively) illustrates mean squared error which measures the degree of variance or deviation among the model parameters or variables in accurately predicting the dependent variable. The curve shows that error or standard deviation is reduced as more variables are added to the model. Once again, the first four variables reduce standard deviation considerably, but the addition of the last four which are important in determining modal split, also reduces error.

The third figure (Figures 5.3, 5.6, 5.9, and 5.12 for FFB\&T, CMI, FMI, and EPI respectively) depicts Mallow's $C_{P}$ Statistic which is a simple criterion of goodness 


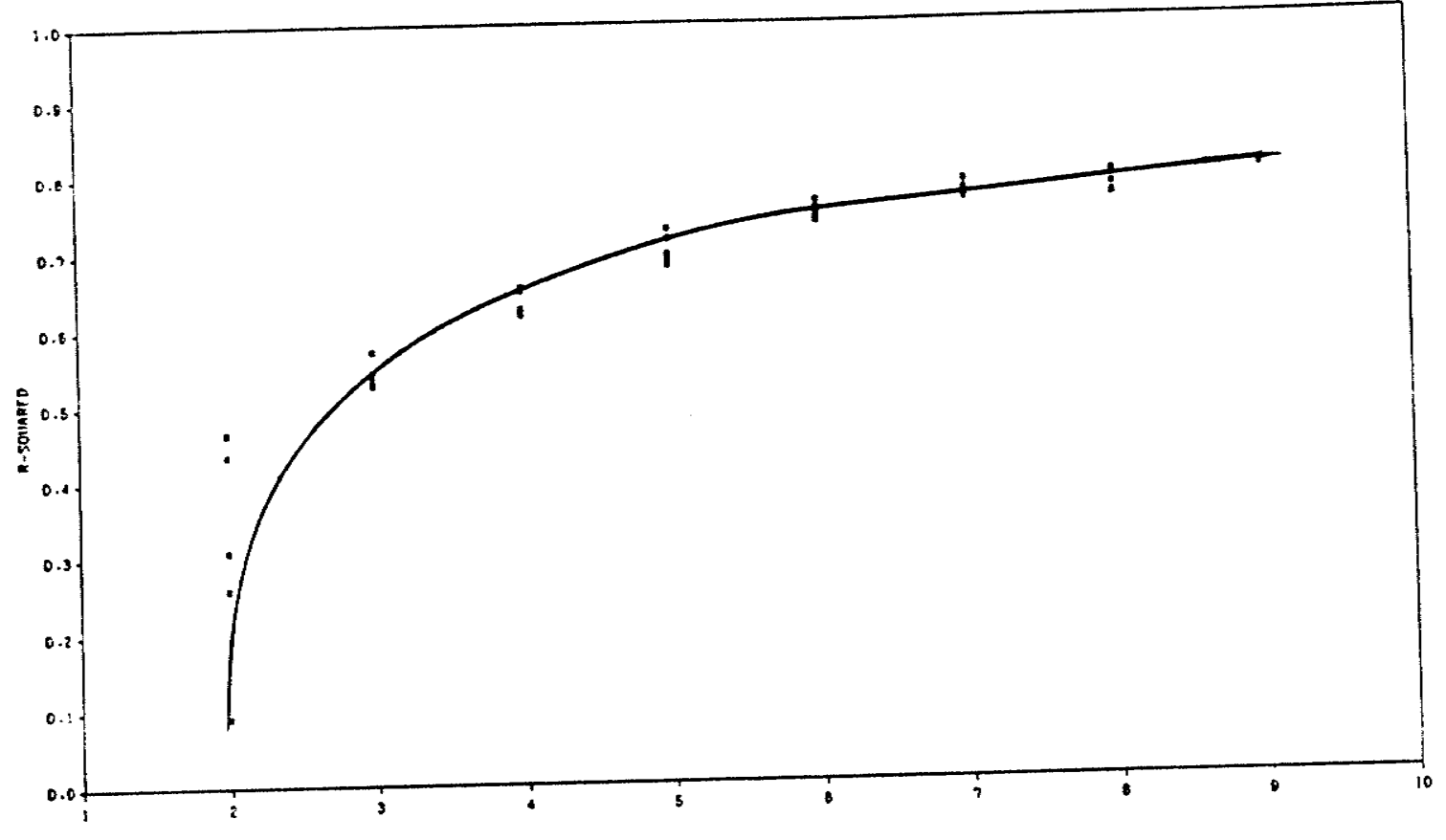

Number of Parameters in the Model

Figure 5.1 FFB\& T: Maximum $R^{2}$ Improvement as a function of the number of parameters in the nodel.

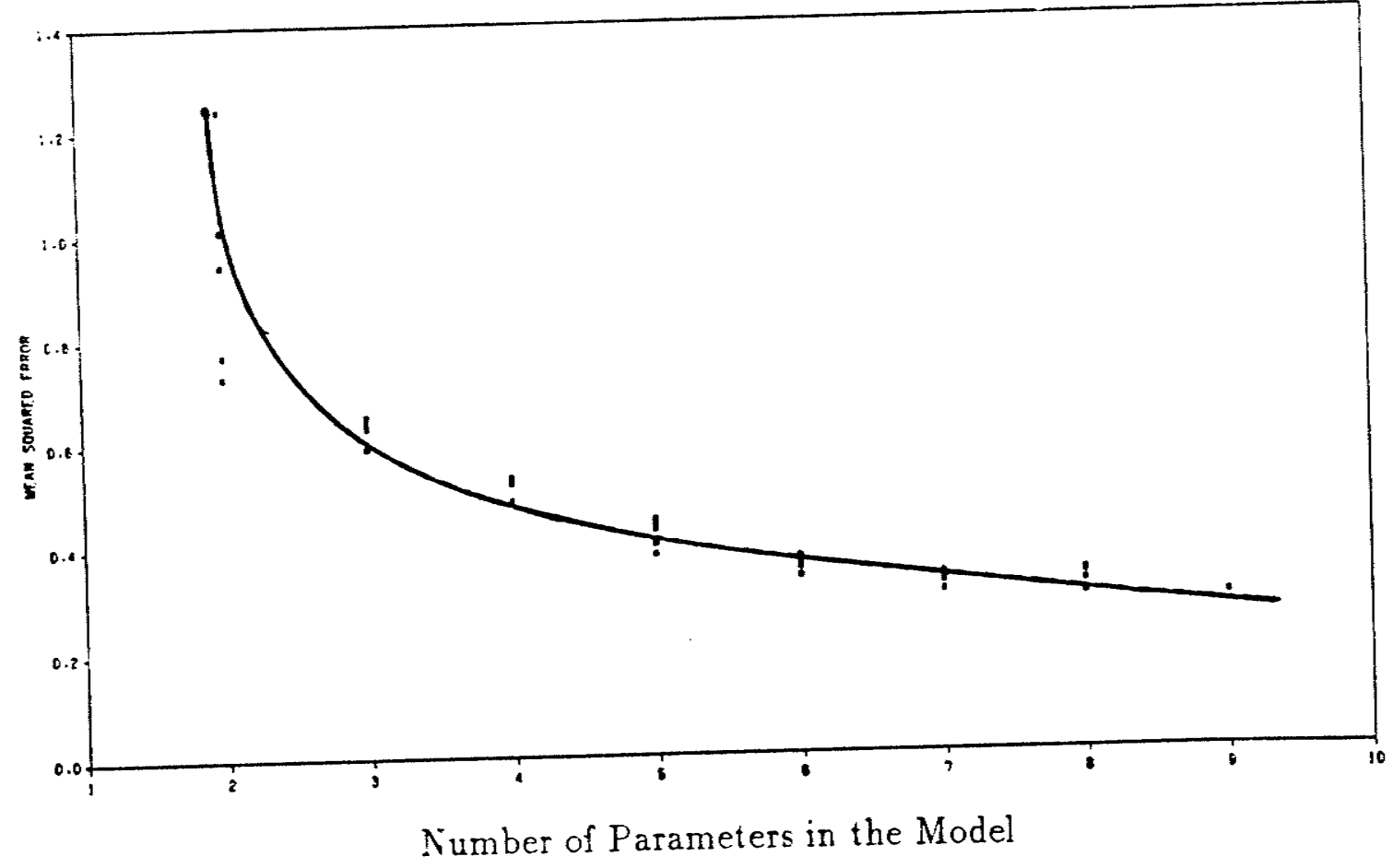

Figure 5.2 FFB\&T: Mean Square Error Improvement as a function of the number of parameters in the model. 


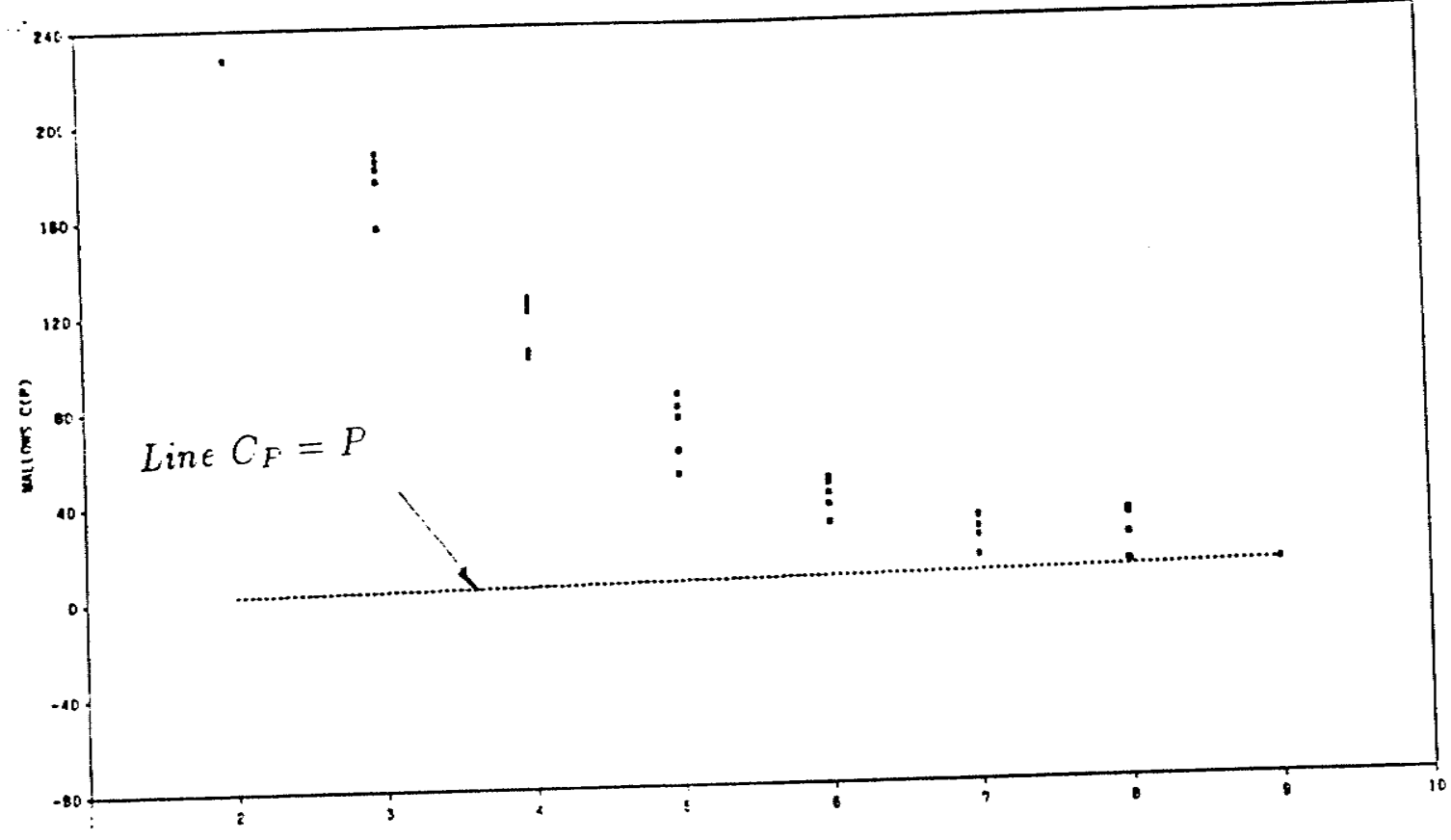

Number of Parameters in the Model

Figure 5.3 FFB\& T: Mallow's $C_{P}$ Statistic Improvement as a function of the number of parameters in the model.

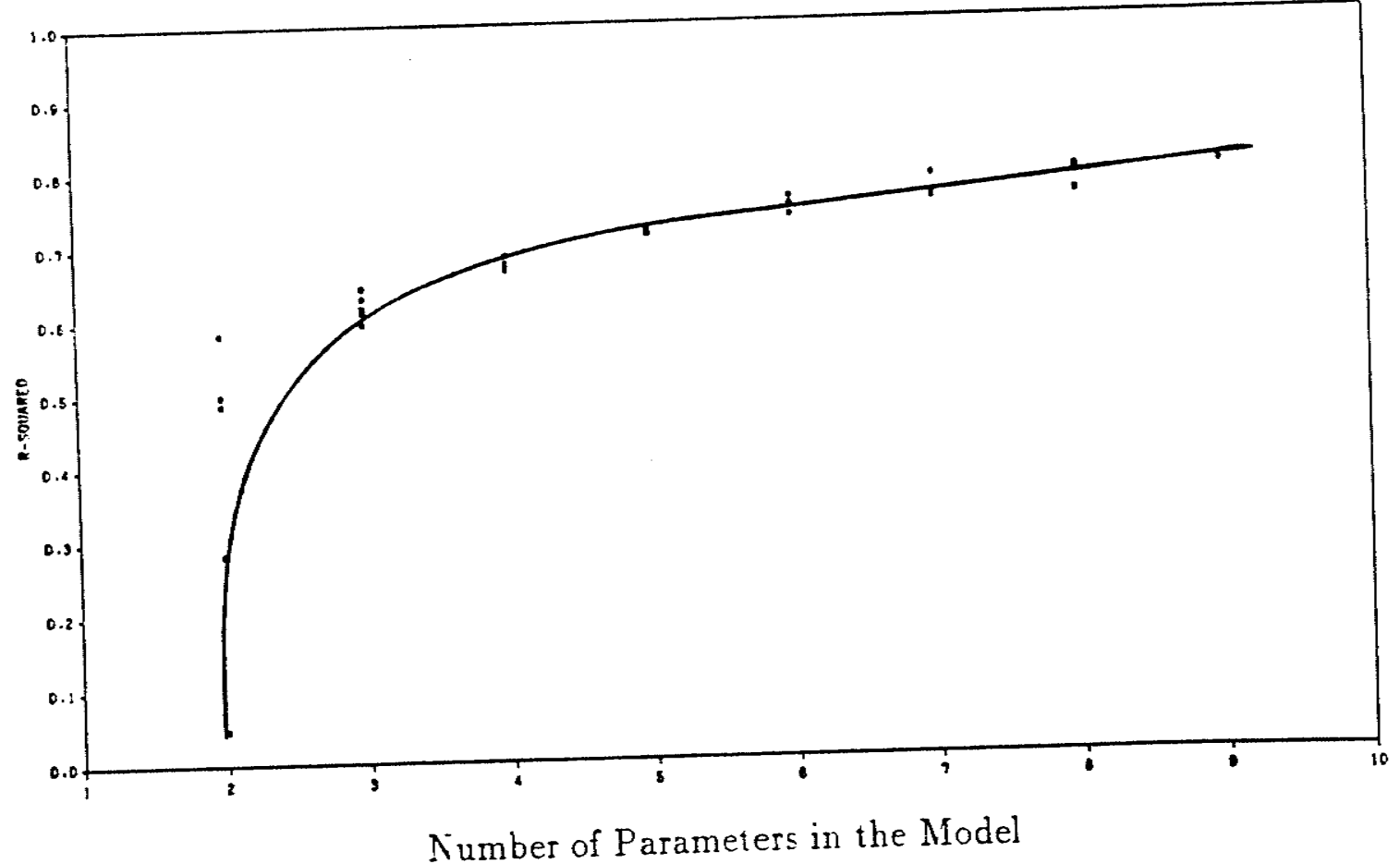

Figure 5.4 CMI: Maximum $R^{2}$ Improvement as a function of the number of parameters in the model. 


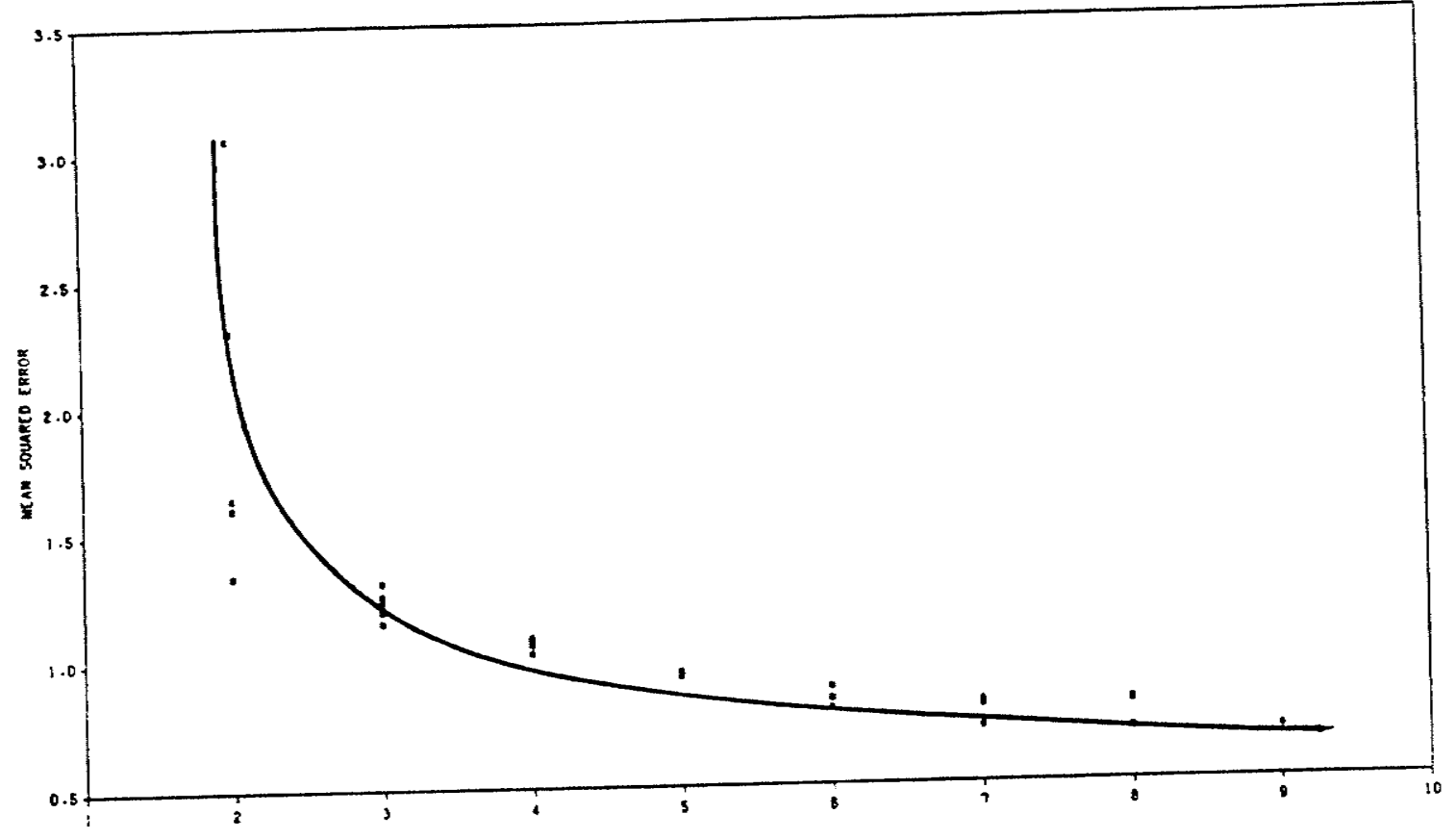

Number of Parameters in the Model

Figure 5.5 CMI: Mean Square Error Improvement as a function of the number of parameters in the model.

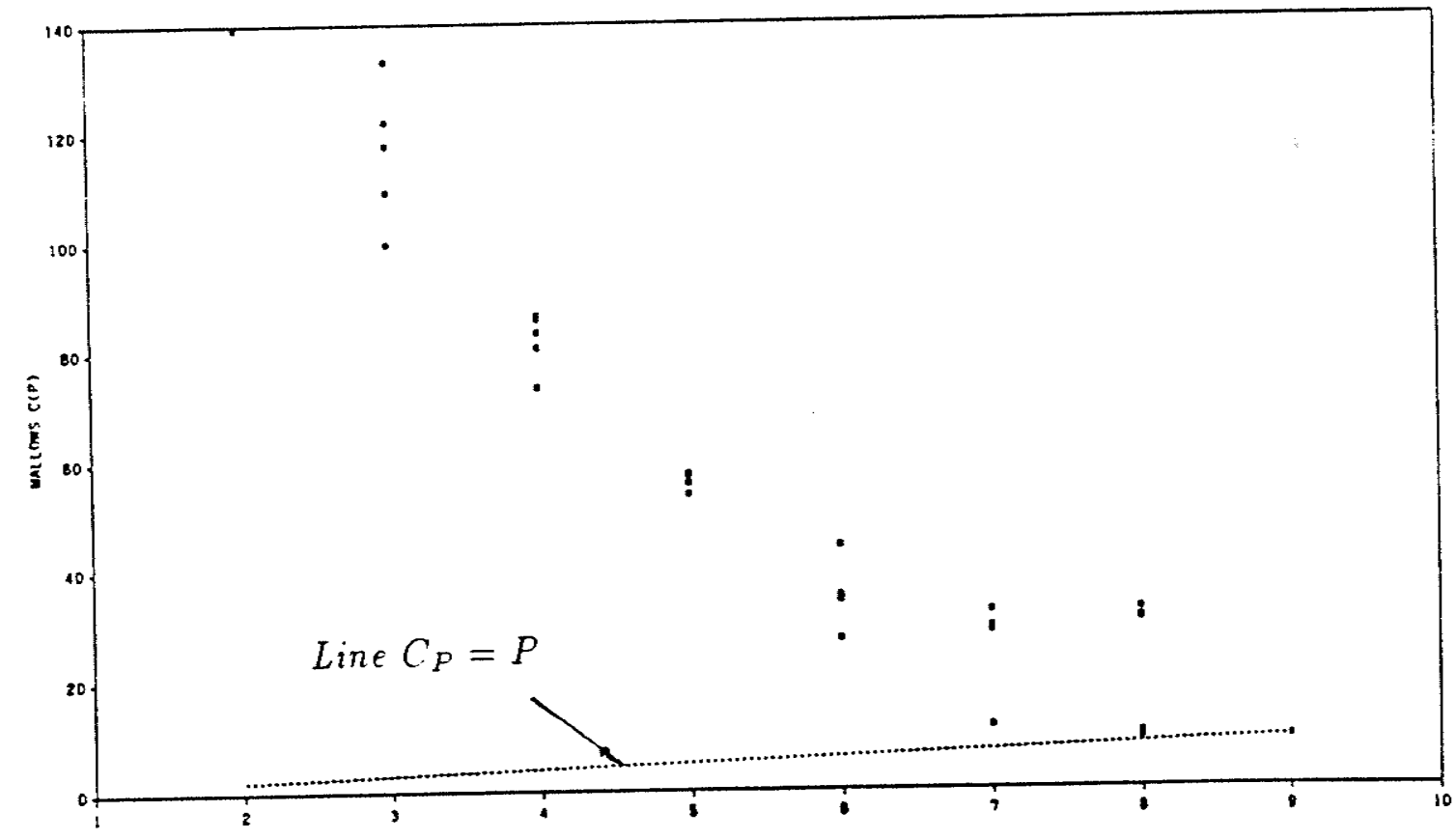

Number of Parameters in the Model

Figure 5.6 CMI: Mallow's $C_{P}$ Statistic Improvement as a function of the number of parameters in the model. 


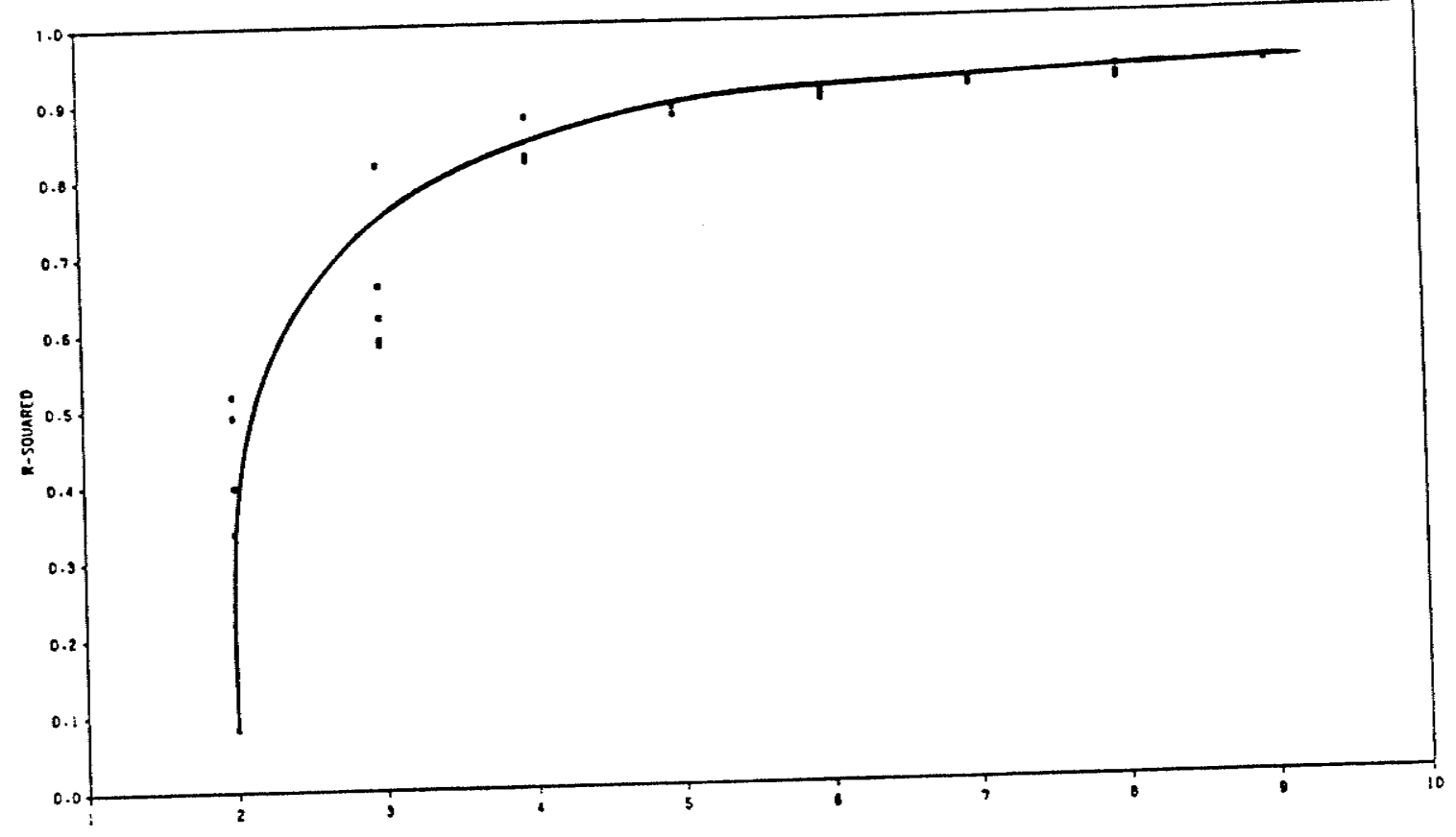

Number of Parameters in the Model

Figure 5.7 FMI: Maximum $R^{2}$ Improvement

as a function of the number of parameters in the model.

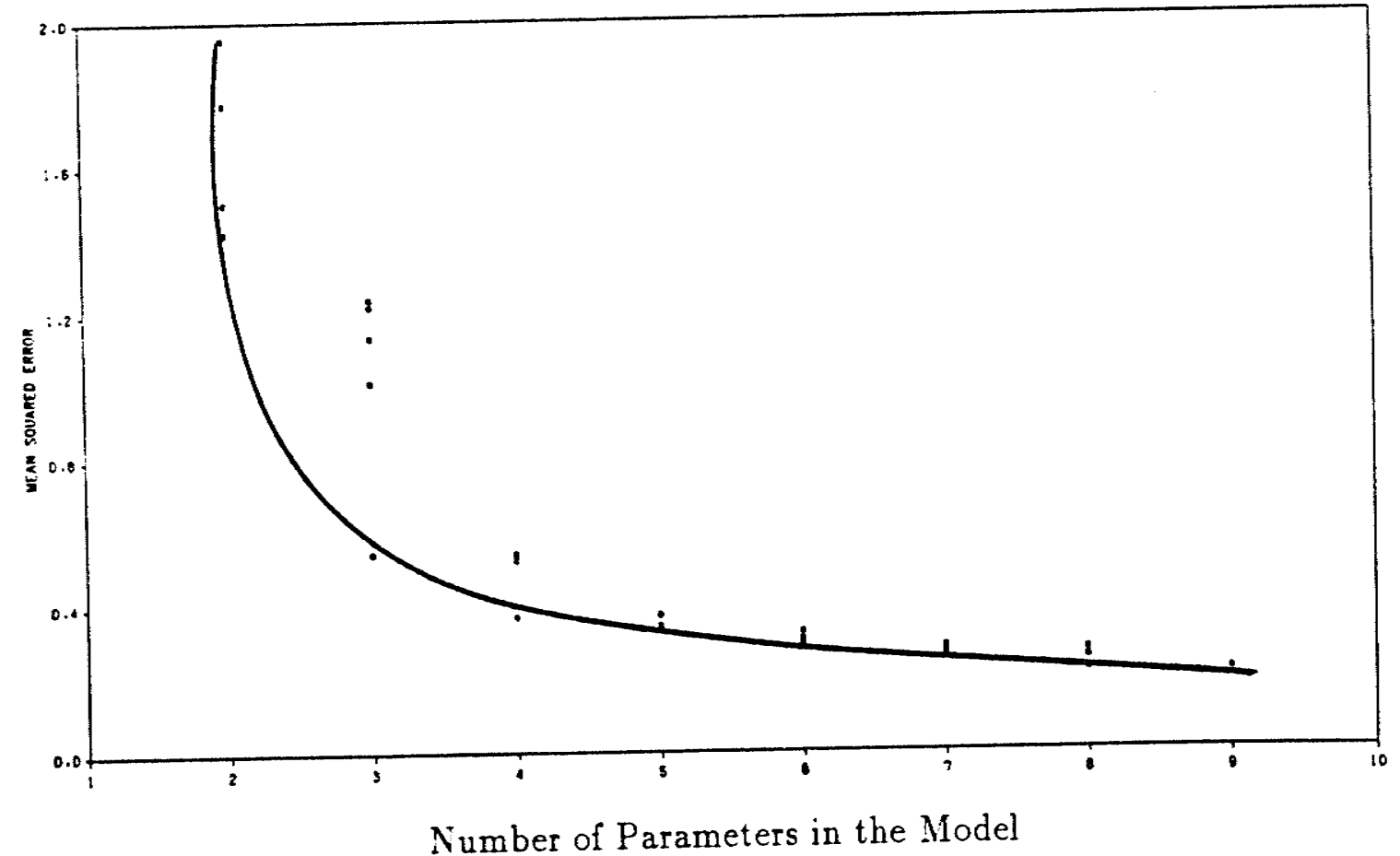

Figure 5.8 FMI: Mean Square Error Improvement

as a function of the number of parameters in the model. 


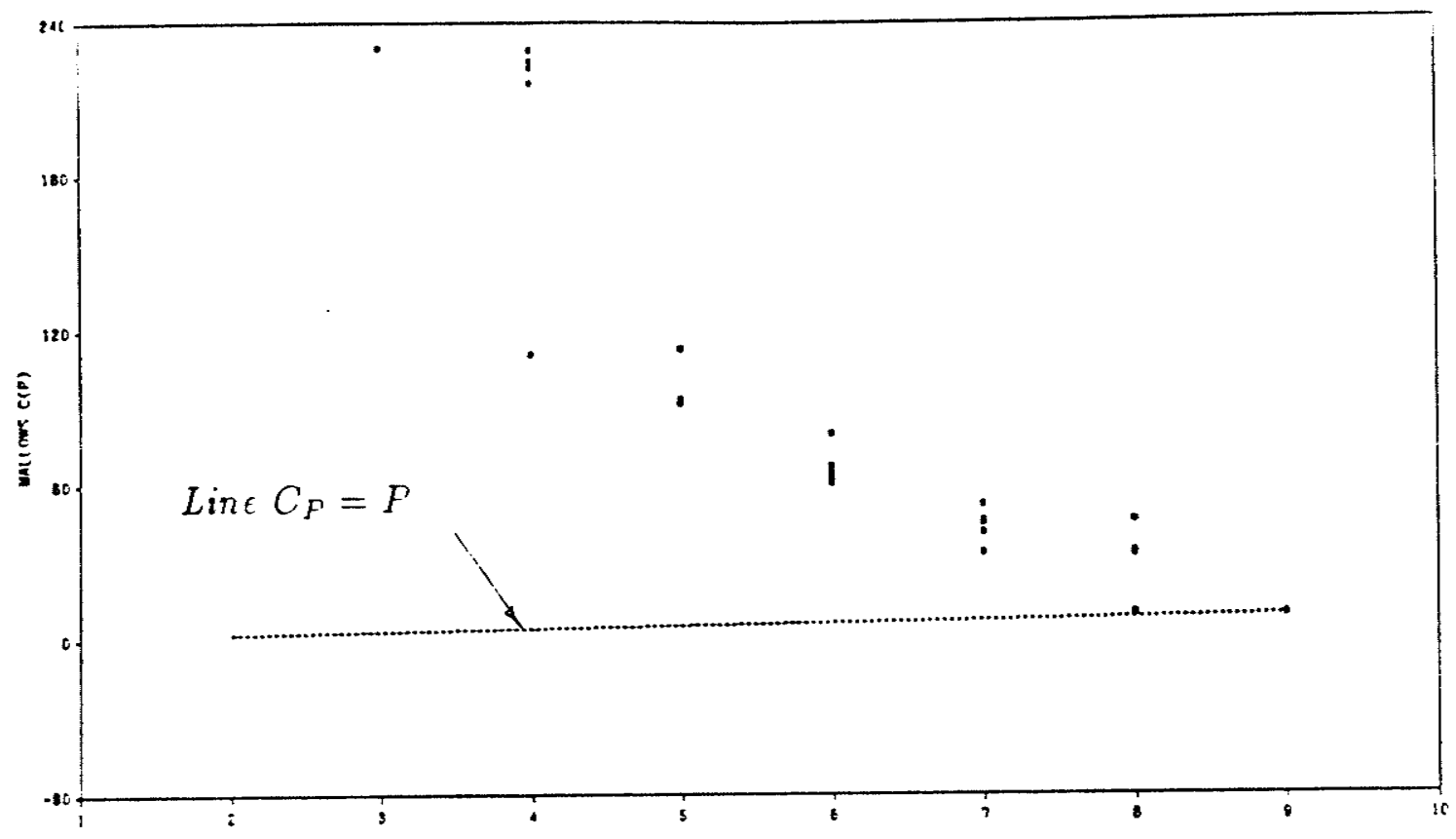

Number of Parameters in the Mode!

Figure 5.9 FMI: Mallow's $C_{P}$ Statistic Improvement as a function of the number of parameters in the model.

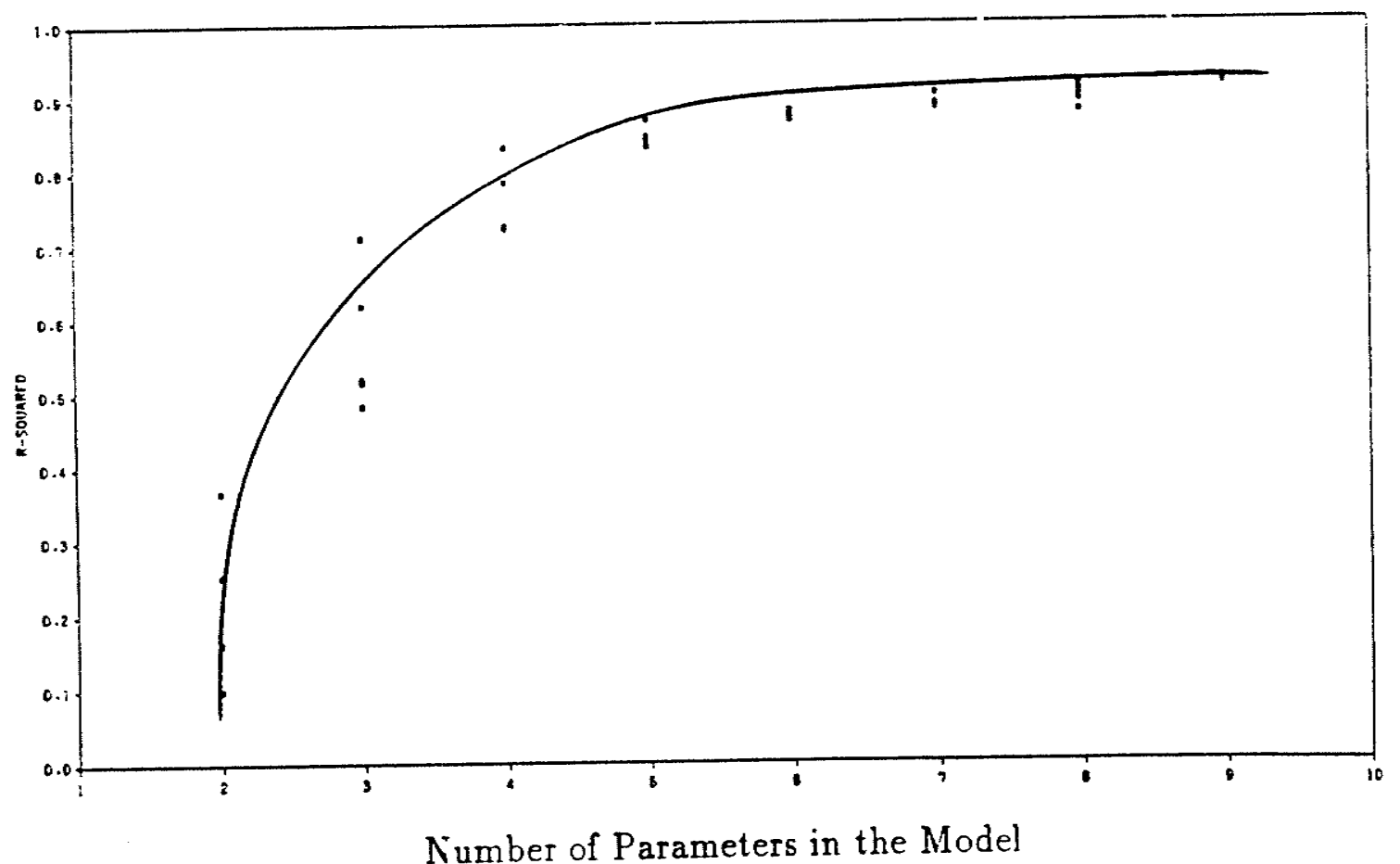

Figure 5.10 EPI: Maximum $R^{2}$ Improvement as a function of the number of parameters in the model. 


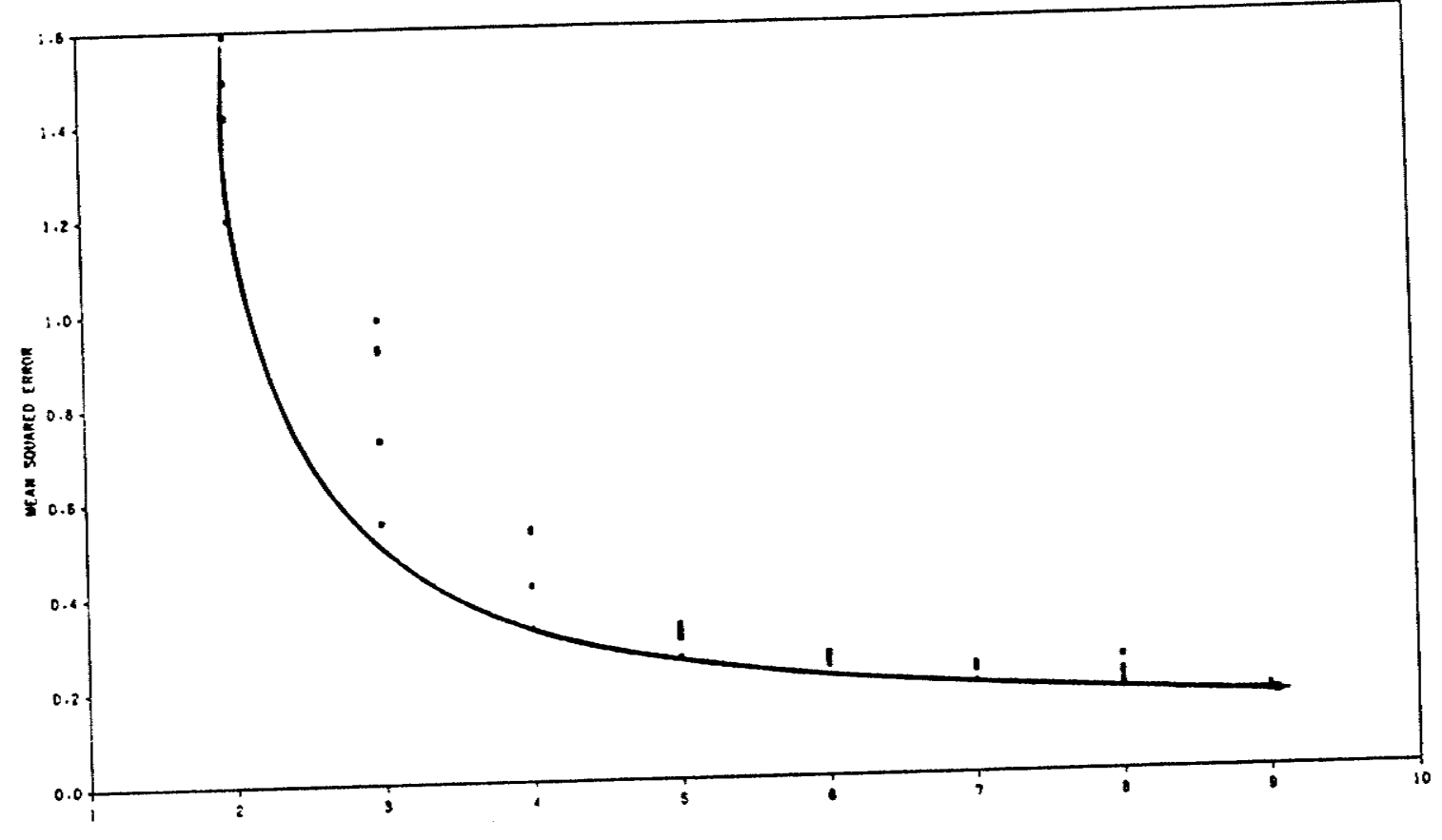

Number of Parameters in the Model

Figure 5.11 EPI: Mean Square Error Improvement

as a function of the number of parameters in the model.

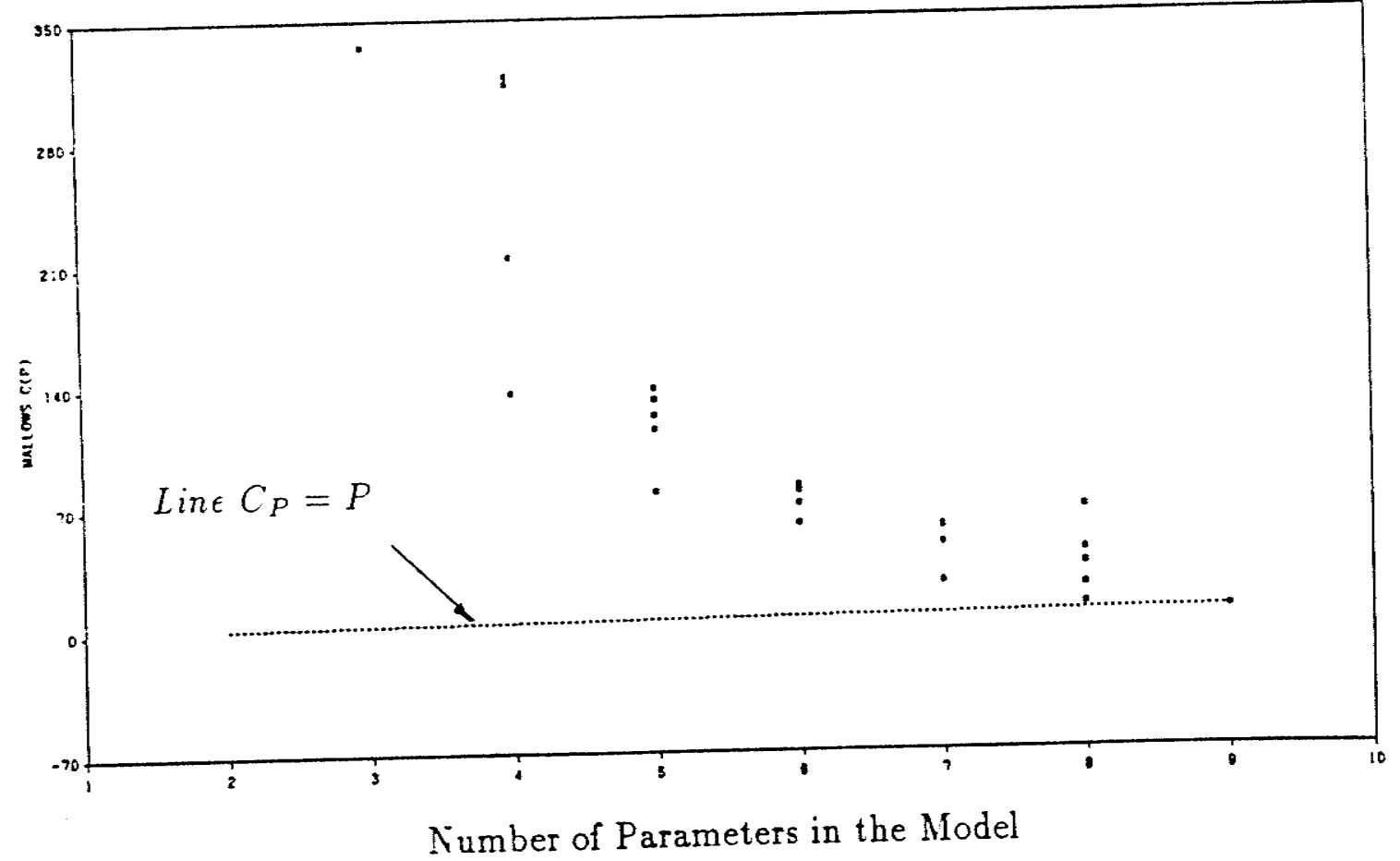

Figure 5.12 EPI: Mallow's $C_{P}$ Statistic Improvement as a function of the number of parameters in the model. 
of fit. When a number of alternative models varying in the number and selection of variables are being considered, Mallow's $C_{P}$ Statistic is useful in detecting the unbiased model. The $C_{P}$ values for all possible regression models are plotted against the number of parameters $(P)$, and those models with little bias will tend to fall near the line $C_{P}=P$. Models with substantial bias will fall considerably above the line.

In using the $C_{P}$ criterion, one seeks to identify subsets of variables for which the $C_{P}$ value is small, and the $C_{P}$ value is near $P$. The model with the sets of variables with small $C_{P}$ values have small mean square error and, when the $C_{P}$ value is near $P$, the bias of the regression model is small. From the third figures, it can be seen that, once again, the first four variables reduce considerably the $C_{P}$ value, while the addition of the last four variables results in the $C_{P}$ value of the model closely approaching the line $C_{P}=P$.

\section{$5.2 .3 \diamond$ Analysis of Variance}

Tables 5.1, 5.2, 5.3, and 5.4 show the analysis of variance for the selected model of the FFB\&T, CMI, FMI, and EPI commodity sections respectively. To validate this selected model, as previously mentioned, a number of statistical techniques were used. The ratio of Mean Sum Square of Regression (explained variation) to the Mean Sum Square of Residuals (unexplained variation) or the F-value was found to be 69.578 for the FFB\&T model, 67.949 for the CMI model, 239.137 for the FMI model, and 190.014 for the EPI model, all with a probability (P-value) of 0.0001 indicating a level of significance of $99.99 \%$. This P-value suggests very strongly that the models are valid and adequately fit the data.

The Mean Square Error of 0.2892 for the FFB\&T model, 0.6936 for CMI, 0.2125 for FMI, and 0.0930 for EPI all indicate deviation between the observed and calculated values to be very small and suggests that the models are reliable in predicting effects of new VWD policy implementation on freight transportation in Canada. Furthermore, the $R^{2}$ value for the FFB\&T model is 0.7979 meaning the parameters of the model 
are reliable in predicting the effects of this policy changes up to $79.79 \%$ of the FFB\&T freight movement between provinces in Canada. Similarly, the $R^{2}$ value for the CMI, FMI and EPI models are $0.7940,0.9314$ and 0.9151 respectively. These values attest that up to $79.40 \%$ of CMI, up to $93.14 \%$ of FMI and up to $91.51 \%$ of EPI freight movement between provinces in Canada is explained by the respective models.

Table 5.1 FFB\&T: Analysis of Variance

\begin{tabular}{|c|c|c|c|c|c|}
\hline Source & $\mathrm{DF}$ & $\begin{array}{l}\text { Sum of } \\
\text { Squares }\end{array}$ & $\begin{array}{l}\text { Mean } \\
\text { Square }\end{array}$ & $F$ value & Prob $>F$ \\
\hline Model & 8 & 161.0039 & 20.12554 & 69.578 & 0.0001 \\
\hline Error & 141 & 40.7842 & 0.2893 & & \\
\hline C Total & 149 & 201.7881 & & & \\
\hline R-Square & & 0.7979 & & & \\
\hline
\end{tabular}

Table 5.2 CMI: Analysis of Variance

\begin{tabular}{|c|c|c|c|c|c|}
\hline Source & $\mathrm{DF}$ & $\begin{array}{l}\text { Sum of } \\
\text { Squares }\end{array}$ & $\begin{array}{l}\text { Mean } \\
\text { Square }\end{array}$ & $\mathrm{F}$ Value & Prob $>F$ \\
\hline Model & 8 & 377.0388 & 47.1298 & 67.9490 & 0.0001 \\
\hline Error & 141 & 97.7986 & 0.6936 & & \\
\hline C Total & 149 & 474.8374 & & & \\
\hline R-Square & & 0.7940 & & & \\
\hline
\end{tabular}

Table 5.3 FMI: Analysis of Variance

\begin{tabular}{|c|c|c|c|c|c|}
\hline Source & $\mathrm{DF}$ & $\begin{array}{l}\text { Sum of } \\
\text { Squares }\end{array}$ & $\begin{array}{l}\text { Mean } \\
\text { Square }\end{array}$ & F Value & Prob $>F$ \\
\hline Model & 8 & 406.5548 & 50.8193 & 239.137 & 0.0001 \\
\hline Error & 141 & 29.9641 & 0.2125 & & \\
\hline C Total & 149 & 436.5139 & & & \\
\hline R-Square & & 0.9314 & & & \\
\hline
\end{tabular}


$-92-$

Table 5.4 EPI: Analysis of Variance

\begin{tabular}{|c|c|c|c|c|c|}
\hline Source & $\mathrm{DF}$ & $\begin{array}{l}\text { Sum of } \\
\text { Squares }\end{array}$ & $\begin{array}{l}\text { Means } \\
\text { Square }\end{array}$ & F Value & Prob $>F$ \\
\hline Model & 8 & 256.6056 & 32.0756 & 190.014 & 0.0001 \\
\hline Error & 141 & 23.8017 & 0.1688 & & \\
\hline C Total & 149 & 280.4062 & & & \\
\hline R-Square & & 0.9151 & & & \\
\hline
\end{tabular}

\section{$5.2 .4 \diamond \quad$ Parameter Estimates}

After establishing the veracity of the overall model, each variable was tested individually to check its validity. The ratio of each parameter estimate to its standard error was used in order to calculate the $\mathrm{T}$ value based on the null hypothesis $\left(H_{0}\right)$. The results as shown in Tables 5.5 through 5.8 show a satisfactory probability values ranging from 0.1725 to 0.0001 . For FFB\&T (Table 5.5) seven of the variables have $99.9 \%$ levels of confidence, while travel time and cost by rail have $92.0 \%$ levels of confidence.

Table 5.5 FFB\&T: Parameter Estimates

\begin{tabular}{rrrrr}
\hline & Parameter & Standard & $T$ for $H_{0}:$ & \\
Variable & Estimate & Error & Parameter $=0$ & Prob $>|T|$ \\
\hline Intercept $\left(\ln \left(\alpha_{0}\right)\right)$ & -60.4383 & 8.3913 & -7.2020 & 0.0001 \\
$P O P_{O} \times I N D_{O}$ & 0.6373 & 0.0850 & 7.4900 & 0.0001 \\
$I N C_{O} \times M K_{O}$ & 2.1083 & 0.3602 & 5.8530 & 0.0001 \\
$T T_{T}$ & -3.2065 & 0.6497 & -4.9360 & 0.0001 \\
$C_{T}$ & -0.5584 & 0.1175 & -4.7520 & 0.0001 \\
$P O P_{D} \times I N D_{D}$ & 0.6429 & 0.0878 & 7.3060 & 0.0001 \\
$I N C_{D} \times M K_{D}$ & 1.3253 & 0.3497 & 3.7900 & 0.0002 \\
$T T_{R}$ & 0.8382 & 0.4746 & 1.7660 & 0.0795 \\
$C_{R}$ & 1.3918 & 0.7930 & 1.7550 & 0.0814 \\
\hline$D_{\text {od }}$ & 0.5246 & 0.0045 & 115.32 & 0.0001 \\
\hline & & & &
\end{tabular}

Other descriptive measures of the degree of association between dependent and independent variables were also computed. The Pearson Product-Moment Correlation 
$-93-$

Table 5.6 CMI: Parameter Estimates

\begin{tabular}{|c|c|c|c|c|}
\hline Variable & $\begin{array}{r}\text { Parameter } \\
\text { Estimate } \\
\end{array}$ & $\begin{array}{r}\text { Standard } \\
\text { Error } \\
\end{array}$ & $\begin{array}{r}T \text { for } H_{0}: \\
\text { Parameter }=0\end{array}$ & Prob $>|T|$ \\
\hline Intercept $\left(\ln \left(\alpha_{0}\right)\right)$ & -83.2348 & 11.0393 & -7.5400 & 0.0001 \\
\hline$P O P_{O} \times I N D_{O}$ & 0.4429 & 0.0909 & 4.8680 & 0.0001 \\
\hline$I N C_{O} \times M K_{O}$ & 2.7035 & 0.5379 & 5.0260 & 0.0001 \\
\hline$T T_{T}$ & -3.6581 & 0.6076 & -6.0200 & 0.0001 \\
\hline$C E_{T}$ & -0.5590 & 0.1155 & -4.8400 & 0.0001 \\
\hline$P O P_{D} \times I N D_{D}$ & 0.6818 & 0.0909 & 7.4950 & 0.0001 \\
\hline$I N C_{D} \times M K_{D}$ & 2.7023 & 0.5379 & 5.0240 & 0.0001 \\
\hline$T T_{R}$ & 1.4064 & 1.0257 & 1.3710 & 0.1725 \\
\hline$C E_{R}$ & 0.2960 & 0.1751 & 1.6900 & 0.0932 \\
\hline
\end{tabular}

Table 5.7 FMI: Parameter Estimates

\begin{tabular}{|c|c|c|c|c|}
\hline Variable & $\begin{array}{r}\text { Parameter } \\
\text { Estimate } \\
\end{array}$ & $\begin{array}{r}\text { Standard } \\
\text { Error } \\
\end{array}$ & $\begin{array}{r}T \text { for } H_{0}: \\
\text { Parameter }=0\end{array}$ & Prob $>|T|$ \\
\hline Intercept $\left(\ln \left(\alpha_{0}\right)\right)$ & -80.8082 & 7.465 & -10.8240 & 0.0001 \\
\hline$P O P_{O} \times I N D_{O}$ & 1.1270 & 0.0728 & 15.4460 & 0.0001 \\
\hline$I N C_{O} \times M K_{O}$ & 1.6412 & 0.3186 & 5.1520 & 0.0001 \\
\hline$T T_{T}$ & -3.5128 & 0.5647 & -6.2210 & 0.0001 \\
\hline$C_{T}$ & -1.5068 & 0.1234 & -12.2110 & 0.0001 \\
\hline$P O P_{D} \times I N D_{D}$ & 0.3912 & 0.0774 & 5.0520 & 0.0001 \\
\hline$I N C_{D} \times M K_{D}$ & 3.3253 & 0.2968 & 11.2010 & 0.0001 \\
\hline$T T_{R}$ & 2.2111 & 0.4388 & 5.0390 & 0.0001 \\
\hline$C_{R}$ & 1.1184 & 0.6788 & 1.6480 & 0.1017 \\
\hline$D_{o d}$ & 0.5316 & 0.0050 & 106.38 & 0.0001 \\
\hline
\end{tabular}

Coefficient of $R=0.8932$ for the FFB\&T model shows a strong correlation between the independent and dependent variables tested. The null and alternate hypotheses were tested for reliability of $R$ at 0.01 level of significance, a two tailed test was applied and the latter hypothesis was accepted. For the three other models, the Product-Moment Correlation Coefficients are $R=0.8910$ (CMI), $R=0.9314$ (FMI) and $R=0.9566$ (EPI). As with FFB\&T, the two-tailed test applied to validate either the null or alternative hypotheses satisfied the latter's acceptance. 
Table 5.8 EPI: Parameter Estimates

\begin{tabular}{rrrrr}
\hline & Parameter & Standard & $T$ for $H_{0}:$ & \\
Variable & Estimate & Error & Parameter=0 & Prob $>|T|$ \\
\hline Intercept $\left(\ln \left(\alpha_{0}\right)\right)$ & -75.7805 & 6.6970 & -11.3160 & 0.0001 \\
$P O P_{O} \times I N D_{O}$ & 1.0270 & 0.0674 & 15.2490 & 0.0001 \\
$I N C_{O} \times M K_{O}$ & 1.1847 & 0.3023 & 3.9190 & 0.0004 \\
$T T_{T}$ & -2.9864 & 0.5027 & -5.9410 & 0.0001 \\
$C_{T}$ & -1.3674 & 0.1287 & -10.6210 & 0.0001 \\
$P O P_{D} \times I N D_{D}$ & 0.5097 & 0.0659 & 7.7320 & 0.0001 \\
$I N C_{D} \times M K_{D}$ & 3.3767 & 0.2931 & 11.5220 & 0.0001 \\
$T T_{R}$ & 1.8687 & 0.3553 & 5.2590 & 0.0001 \\
$C_{R}$ & 1.2316 & 0.5800 & 2.1340 & 0.0345 \\
\hline$D_{\text {od }}$ & 0.5708 & 0.0059 & 96.37 & 0.0001 \\
\hline
\end{tabular}

\section{$5.2 .5 \bigcirc$ Diagnostic Checking and Aptness}

When the parameters of a regression model are estimated for an application, one cannot usually be certain in advance that the model is appropriate for that application. To check model appropriateness and applicability, the fundamental assumptions underlying use of the regression analysis technique to develop that model should be validated. These assumptions are: the residuals are independent, they are normally distributed, have a mean of zero, a constant variance and are uncorrelated. If the model is appropriate for the data at hand, the observed residuals should then reflect these assumptions. This is why the residual analysis is considered by researchers as a highly useful means of examining the aptness of a model.

For the four developed models, residual analysis is carried out using three methods. The first method, to check if the residuals do have a constant variance, is residual plot against predicted values. The results, as shown in Figures 5.13 through 5.16, show that each model's residuals are of constant variance and do not have any significant pattern (i.e. they are randomly distributed and independent).

The second method is carried out by executing a Univariate analysis. The output, utilizing this $S A S$ software procedure, resulted in an output composed of two 
parts for each model, as shown in Tables 5.9 through 5.12. The upper part contains descriptive statistics while the lower part contains three graphic plots. By inspecting the information in each parts, the answer to the question of model appropriateness can be found.

The last line of the upper part shows the results of the formal test for normality. The entry labeled "D:Normal" gives the value of the test statistic. The upper part also includes statistics for the skewness and kurtosis for the residual distribution. The closer the value of the skewness and kurtosis statistics approach zero, the more the residual distribution approaches normality.

Other descriptive measures also given in this part of the output. These include: number of observation $N$, the mean, and the median (or $Q_{2}$ ) which separates the top $50 \%$ of a set of observation from the bottom $50 \%$. In a similar fashion, the first quartile, $Q_{1}$, is the value corresponding to the point below which $25 \%$ of the observations lie. The third quartile $\left(Q_{3}\right)$ is the value corresponding to the point above which $25 \%$ of the observations occur. Other measures are automatically shown in this output and they may be useful for other purposes rather than ours. To cite an example of these measures, Table 5.10 (for CMI) will be used. It can be clearly seen that the mean and the median values are $-1.505 \times 10^{-13}$ and 0.007 respectively and the value of skewness is -0.05 while the kurtosis value is -0.02 . Both of the indicated values, as well as the mean and median are very close to zero which is an indication of normality of the residuals distribution.

The lower part of Table 5.10 shows three different plots, namely: the Stem-andLeaf plot, the Box plot and the Normality plot. The Stem-and-Leaf plot shows the shape of the residuals distribution. By inspecting this plot for example, it is clearly seen that the shape of this plot is quite close to the normal distribution bell curve shape. The properties of this shape: it's mean, median, skewness and kurtosis are those given above. The second plot is the Box plot, as shown in Table 5.10. The upper and lower ends of the box indicate the 25 th percentile $\left(Q_{1}\right)$ and $75^{\text {th }}$ percentile $\left(Q_{3}\right)$ 
while the line inside the box (with an asterisk at each end) indicates the median, the $50^{\text {th }}$ percentile. The + located on the $50^{\text {th }}$ percentile line indicates the mean. If the median and the mean are the same, the + falls on the line across the box (as shown in this plot) which indicates the normality of the distribution. The third plot is the normality plot (labeled "Normal Probability Plot") composed of both asterisks (*) and plus signs $(+)$. The plus signs form a straight line. The asterisk signs represent the residuals. If the residuals are normally distributed, the asterisks form a straight line and thus cover most of the plusses. It is clear, from Tables 5.9 through 5.12 that most of the plus signs are covered by asterisks. This graphic display supports the assumption that the residuals are normally distributed.

To validated the assumption that the residuals are not correlated, the DurbinWatson test was utilized to test the residuals' autocorrelation for each of the four developed models. The Durbin-Watson autocorrelation procedure proved, at $95 \%$ level of confidence, that the residuals are not correlated. It can be concluded then by applying the different descriptive measures and plot inspections, that the results all support the validity of the regression assumptions and hence the appropriateness of the developed models.

In summary, the conclusions that can be drawn from this analysis are that the outcome of the pragmatic condition (negative elasticities and positive co-elasticities), statistical conditions (such as the coefficient of variation, the standard deviation, and the $\mathrm{t}$-values for the individual variables along with the $\mathrm{F}$-test, Maximum $R^{2}$ Improvement, Mallow's $C_{P}$ Statistic and Mean Squared Error procedures), and the independency and normality of the residuals all support the validity of the developed models and show that all eight variables in each model are statistically significant. 


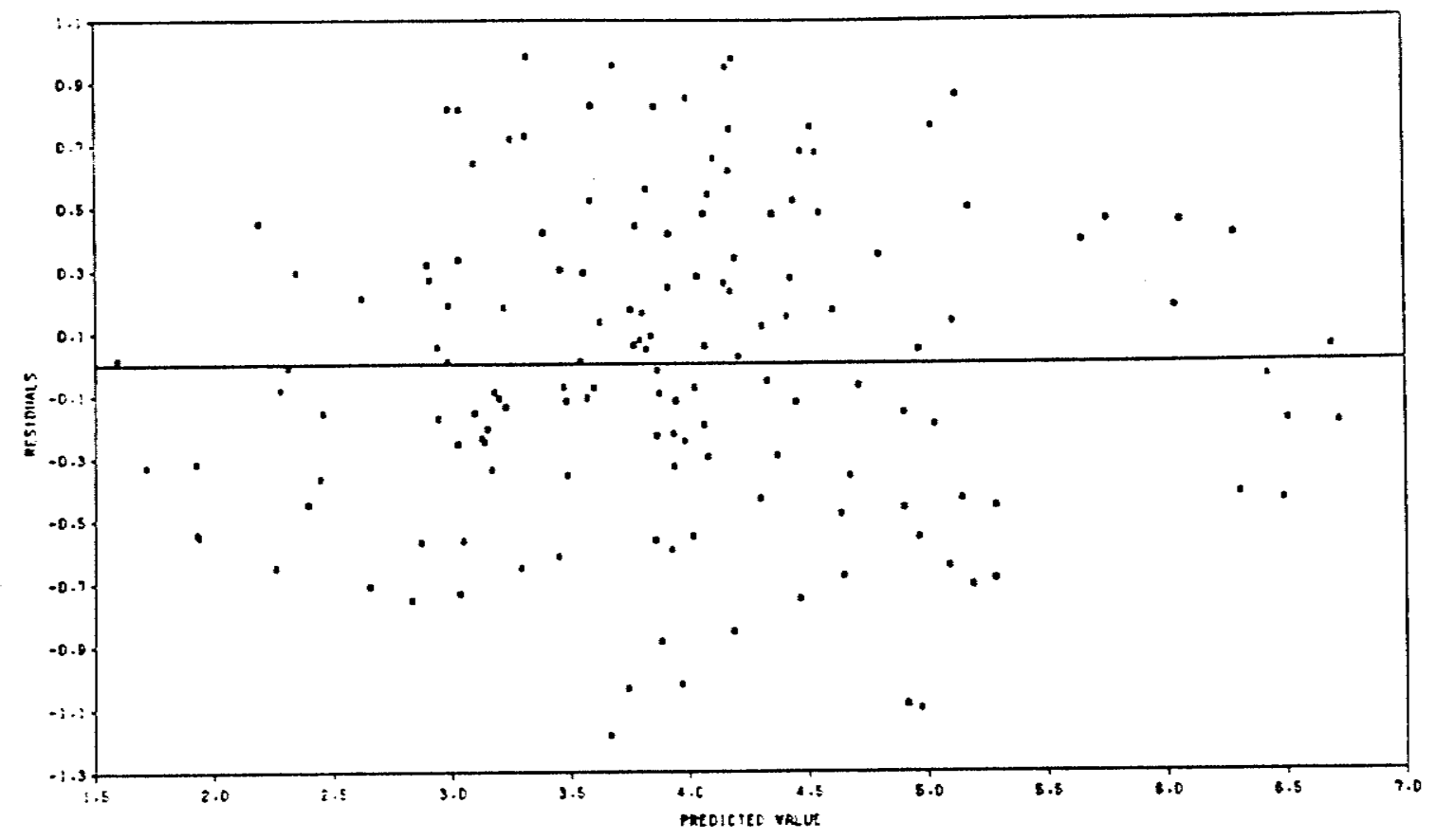

Figure 5.13 FFB\&T: Residuals Plot

Residuals vs. predicted values

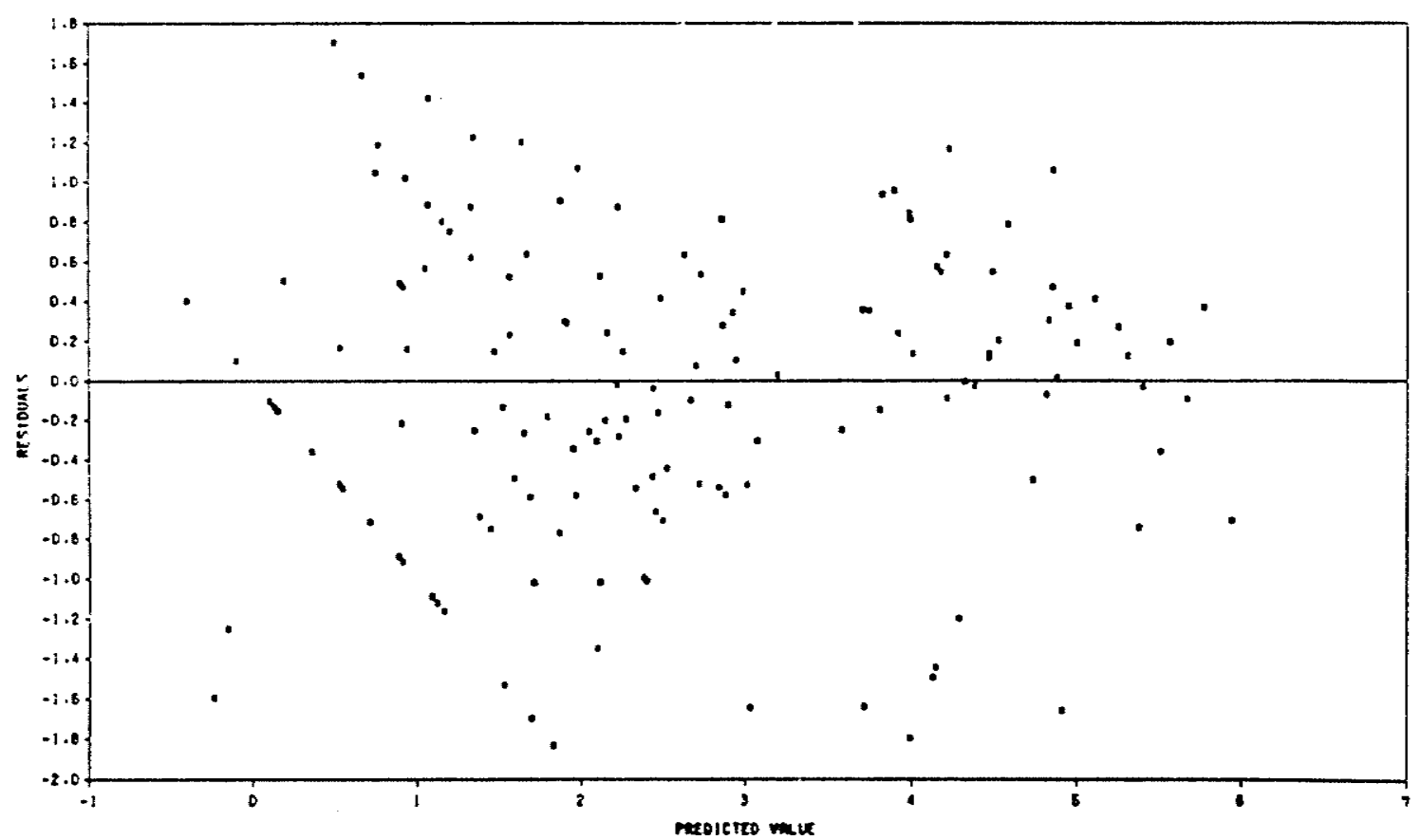

Figure 5.14 CMI: Residuals Plot

Residuals v's. predicted values 


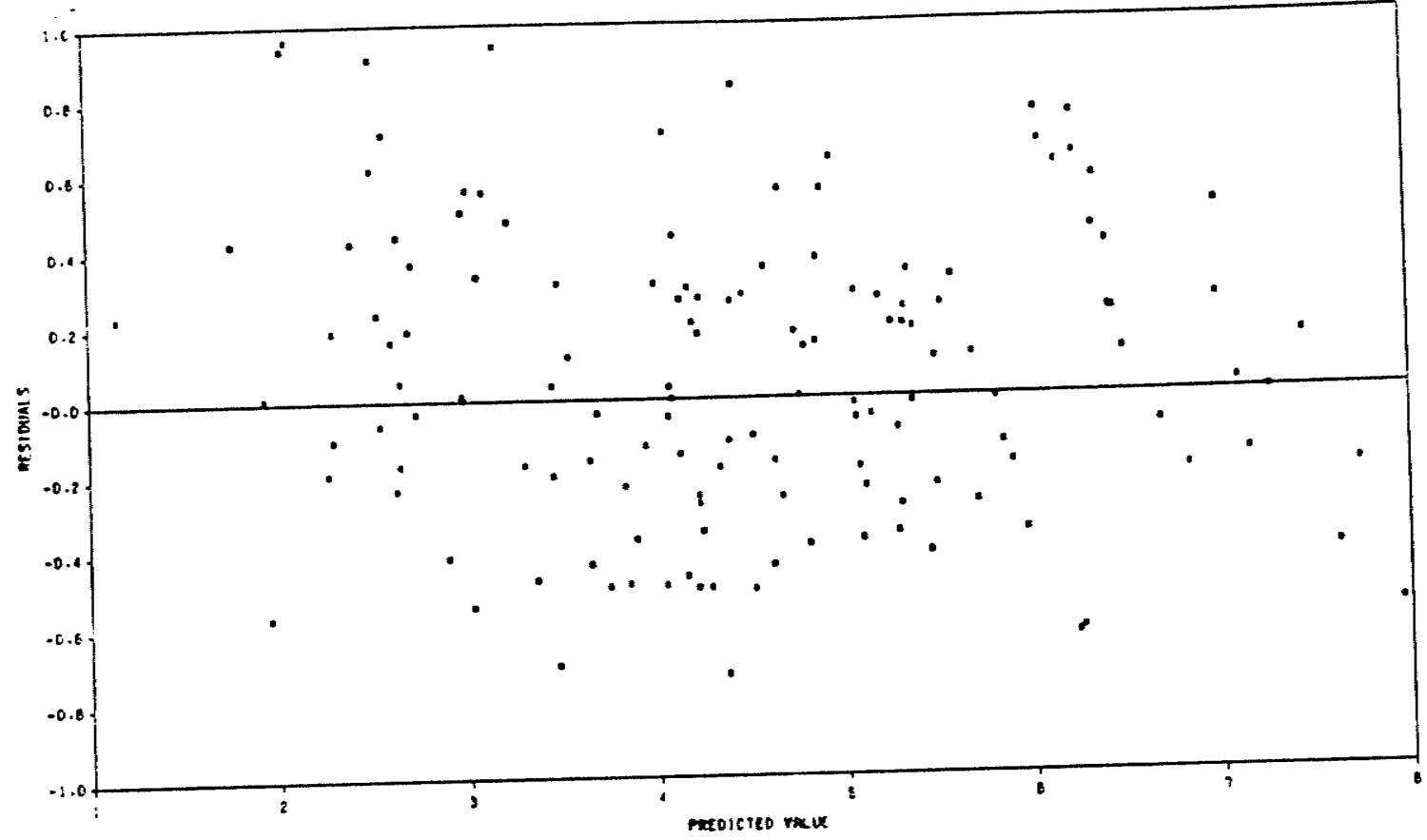

Figure 5.15 FMI: Residuals Plot

hesiduals v's. predicted values

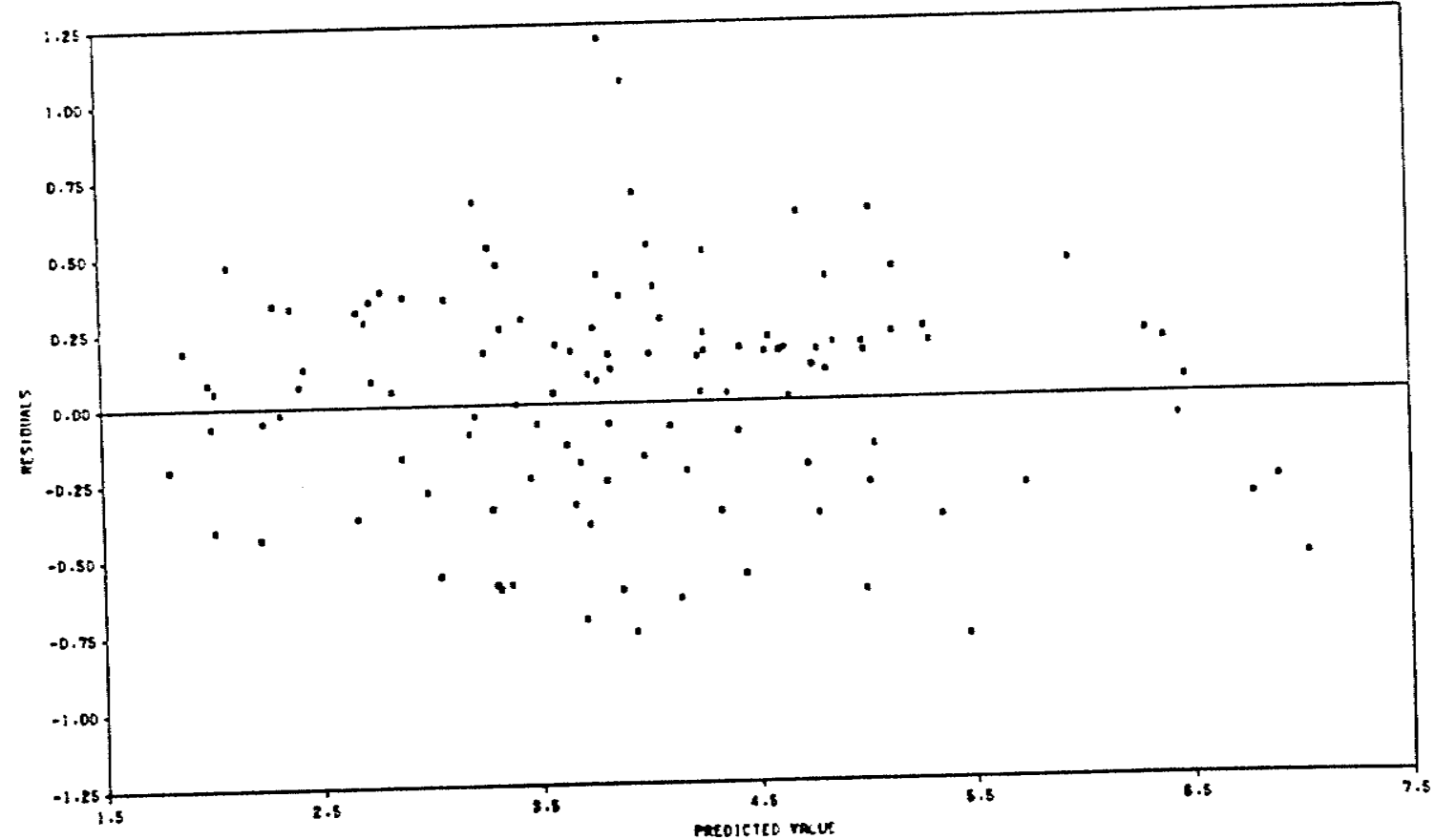

Figure 5.16 EPI: Residuals Plot

Residuals v's. predicted values 
UNIVARIATE

VAR I ABLE $=R$

RESIDUALS

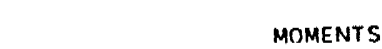

\begin{tabular}{|c|c|c|c|}
\hline N & & 150 & SUM WGTS \\
\hline $\begin{array}{l}\text { MEAN } \\
\text { SIU DE }\end{array}$ & & $-1.209 E-13$ & SUM \\
\hline $\begin{array}{l}\text { SIU DE } \\
\text { SKEWNE }\end{array}$ & & 0.523182 & VARI ANCE \\
\hline $\begin{array}{l}\text { SKEWNE } \\
\text { USS }\end{array}$ & Ess & -0.0521955 & KURTOSIS \\
\hline $\begin{array}{l}\text { USS } \\
\text { cV }\end{array}$ & & 40.7842 & css \\
\hline $\begin{array}{l}\text { CV } \\
\text { T:MEAN }\end{array}$ & & $\begin{array}{r}-99999 \\
\end{array}$ & STO MEAN \\
\hline $\begin{array}{l}\text { T: MEAN } \\
\text { SGN RA }\end{array}$ & $N=0$ & $\begin{array}{r}-2.831 E-12 \\
-2.5\end{array}$ & 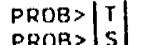 \\
\hline $\begin{array}{l}\text { SGN } R A \\
\text { NUM }\end{array}$ & $\begin{array}{l}\text { ANKK } \\
=0\end{array}$ & $\begin{array}{r}-2.5 \\
150\end{array}$ & $P R O B>|S|$ \\
\hline$D:$ NORA & MAL & 0.033664 & $P R O B>0$ \\
\hline STEM & I.EAF & & \\
\hline 11 & 15 & & 2 \\
\hline 10 & & & \\
\hline $\begin{array}{l}9 \\
8\end{array}$ & $\begin{array}{l}5688 \\
12235\end{array}$ & & 4 \\
\hline $\begin{array}{l}8 \\
7\end{array}$ & $\begin{array}{l}12235 \\
23568\end{array}$ & & \\
\hline 6 & 24578 & & 5 \\
\hline 5 & 02246 & & 5 \\
\hline 4 & 11245 & $55678 B$ & 10 \\
\hline 3 & 02345 & & 6 \\
\hline 2 & 1346 & 77899 & 9 \\
\hline 1 & 2335 & 677889 & 10 \\
\hline 0 & 11226 & 45556679 & 12 \\
\hline-0 & 9988 & 8776421 & 11 \\
\hline$-1 \leq$ & 97666 & 6422211 & 11 \\
\hline-2 & 65545 & 321000 & 10 \\
\hline-3 & 7664 & 33100 & \\
\hline-4 & 8665 & 4332 & \\
\hline-5 & 77765 & 554 & \\
\hline$-6 s$ & 9855 & 520 & $?$ \\
\hline-7 & 5531 & & \\
\hline-8 & 96 & & \\
\hline $\begin{array}{r}-9 \\
-10\end{array}$ & & & \\
\hline $\begin{array}{l}-10 \\
-11\end{array}$ & Bo & . & \\
\hline-12 & & & \\
\hline-13 & & & 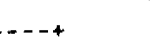 \\
\hline
\end{tabular}

MULTIPLY STEM.LEAF BY $10^{* *-0}$

4

\section{OUANT ILES $(D E F=4)$}

$\begin{array}{lrr}100 \% \text { MAX } & 1.15196 & 99 \% \\ 75 \% \text { O3 } & 0.395638 & 95 \% \\ 50 \% \text { MED } & -0.0160188 & 9 \\ 25 \% \text { O1 } & -0.356521 & 1 \\ \text { O\% MIN } & -1.35533 & \\ \text { RANGE } & 2.50729 & \\ \text { Q3 OO } & 0.75216 \\ \text { MUDE } & -1.35533 & \end{array}$

\section{$99 \% \quad 1.13166$}

0.853512
0.747479

0.747479
-0.677325

0.677325

$-1.26844$

40.7812 0427176

0.997006

$>.15$

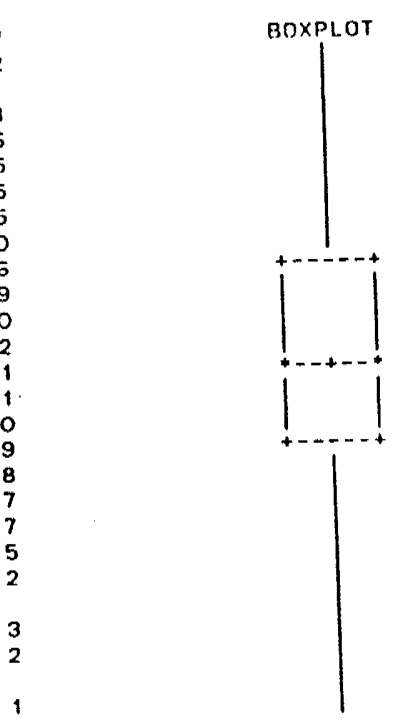

EXTREMES

LOWEST HIGHEST $-1.35533 \quad 0.955411$ $-1.184950 .976001$ $\begin{array}{rr}-1.10017 & 0.983005 \\ -1.08607 & 1.11216\end{array}$

$\begin{array}{rr}-1.08607 & 1.11216 \\ -1.03616 & 1.15196\end{array}$

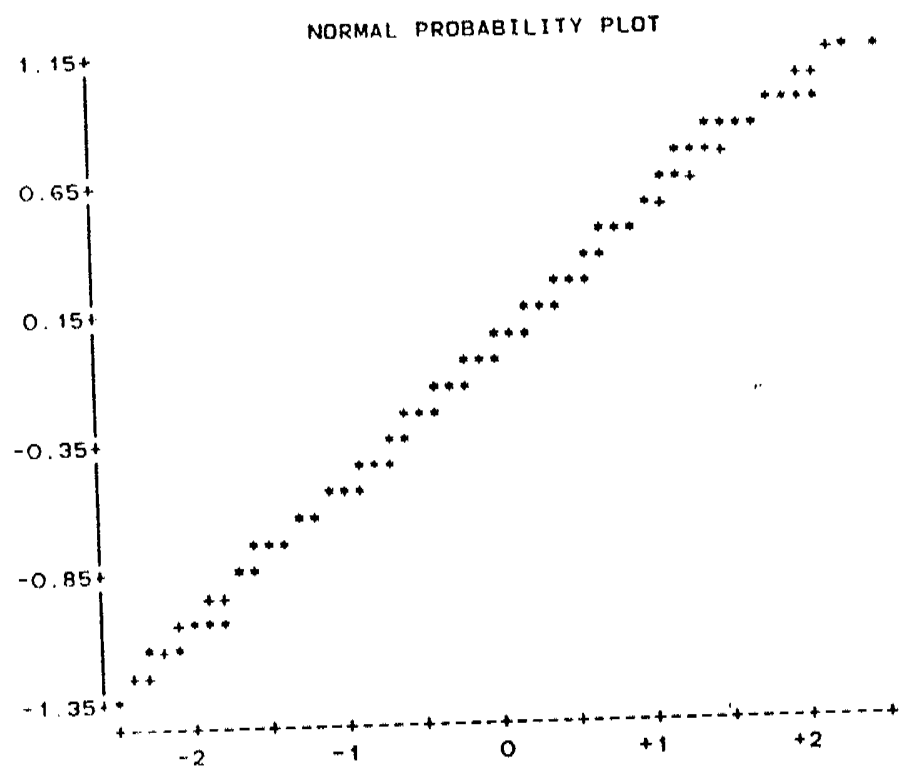

Table: 5.9 FFB\&T: Univariate Analysis 
VARIABLE $=R$

RESIDUALS

\section{MOMENTS}

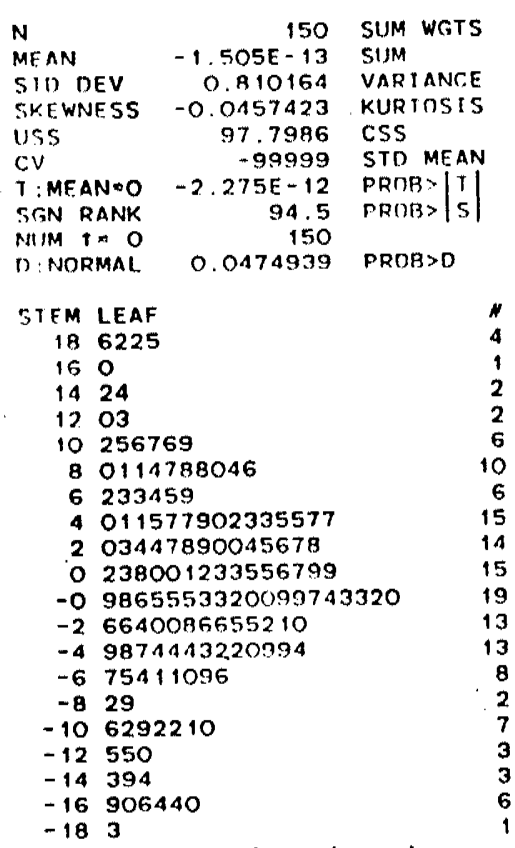

MULTIPLY STEM.LEAF BY $10 *-0$

\section{QUANTIIES(DEF $=4)$}

$\begin{array}{crr}100 \% \text { MAX } & 1.951 .35 & 99 \% \\ 75 \% \text { O3 } & 0.522493 & 95 \% \\ 50 \% \text { MED } & 0.00573157 & 90 \% \\ 25 \% \text { Q1 } & -0.523099 & 10 \% \\ 0 \% \text { MIN } & -1.83191 & 5 \% \\ \text { RANGE } & 3.78325 & 1 \% \\ \text { Q3-Q1 } & 1.04559 & \\ \text { MODE } & -1.83191 & \end{array}$

EXTREMES

LOWEST HIGHEST
-1.83191
1.70385

$\begin{array}{rr}-1.83191 & 1.70385 \\ -1.79465 & 1.86157 \\ -1.69632 & 1.91985\end{array}$

$-1.69632 \quad 1.91985$

$-1.65745 \quad 1.92218$

0.016407

97.7986

0.860006

$>.15$
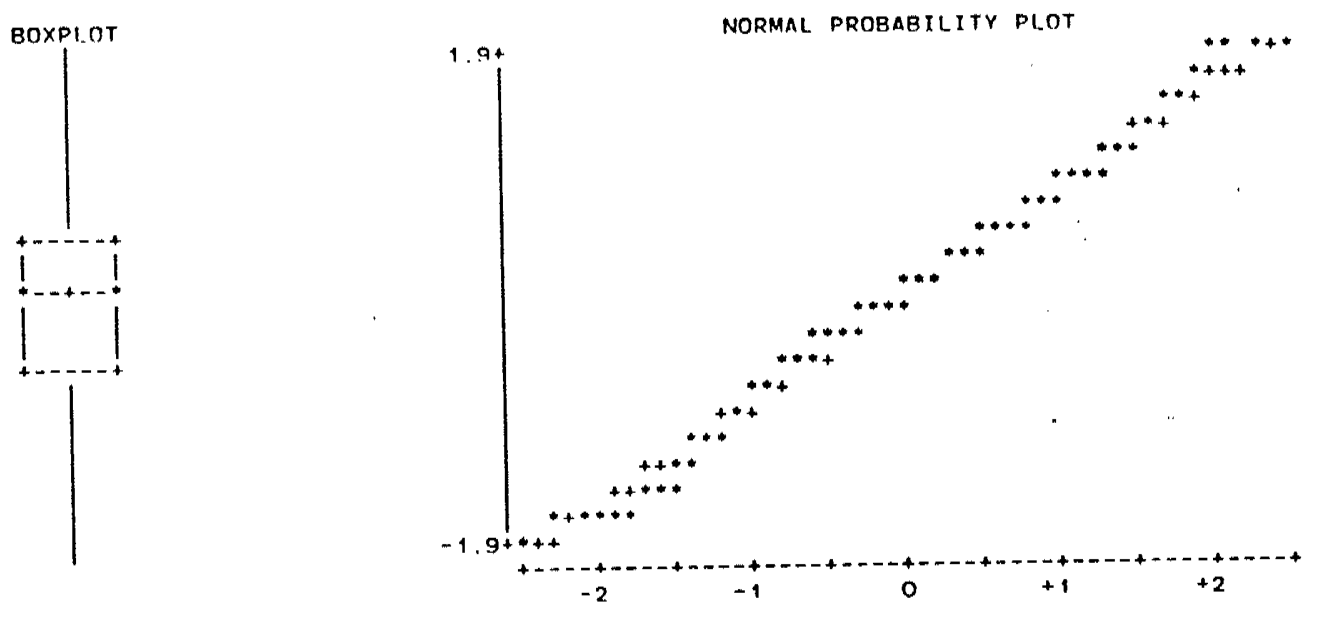

Table 5.10 CMI: Univariate Analysis 
UNIVARIATE

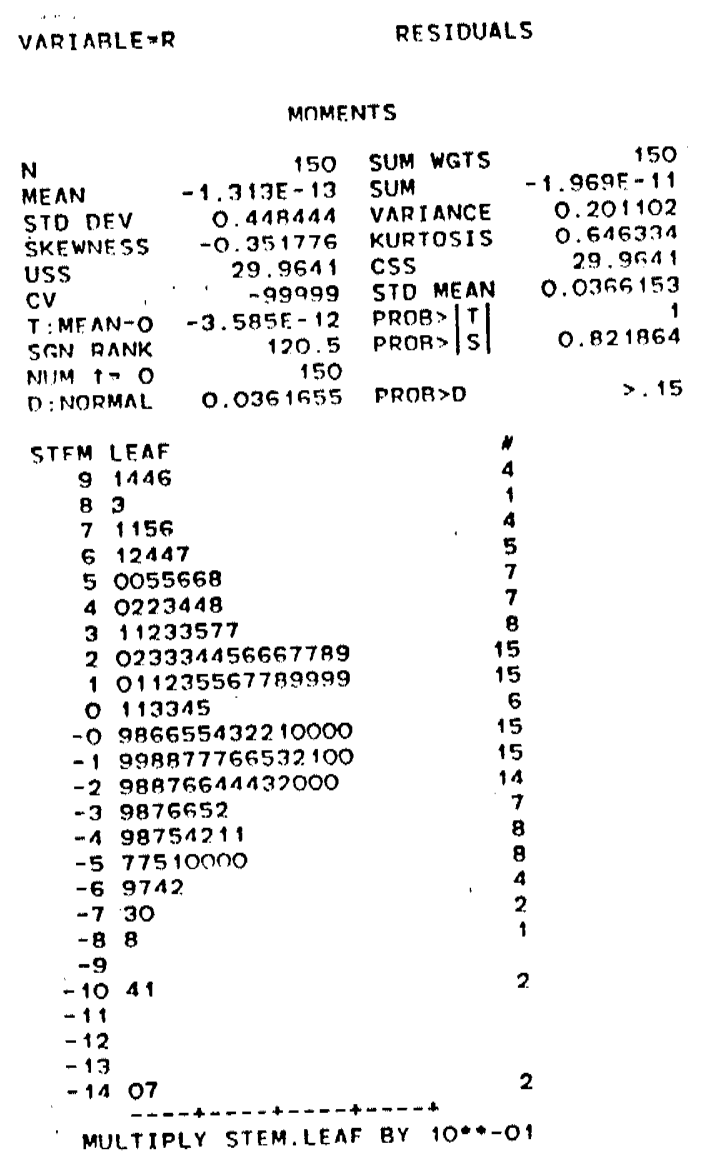

\begin{tabular}{|c|c|c|c|c|c|}
\hline \multicolumn{4}{|c|}{ QUANTILES(DEF-4) } & \multicolumn{2}{|c|}{ EXTRFMES } \\
\hline $100 \% \operatorname{MAX}$ & 0.952867 & $99 \%$ & 0.952356 & LOWEST & $\begin{array}{r}\text { HIGHFST } \\
0.832915\end{array}$ \\
\hline $75 \% 03$ & 0.282594 & $95 \%$ & 0.726449 & $-1,49659$ & $\begin{array}{l}0.832915 \\
0.911492\end{array}$ \\
\hline $50 \%$ Nice & .000808611 & $90 \%$ & 0.575031 & $\begin{array}{r}-1.0656 \\
-1.03757\end{array}$ & $\begin{array}{l}0.911437 \\
0.937979\end{array}$ \\
\hline $25 \% 21$ & -0.274229 & $\begin{array}{r}40 \% \\
5 \%\end{array}$ & $\begin{array}{l}-0.508199 \\
-0.693804\end{array}$ & -1.01372 & 0.947277 \\
\hline O\% MIN & -1.49659 & $1 \%$ & -1.48129 & -0.880361 & 0.962867 \\
\hline RANGF: & 2.45945 & & & & \\
\hline Q3-01 & 0.556823 & & & & \\
\hline & & & & & \\
\hline
\end{tabular}
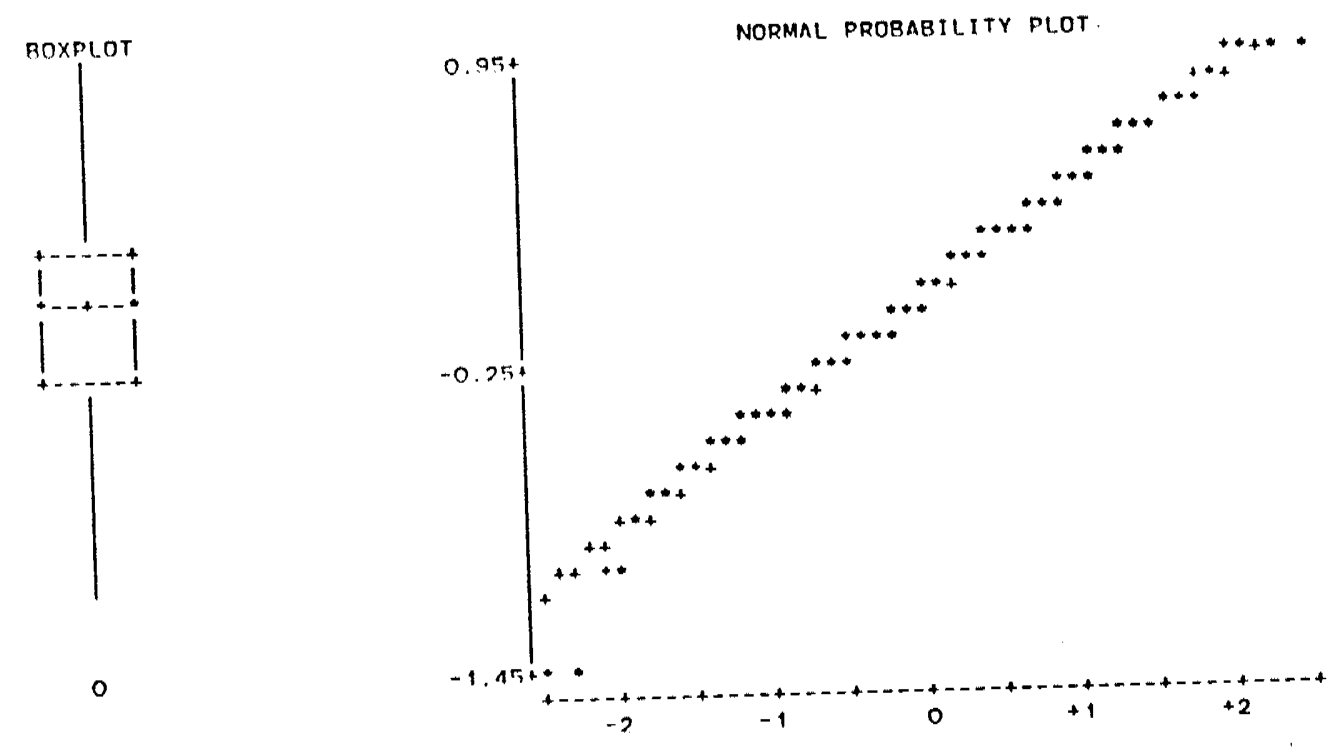

Table 5.11 FMI: Univariate Analysis 
INIVARIATE

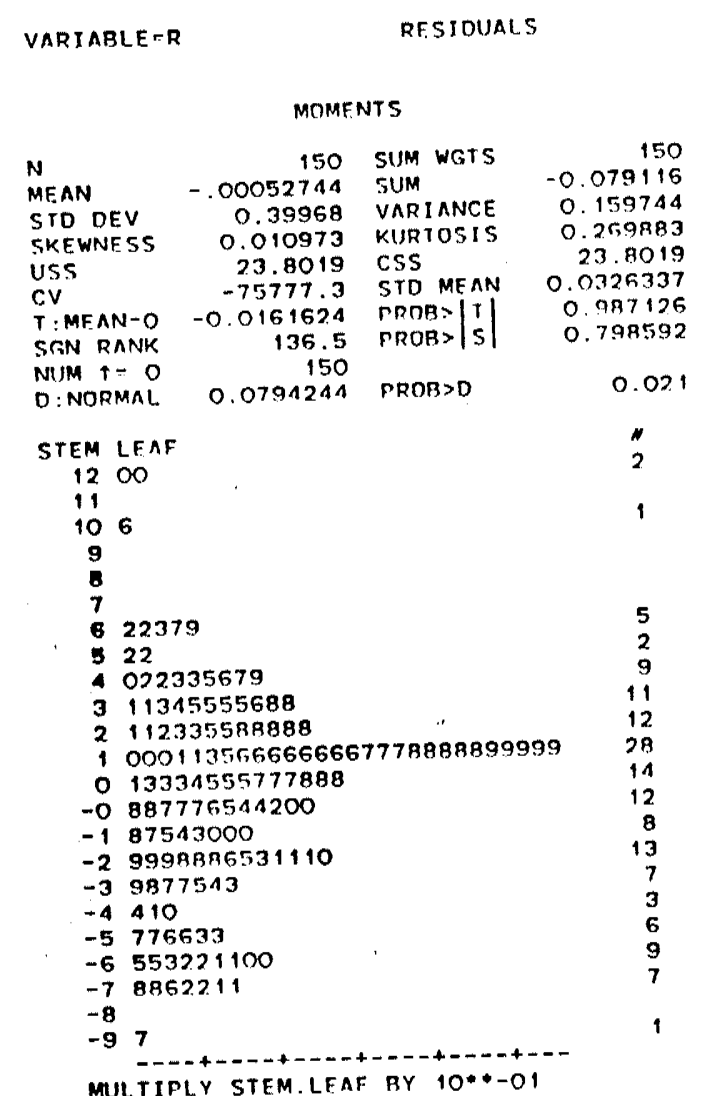

\begin{tabular}{|c|c|c|c|c|c|}
\hline \multicolumn{4}{|c|}{ OUANTILFS(DEF=A) } & \multicolumn{2}{|c|}{ EXTREMES } \\
\hline $100 \% \max$ & 1.19756 & $99 \%$ & 1.19755 & LOWE ST & $\begin{array}{r}\text { HJGH ST } \\
0 \quad 65035,9\end{array}$ \\
\hline $75 \%, 23$ & $0.239,445$ & $95 \%$ & 0.617357 & -0.970037 & $\begin{array}{l}0.653759 \\
0.689043\end{array}$ \\
\hline $50 \%$ MED & 0.0559289 & $90 \%$ & 0.433418 & $\begin{array}{l}-0.784373 \\
-0.78432 .3\end{array}$ & $\begin{array}{l}0.5800,3 \\
1.05699\end{array}$ \\
\hline $25 \% 01$ & -0.28052 .7 & $10 \%$ & -0.610412 & $\begin{array}{l}-0.784 .121 \\
-0.750046\end{array}$ & 1. 19755 \\
\hline O\% MIN & -0.070097 & $\begin{array}{l}5 \% \\
1 \%\end{array}$ & $\begin{array}{l}-0.708768 \\
-0.875353\end{array}$ & -0.715579 & $1.1975,5$ \\
\hline $\begin{array}{l}\text { PANGE } \\
\text { Q.3-0 } \\
\text { MUDE }\end{array}$ & $\begin{array}{r}2.15765 \\
0.517072 \\
-0.781323\end{array}$ & & & & \\
\hline
\end{tabular}
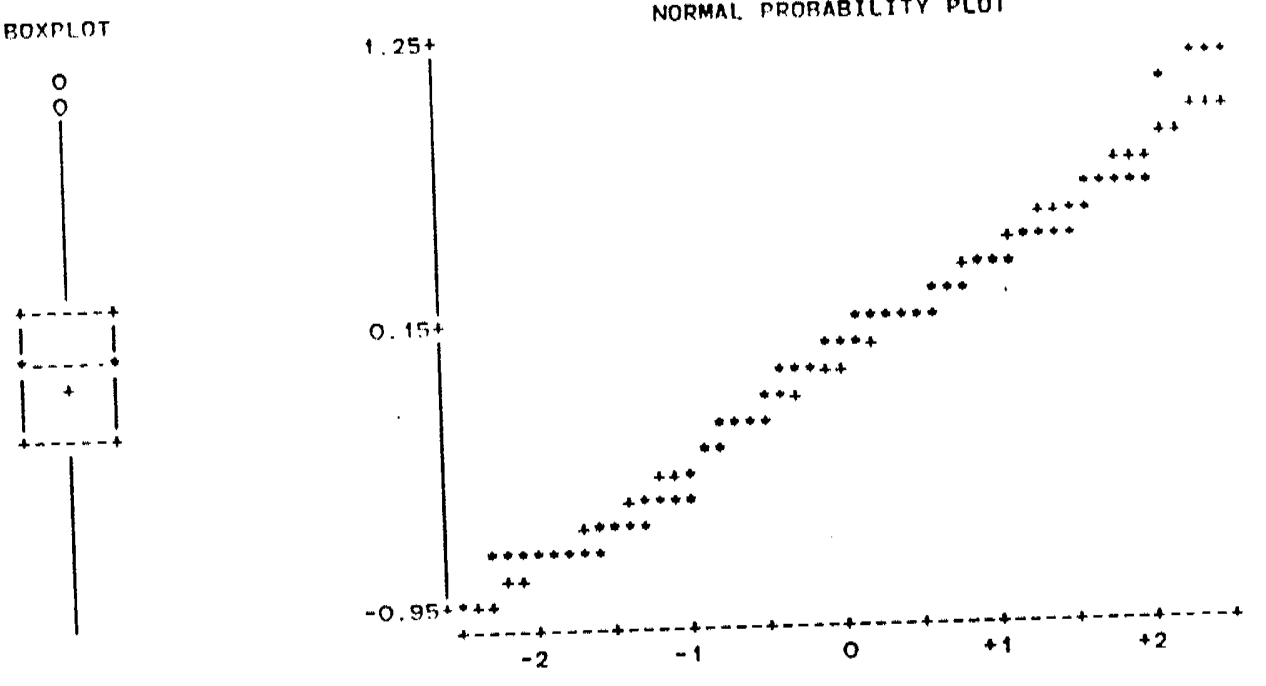

Table 5.12 EPI: Univariate Analysis 
CHAPTER 6

\section{IMPACTS OF VWD REFORM}

\section{$6.1 \diamond$ Impact on Trucking}

The 1987 RTAC report examined the potential impact on trucking costs for each of the four vehicle weight and dimension regulation scenarios it studied. The report based its examination on freight in two categories, high density commodities affected primarily by weight restrictions, and low density shipments affected by dimension limitations. These were identified as 'weight-out commodities' and 'cubeout commodities' respectively. No distinction was made by RTAC between individual commodities or commodity types. Since VWD regulations are relaxed under the scenarios, greater payloads can be carried in fewer trips resulting in reductions in trucking costs. Any trucking cost reductions depend chiefly upon the relaxation of weight and dimension regulations, and for each of the four scenarios proposed, RTAC tabulated the reductions in trucking costs which would result.

As previously noted, data from Scenarios D and C of the RTAC report correspond to the National and Western Agreements respectively except for small differences in the length of the commodity carrying boxes (total weight, weight per axle 
are the same in each case). Consequently, the trucking cost reductions developed by RTAC for scenarios D and C simulate the effects of the National and Western VWD agreements and will be used subsequently to determine the impact of trucking cost reductions on rail/truck modal split. Table 6.1 contains the total trucking cost reduction percentages predicted by RTAC for weight-out commodities at the completion of the truck conversion process.

\section{Table 6.1 RTAC Trucking Cost Reductions (\%) Weight-out Commodities}

\begin{tabular}{lrrrrrrrrrr}
\hline O: $\backslash$ D: Nfld & P.E.I. & N.S. & N.B. & Que. & Ont. & Man. & Sask. & Alta & B.C. \\
\hline Nfld & & 9 & 9 & 9 & 9 & 9 & 20 & 20 & 20 & 20 \\
P.E.I. & 9 & & 9 & 9 & 9 & 9 & 36 & 36 & 36 & 36 \\
N.S. & 9 & 9 & & 9 & 9 & 9 & 20 & 20 & 20 & 20 \\
N.B. & 9 & 9 & 9 & & 6 & 6 & 8 & 13 & 13 & 13 \\
Que. & 9 & 9 & 9 & 6 & & 10 & 8 & 13 & 13 & 13 \\
Ont. & 9 & 9 & 9 & 6 & 10 & & 8 & 14 & 14 & 14 \\
Man. & 20 & 36 & 20 & 8 & 8 & 8 & & 15 & 15 & 15 \\
Sask. & 20 & 36 & 20 & 13 & 13 & 14 & 15 & & 15 & 15 \\
Alta & 20 & 36 & 20 & 13 & 13 & 14 & 15 & 15 & & 15 \\
B.C. & 20 & 36 & 20 & 13 & 13 & 14 & 15 & 15 & 15 & \\
\hline
\end{tabular}

National Agreement

Western Agreement

For cube-out commodities, RTAC predicted that trucking costs would fall by $20 \%$ for interprovincial shipments among the western provinces; by $9 \%$ for shipments between Ontario and Quebec; by $10 \%$ for shipments originating or terminating in Prince Edward Island; and by $12 \%$ for all other O-D pairs.

The model formation structure expressed in equation [5.2] gives the model its ability to be applied in a modal shift role. By determining trucking volumes using the developed model and the new service characteristics of both trucking and rail modes, the effect of these new characteristics can be studied. Reductions in trucking user costs represent the effects of VWD reform, and similar adjustments in rail service 
characteristics simulate the response of the railways to keep their market share. The percentage response was determined by using equation [5.2], the elasticities and the co-elasticities estimated for each commodity section (Tables 5.5 through 5.8), and the RTAC trucking cost reductions (Table 6.1).

Although the model development process involved the use of data collected for only the six central and western provinces, (a sample from the total of ten Canadian provinces $)^{*}$ these models can be applied for the purpose of calculating the impacts of the new VWD regulations on the railway freight transportation that arises from all Canadian interprovincial freight movement.

\section{$6.2 \diamond$ Impact on Railways}

The relationship between VWD reform and the railway industry is dependent upon the translation of improved trucking industry economics into more competitive rates for freight shippers. The trucking cost reductions reported by RTAC represent the eventual industry savings when the entire fleet has been converted to conform with the new regulations. The conversion process will likely occur gradually, over a ten year time frame, through the 1990's and complete conversion will likely not occur "even in the long term." RTAC themselves stated: "The percentages ... may therefore be interpreted as the 'upper bound' of trucking rate reductions that might be faced by the railways..." When interviewed, the Chief Executive Officer of one national trucking company stated that fleet conversion was only just getting underway, and full adherence to the new weights and dimensions would not be complete before the turn of the century. The ten year adjustment period has been also reported by Clayton \& Lai, 1986.

The developed models were applied to the analysis of the rail impacts of VWD reform by changing the values of the truck service characteristics as determined by RTAC for the appropriate link. The increase due to the effects of VWD reform on

* This sample of traffic includes more than $80 \%$ of interprovincial railway and trucking tonnage and revenue. 
trucking tonnage were analysed. The rail response was determined using the same models, by revaluing the rail service characteristics to restore the modal split to the pre-agreement levels. These new values for rail user cost and rail travel time form the basis for the ensuing analysis.

The 1988 VWD regulations are expected to have impacts on the trucking and railway freight transportation modes. They will facilitate an increased efficiency in trucking operation and hence, reduce operating costs. Greater efficiency in the transportation of interprovincial loads, without the hinderance of differing vehicle restrictions may also result in better door-to-door travel times. Reduction in operating costs and/or shorter door-to-door travel times will in turn increase the trucking revenue.

Conversely, railway revenue will decrease, especially for those links where both modes hold substantial shares of traffic. As the trucking industry translates lower costs into lower rates, shippers (users) will be attracted to it, diverting business from rail. Railways possess a continuum of responses ranging from lowering rates, reduction in door-to-door travel time, or combination of both that would be enough to retain all of their existing market share. The railway industry may also chose not to react and to accept a loss in traffic to the competition as a result of VWD regulatory reform. The degree of rail revenue loss that might occur depends chiefly on the level of trucking rate reduction and the proportion of existing rail tomnage that will divert from rail to truck by improving the latter's attractiveness. The railway industry will likely expend substantial effort to maintain its market share over those links where earnings are significant. On the other hand, they will likely make little effort to maintain traffic over unprofitable or poorly performing links. The abandonment of service in some areas will likely result.

For each of the four commodity sections modeled, the railway rate reduction percentages that would match trucking rate reductions were determined and spread over the anticipated ten year adjustment period. These values were developed by using the models' elasticities and the RTAC trucking cost reductions. 


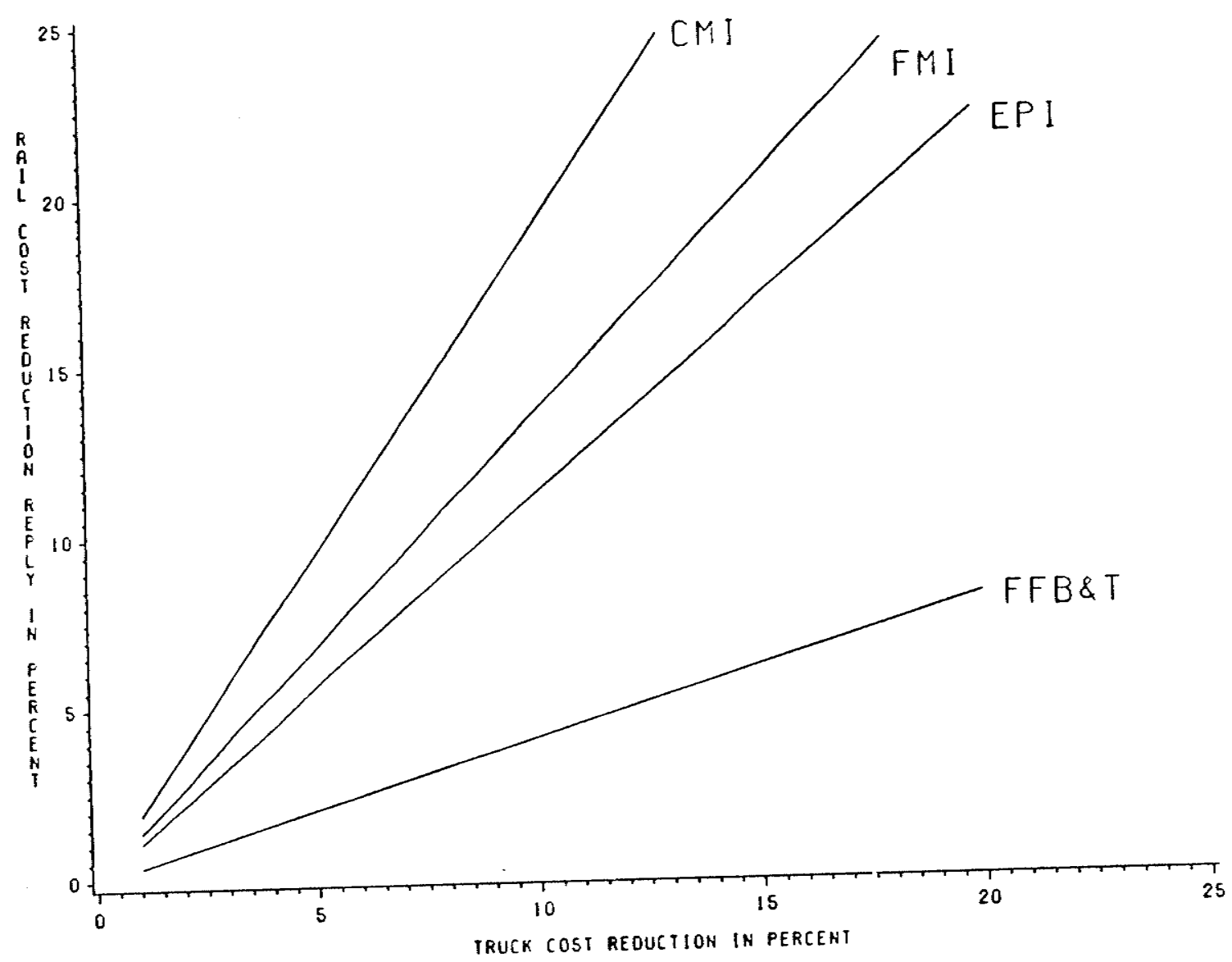

Figure 6.1 Cost Reductions

The relationship between trucking rate reductions and rail rate reductions, to keep the freight market share, for the four commodity sections modelled are shown in Figure 6.1. In this figure the ratio of rail rate reduction to truck rate reduction. differs sharply from section to section. The railways' strongest position, in rail rate reductions terms, is with respect to the FFB\&T section, where, for example, a $10 \%$ reduction in truck rates could be met effectively by a reduction in rail rates of approximately $4.0 \%$. In the case of freight classified under the categories EPI and FMI, the reduction in rail rates to effectively compete with trucking reductions are of nearly. equal percentages. A $10 \%$ reduction in trucking rates could be countered by an $11.0 \%$ 
reduction in rail rates for EPI and and $13.0 \%$ reduction for FMI. The competitive position of the rail industry with respect to CMI freight is more difficult. A $10 \%$ reduction in trucking rates for this class of freight would require a $18.5 \%$ reduction in corresponding rail rates.

The commodity section FFB\&T is a special case in terms of modal split, and does warrant special mention when comparing mode shift and rate reductions. The types and nature of "Food, feed, beverages and tobacco" class freight carried by the railways differs sharply with trucking. For rail, this section is composed almost exclusively by barley, corn, oats, rice, wheat and other cereals. For trucks, the variety of freight carried under the description FFB\&T is largely fruit and vegetables such as apples, bananas, grapes, watermelons, cantaloupes, peaches, pears, and tomatoes, and such other freight as meat and fish, cheese, beverages, and tobacco and cigarettes. This division between modes is dependent in particular upon the door-to-door delivery time requirements of perishable goods. The elasticities of the FFB\&T model exhibits the effects of these differences. They suggest, as mentioned above, that ir order to attract freight tonnage currently shipped by truck, rail rates would have to fall by $4.0 \%$ for every $10 \%$ that truck rates were reduced. Nevertheless, this most likely will affect food types where shipping cost is a more significant deciding factor than time. Where the value of the food type is highly time-dependent, such as for perishable food, the greater deciding factor will be the door-to-door travel time rather than the shipping cost. The food model shows that each $10 \%$ reduction in trucking door-todoor travel time has to be matched by $38 \%$ reduction in rail's door-to-door travel time for rail to keep its market share. The conclusion that can be drawn from this is that price is not a key competitive factor in the shipper's selection of a mode for the interprovincial transportation of FFB\&T freight. The existing mode split is fixed by mode characteristics other than price, and is unlikely to shift significantly as a result of VWD reform. 


\subsection{1 $\diamond$ Link-by-Link Rail Cost and Travel Time Reductions}

The link-by-link railways user cost reduction, for the four commodity sections are tabulated below. As discussed above, these values were generated using the corresponding commodity models and RTAC trucking cost reductions. Once the rail reductions were determined, they were spread over the anticipated ten year trucking adjustment period. The reductions in trucking user costs represent the effects of VWD reform, and similar adjustments in rail service characteristics simulate the response of the railways to keep their market share.

For the FFB\&T commodity classification, Table 6.2 presents competitive percentage reductions in annual railway user costs which will maintain the status quo modal split as VWD regulations affect the trucking industry.

\section{Table 6.2 FFB\&T Annual Railway Cost Reductions (\%) Weight-out Commodities}

\begin{tabular}{lrrrrrrrrrr}
\hline O: $\backslash$ D: Nfld* & P.E.I. & N.S. & N.B. & Que. & Ont. & Man. & Sask. & Alta & B.C. \\
\hline Nfld $^{*}$ & & 0.4 & 0.4 & 0.4 & 0.4 & 0.4 & 0.9 & 0.9 & 0.9 & 0.9 \\
P.E.I. & 0.4 & & 0.4 & 0.4 & 0.4 & 0.4 & 1.8 & 1.8 & 1.8 & 1.8 \\
N.S. & 0.4 & 0.4 & & 0.4 & 0.4 & 0.4 & 0.9 & 0.9 & 0.9 & 0.9 \\
N.B. & 0.4 & 0.4 & 0.4 & & 0.3 & 0.3 & 0.3 & 0.6 & 0.6 & 0.6 \\
Que. & 0.4 & 0.4 & 0.4 & 0.3 & & 0.4 & 0.3 & 0.6 & 0.6 & 0.6 \\
Ont. & 0.4 & 0.4 & 0.4 & 0.3 & 0.4 & & 0.3 & 0.6 & 0.6 & 0.6 \\
Man. & 0.9 & 1.8 & 0.9 & 0.3 & 0.3 & 0.3 & & 0.7 & 0.7 & 0.7 \\
Sask. & 0.9 & 1.8 & 0.9 & 0.6 & 0.6 & 0.6 & 0.7 & & 0.7 & 0.7 \\
Alta & 0.9 & 1.8 & 0.9 & 0.6 & 0.6 & 0.6 & 0.7 & 0.7 & & 0.7 \\
B.C. & 0.9 & 1.8 & 0.9 & 0.6 & 0.6 & 0.6 & 0.7 & 0.7 & 0.7 & \\
\hline
\end{tabular}

National Agreement

* No local rail service.

Western Agreement

Another way for the railways to compete with lower trucking user costs is with faster door-to-door travel times. Table 6.3 contains the annual percentage reductions in door-to-door travel times that would maintain the present modal split in the face of the lower trucking user costs expected from VWD reform. The procedure for 
Table 6.3 FFB\&T Annual Railway Travel Time Reductions (\%) Weight-out Commodities

\begin{tabular}{|c|c|c|c|c|c|c|c|c|c|c|}
\hline $\mathrm{O}: \backslash \mathrm{D}:$ & $f l d^{*}$ & P.E.I.* & N.S. & N.B. & Que. & Ont. & Man. & Sask. & Alta & B.C. \\
\hline Nfld $^{*}$ & & 0.6 & 0.6 & 0.6 & 0.6 & 0.6 & 1.5 & 1.5 & 1.5 & 1.5 \\
\hline P.E.I.* & 0.6 & & 0.6 & 0.6 & 0.6 & 0.6 & 2.9 & 2.9 & 2.9 & 2. \\
\hline N.S. & 0.6 & 0.6 & & 0.6 & 0.6 & 0.6 & 1.5 & 1.5 & 1.5 & 1.5 \\
\hline N.B. & 0.6 & 0.6 & 0.6 & & 0.4 & 0.4 & 0.6 & 0.9 & 0.9 & 0.9 \\
\hline Que. & 0.6 & 0.6 & 0.6 & 0.4 & & 0.7 & 0.6 & 0.9 & 0.9 & 0.9 \\
\hline Ont. & 0.6 & 0.6 & 0.6 & 0.4 & 0.7 & & 0.6 & 1.0 & 1.0 & 1.0 \\
\hline Iall. & 1.5 & 2.9 & 1.5 & 0.6 & 0.6 & 0.6 & & 1.1 & 1.1 & 1. \\
\hline Sask. & 1.5 & 2.9 & 1.5 & 0.9 & 0.9 & 1.0 & 1.1 & & 1.1 & 1.1 \\
\hline Alta & 1.5 & 2.9 & 1.5 & 0.9 & 0.9 & 1.0 & 1.1 & 1.1 & & 1. \\
\hline B.C. & 1.5 & 2.9 & 1.5 & 0.9 & 0.9 & 1.0 & 1.1 & 1.1 & 1.1 & \\
\hline
\end{tabular}

National Agreement

Western Agreement

* No local rail service.

generating the results in Table 6.3 is analogous to that used for Table 6.2.

Railway competitive response will likely take the form of some combination of reduction in real cost rates and some improvement in door-to-door travel times. For example, the results show that the trucking rate reductions between Ontario and Alberta could be countered by a $0.30 \%$ annual reduction in real (uninflated) user costs and a $0.50 \%$ annual shortening of rail door-to-door travel times (over the ten year period). This combined action would be an alternative to reducing rail user costs by $0.60 \%$ annually or shortening rail travel times by $1.0 \%$ annually.

For the cube-out items of this commodity the model was applied to determine the resulting railway competitive response, in the form of annual reductions in user costs or door-to-door travel times. This is detailed in Table 6.4.

Statistics for railway response in the instance of shipments to and from Newfoundland and Prince Edward Island have been included in Tables $6.2 \& 6.3$ in spite of the fact that rail service in those provinces has been abandoned. These values remain relevant because the railway industry will continue to compete with trucking through multi-modal transportation methods. These percentages reductions are also 
Table 6.4 FFB\&T Competing Railway Service Improvements Cube-out Commodities

\begin{tabular}{lcc}
\hline Movements: & $\begin{array}{c}\text { Annual Railway Reductions } \\
\text { User Cost }\end{array}$ & Travel Time \\
\hline Interprovincial movements among the west- & $0.89 \%$ & $1.48 \%$ \\
ern provinces & & \\
Shipments between Ontario and Quebec & $0.38 \%$ & $0.63 \%$ \\
Shipments to/from P.E.I. & $0.42 \%$ & $0.70 \%$ \\
All other interprovincial links & $0.51 \%$ & $0.85 \%$ \\
\hline
\end{tabular}

reported for the other three commodity sections for the same reason.

For the commodity section CMI, Table 6.5 presents competitive percentage reductions in annual railway user costs which will maintain the status quo modal split as VWD regulations affect the trucking industry.

\section{Table 6.5 CMI Annual Railway Cost Reductions (\%) Weight-out Commodities}

\begin{tabular}{lrrrrrrrrrr}
\hline O: $\backslash$ D: Nfld* & P.E.I.* & N.S. & N.B. & Que. & Ont. & Man. & Sask. & Alta & B.C. \\
\hline Nfld* & & 1.8 & 1.8 & 1.8 & 1.8 & 1.8 & 4.1 & 4.1 & 4.1 & 4.1 \\
P.E.I* & 1.8 & & 1.8 & 1.8 & 1.8 & 1.8 & 8.1 & 8.1 & 8.1 & 8.1 \\
N.S. & 1.8 & 1.8 & & 1.8 & 1.8 & 1.8 & 4.1 & 4.1 & 4.1 & 4.1 \\
N.B. & 1.8 & 1.8 & 1.8 & & 1.2 & 1.2 & 1.6 & 2.6 & 2.6 & 2.6 \\
Que. & 1.8 & 1.8 & 1.8 & 1.2 & & 2.0 & 1.6 & 2.6 & 2.6 & 2.6 \\
Ont. & 1.8 & 1.8 & 1.8 & 1.2 & 2.0 & & 1.6 & 2.8 & 2.8 & 2.8 \\
Man. & 4.1 & 8.1 & 4.1 & 1.6 & 1.6 & 1.6 & & 3.0 & 3.0 & 3.0 \\
Sask. & 4.1 & 8.1 & 4.1 & 2.6 & 2.6 & 2.8 & 3.0 & & 3.0 & 3.0 \\
Alta & 4.1 & 8.1 & 4.1 & 2.6 & 2.6 & 2.8 & 3.0 & 3.0 & & 3.0 \\
B.C. & 4.1 & 8.1 & 4.1 & 2.6 & 2.6 & 2.8 & 3.0 & 3.0 & 3.0 & \\
\hline
\end{tabular}

National Agreement

Western Agreement

* No local rail service.

Here again, another potential method for the railways to compete with lower trucking user costs is with faster door-to-door travel times. Table 6.6 contains the annual percentage reductions in door-to-door travel times that would maintain the 
present modal split in the face of the lower trucking user costs expected from VWD reform. The same procedure for generating the results in Table 6.5 is used to generate Table 6.6.

\section{Table 6.6 CMI Annual Railway Travel Time Reductions (\%) Weight-out Commodities}

\begin{tabular}{lrrrrrrrrrr}
\hline O: $\backslash$ D: & Nfld* & P.E.I. & N.S. & N.B. & Que. & Ont. & Man. & Sask. & Alta & B.C. \\
\hline Nfld $^{*}$ & & 0.4 & 0.4 & 0.4 & 0.4 & 0.4 & 0.9 & 0.9 & 0.9 & 0.9 \\
P.E.I. & 0.4 & & 0.4 & 0.4 & 0.4 & 0.4 & 1.8 & 1.8 & 1.8 & 1.8 \\
N.S. & 0.4 & 0.4 & & 0.4 & 0.4 & 0.4 & 0.9 & 0.9 & 0.9 & 0.9 \\
N.B. & 0.4 & 0.4 & 0.4 & & 0.2 & 0.2 & 0.3 & 0.6 & 0.6 & 0.6 \\
Que. & 0.4 & 0.4 & 0.4 & 0.2 & & 0.5 & 0.3 & 0.6 & 0.6 & 0.6 \\
Ont. & 0.4 & 0.4 & 0.4 & 0.2 & 0.5 & & 0.3 & 0.6 & 0.6 & 0.6 \\
Man. & 0.9 & 1.8 & 0.9 & 0.3 & 0.3 & 0.3 & & 0.7 & 0.7 & 0.7 \\
Sask. & 0.9 & 1.8 & 0.9 & 0.6 & 0.6 & 0.6 & 0.7 & & 0.7 & 0.7 \\
Alta & 0.9 & 1.8 & 0.9 & 0.6 & 0.6 & 0.6 & 0.7 & 0.7 & & 0.7 \\
B.C. & 0.9 & 1.8 & 0.9 & 0.6 & 0.6 & 0.6 & 0.7 & 0.7 & 0.7 & \\
\hline
\end{tabular}

\section{National Agreement}

Western Agreement

* No local rail service.

Railway competitive response will likely take the form of some combination of reduction in real cost rates and some improvement in door-to-door travel times. For example, the results show that the trucking rate reductions between Alberta and Ontario could be countered by a $1.40 \%$ annual reduction in real (uninflated) user costs and a $0.30 \%$ annual shortening of rail door-to-door travel times (over the ten year period). This combined action would be an alternative to reducing rail user costs by $2.80 \%$ annually or shortening rail travel times by $0.60 \%$ annually.

Using the RTAC trucking cost reduction percentages for cube-out commodities, the model was applied to determine the resulting railway competitive response in the form of annual reductions in user costs or door-to-door travel times. The figures generated are reported in Table 6.7.

Table 6.8 presents competitive percentage reductions in annual railway user 
Table 6.7 CMI Competing Railway Service Improvements Cube-out Commodities

\begin{tabular}{lcc}
\hline Movements: & $\begin{array}{c}\text { Annual Railway Reductions } \\
\text { User Cost }\end{array}$ & $\begin{array}{c}\text { Travel Time } \\
\text { Interprovincial movements among the west- }\end{array}$ \\
ern provinces & $4.13 \%$ & $0.88 \%$ \\
Shipments between Ontario and Quebec & $1.77 \%$ & $0.37 \%$ \\
Shipments to/from P.E.I. & $1.99 \%$ & $0.42 \%$ \\
All other interprovincial links & $2.39 \%$ & $0.51 \%$ \\
\hline
\end{tabular}

costs, for the Commodity section fabricated materials, inedible, which will maintain the status quo modal split as VWD regulations affect the trucking industry.

\section{Table 6.8 FMI Annual Railway Cost Reductions (\%) Weight-out Commodities}

\begin{tabular}{|c|c|c|c|c|c|c|c|c|c|c|}
\hline $\mathrm{O}: \backslash \mathrm{D}:$ & Ifld ${ }^{*}$ & P.E.I.* & N.S. & N.B. & Que. & Ont. & Man. & Sask. & Alta & B.C. \\
\hline Nifld * & & 1.3 & 1.3 & 1.3 & 1.3 & 1.3 & 3.0 & 3.0 & 3.0 & 3.0 \\
\hline P.E.I.* & 1.3 & & 1.3 & 1.3 & 1.3 & 1.3 & 5.8 & 5.8 & 5.8 & 5.8 \\
\hline N.S. & 1.3 & 1.3 & & 1.3 & 1.3 & 1.3 & 3.0 & 3.0 & 3.0 & 3.0 \\
\hline N.B. & 1.3 & 1.3 & 1.3 & & 0.8 & 0.8 & 1.1 & 1.9 & 1.9 & 1.9 \\
\hline Que. & 1.3 & 1.3 & 1.3 & 0.8 & & 1.4 & 1.1 & 1.9 & 1.9 & 1.9 \\
\hline Ont. & 1.3 & 1.3 & 1.3 & 0.8 & 1.4 & & 1.1 & 2.0 & 2.0 & 2.0 \\
\hline Man. & 3.0 & 5.8 & 3.0 & 1.1 & 1.1 & 1.1 & & 2.2 & 2.2 & 2.2 \\
\hline Sask. & 3.0 & 5.8 & 3.0 & 1.9 & 1.9 & 2.0 & 2.2 & & 2.2 & 2.2 \\
\hline Alta & 3.0 & 5.8 & 3.0 & 1.9 & 1.9 & 2.0 & 2.2 & 2.2 & & 2.2 \\
\hline B.C. & 3.0 & 5.8 & 3.0 & 1.9 & 1.9 & 2.0 & 2.2 & 2.2 & 2.2 & \\
\hline
\end{tabular}

National Agreement

Western Agreement

* No local rail service.

The other way for the railways to compete with lower trucking user costs is with faster door-to-door travel times. Table 6.9 contains the annual percentage reductions in door-to-door travel times that would maintain the present modal split in the face of the lower trucking user costs expected from VWD reform.

Railway competitive response will likely take the form of some combination of 
Table 6.9 FMI Competing Railway Service Improvements Cube-out Commodities

\begin{tabular}{lcc}
\hline Movements: & $\begin{array}{c}\text { Annual Railway Reductions } \\
\text { User Cost. }\end{array}$ & $\begin{array}{c}\text { Travel Time } \\
\text { Interprovincial movements among the west- }\end{array}$ \\
ern provinces & $2.96 \%$ & $1.51 \%$ \\
Shipments between Ontario and Quebec & $1.26 \%$ & $0.64 \%$ \\
Shipments to/from P.E.I. & $1.41 \%$ & $0.72 \%$ \\
All other interprovincial links & $1.71 \%$ & $0.87 \%$ \\
\hline
\end{tabular}

Table 6.10 FMI Annual Railway Travel Time Reductions (\%) Weight-out Commodities

\begin{tabular}{lrrrrrrrrrr}
\hline O: \ D: Nfld & P.E.I. & N.S. & N.B. & Que. & Ont. & Man. & Sask. & Alta & B.C. \\
\hline Nfld & & 0.6 & 0.6 & 0.6 & 0.6 & 0.6 & 1.5 & 1.5 & 1.5 & 1.5 \\
P.E.I.* & 0.6 & & 0.6 & 0.6 & 0.6 & 0.6 & 3.0 & 3.0 & 3.0 & 3.0 \\
N.S. & 0.6 & 0.6 & & 0.6 & 0.6 & 0.6 & 1.5 & 1.5 & 1.5 & 1.5 \\
N.B. & 0.6 & 0.6 & 0.6 & & 0.4 & 0.4 & 0.6 & 0.9 & 0.9 & 0.9 \\
Que. & 0.6 & 0.6 & 0.6 & 0.4 & & 0.7 & 0.6 & 0.9 & 0.9 & 0.9 \\
Ont. & 0.6 & 0.6 & 0.6 & 0.4 & 0.7 & & 0.6 & 1.0 & 1.0 & 1.0 \\
Man. & 1.5 & 3.0 & 1.5 & 0.6 & 0.6 & 0.6 & & 1.0 & 1.0 & 1.0 \\
Sask. & 1.5 & 3.0 & 1.5 & 0.9 & 0.9 & 1.0 & 1.0 & & 1.0 & 1.0 \\
Alta & 1.5 & 3.0 & 1.5 & 0.9 & 0.9 & 1.0 & 1.0 & 1.0 & & 1.0 \\
B.C. & 1.5 & 3.0 & 1.5 & 0.9 & 0.9 & 1.0 & 1.0 & 1.0 & 1.0 & \\
\hline
\end{tabular}

National Agreement

Western Agreement

* No local rail service.

reduction in real cost rates and some improvement in door-to-door travel times. For example, the results show that the trucking rate reductions between British Columbia and Ontario could be countered by a $1.0 \%$ annual reduction in real (uninflated) user costs and a 0.50\% annual shortening of rail door-to-door travel times (over the ten year period). This combined action would be an alternative to reducing rail user costs by $2.0 \%$ annually or shortening rail travel times by $1.0 \%$ annually.

For cube-out commodities, using RTAC predicted trucking cost reductions percentages, the model was applied to determine the resulting railway competitive re- 
sponse, in the form of annual reductions in user costs or door-to-door travel times. This is detailed in Table 6.10.

For the commodity section EPI, Table 6.11 presents competitive percentage reductions in annual railway user costs which will maintain the status quo modal split as VWD regulations affect the trucking industry.

\section{Table 6.11 EPI Annual Railway Cost Reductions (\%) Weight-out Commodities}

\begin{tabular}{|c|c|c|c|c|c|c|c|c|c|c|}
\hline $\mathrm{O}: \backslash \mathrm{D}:$ & Nfld* & P.E.I.* & N.S. & N.B. & Que. & Ont. & Man. & Sask. & Alta & B.C. \\
\hline Nfld* & & 1.0 & 1.0 & 1.0 & 1.0 & 1.0 & 2.5 & 2.5 & 2.5 & 2.5 \\
\hline P.E.I. ${ }^{*}$ & 1.0 & & 1.0 & 1.0 & 1.0 & 1.0 & 4.8 & 4.8 & 4.8 & 4.8 \\
\hline N.S. & 1.0 & 1.0 & & 1.0 & 1.0 & 1.0 & 2.5 & 2.5 & 2.5 & 2.5 \\
\hline N.B. & 1.0 & 1.0 & 1.0 & & 0.7 & 0.7 & 0.9 & 1.5 & 1.5 & 1.5 \\
\hline Que. & 1.0 & 1.0 & 1.0 & 0.7 & & 1.2 & 0.9 & 1.5 & 1.5 & 1.5 \\
\hline Ont. & 1.0 & 1.0 & 1.0 & 0.7 & 1.2 & & 0.9 & 1.7 & 1.7 & 1.7 \\
\hline Man. & 2.5 & 4.8 & 2.5 & 0.9 & 0.9 & 0.9 & & 1.8 & 1.8 & 1.8 \\
\hline Sask. & 2.5 & 4.8 & 2.5 & 1.5 & 1.5 & 1.7 & 1.8 & & 1.8 & 1. \\
\hline Alta & 2.5 & 4.8 & 2.5 & 1.5 & 1.5 & 1.7 & 1.8 & 1.8 & & \\
\hline B.C. & 2.5 & 4.8 & 2.5 & 1.5 & 1.5 & 1.7 & 1.8 & 1.8 & 1.8 & \\
\hline
\end{tabular}

As indicated earlier, rail could also compete through its other principal service attribute, travel time. Shortening door-to-door travel times could also maintain the present freight mode split. Annual rail improvements in door-to-door travel times sufficient to compete with the reformed trucking industry in this commodity section is presented in Table 6.12. Door-to-door travel time could be achieved by advanced railway technology and/or freight handling efficiency.

Railway competitive response will likely take the form of some combination of reduction in real cost rates and some improvement in door-to-door travel times. For example, the results show that the trucking rate reductions between Ontario and Alberta could be countered by a $0.85 \%$ annual reduction in real (uninflated) user 
Table 6.12 EPI Annual Railway Travel Time Reductions (\%) Weight-out Commodities

\begin{tabular}{lrrrrrrrrrr}
\hline O: $\backslash$ D: Nfld* & P.E.I.* & N.S. & N.B. & Que. & Ont. & Man. & Sask. & Alta & B.C. \\
\hline Nfld* & & 0.7 & 0.7 & 0.7 & 0.7 & 0.7 & 1.6 & 1.6 & 1.6 & 1.6 \\
P.E.I.* & 0.7 & & 0.7 & 0.7 & 0.7 & 0.7 & 3.2 & 3.2 & 3.2 & 3.2 \\
N.S. & 0.7 & 0.7 & & 0.7 & 0.7 & 0.7 & 1.6 & 1.6 & 1.6 & 1.6 \\
N.B. & 0.7 & 0.7 & 0.7 & & 0.5 & 0.5 & 0.6 & 1.0 & 1.0 & 1.0 \\
Que. & 0.7 & 0.7 & 0.7 & 0.5 & & 0.8 & 0.6 & 1.0 & 1.0 & 1.0 \\
Ont. & 0.7 & 0.7 & 0.7 & 0.5 & 0.8 & & 0.6 & 1.1 & 1.1 & 1.1 \\
Man. & 1.6 & 3.2 & 1.6 & 0.6 & 0.6 & 0.6 & & 1.2 & 1.2 & 1.2 \\
Sask. & 1.6 & 3.2 & 1.6 & 1.0 & 1.0 & 1.1 & 1.2 & & 1.2 & 1.2 \\
Alta & 1.6 & 3.2 & 1.6 & 1.0 & 1.0 & 1.1 & 1.2 & 1.2 & & 1.2 \\
B.C. & 1.6 & 3.2 & 1.6 & 1.0 & 1.0 & 1.1 & 1.2 & 1.2 & 1.2 & \\
\hline
\end{tabular}

National Agreement

Western Agreement

* No local rail service.

costs and a $0.55 \%$ annual shortening of rail door-to-door travel times (over the ten year period). This combined action would be an alternative to reducing rail user costs by $1.70 \%$ annually or shortening rail travel times by $1.10 \%$ annually.

For cube-out commodities, the model was applied to determine the resulting railway competitive response, in the form of annual reductions in user costs or doorto-door travel times. This is detailed in Table 6.13

Table 6.13 EPI Competing Railway Service Improvements Cube-out Commodities

\begin{tabular}{lcc}
\hline & Annual Railway Reductions \\
Movements: & User Cost & Travel Time \\
\hline Interprovincial movements among the west- & $2.45 \%$ & $1.62 \%$ \\
ern provinces & & \\
Shipments between Ontario and Quebec & $1.04 \%$ & $0.69 \%$ \\
Shipments to/from P.E.I. & $1.16 \%$ & $0.77 \%$ \\
All other interprovincial links & $1.41 \%$ & $0.93 \%$ \\
\hline
\end{tabular}




\section{$6.2 .2 \diamond \quad$ Link-by-Link Rail Revenue Loss}

By applying the relationships depicted graphically in Figure 6.1, the link-bylink rail revenue as reported by Statistics Canada, and the level of trucking cost reduction predicted by RTAC, the annual percentage decrease in rail revenue has been calculated for each of the four commodity sections. The loss of gross revenue from interprovincial movements due to the predicted reductions in truck user costs (rates) is calculated to be $2.2 \%$ of FFB\&T revenue, $3.8 \%$ of CMI revenue, $3.4 \%$ of FMI revenue, and $2.7 \%$ of EPI revenue. Morover, the total VWD reform-related loss in interprovincial revenue the railways could face has been also estimated. This total gross revenue loss results from three types of events, the loss of all revenue from some links due to service termination, the loss of a percentage of the revenue due to rate reductions aimed at meeting truck competition and retaining traffic on other links, and losses in intermodal business because of greater difficulties in handling larger truck trailers.

Table 6.14 FFB\&T Link-by-Link Distribution of Interprovincial Railway Revenue Loss (\%)

\begin{tabular}{|c|c|c|c|c|c|c|c|c|c|c|c|}
\hline$D: \backslash D:$ & Nfld. & P.E.I & & N.B & Que. & Ont. & Man. & ask. & Alta & B.C. & WT \\
\hline Nfld & & - & - & - & - & - & - & - & - & - & - \\
\hline P.E.I. & - & & - & - & 0.1 & 0.9 & 0.4 & - & - & - & - \\
\hline N.S. & 0.1 & - & & - & - & - & 0.1 & 0.1 & 0.1 & 0.1 & - \\
\hline N.B. & 0.2 & - & - & & 0.5 & 0.6 & 0.5 & - & 0.1 & 0.2 & - \\
\hline Que. & 0.8 & - & 0.2 & 0.2 & & 0.3 & 0.8 & 1.0 & 3.6 & 3.5 & - \\
\hline Ont. & 1.1 & 0.4 & 4.0 & 1.5 & 7.3 & & 2.7 & 2.1 & 10.0 & 10.4 & - \\
\hline Man. & 0.1 & 1.2 & 2.3 & 0.5 & 2.2 & 0.9 & & 0.3 & 0.9 & 2.6 & - \\
\hline Sask. & 0.1 & 0.3 & 1.4 & 0.7 & 3.0 & 1.2 & 1.2 & & 0.3 & 1.0 & - \\
\hline Alta & - & 0.6 & 1.8 & 1.3 & 8.4 & 1.9 & 1.7 & 0.8 & & 6.3 & - \\
\hline B.C. & 0.3 & 0.1 & 0.2 & 0.1 & 0.6 & 0.6 & 0.1 & 0.5 & 0.8 & & - \\
\hline NWT & - & - & - & - & - & - & - & - & - & - & \\
\hline
\end{tabular}

This research predicts that for the railways to keep their market share and remain competitive with the reformed trucking fleet, they will most likely suffer a 
Table 6.15 CMI Link-by-Link Distribution of Interprovincial Railway Revenue Loss (\%)

\begin{tabular}{llllllllllllll}
\hline O: $\backslash D:$ & Nfld. P.E.I. N.S. N.B. Que. & Ont. & Man. & Sask. & Alta & B.C. NWT \\
\hline Nfld & & & - & - & - & 0.1 & - & - & - & - & - & - \\
P.E.I. & - & & - & - & - & - & - & - & - & - & - \\
N.S. & - & - & & 0.3 & 0.5 & 0.1 & - & - & - & - & - \\
N.B. & - & 0.1 & - & & 1.5 & 0.1 & - & - & - & - & - \\
Que. & - & - & 0.1 & 0.2 & & 1.0 & 0.1 & 0.3 & 0.5 & 0.1 & - \\
Ont. & - & - & 0.1 & 0.1 & 7.8 & & 1.3 & 0.3 & 2.0 & 0.5 & - \\
Man. & - & - & - & - & 0.4 & 0.6 & & 2.5 & 1.8 & 0.6 & - \\
Sask. & - & - & - & - & 0.1 & 12.3 & 2.4 & & 0.5 & 0.3 & - \\
Alta & 0.1 & - & 0.8 & 0.6 & 3.1 & 30.4 & 0.6 & 1.1 & & 1.1 & - \\
B.C. & - & - & 0.1 & 0.1 & 1.1 & 12.0 & 1.8 & 0.2 & 7.9 & & -
\end{tabular}
NWT

- less than $0.05 \%$.

Table 6.16 FMI Link-by-Link Distribution of Interprovincial Railway Revenue Loss (\%)

\begin{tabular}{lccccccccccccc}
\hline$O: \backslash D:$ & Nfld. & P.E.I. N.S. & N.B. Que. & Ont. Man. & Sask. Alta B.C. NWT \\
\hline Nfld & & - & - & - & - & 0.2 & - & - & - & - & - \\
P.E.I. & - & & - & - & - & - & - & - & - & - & - \\
N.S. & - & - & & 0.1 & 0.4 & 0.1 & - & - & 0.1 & 0.1 & - \\
N.B. & 0.1 & - & 0.1 & & 0.1 & 0.1 & - & - & - & - & - \\
Que. & 0.4 & - & 0.4 & 0.5 & & 5.3 & 0.3 & 0.3 & 1.4 & 1.4 & - \\
Ont. & 0.3 & - & 1.0 & 0.6 & 4.6 & & 1.0 & 1.4 & 7.5 & 3.6 & - \\
Man. & - & 0.1 & 0.1 & - & 0.4 & 0.9 & & 0.1 & 0.3 & 0.1 & - \\
Sask. & 0.1 & 0.1 & 0.2 & - & 1.5 & 10.3 & 0.8 & & 0.7 & 3. & - \\
Alta & 0.2 & 0.2 & 0.5 & 0.3 & 2.6 & 5.8 & 3.7 & 1.5 & & 9.2 & - \\
B.C. & 0.4 & 0.1 & 0.7 & 0.6 & 7.4 & 13.7 & 1.2 & 0.5 & 1.4 & & - \\
NWT & - & - & - & - & - & - & - & - & - & - & - & \\
\hline
\end{tabular}

loss of their total gross revenue in the order of $3.5 \%$. The reduction in railway rates however, will probably be applied to the links where the remaining revenue will still contribute to operating overhead as well as covering variable costs. If the new revenue levels of some links fail to at least cover operating costs, then the traffic in those links can be assumed to be abandoned (within government regulations). In these cases 
Table 6.17 EPI Link-by-Link Distribution

of Interprovincial Railway Revenue Loss (\%)

\begin{tabular}{|c|c|c|c|c|c|c|c|c|c|c|c|}
\hline$: \backslash D:$ & Nfld. & E.I. & N.S. & N.B. & Que. & Ont. & Man. & Sask. & Alta & B.C. & WT \\
\hline Nfld & & - & - & - & - & - & - & - & - & - & - \\
\hline P.E.I. & - & & - & - & - & - & - & - & - & - & - \\
\hline N.S. & 1.2 & - & & - & 0.1 & 0.4 & 0.6 & - & 0.4 & 0.8 & - \\
\hline N.B. & 0.2 & - & - & & 0.1 & - & - & - & - & 0.1 & - \\
\hline Que. & 1.0 & - & 0.6 & 0.3 & & 0.8 & 0.6 & 1.0 & 3.8 & 2.6 & - \\
\hline Ont. & 1.4 & - & 2.0 & 2.7 & 6.1 & & 4.6 & 8.0 & 27.8 & 18.8 & - \\
\hline Man. & - & - & - & - & 0.1 & 0.3 & & 0.2 & 0.4 & 0.4 & - \\
\hline Sask. & - & - & - & - & - & 0.1 & - & & - & - & - \\
\hline Alta & - & - & - & 0.1 & 0.4 & 0.6 & 0.2 & 0.1 & & 0.4 & - \\
\hline B.C. & - & - & 1.2 & 0.2 & 3.6 & 3.1 & 0.5 & 0.4 & 1.2 & & - \\
\hline NWT & - & - & - & - & - & - & - & - & - & - & \\
\hline
\end{tabular}

there will be a reduction in gross revenue (but not net revenue).

The third component of rail revenue loss enumerated above is loss of intermodal traffic. This loss will be due to greater difficulties in handling larger trailers. ${ }^{*}$ In this context, an assumption could reasonably be made (based on RTAC's report) that the loss of gross revenue due to this and service abandonment combined will be in the order of 2 to $3 \%$. By combining this with the revenue decline due to competition, the total gross revenue loss will be in the order of 5.5 to $6.5 \%$. Since the estimation of these losses is made up by both stochastic analysis and reasonable assumptions, it would be quite reasonable to roughly approximate the total loss in gross revenue to be in the range of 5 to $7 \%$. This level of loss is similar to the level postulated in RTAC's 1987 report. That report conveys that the railways' own estimate of their total revenue loss would fall in the range of 4 to $9 \%$.

* See Mahoney J. H. (1985) and Hutchinson, B. G. (1987) for elaboration on the Truck/Rail intermodal issue and its relation to the new VWD regulations. Hutchinson writes: "The RTAC/ CCMTA draft regulatory principles for heavy trucks pose some problems for the railway companies of Canada." He added "past increases in the weight and dimension limits of highway trailers have been made without any consedration of the impacts on intermodal rail service. Significant changes in these truck regulations have occurred every few years and this has made it very difficult for the railway companies to provide flexible, economic and competitive intermodal service." 
VWD reform affects different origin-destination pairs to different degrees, and this compounded with freight rates and volumes that also vary from link to link results in the uneven distribution of the anticipated revenue reductions. The distribution of revenue loss for the four commodity sections are presented in Tables 6.14 through 6.17. The concentration of these revenue reductions over certain distinct link subsets in some commodity sections emphasises where railway response to VWD reform must be most concentrated and effective. For example, VWD reform is anticipated to decrease rail CMI revenue by $3.8 \%$, and $56.5 \%$ of this reduction is predicted to occur over links destinated in Ontario. Similarly, trucking reform is expected to decrease rail EPI revenue by $2.7 \%$, and $71.4 \%$ of this loss is predicted to occur over links originating in Ontario. The overwhelming importance of these link subsets strongly indicates where railway improvements will be the most effective.

Competitive improvements in rail door-to-door travel time are often most difficult to achieve for links where such improvements would be the least productive. For example, for the commodity section CMI, annual travel time improvements of $2.8 \%$ over the 1990 's would effectively compete against the trucking industry under VWD reform, for shipments to Nova Scotia from the four western provinces. This effort would eliminate only $0.9 \%$ of the revenue losses expected in CMI freight due to reform. In contrast, for the same CMI section, but for freight destined to Ontario, annual rail travel time improvements between $0.8 \%$ and $1.9 \%$ (depending upon the link) would eliminate $56.5 \%$ of the anticipated decrease in interprovincial CMI revenues.

For both the RTAC-reported research and the research reported here, it should be noted that the values developed are based on the premise that, benefitting from VWD reform, the trucking industry will pass all of the cost savings predicted by RTAC on to the user in the form of lower shipping rates. 
CHAPTER 7

\section{CONCLUSIONS AND RECOMMENDATIONS}

\section{$7.1 \odot$ Conclusions}

The research and analysis of the Canadian interprovincial freight transportation industry and VWD reform, over the broad range of commodity types studied, leads to several findings and conclusions.

The railway industry is not consistent in the rates they charge customers for the carriage of freight in that they sometimes charge lower tariffs per tonne over longer distances. This inconsistency introduces difficulties in applying user cost data in modelling freight movement. The derivation of a non-linear expression for railway user costs as a function of distance facilitated the inclusion of cost data in the models developed.

In modal split terms, the competition between rail and truck in several of these commodity sections is very high, especially over short distances. However, while per kilometre costs to ship freight reduce as distances increase for both rail and truck, they reduce at a much faster rate for rail. As a result rail dominates over trucking in the movement of FFB\&T and FMI freight over medium and longer distances, 
and trucking is very competitive over shorter distances. For the Commodity section CMI, rail dominantes over all distances, while for EPI commdity section, trucking dominantes short distances and remains very competitive over longer distances.

Developing a reliable model composed of a large number of variables with a high degree of significance has been shown to be difficult. For each model developed in this research, each of the socio-economic cross-variables consists of two single variables increasing the total number of data inputs comprising each equation to twelve. Even with the large number of inputs, the models terms all, except one, exceeded $90 \%$ significance, and most were significant in excess of $99.9 \%$. Statistical measures such as the coefficient of determination, mean square errors analysis and Mallow's $C_{P}$ Statistic have proven that these models, composed of a large number of variables, are reliable and can be used for future policy analysis of the impacts of regulatory change on freight movement in Canada.

The National and Western vehicle weight and dimension agreements will affect the interprovincial movement of freight in Canada. The reforms in VWD regulations may change the growth in rail tonnage over the 1990's with greater freight volumes carried by trucking at the expense of rail freight movement. The harmonization of VWD regulations as a result of these agreements enables the trucking industry to carry loads of greater weight and dimension, over longer distances, and in fewer trips than before, resulting in lowering the trucking operating costs. As trucking translates lower costs into lower rates, shippers will be attracted to it, diverting business from rail. However, railways possess a continuum of responses ranging from lowering rates, reducing door-to-door travel time (by introducing new technology), or a combination of both that would be enough to retain all of its existing share.

In general, the National and Western VWD agreements will have a different impact on railway freight transportation according to the commodity type carried. This difference in impact is based on the nature of the commodity and mode, percentage of revenue and tonnage carried by each mode. 
The commodity section "Food, feed, beverages and tobacco" accounts for $26 \%$ and $28 \%$ of rail tonnage and revenue. The FFB\&T's model developed in this research forecasts that by lowering user costs alone, railway competition to keep its freight market share will involve annual reduction ranging between $0.3 \%$ and $1.8 \%$. However, by utilizing the other service attribute, door-to-door travel time, an annual improvement in the order of $0.6 \%$ to $2.9 \%$ is needed to keep the rail market share. The "Crude material, inedible" classification represents the largest component of the tonnage carried by rail $47 \%$ and represents only $29 \%$ of rail revenue. The model developed for this commodity section predicts that by lowering user costs alone, railway competition to maintain pre-agreement modal split will involve reductions ranging between $1.2 \%$ and $8.1 \%$ per annum. Alternatively yearly improvements in door-todoor travel time of $0.2 \%$ to $1.8 \%$ would maintain the modal split, depending on which link is considered.

The "Fabricated materials, inedible" commodity section accounts for $25 \%$ and $33 \%$ of rail tonnage and revenue. This research also discovered that the railways' captive market is about $25 \%$ of the fabricated materials freight they currently carry. Generally, $95 \%$ of the fabricated materials freight carried by trucking is subject to competition from rail, while $75 \%$ of FMI freight carried by rail is subject to competition from trucking. The largest single component of this protected market is potash, representing more than $15 \%$ of railway FMI tonnage.

More than $45 \%$ of FMI freight carried by rail is moved over just four of the 132 interprovincial links. These are: from Saskatchewan to Ontario; from Alberta to B.C.; and in both directions between Ontario and Québec. These four links fall neither among those groups of links most affected nor least affected by VWD reform. Consequently, for FMI freight, the railways are in a relatively strong position to compete with changes in the trucking industry. Railway competition with VWD reform will likely involve improvements to the two major rail service characteristics: user costs and door-to-door travel times. The FMI model forecasts that by lowering thr user 
costs, railway competition will involve reductions ranging between $0.8 \%$ and $5.8 \%$ per annum depending on which link is considered. However, the average weighted reduction in user cost is $1.74 \%$ and $99.4 \%$ of the total annual rail tonnage is carried between links having a reduction in user cost of $2.2 \%$ or less. The model also predicts that competition by reductions in door-to-door travel times would involve yearly improvements of $0.4 \%$ to $3.0 \%$. The average weighted reduction in door-to-door travel time is $0.86 \%$ and $99.4 \%$ of the total rail tonnage is carried between links with a reduction in travel time of $1.0 \%$ or less. A combination of reductions for both the rate and travel time can be used by rail inorder to keep its market share.

Commodity classification "End products, inedible" freight accounts for $2 \%$ and $10 \%$ of rail tonnage and revenue respectively. As with other commodities, railway competition with VWD reform will likely involve improvements to the two major rail service characteristics: user cost rates and door-to-door travel times. The model developed for this commodity section forecasts that by lowering user costs, railway competition will involve reductions ranging between $0.7 \%$ and $4.8 \%$ per annum depending on which link is considered. The model also predicts that competition by reductions in door-to-door travel times would involve yearly improvements of $0.5 \%$ to $3.2 \%$.

Compounding the user costs reductions reported above, for the four commodity sections, with a minimum $5 \%$ annual inflation rate forecast for Canada for the 1990's, and considering the anticipated but unknown effects on each mode of increasing labour costs and the planned Goods and Services Tax, user costs by truck or rail will most likely rise moderately throughout the 1990's. However, the improvements of the order that reported for door-to-door travel time, for these commodities, could be made possible through advances in railway technology and/or freight handling efficiency.

Generally, for all four commodity sections rail revenue will decrease, especially for those links where both truck and rail hold substantial shares of traffic. The railways however, may respond as discussed above to keep their market share by 
lowering rates and/or reducing in door-to-door travel times, or a moderate reduction in both rate and travel time. Furthermore, the railways may also choose not to react and to accept a loss in traffic to the competition on some links as a result of VWD regulatory reform. On the other hand, the railway industry will likely expend substantial effort to maintain its market share over those links where earnings are significant. The railway industry will likely make little effort to maintain traffic over poorly performing links. The abandonment of service in some areas will likely result.

To maintain the pre-agreement rail market share, any percentage reduction in FFB\& $\mathrm{T}$ trucking rates can be matched by a smaller percentage reduction in rail rates. For FMI the matching percentage rail rate reduction is less than one and a half times the percent truck rate reduction. For CMI the percentage rail rate reduction will have to be twice the percentage trucking rate reductions. EPI percentage reductions in rail rates will approximately equal competitive reductions in truck rates. If the railways industry won't respond to trucking industry reform, and if the predicted shift takes place, a loss in the order of $2.2 \%$ of FFB\&T revenue, $3.8 \%$ of CMJ revenue, $3.4 \%$ of FMI revenue and $2.7 \%$ of EPI revenue will most likely result.

The link-by-link revenues of various types of commodities shows very clearly the concentration of manufacturing in Ontario. About half of all Crude materials moved interprovincially in Canada are destined to Ontario, and half of the nation's manufactured End products transported interprovincially originate there. Therefore reduction in terminal handling time in Ontario is one of the most effective and efficient tools available to the rail industry to reduce revenue losses due to VWD reform.

The model elasticities for truck user cost and rail user cost and travel time show that for both modes user cost is of comparable importance to modal shift for commodity sections CMI, FMI and EPI (excluding FFB\&T), and that travel time is of importance comparable to truck user cost for all four commodity sections. The result is that there is opportunity for a successful rail industry response to stronger competition from trucking within these four main commodity sections. For FFB\&T 
and EPI a response involving more attractive rates, travel times or both is practical. For CMI and FMI faster service is a more reasonable response than competition through more attractive rates.

It is clear from the analytical results that the impacts of VWD regulatory reform by both the National and Western agreements will have an effect on railway revenue. This is due in particular to the fact that some $62.0 \%$ of rail interprovincial revenue is generated by CMI and FMI freight, which are the most affected. The FFB\&T and EPI commodity sections, which are least affected, compose $38.0 \%$ of rail interprovincial revenue.

The analysis presented in this research develops and supports a level of predicted losses in interprovincial rail freight revenue $(5-7 \%)$ that is within the range of revenue losses $(4-9 \%)$ provided to RTAC by the railways. RTAC was able only to present these results without supporting methodology. The methodology and analysis used to derive the results reported in this research lend credence to the RTAC report.

\section{$7.2 \diamond$ Recommendations}

The nature of the data organization, in particular the provincial origin-destination definition and the diversity of goods and materials grouped into these commodity sections, imposes certain analytical limitations on the resulting models. The aggregate form of the data provides for an approximate representation of study area freight movement, and thus for forecasting and policy analysis, these values should be interpreted carefully. Data for specifically designated commodities at the city-to-city level, if available, would provide more accurate modelling, but at present, is unavailable for railways and not readily available for trucking.

Had this available data been divided to individual items, the resulting models might be more accurate. The research could then be tailored to only represent commodities where the competition is intense. It is recommended that follow-up research using data of this kind if available in the future to investigate such a possibility. 


\section{BIBLIOGRAPHY}

Abdelwahab, W.M., and M.A. Sargious. 1990. "A Simultaneous Decision-Making Approach to Model the Demand for Freight Transportation," Engineering in Our Environment, Proceedings, Annual Conference and 1st Biennial Environmental Specialty Conference, Volume III: Transportation, Education, History, Liability. Hamilton: Canadian Society for Civil Engineering. pp. III-52-III-64.

Allen, W. Bruce. 1977. "The Demand for Freight Transportation: A Micro Approach," Transportation Research, Volume 11, pp. 9-14.

Amemiya, Takeshi. 1981. "Quantal Response Models: A Survey," Economic Literature, Volume 19, pp. 1483-1536.

Anas, Alex. 1981. "The Estimation of Multinominal Logit Models of Joint Location and Travel Mode Choice From Aggregated Data," Journal of Regional Science, Volume 21, pp. 223-242.

Anas, Alex. 1983. "Discrete Choice Theory, Information Theory and the Multinomial Logit and Gravity Models," Transportation Research, Part B: Methodological, Volume 17B, pp. 13-23.

Baumol, W.J. and H.D. Vinod. 1970. "An Inventory Theoretic Model of Freight Transportation Demand," Management Science, Vol. 16, No. 7, pp. 413-421. Boeing Commercial Airplane Company. 1974. Transpacific Air Freight Forecasts 1972-1980. Renton, WA: The Boeing Commercial Airplane Company.

Boeing Commercial Airplane Company. 1973. U.S.-Europe Econometric Forecasts of 
Trade and Air Freight to 1980. Renton, WA: The Boeing Commercial Airplane Company.

Boyer, Kenneth D. 1977. "Minimum Rate Regulation, Modal Split Sensitivities, and the Railroad Problem," Journal of Political Economy, Volume 85, pp. 493-512. Breitenbach, Robert B. 1973. "An Analysis of Freight Networks," Transportation Journal, Volume 12, pp. 54-60.

CCMTA/RTAC. 1981. Report commissioned by Committee. September.

CCMTA/RTAC. 1986. Vehicle Weight and Dimension

Canadian Transport Commission. 1976. Report on Modelling the Demand for Freight

Transport. Research Branch, \#ESAB-76-16-1, June. Study Reports. Toronto: RTAC Publications.

CN Rail. 1984. Supertrains Schedule. Montreal: CN Rail.

Carrothers, G.A.P. 1956. "An Historical Review of the Gravity and Potential Concepts of Human Interaction," Journal of the American Institute of Planners, Volume 22, pp. 94-102.

Chenery, Hollis B. 1953. "Regional Analysis" in Hollis B. Chenery, Paul Clar, and V. Cao-Pinna, "The Structure and Growth of the Italian Economy," Rome: U.S. Mutual Security Agency.

Chenery, Hollis B. 1956. "Interregional and International Input-Output Analysis" in T. Barna (ed.) The Structural Interdependence of the Economy, New York: John Wiley and Sons Inc. pp. 341-356.

Church, D.E. 1971. "Highway Share of Intercity Shipments by Manufacturers in the U.S.," Traffic Quarterly, January, 5-16.

Clayton, A. and M. Lai. 1986. "Characteristics of Large Truck-Trailer Combinations Operating on Manitoba's Primary Highways 1974-1984," Canadian Journal For Civil Engineering, Volume 13, pp. 752-760.

Clayton, Alan M. and Fred P. Nix. 1986. "Effects of Weight and Dimension regulations: Some Evidence From Canada," Washington, DC: Transportation 
Research Board 65 ${ }^{\text {th }}$ Annual Meeting, January 1986.

Council of Transportation Ministers. 1988. Interprovincial Vehicle Weights and Dimensions Requirements Approved by Ministers of Transportation. Ottawa: Council of Transportation Ministers.

Csagoly, P.F. and R.A. Dorton. 1978. Truck Weights and Bridge Design Loads in Canada, presented at the AASHTO Annual Meeting in Louisville, KY.

Daughety, A.F. 1979. "Freight Transport Demand Revisited: A Microeconomic View of Multimodal, Multicharacteristic Service Uncertainty and the Demand for Freight Transport," Transportation Research, Volume 13B, pp. 281-288.

Daganzo, Carlos. 1979. Multinomial Probit. New York: Academic Press.

Financial Post. 1983 through 1988. Canadian Markets.

Freund, R., and Little, R. 1986. "SAS System for Regression," SAS Institute Inc.

Friedlaender, Ann F., and Richard Spady. 1980. "A Derived Demand Function for Freight Transportation," Review of Economics and Statistics, Volume 62, pp. $432-441$.

Friesz, Terry L., Roger L. Tobin and Patrick T. Harker. 1983. "Predictive Intercity Freight Network Models: The State of the Art," Transportation Research, Volume 17A, \#6, pp. 409-417.

Gilbert, Jerome, Nai-Ching Sun, Amos Ilan, and Michael C. Bunamo. 1974. "The Foreign Trade Economic Model," Transportation Research Forum, Proceedings - Fifteenth Annual Meeting, San Francisco, 10-12 October 1974, Volume XV, $\# 1$.

Gilmour, Peter. 1976. "Some Policy Implications of Subjective Factors in the Modal Choice for Freight Movements," The Logistics and Transportation Review, Volume 12, \#1. pp. 39-55.

Girling, R. R. 1988. Overweight/Overdimension Trucking in Manitoba and Western Canada, Master's Thesis, Department of Civil Engineering, University of Manitoba, Winnipeg, Manitoba. 
Hall, Randolph W. 1985. "Dependence Between Shipment Size and Mode in Freight Transportation," Transportation Science, Volume 19, \#4, November, pp. 436444.

Haritos, Z. and A. Elliott. 1983. "Canadian Transportation Regulation: Trends and Issues," Transportation, Volume 12, pp. 3-20.

Harker, Patrick T. 1987. Predicting Intercity Freight Flows, VNU Science Press BV, Utrecht, Netherlands.

Hartwig, J.C. and W. E. Linton. 1974. Disaggregate Mode Choice Models of Intercity Freight Movement, Master's Thesis, Department of Transportation Engineering, Northwestern University, Evanston, Illinois.

Hashemian, H. 1981. A behavioral Mode Choice Model Comparing Air and Truck Freight Transportaion, Ph. D.'s Thesis, Department of Civil Engineering, University of California, Berkeley, California.

Heaver, T.D. and T.H. Oum. 1976. "A Statistical Analysis of the Canadian Railway Rate Structure," The Logistics and Transportation Review, Volume 12, \#5, pp. 369-387.

Heggie, I.G. 1972. Transport Engineering Economics, McGraw Hill (U.K.) Ltd.

Hensher, D.A. and L.W. Johnson. 1981. Applied Discrete-Choice Modelling. London: Croom Helm.

Hutchinson, B. G. 1987. "Truck-Rail intermodal Weight and Dimension Compatibility Issues," RTAC Annual Conference Proceedings. 1987, vol. 3.

Isard, Walter. 1951. "Interregional and Regional Input-Output Analysis: A Model of a Space Economy," Reveiw of Economics and Statistics, Vol. 33, pp. 318-328.

Isard, Walter. 1953. "Regional Commodity Balances and Interregional Commodity Flows," American Economic Review, Vol. 43, pp. 167-180.

Isard, Walter. 1960. Methods of Regional Analysis: An Introduction to Regional Science, Cambridge: M.I.T. Press.

Kanafani, A., n.d. (1983). Transportation Demand Analysis, McGraw-Hill Series in 
Transportation.

Kennedy, P. 1985. "A Gujde to Econometrics," Second Edition, MIT Press.

Kullman, B. C. 1973. "A Model of Rail/Truck Competition in the Intercity Freight Market," Studies in Railroad Operations and Economics, Volume 15, December, MIT Report No. R74-35

Kullman, B. C. 1973. A Model of Rail/Truck Competition in the Intercity Freight Market. Unpublished Ph.D. thesis, Department of Civil Engineering, M.I.T., Cambridge, MA.

Lee, Tong Hun, D.P. Lewis and J.R. Moore. 1971. "Multiregional Intersectoral Flow Analysis," Journal of Regional Science, Vol. 11, No. 1, pp. 49-56.

Leontief, Wassily Wr. 1951. The Structure of the American Economy, 1919-1939, second edition. New York: Oxford University Press.

Leontief, Wassily W. and A. Strout. 1963. "Multiregional Input-Output Analysis," in T. Barra (ed.), Structural Interdependence and Economic Development. London: St. Martin's Press, chapter 7.

Levin, Richard C. 1978. "Allocation in Surface Freight Transportation: Does Rate Regulation Matter?," The Bell Journal of Economics, Volume 9, \#1, pp. 1845.

Long, Ross Arthur Albert. 1984. Behavioral Models of Freight Mode Share in Canada. Masters of Applied Science thesis, Department of Civil Engineering, University of Toronto.

Mahoney, John. H. 1985. Intermodal Freight Transportation. Eno Foundation for Transportation Inc.

Mallen, B.E. and J.F. Pernotte. 1972. Decision Making and Attitudes of Canadian Freight and Cargo Transportation Buyers, Montréal: Sir George Williams University.

Manheim, Marvin L. 1979. Fundamentals of Transportation Systems Analysis. Cambridge, MA: MIT Press. (MIT Press series in transportation studies. 4) 
Mason, R. 1986. "Statistical Techniques in Business and Economics," Sixth Edition, Richard D. Irwin, Inc.

Mathematica. 1967. Studies of the Demand for Freight Transportation, Volume I, PB176479. Princeton.

Mathematica. 1969. Studies of the Demand for Freight Transportation, Volume III, Part I. Princeton.

Miklius, W. 1969. "Estimating Freight Traffic of Competing Transportation Modes: An Application of the Linear Discriminant Function," Land Economics, May, pp. $267-273$.

Morton, Alexander Lyall. 1972. "Intermodal Competition for the Intercity Transport of Manufacturers," Land Economics, Volume XXXXVII, pp. 357-366.

Murthy, A.S. Narasimha and B. Ashtakala. 1987. "Modal Split Analysis Using Logit Models," Journal of Transportation Engineering, Volume 113, \#5, pp. 502519.

Neter, J., Wasserman, W., and Kutner, M. 1985 "Applied Linear Statistical Models", Second Edition, Richard D. Irwin, Inc.

Nix, F.P. 1987. Vehicle Weight and Dimension Regulations and Canada's Trucking Industry: Final Report, prepared for the Transportation Development Centre, Transport Canada.

Nix, F.P. 1988. Impact of RTAC Regulations on Trucking in Canada, presented to the Transportation Research Board, Washington, D.C.

Nix F.P. and R. Schipizky. 1984. The Effect of Vehicle Weight and Dimension Regulations, presented at the CITE Annual Conference, Ottawa, Ontario. "Derived Demand for Freight Transportation and Intermodal

Olsson, G. 1955. "Distance and Human Interaction: A Review and Bibliography," Bibliography Series No. 2, Regional Science Research Institute, Philadelphia. Oum, T.H. 1977. "Derived Demand For Freight Transportation and Intermodal Substitutabilities in Canada," Transportation Research Forum Conference Pro- 
ceedings, Volume 18, \#1, pp. 56-67. Reprinted in Journal of Transport Economics and policy,(January 1979).

Oum, Tae Hoon. 1979a. "A Warning on the Use of Linear Logit Models in Transportation Mode Choice Studies," The Bell Journal of Economics, Volume 10, \#1, pp. 374-388.

Oum, Tae Hoon. 1979b. "A Cross Sectional Study of Freight Transport Demand and Rail-Truck Competition in Canada," The Bell Journal of Economics, Volume 10, \#2, pp. 463-482.

Oum, T.H. 1979C. "Derived Demand For Freight Transportation and Inter-model competition in Canada," Journal of Transport Economics and policy, Volume 13, pp. 149-168; also in Transportation Research Forum Conference Proceedings, Volume 18, \#1, pp. 56-67.

Oum, T.H. 1980. Demand for Freight Transportation with a Special Emphasis on Mode Choice in Canada. Vancouver: Centre for Transportation Studies, University of British Columbia.

Perle, Eugene. 1964. The Demand for Transportation: Regional and Community Studies in the United States. Chicago: Department of Geography, Univeristy of Chicago.

Pearson, J.R. 1989. "Medium Combination Vehicle Use in Canada," Transportation Planning and Technology, Volume 14, pp. 125-135.

Polenske, K.R. 1966. Case Study of Transportation Models Used in Multiregional Analysis, unpublished Ph.D. dissertation, Harvard University.

Polenske, K.R. 1967. "The Study of Transportation Requirements Using National and Multiregional Input-Output Techniques," Harvard Economic Research Project, PB 174 742. Cambridge.

Quandt, Richard E. and William J. Baumol. 1966. "The Demand for Abstract Transport Modes: Theory and Measurement," Journal of Regional Science, Volume 6 , \#2, pp. 13-26. 
Rakowski, James P. 1973. "Potential Sources of Railway Freight Traffic," ICC Practitioners' Journal, Volume XXXX, pp. 576-580.

Rakowski, J.P. 1976. "Competition Between Railroads and Trucks," Traffic Quarterly, April, pp. 285-301.

Riefler, R. and C.M. Tiebout. 1970. "Interregional Input-Output: An Empirical California-Washington Model," Journal of Regional Science, Vol. 10, No. 2, pp. $135-152$.

Rigaux, L.R. 1971. "Market Share Analysis Applied to Canadian Wheat Exports," Canadian journal of Agricultural Economics, Volume 19, \#1, pp. 22-34.

Roberts et al. Development of a Policy Sensitive Model for Forecasting Freight Demand: Phase 1 Report, CTS Report No. 77-11. Cambridge, MA: M.I.T.

Roberts, P.O. and K. Wang. 1979. Predicting Freight Transport Level of Service Attributes, CTS Report No. 79-17. Cambridge, MA: M.I.T.

Roth, R.D. 1977. "Approach to Measurement of Model Advantage," Transportation Research Record 637, Washington: Transportation Research Board, National Research Council.

RTAC. 1987. Economics of Truck Sizes and Weights in Canada: Final Report, Roads and Transportation Association of Canada, Ottawa, Ontario.

Sargious, M.A. and T.S.L. Tam. 1988. "Effects of Commodity Type on Shipper's Mode Choice Behavior," CSCE 1988 Annual Conference Proceedings. Calgary: Canadian Society for Civil Engineering.

Sargious, M.A. and T.S.L. Tam. 1985a. "Data Disaggregation Procedure for Calibrating a Logit Model for Intercity Goods Movement," Transportation Planning and Technology, Volume 10, pp. 165-175.

Sargious, Michel and Timmy Tam. 1985b. "Modelling Rail and Truck Freight Rates in Canada," Logistics and Transportation Review, Volume 21, \#2, pp. 173-184.

Schlotzhauer,S., and Little, R. 1987. "SAS System for Elementary Statistical Analysis , SAS Institute Inc. 
Sen, A., S. Soot, and E. Pagitsas. 1978. "The Logit Modal Split Model: Some Theoretical Considerations," Transportation Research, Vol. 12, No. 5, pp. 321324.

Sletmo, Gunnar K. 1975. "Air Freight Forecasting and Pricing," The Logistics and Transportation Review, Volume 11, \#1, pp. 7-29.

Sloss, J. 1971. "The Demand for Intercity Motor Freight Transport: A Macroeconomic Analysis," The Journal of Business, January.

Smith, P.L. 1974. "Forecasting Freight Transport Demand - The State of the Art," The Logistics and Transportation Review, Volume 10, \#4, pp. 311-326.

Soliman Affi H., Ahmed M. Gadi, David A. Wyatt, and S.M. Easa. 1989. "Vehicle Weight \& Dimension Reform and Mode Choice in Canada," CSCE Annual Conference Proceedings. 1989, Canadian Society for Civil Engineering, St. John's.

Soliman, AH, Wyatt DA, Gadi AM, and Sabounghi R, 1988. "Mathematical Modelling of End Product Commodity Mode Choice," CSCE 1 y்8 Annual Conference Proceedings, Canadian Society for Civil Engineering, Calgary, Alberta.

Canadian Society for Civil Engineering, Montréal.

Soliman, A.H., Gadi, A.M., Wyatt, D.A., 1990. "Impacts of Vehicle Weight \& Dimension Regulations on Railway Freight Transportation," CSCE Annual Conference Proceedings, 1990, Canadian

Society for Civil Engineering, Hamilton.

Soliman, A.H., Gadi, A.M., Wyatt, D.A. and Easa, S.A., 1991. "Regulatory Reform and Freight Mode Choice" Accepted for publication Transportation March 1991.

Soliman Affi H., Ahmed M. Gadi, David A. Wyatt, 1990. "Interprovincial Rail/Truck Competition in the 1990's" Accepted for publication Transportation Planning \& Technology, September 1990. 
Soliman, AH, Gadi AM, Wyatt DA, and Sabounghi R, 1990. "Modal Shift in Canadian Freight Transportation" Transportation Quarterly, Vol. 44, No. 2, April $1990(283-301)$.

Statistics Canada. 1983. For Hire Trucking Survey, Statistics Canada Publication, 53-224.

Statistics Canada. 1984 \& 1987. Trucking in Canada Statistics Canada Publication, 53-222.

Statistics Canada. 1983-1987. Railway Transport Commodity Origin and Destination Statistics, Statistics Canada Publication, 52-214.

Stenger, Alan J. and Wayne H.J. Cunningham. 1978. "Additional Insights Concerning Rail-Truck Freight Competition," Transportation Journal, Volume 17, \#4, pp. $14-24$.

Turner, R.E. 1975. Freight Mode Selection in Canada, CIGGT Report \#75-14, October.

Turner, Ronald E. 1977. "Rail and Truck Transportation in Canada," Logistics and Transportation Review, Volume 15, \#3, pp. 419-437.

Watson, Peter L., James C. Hartwig and William E. Linton. 1974. "Factors Influencing Shipping Mode Choice For Intercity Freight: A Disaggregate Approach," Transportation Research Forum Proceedings - Fifteenth Annual Meeting: Volume XV, \#1, pp. 139-144.

Wilson, F.R., B.G. Bisson and K.B. Kobia. 1986. "Factors That Determine Mode Choice in the Transportation of General Freight," Freight Transportation, Transportation Research Record 1061. pp. 26-31. Washington: Transportation Research Board, National Research Council.

Winston, C. 1981. "A Disaggregate Model of the Demand for Intercity Freight Transportation," Econometrica, Volume 49, pp. 891-1006.

Winston, Clifford. 1983. "The Demand For Freight Transportation: Models and Applications," Transportation Research, Volume 17A, \#6, pp. 419-427. 
Young, William, A.J. Richardson and R.L. Kinnear. 1982. "Modelling Inter-Urban Freight Mode Choice," Journal of Advanced Transportation, Volume 16, \#3, pp. 303-322.

Young, W., A.J. Richardson, K.W. Ogden, and A.L. Rattray, 1983. "An InterUrban Freight Mode Choice Model," Transportation Planning and Technology, Volume 8, pp. 61-81. 
$-138-$

APPENDICES 


\title{
APPENDIX 1
}

\author{
Tractor Semi-trailer \\ A-train \\ B-train \\ C-train
}

Source: CCMTA/RTAC (1987) Report 


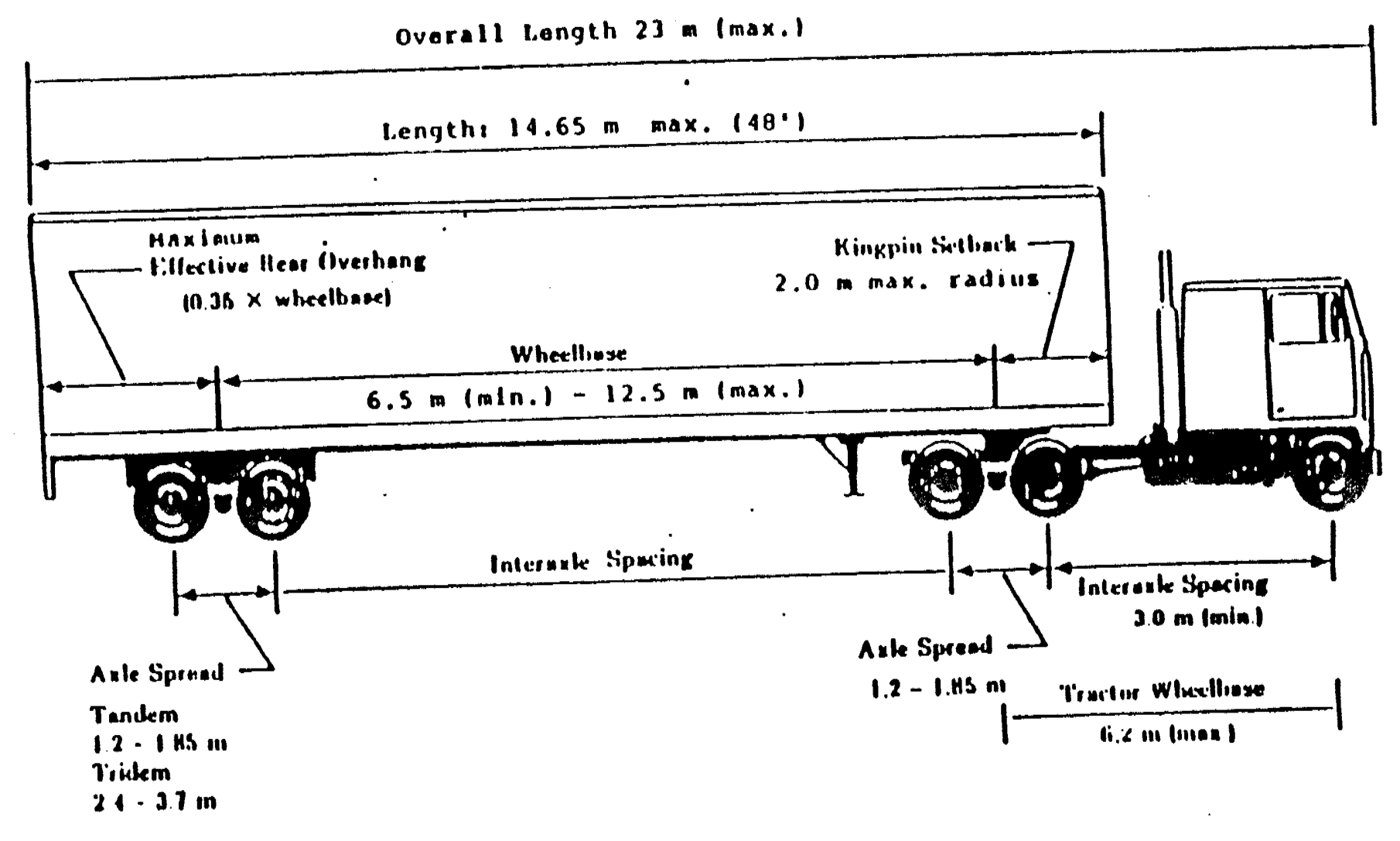

Traces Semi-trailer 
CATEGORY 1: TRACTOR SBMITRAILBR SUMMARY

Paraeter Cantrol Propoged

Proposed Linits

\section{Dnezsians}

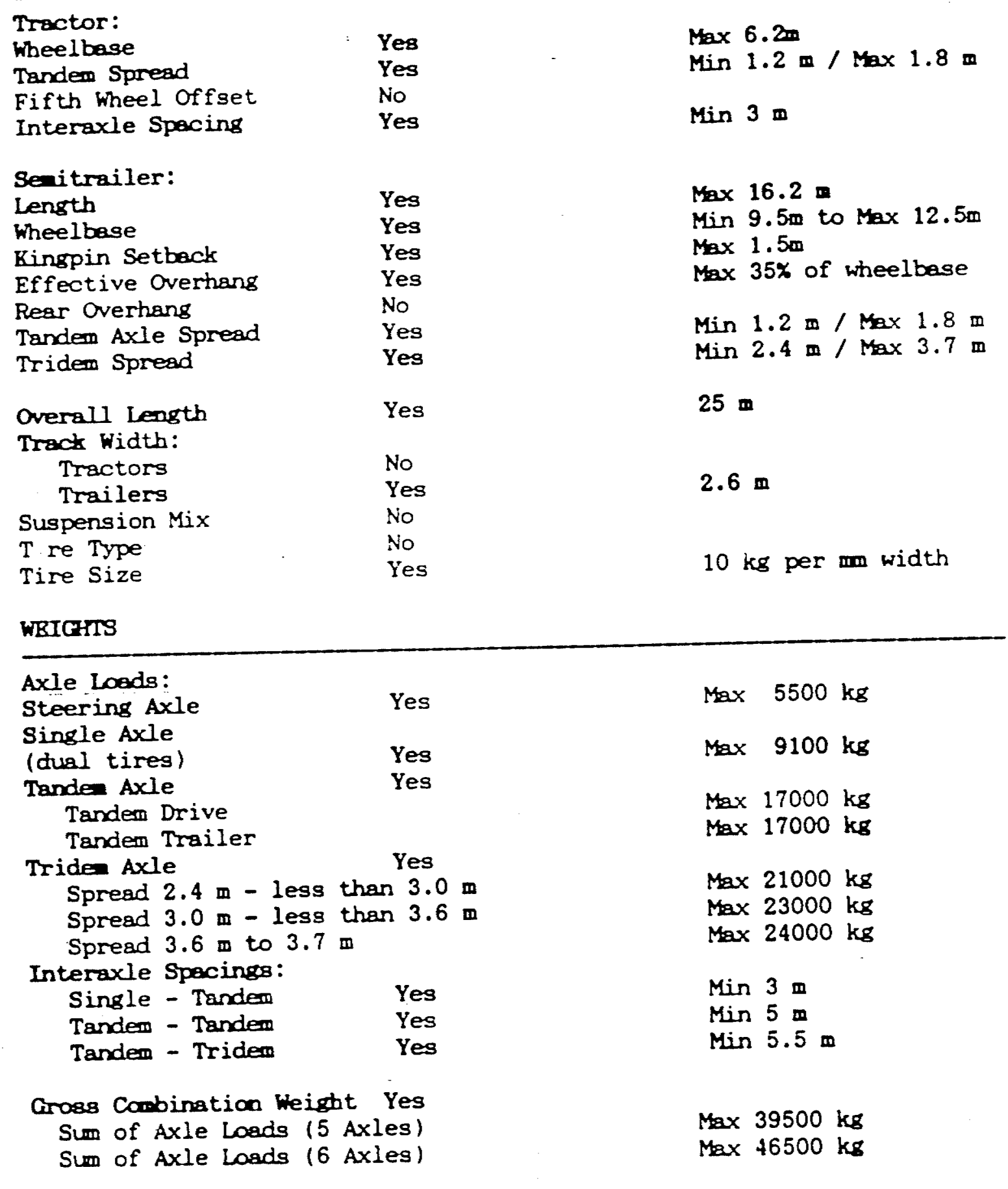




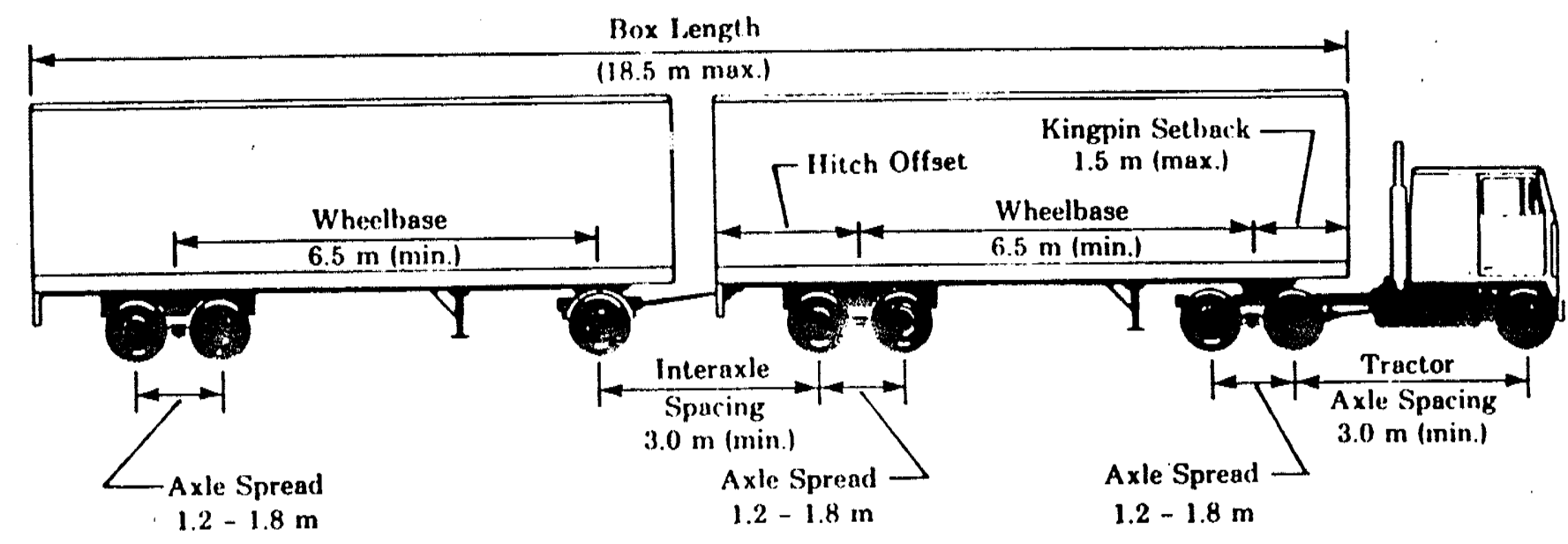

Hitch Offset

$1.8 \mathrm{~m}(\max$.

Tractor Wheelbase

$6.2 \mathrm{~m}(\max$.

\section{Drawbar Iength $2.4 \mathrm{~m}(\max$ )}

Overall I,ength $25 \mathrm{~m}$ (max.)

\section{A-Train}


CATBGORY 2: A TRANN CONPIGURATIONS

Paraneter

Control Proposed

Proposed Linita

\section{Dimsians}

\section{Tractor:}

Wheelbase

Tanden Spread

Fifth wheel offset

Interaxle Spacing

Yes

Yes

No

Yes

Pirst Senitrailer:

Length

Wheelbase

Kinspin Setback

Effective Overhans

Rear Overhang

Tandeo Axle Spread

Hitch offset

\section{No}

Yes

Yes

No

No

Yes

Yes

Secand Semitrailer:

Length

wheelbase

Kinspin Setback

Effective Overhang

Rear Overhane

Tardem Axle Spread

No

Yes

No

No

No

Yes

$\operatorname{Min} 1.2 \mathrm{~m} / \operatorname{Max} 1.8 \mathrm{~m}$

Distance from Front of Lead Trailer

to Rear of Secand Trailer Yes

Dolly:

Drawtar Length

Overall Length

Yes

Track Width:

Tractors

Trailers

Suspension Mix

Tire Type

Tire Size

Yes

No

Yes

No

No

Yes
$\operatorname{Max} 6.2=$

$\operatorname{Min} 1.2 \mathrm{~m} / \operatorname{Max} 1.8^{2} \mathrm{~m}$

Min 3

Min $6.5 \mathrm{~m}$

$\operatorname{Max} 1.5 \mathrm{~m}$

$\operatorname{Min} 1.2 \mathrm{~m} / \mathrm{Mx} 1.8 \mathrm{~m}$ $\max 1.8 \mathrm{~m}$

Min $6.5 \mathrm{~m}$

$\operatorname{Max} 18.5 \mathrm{~m}$

$\operatorname{Max} 2.4=$

$25 \mathrm{~m}$

$2.6 \mathrm{~m}$

$10 \mathrm{ks} / \mathrm{mm}$ width

\section{WEIGIS}

Axle Loads:

Steering Axle

Single Axle

Tanden Axle

Su of Axle Lads Secand Trailer

Interaxle Spacings:

Single - Single

Single - Tander

Yes

Tander - Tarden

Yes

Yes

Cross Combination Weight Yes
$\operatorname{Max} 5500 \mathrm{~kg}$

$\max 9100 \mathrm{ks}$

$\max 17000 \mathrm{ks}$

$\operatorname{Max} 16000 \mathrm{~kg}$

$\operatorname{Min} 3 \mathrm{~m}$

Min 3 m

$\operatorname{Min} 5 \mathrm{~m}$

$\operatorname{Max} 53500 \mathrm{ks}$ 


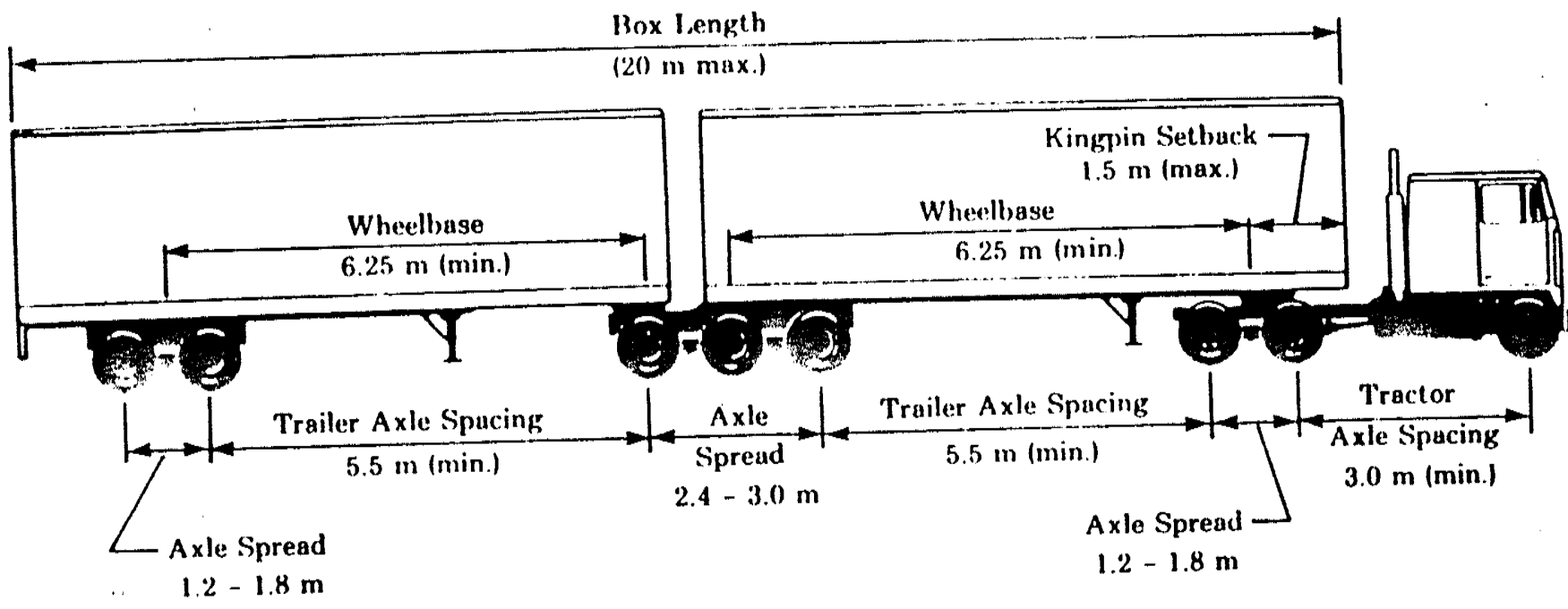

Tractor Wheclhase $6.2 \mathrm{~m}(\max$.)

Overall Iength $25 \mathrm{~m}$ (max.)

\author{
B-Train
}


CATEGORY 3: B TRAN CONFIGURATION SUMMURY

Parameter

Control Proposed.

Proposed Linits

DImasians

Tractor:

Wheelbase

Tanden Spread

Fifth wheel offset

Interaxle Spacing

Firgt Senitrailer:

Length

Wheelbase

Kingpin Setback

Tandem Axle Spread

Triden Axle Spread

Secood Senitrailer:

Length

Wheelbese

Kingpin Setback

Effective Overhang

Rear Overtang

Tandem Axle Spread

Yes

Yes

No

Yes

No

Yes

Yes

Yes

Yes

Distance fran Prant of Lead Trailer

to Rear of Second Trailer Yes

Oerall Leagth

Yes

Track Width:

Tractors

Trailers

Suspension Mix

Tire Type

Tire Size

WRICHTS

Axle Loods

Steering Axile

Single Axie

(dual tires)

Tanden Axle

Tride Axle

Spread 2.4 m to less than $3.0 \mathrm{~m}$

Spread $3.0 \mathrm{~m}$

Interaxle Spacings:

Single - Single

Single - Tandem

Tandem - Tandem

Tandem - Tridem

No

Yes

No

No

Yes
$\operatorname{Max} 6.2$

$\operatorname{Min} 1.2=/ \operatorname{Max} 1.8$.

$\operatorname{Min} 3$

$\operatorname{Min} 6.5 \mathrm{~m}$

$\operatorname{Max} 1.5 \mathrm{~m}$

$\operatorname{Min} 1.2 \mathrm{~m} / \operatorname{Max} 1.8 \mathrm{~m}$

$\max 3.0 \mathrm{~m}$

$\operatorname{Min} 6.25 \mathrm{~m}$

$\operatorname{Min} 1.2 \mathrm{~m} / \max 1.8 \mathrm{~m}$

$\operatorname{Max} 20 \mathrm{~m}$

$25 \mathrm{~m}$

$2.6 \mathrm{~m}$

$10 \mathrm{~kg}$ per min width

Gross Comination Weight Yes

Sum of Axle Laads $(7$ Axles)

Sum of Axie Loacs (8 Axiles)

$\max 5500 \mathrm{ks}$

$\operatorname{Max} 9100 \mathrm{~kg}$

$\operatorname{Max} 17000 \mathrm{~kg}$

$\max 21000 \mathrm{~kg}$

$\max 23000 \mathrm{~kg}$

$\operatorname{Min} 3$ w

Min $3 \mathrm{~m}$

Min $5 \mathrm{~m}$

$\operatorname{Min} 5.5 \mathrm{~m}$

$\max 62500 \mathrm{ks}$

$\max 56500 \mathrm{ks}$

$\max 62500 \mathrm{~kg}$ 


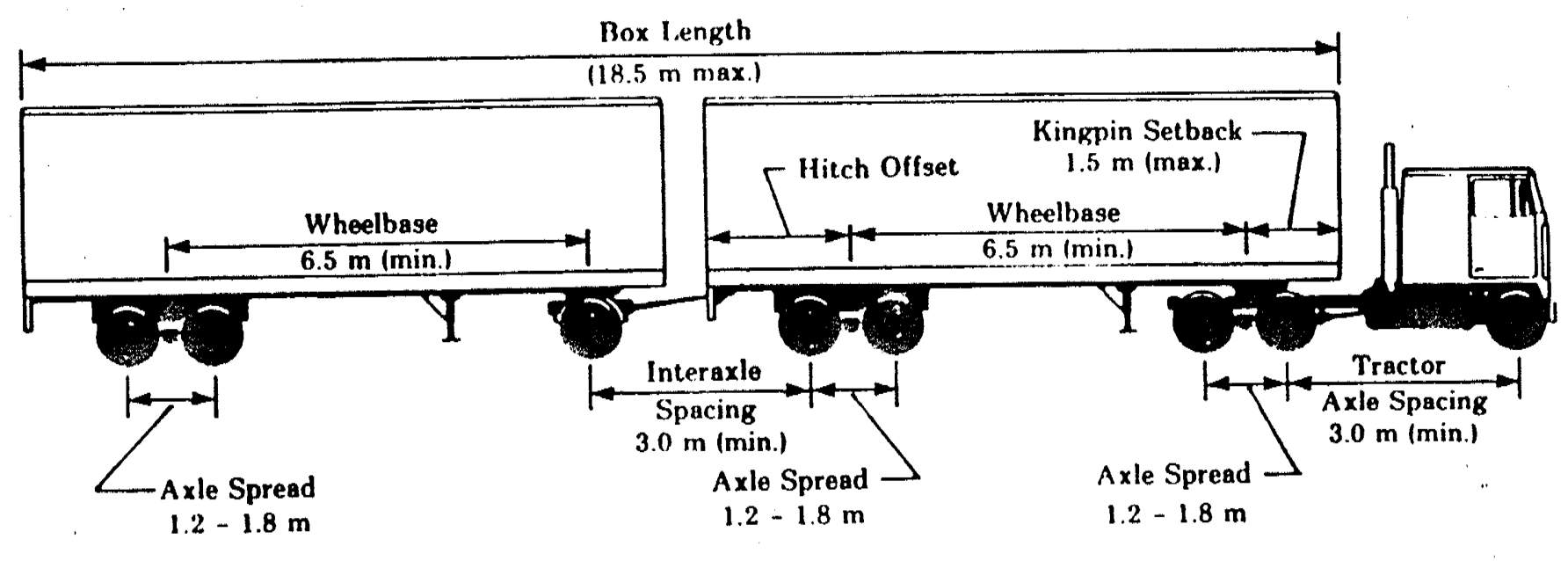

\section{Hitch Offset}

$1.8 \mathrm{~m}(\max )$

Tractor Wheelbase

$6.2 \mathrm{~m}(\max )$
Drawhar l.ength $2.4 \mathrm{~m}$ (max.)

Overall Length $25 \mathrm{~m}$ (max.)

\section{C-Train}


CATEGORY 4: C TRAIN CONFIGURATIONS

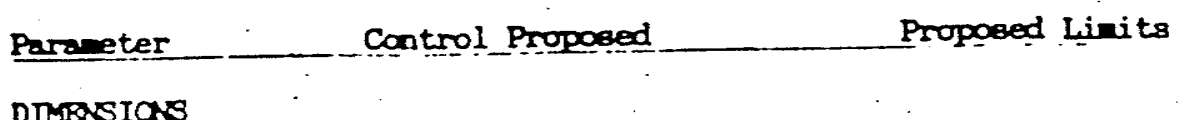

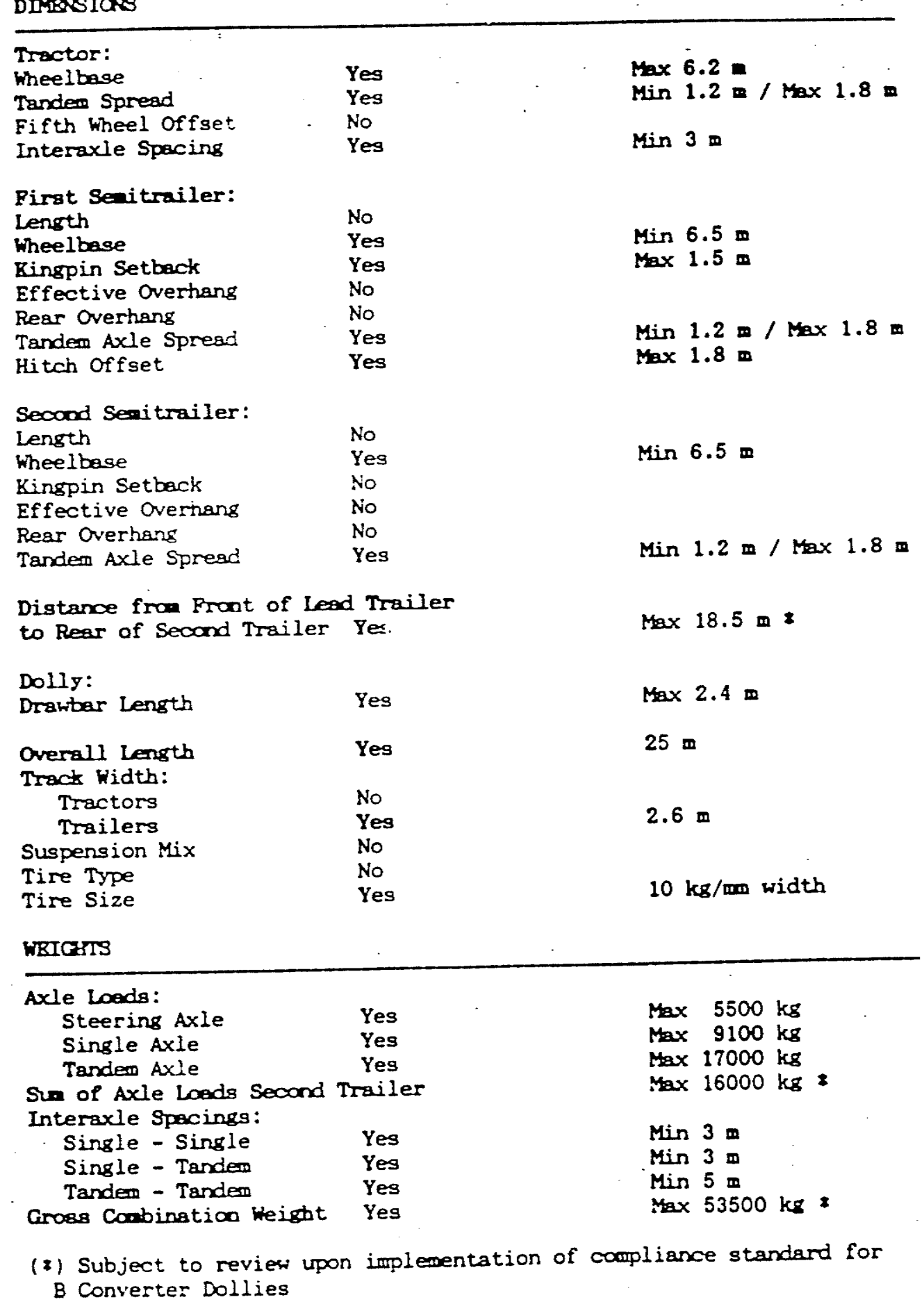


APPENDIX 2

RTAC Trucking cost reductions

for Senarios A,B,C and D

Source: RTAC 1987 Report 
EST:MEES PERCENTAGE TRUCKING COST REDUCTIONS: SCENARIO A

(a) WEIGHTTOUT COMMODITIES

\begin{tabular}{|c|c|c|c|c|c|c|c|c|c|c|}
\hline $\begin{array}{l}\text { OR:GINA } \\
\text { DESTINATIUN }\end{array}$ & $N F: O$ & PEI & NS & NB & QUE & ONT & MAN & SASK & ALTA & $B C$ \\
\hline NFLD & U & & & & & & & & & \\
\hline PE: & 5 & 5 & & & & - & & & & \\
\hline NS & 5 & 5 & 5 & & & & & & & \\
\hline NB & 5 & 5 & 5 & 0 & 0 & & & & & \\
\hline QUE & 5 & 5 & 5 & 0 & 0 & & & & & \\
\hline ONT & 5 & 5 & 5 & 0 & 0 & 0 & & & & \\
\hline MAN & 15 & 33 & 15 & 2 & 2 & 2 & 2 & & & \\
\hline SASK & 15 & 33 & 15 & 7 & 7 & 7 & 7 & 7 & & \\
\hline ALTA & 15 & 33 & 15 & 7 & 7 & 7 & 7 & 7 & 7 & \\
\hline 8.6. & 15 & 33 & 15 & 7 & 7 & 7 & 7 & 7 & 7 & $U$ \\
\hline
\end{tabular}

(O) CURE -DUT COMMODITIES

SCEVARIOA

Ont-ont, Ont-que, Que-Que To/from PE!

$12 \%$

All Otner 0-D Pairs

$15 \%$ 
ESTIMATED PERCENTAGE TRUCKING COST REDUCTIONS: SCENARIO \& \& C

(a) WEIGHT-OUT COMMODITIES

\begin{tabular}{|c|c|c|c|c|c|c|c|c|c|c|}
\hline $\begin{array}{l}\text { ORIGIN/ } \\
\text { OESTINATION }\end{array}$ & NFLO & PEI & NS & NB & QUE & ONT & MAN & SASK & ALTA & $B C$ \\
\hline NFLD & 8 & & & & & & & & & \\
\hline PEI & 13 & 13 & & & & & & & & \\
\hline NS & 13 & 13 & 13 & & & & & & & \\
\hline NB & 13 & 13 & 13 & 8 & & & & & & \\
\hline QUE & 13 & 13 & 13 & 8 & 11 & & & & & \\
\hline ONT & 13 & 13 & 13 & 8 & 11 & 0 & & & & \\
\hline MAN & 22 & 38 & 22 & 10 & 10 & 10 & 10 & & & \\
\hline SASK & 22 & 38 & 22 & 14 & 14 & 15 & 15 & 15 & & \\
\hline ALTA & 22 & 38 & 22 & 14 & 14 & 15 & 15 & 15 & 15 & \\
\hline B.C. & 22 & 38 & 22 & 14 & 14 & 15 & 15 & 15 & 15 & 0 \\
\hline
\end{tabular}

(b) CUBE-OUT COMMOOITIES

$\begin{array}{cc}\text { SCENAR:0 } 3 & \text { SCENAR:OC } \\ 9 \% & 17 \% \\ 10 \% & 18 \% \\ 12 \% & 20 \%\end{array}$

To/from PSI

All Other 0-D Pairs

105

$20 \%$ 
ESTIMATEO PERCENTAGE TRUCKING COST REDUCTIONS: SCENAR:O O

(a) WEIGHT-OUT COMOQITIES

\begin{tabular}{|l|c|c|c|c|c|c|c|c|c|c|}
\hline $\begin{array}{l}\text { ORIGIN/ } \\
\text { DESTINATION }\end{array}$ & NFLD & PEI & NS & NB & QUE & ONT & MAK & SASK & ALTA & BC \\
\hline HFLD & 6 & & & & & & & & & \\
PEI & 9 & 9 & & & & & & & & \\
NS & 9 & 9 & 9 & & & & & & & \\
NE & 9 & 9 & 9 & 6 & & & & & & \\
QUE & 9 & 9 & 9 & 6 & 6 & & & & & \\
ONT & 9 & 9 & 9 & 6 & 10 & 0 & & & & \\
MAN & 20 & 36 & 20 & 8 & 8 & 8 & 8 & & & \\
SASK & 20 & 36 & 20 & 13 & 13 & 14 & 14 & 14 & & \\
ALTA & 20 & 36 & 20 & 13 & 13 & 14 & 14 & 14 & 14 & \\
Q.C. & 20 & 36 & 20 & 13 & 13 & 14 & 14 & 14 & 14 & 0 \\
\hline
\end{tabular}

(b) CUBE-OUT COMOOITIES

SCENARIO D

ont-Ont, Ont-Que, Que-Que

TO'F rOM PEI

$10 \%$

Ali Other 0-D Pairs

$12 \%$ 


\section{APPENDIX 3}

Interprovincial Vehicle Weight and Dimensions Requirements Approved by Ministers of Transportation and its Accomplishments 


\section{INTERPROVINCIAL VEHICLE WEIGHTS AND DIMENSIONS REQUIREMENTS APPROVED BY MINISTERS OF TRANSPORTATION}

A vehicle meets the requirements of this Memorandum when all of the following conditions are meet:

1. it has all of the characteristics provided for below for the following four categories:

category 1: Tractor semitrailer

category 2: A Train Double

category 3: B Train Double

category 4: C Train Double

2. its height, including load, does not exceed 4.15 metres;

3. its width, including load but excluding mirrors, lamps, and load covering or securing devices, does not exceed 2.6 meters;

4. its length, including load, does not exceed 23 meters;

5. $\quad$ its gross combination weight does not exceed:

$46500 \mathrm{~kg}$ in the case of the Tractor Semitrailer;

$53500 \mathrm{~kg}$ in the case of the A Train Double;

$62500 \mathrm{~kg}$ in the case of the B Train Double;

$53500 \mathrm{~kg}$ in the case of the C Train Double; 
6. its axle load does not exceeded the weight limit stipulated for each axle type in its vehicle category, it being understood that the load shared between adjacent axles in a group must not vary by any more than $1000 \mathrm{~kg}$.

7. its axle load does not exceed the lesser of the maximum rated capacity of any single component of the axle, suspenion or braking system, the rated capacity of the tires, of $10 \mathrm{~kg}$ per $\mathrm{mm}$ of tire width (with a minimum tire width of $150 \mathrm{~mm}$ );

8. each semitrailer has only one axle group consisting of either a single axle cr a tandem or tridem group that will achieve equalized load sharing between axles in the group. This does not necessarily preclude the use of independently suspended axles or axle groups in the tandem or tridem categories, provided load equalization can be demonstrated.

9. its axle loads and gross Combination Weight do not exceed the limits stipulated for each axle and vehicle type, recognizing that jurisdictions will not have legislated or published tolerances concerning the enforcement of the local legislation. 


\section{VEHICLE WEIGHTS AND DIMENSIONS AGREEMENT}

\subsection{Accomplishments:}

1. Introduction of national standards for weights and dimensions which will allow the trucking industry to acquire and operate through all jurisdiction [sic] with four standard configurations of tractor trailers.

2. National acceptance of the tridem axle group, which through the research program, has shown potential to reduce pavement maintenance costs.

3. Improved uniformity of equipment at the national level, permitting trailer configurations to be constructed and used in all .jurisdiction

4. Encouragement of the use of the most stable configurations, the tractorsemitrailor [sic] and the B Train, through weight and capacity incentives.

5. Introduction, for the first time, of controls over the turning characteristics of all vehicles, recognizing the constraints of the highway geometry.

6. Introduction of controls which improve the stability of commercial vehicles, such as mandatory use of wider axles, minimum wheelbase requirements on tractors and trailers, and maximum drawbar and hitch location dimensions.

7. Establishment of an ongoing mechanisms to coordinate future changes in truck size and weight and identify areas where further research is needed to improve safety or monitor the effectiveness of regulatory practice. 


\section{APPENDIX 4}

Truck/Rail Modal Split by Commodity Section Tonnage Originated at Ontario and Transported to the Other Central and Western Provinces

For the Years 1983, 1984, 1986 and 1987

Presented in Tables 
Table A 4.1 Truck/Rail Modal Split by Commodity Section Tonnage between Ontario and Québec 1983 (\%)

\begin{tabular}{lcc}
\hline & Rail & Truck \\
\hline FFB\&T & $36 \%$ & $64 \%$ \\
CMI & $79 \%$ & $21 \%$ \\
FMI & $54 \%$ & $46 \%$ \\
EPI & $22 \%$ & $78 \%$ \\
\hline
\end{tabular}

Table A 4.2 Truck/Rail Modal Split by Commodity Section

Tonnage between Ontario and Québec 1984 (\%)

\begin{tabular}{lcc}
\hline & Rail & Truck \\
\hline FFB\&T & $33 \%$ & $67 \%$ \\
CMI & $69 \%$ & $31 \%$ \\
FMI & $55 \%$ & $45 \%$ \\
EPI & $22 \%$ & $78 \%$ \\
\hline
\end{tabular}

Table A 4.3 Truck/Rail Modal Split by Commodity Section Tonnage between Ontario and Québec 1986(\%)

\begin{tabular}{lcc}
\hline & Rail & Truck \\
\hline FFB\&T & $46 \%$ & $54 \%$ \\
CMI & $71 \%$ & $29 \%$ \\
FMI & $51 \%$ & $49 \%$ \\
EPI & $28 \%$ & $72 \%$ \\
\hline
\end{tabular}

Table A 4.4 Truck/Rail Modal Split by Commodity Section Tonnage between Ontario and Québec 1987 (\%)

\begin{tabular}{lcc}
\hline & Rail & Truck \\
\hline FFB\&T & $55 \%$ & $45 \%$ \\
CMI & $67 \%$ & $33 \%$ \\
FMI & $46 \%$ & $54 \%$ \\
EPI & $23 \%$ & $77 \%$ \\
\hline
\end{tabular}


Table A 4.5 Truck/Rail Modal Split by Commodity Section Tonnage between Ontario and Manitoba 1983 (\%)

\begin{tabular}{lcc}
\hline & Rail & Truck \\
\hline FFB\&T & $63 \%$ & $37 \%$ \\
CMI & $90 \%$ & $10 \%$ \\
FMI & $69 \%$ & $31 \%$ \\
EPI & $49 \%$ & $51 \%$ \\
\hline
\end{tabular}

Table A 4.6 Truck/Rail Modal Split by Commodity Section Tonnage between Ontario and Manitoba 1984 (\%)

\begin{tabular}{lcc}
\hline & Rail & Truck \\
\hline FFB\&T & $61 \%$ & $39 \%$ \\
CMI & $80 \%$ & $20 \%$ \\
FMI & $69 \%$ & $31 \%$ \\
EPI & $48 \%$ & $52 \%$ \\
\hline
\end{tabular}

Table A 4.7 Truck/Rail Modal Split by Commodity Section Tonnage between Ontario and Manitoba 1986 (\%)

\begin{tabular}{lcc}
\hline & Rail & Truck \\
\hline FFB\&T & $96 \%$ & $04 \%$ \\
CMI & $91 \%$ & $09 \%$ \\
FMI & $77 \%$ & $33 \%$ \\
EPI & $51 \%$ & $49 \%$ \\
\hline
\end{tabular}

Table A 4.8 Truck/Rail Modal Split by Commodity Section Tonnage between Ontario and Manitoba 1987 (\%)

\begin{tabular}{lcc}
\hline & Rail & Truck \\
\hline FFB\&T & $96 \%$ & $04 \%$ \\
CMI & $58 \%$ & $42 \%$ \\
FMI & $77 \%$ & $33 \%$ \\
EPI & $43 \%$ & $57 \%$ \\
\hline
\end{tabular}


Table A 4.9 Truck/Rail Modal Split by Commodity Section Tonnage between Ontario and Saskatchewan 1983 (\%)

\begin{tabular}{lcc}
\hline & Rail & Truck \\
\hline FFB\&T & $78 \%$ & $22 \%$ \\
CMI & $99 \%$ & $01 \%$ \\
FMI & $86 \%$ & $14 \%$ \\
EPI & $70 \%$ & $30 \%$ \\
\hline
\end{tabular}

Table A 4.10 Truck/Rail Modal Split by Commodity Section Tonnage between Ontario and Saskatchewan 1984 (\%)

\begin{tabular}{lcc}
\hline & Rail & Truck \\
\hline FFB\&T & $81 \%$ & $19 \%$ \\
CMI & $99 \%$ & $01 \%$ \\
FMI & $88 \%$ & $12 \%$ \\
EPI & $64 \%$ & $36 \%$ \\
\hline
\end{tabular}

Table A 4.11 Truck/Rail Modal Split by Commodity Section Tonnage between Ontario and Saskatchewan 1986 (\%)

\begin{tabular}{lcc}
\hline & Rail & Truck \\
\hline FFB\&T & $99 \%$ & $01 \%$ \\
CMI & $99 \%$ & $01 \%$ \\
FMI & $96 \%$ & $04 \%$ \\
EPI & $71 \%$ & $29 \%$ \\
\hline
\end{tabular}

Table A 4.12 Truck/Rail Modal Split by Commodity Section Tonnage between Ontario and Saskatchewan 1987 (\%)

\begin{tabular}{lcc}
\hline & Rail & Truck \\
\hline FFB\&T & $99 \%$ & $01 \%$ \\
CMI & $99 \%$ & $01 \%$ \\
FMI & $96 \%$ & $04 \%$ \\
EPI & $63 \%$ & $37 \%$ \\
\hline
\end{tabular}


Table A 4.13 Truck/Rail Modal Split by Commodity Section Tonnage between Ontario and Alberta 1983 (\%)

\begin{tabular}{lcc}
\hline & Rail & Truck \\
\hline FFB\&T & $69 \%$ & $31 \%$ \\
CMI & $99 \%$ & $01 \%$ \\
FMI & $83 \%$ & $17 \%$ \\
EPI & $66 \%$ & $34 \%$ \\
\hline
\end{tabular}

Table A 4.14 Truck/Rail Modal Split by Commodity Section Tonnage between Ontario and Alberta 1984 (\%)

\begin{tabular}{lcc}
\hline & Rail & Truck \\
\hline FFB\&T & $71 \%$ & $29 \%$ \\
CMI & $99 \%$ & $01 \%$ \\
FMI & $86 \%$ & $14 \%$ \\
EPI & $62 \%$ & $38 \%$ \\
\hline
\end{tabular}

Table A 4.15 Truck/Rail Modal Split by Commodity Section Tonnage between Ontario and Alberta 1986 (\%)

\begin{tabular}{lcc}
\hline & Rail & Truck \\
\hline FFB\&T & $90 \%$ & $10 \%$ \\
CMI & $99 \%$ & $01 \%$ \\
FMI & $87 \%$ & $13 \%$ \\
EPI & $65 \%$ & $35 \%$ \\
\hline
\end{tabular}

Table A 4.16 Truck/Rail Modal Split by Commodity Section Tonnage between Ontario and Alberta 1987 (\%)

\begin{tabular}{lcc}
\hline & Rail & Truck \\
\hline FFB\&T & $90 \%$ & $10 \%$ \\
CMI & $99 \%$ & $01 \%$ \\
FMI & $85 \%$ & $15 \%$ \\
EPI & $61 \%$ & $39 \%$ \\
\hline
\end{tabular}


Table A 4.17 Truck/Rail Modal Split by Commodity Section Tonnage between Ontario and British Columbia 1983 (\%)

\begin{tabular}{lcc}
\hline & Rail & Truck \\
\hline FFB\&T & $68 \%$ & $32 \%$ \\
CMI & $99 \%$ & $01 \%$ \\
FMI & $91 \%$ & $09 \%$ \\
EPI & $67 \%$ & $33 \%$ \\
\hline
\end{tabular}

Table A 4.18 Truck/Rail Modal Split by Commodity Section Tonnage between Ontario and British Columbia 1984 (\%)

\begin{tabular}{lcc}
\hline & Rail & Truck \\
\hline FFB\&T & $66 \%$ & $34 \%$ \\
CMI & $99 \%$ & $01 \%$ \\
FMI & $92 \%$ & $08 \%$ \\
EPI & $58 \%$ & $42 \%$ \\
\hline
\end{tabular}

Table A 4.19 Truck/Rail Modal Split by Commodity Section Tonnage between Ontario and British Columbia 1986 (\%)

\begin{tabular}{lcc}
\hline & Rail & Truck \\
\hline FFB\&T & $76 \%$ & $24 \%$ \\
CMI & $99 \%$ & $01 \%$ \\
FMI & $95 \%$ & $05 \%$ \\
EPI & $58 \%$ & $42 \%$ \\
\hline
\end{tabular}

Table A 4.20 Truck/Rail Modal Split by Commodity Section Tonnage between Ontario and British Columbia 1987 (\%)

\begin{tabular}{lcc}
\hline & Rail & Truck \\
\hline FFB\&T & $77 \%$ & $23 \%$ \\
CMI & $99 \%$ & $01 \%$ \\
FMI & $94 \%$ & $06 \%$ \\
EPI & $65 \%$ & $35 \%$ \\
\hline
\end{tabular}




\section{APPENDIX 5}

Example of Short, Medium and Long Haul

Truck/Rail Modal Split by Commodity Section

Tonnage Originated at Ontario and Transported

to Québec, Manitoba, Alberta and British Columbia

For the Years 1983, 1984, 1986 and 1987

Depicted in Figures 
Tornage ('000)

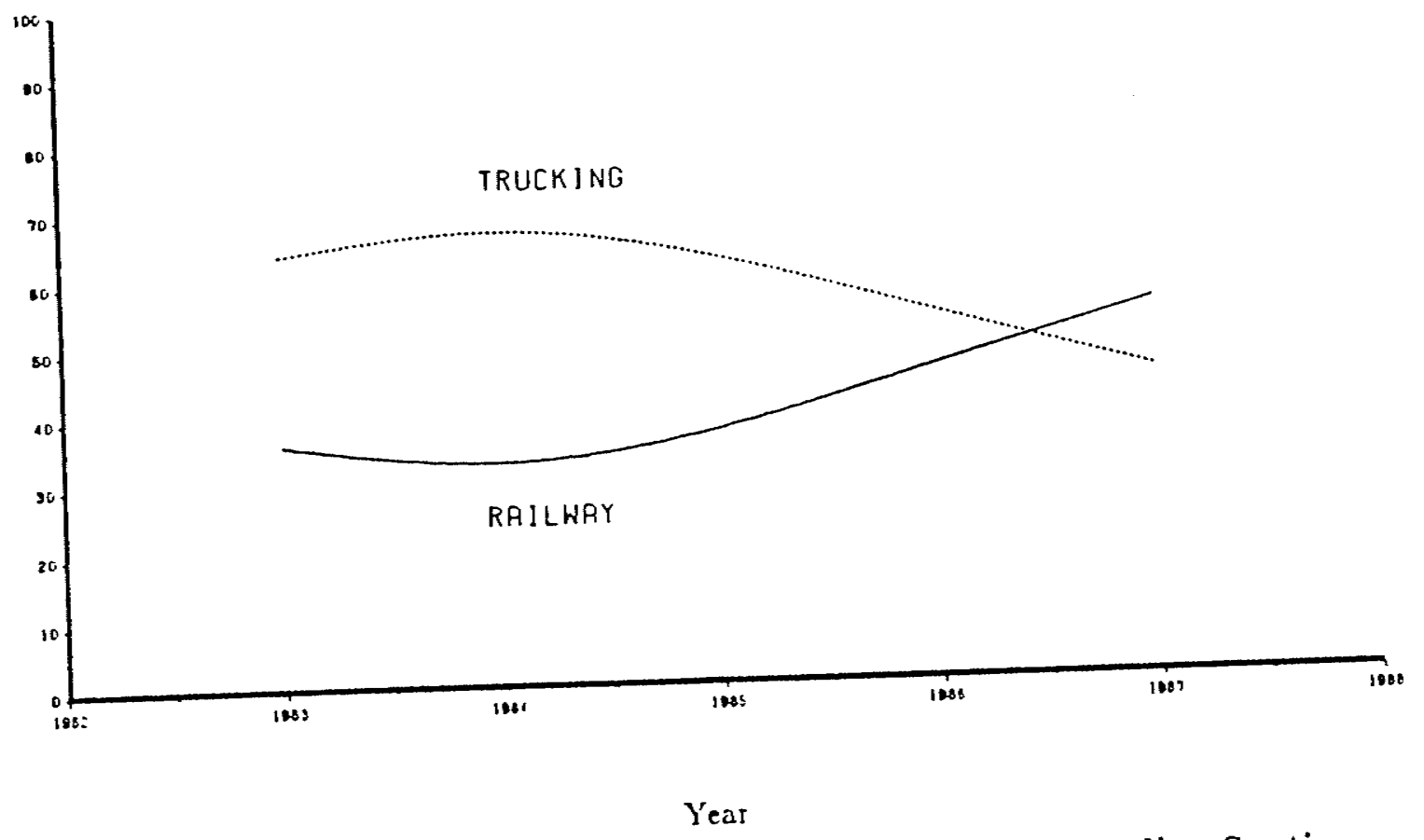

Figure A 5.1 FFB\&:T Truck/Rail Modal Split by Commodity Section Tonnage From Ontario to Québec

Tonnage ('000)

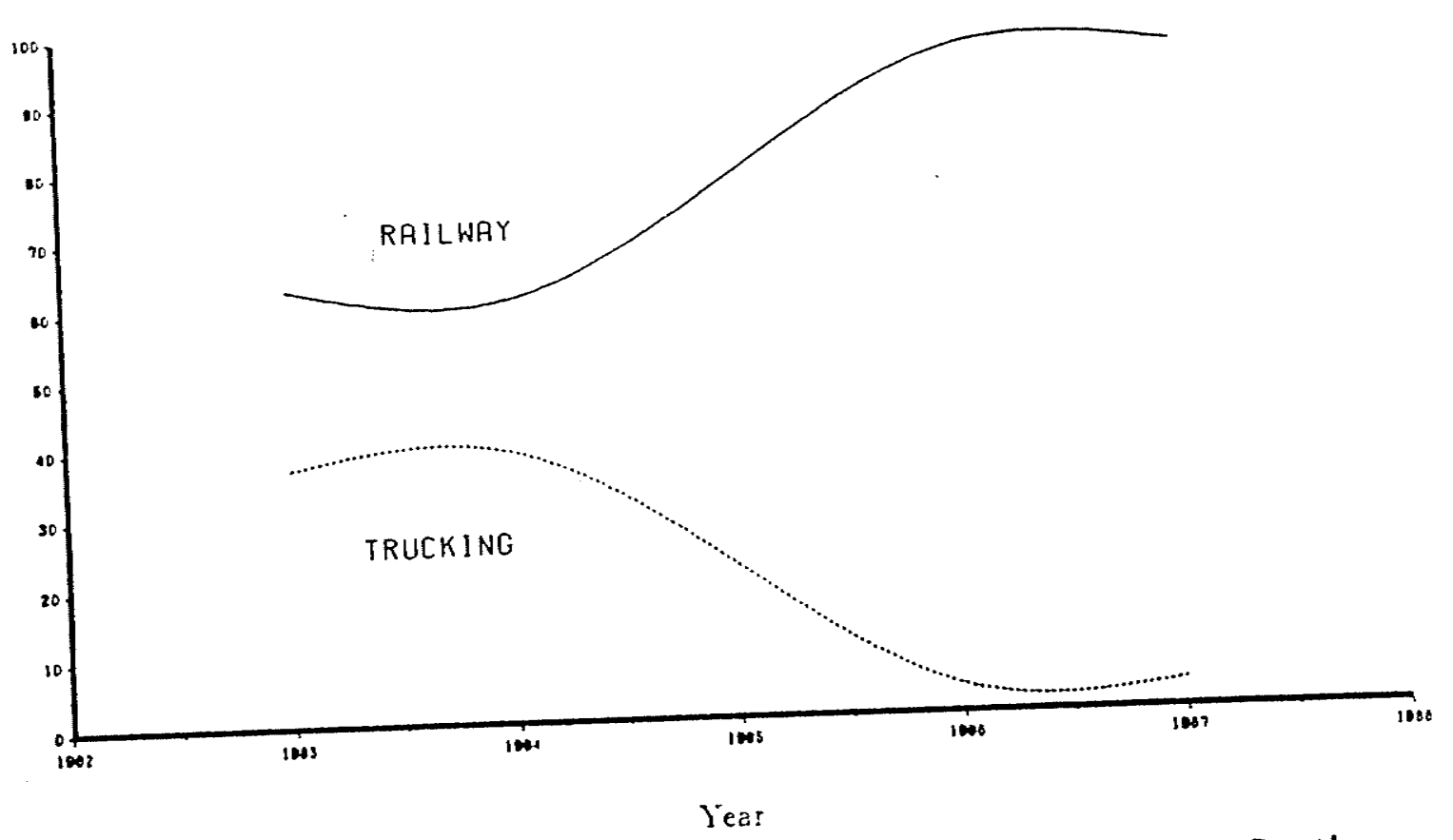

Figure A 5.2 FFB\& T Truck/Rail Modal Split by Commodity Section Tonnage From Ontario to Manitoba 
Tonnage ('000)

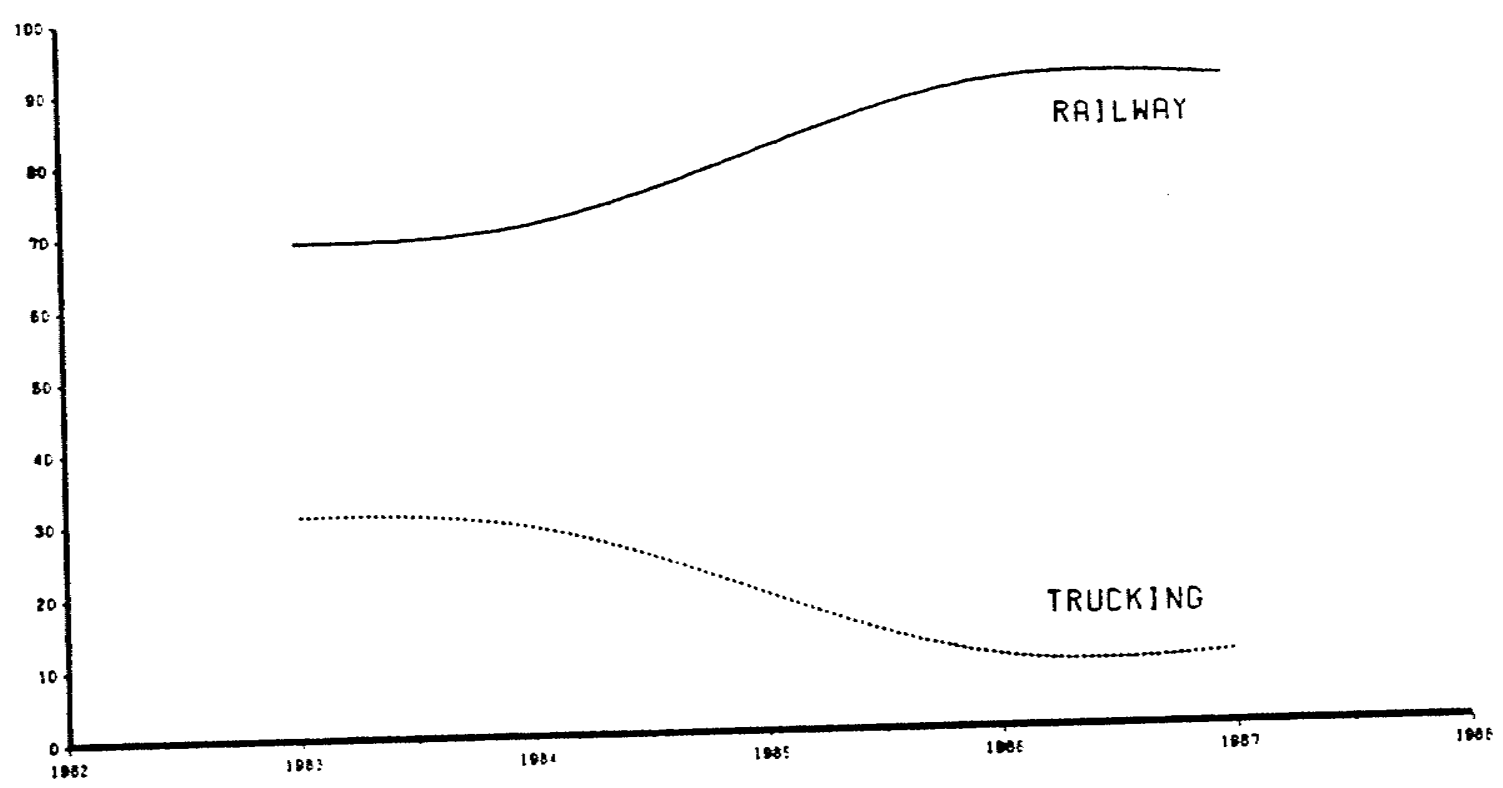

lear

Figure A j.3 FFB\&T Truck/Rail Modal Split by Commodity Section Tonnage From Ontario to Alberta

Tonnage ('000)

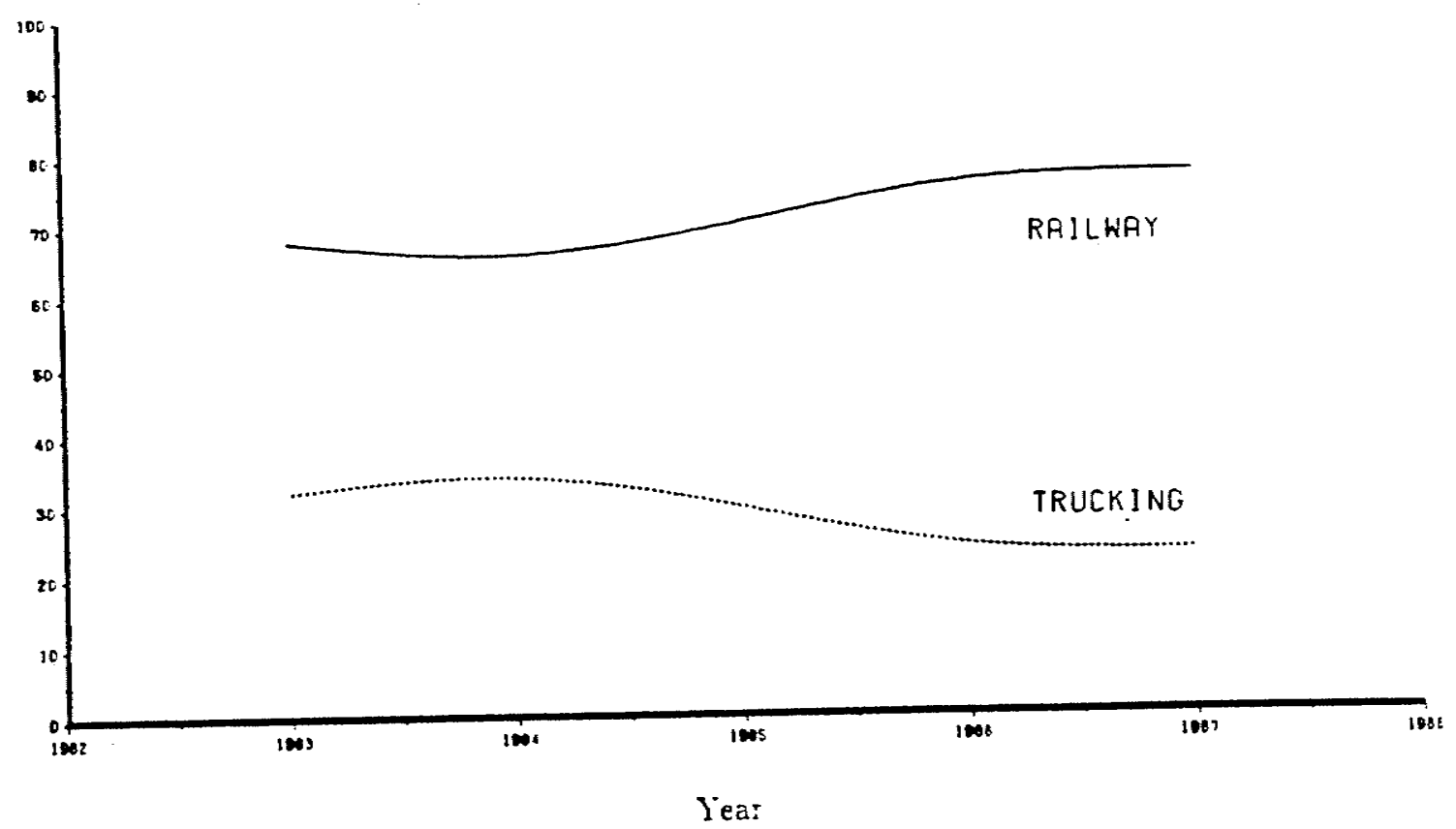

Figure A 5.4 FFB\&T Truck/Rail Modal Split by Commodity Section Tonnage From Ontario to British Columbia 
Tonnage ('000)

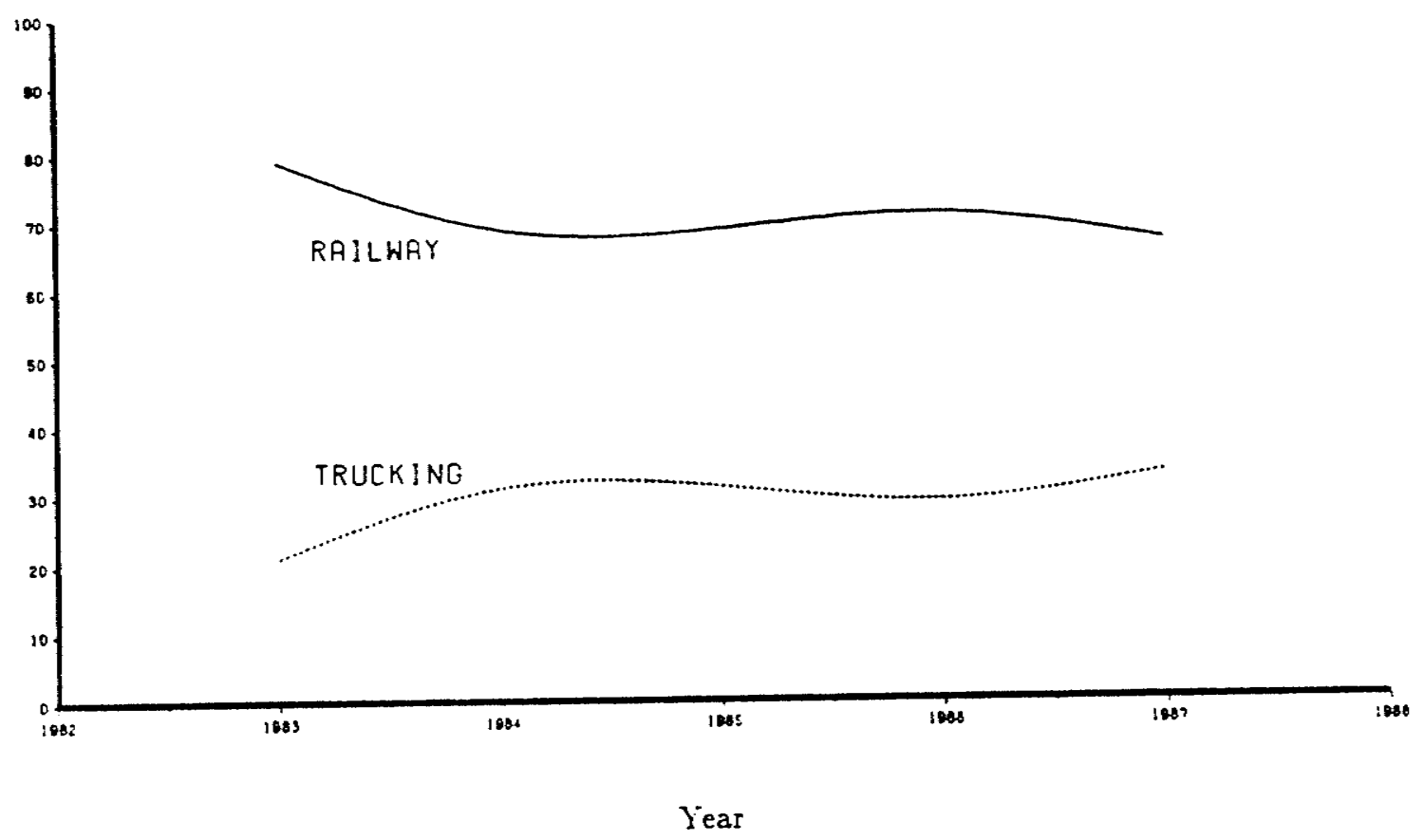

Figure A 5.5 CMI Truck/Rail Modal Split by Commodity Section Tonnage From Ontarıo to Québec

Tonnage ('000)

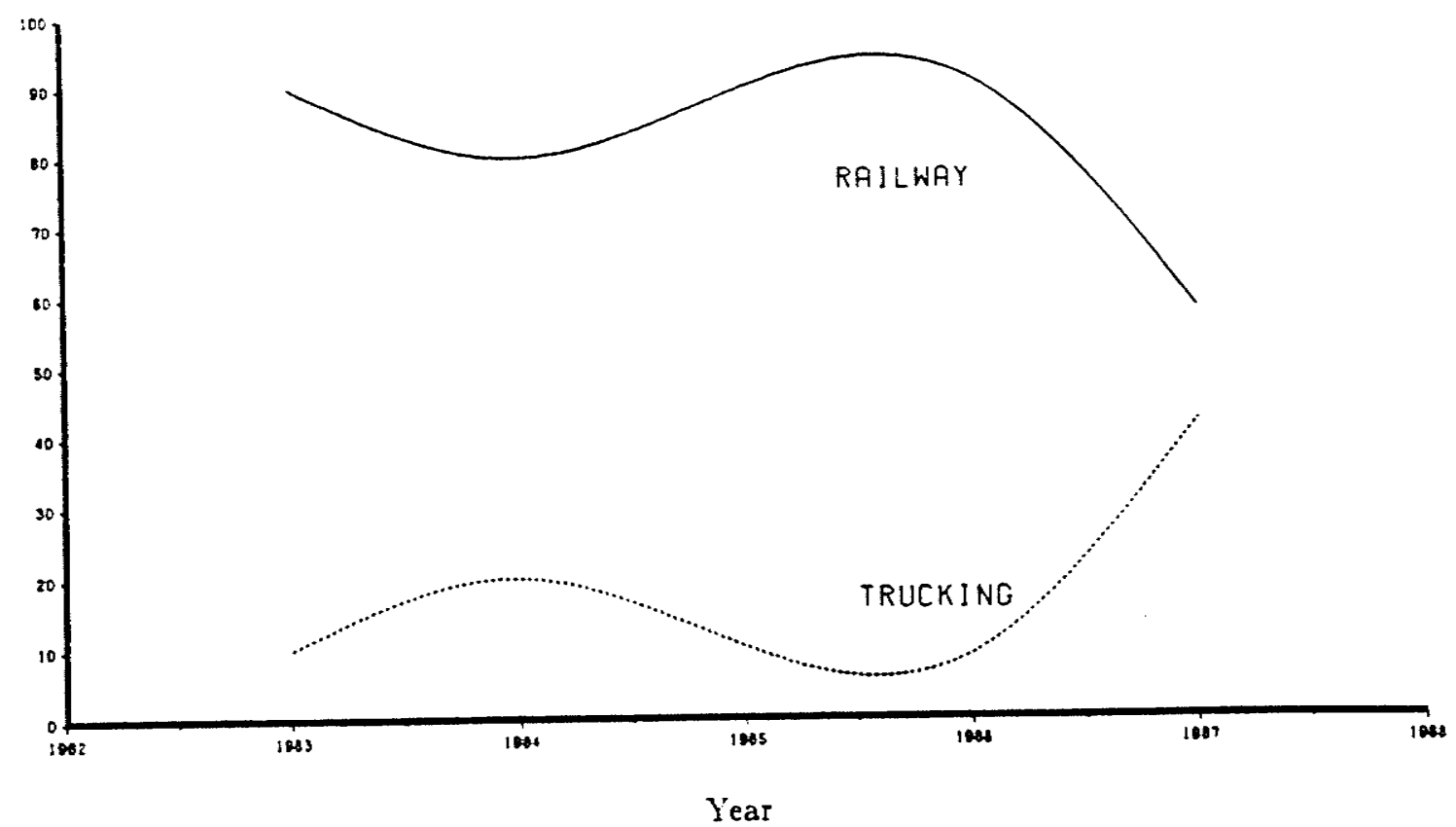

Figure A j.6 CMI Truck/Rail Modal Split by Commodity Section Tonnage From Ontario to Manitoba 
Tor.nage ('000)

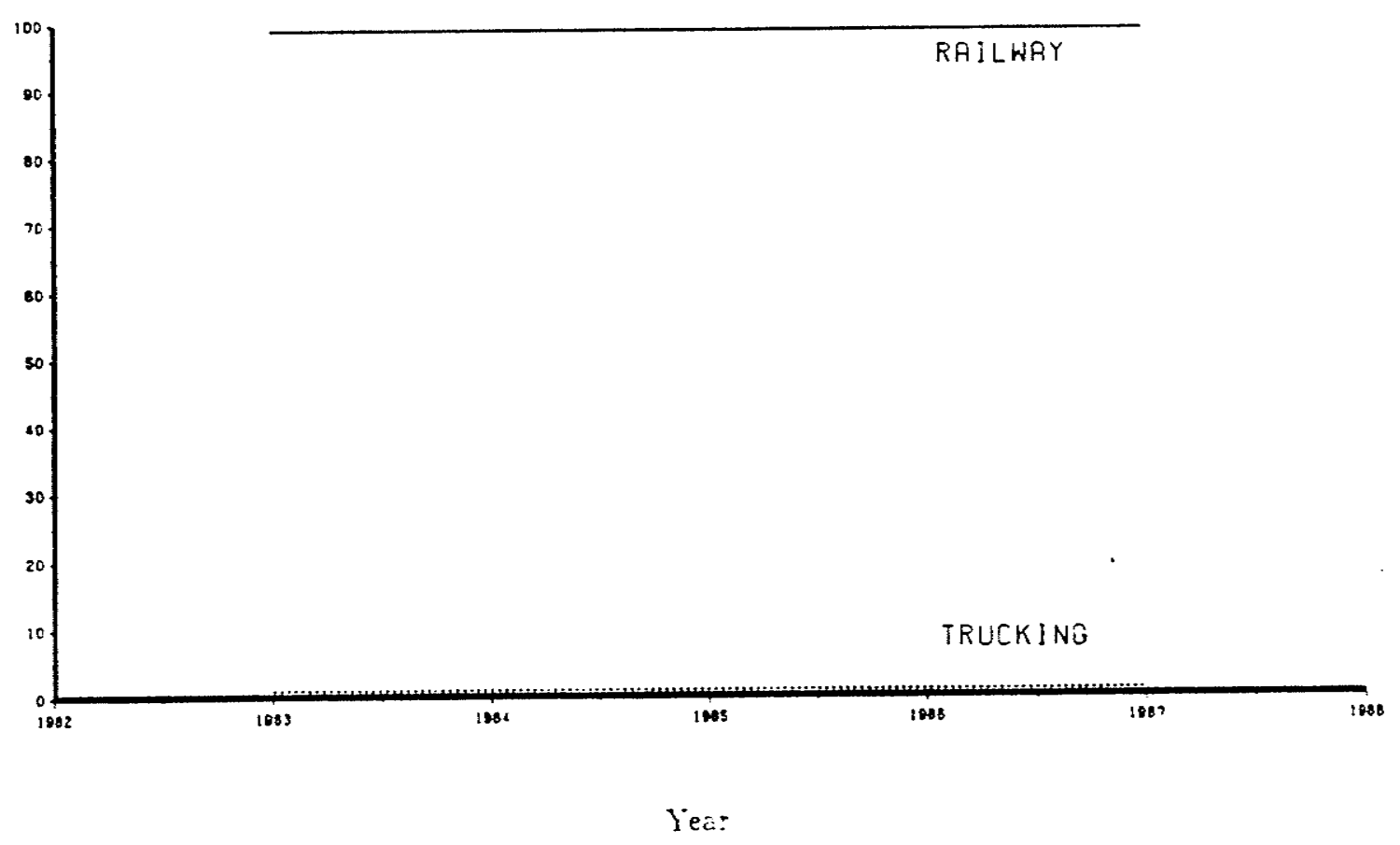

Figure A 5. - CMI Truck/Rail Modal Split by Commodity Section Tonnage From Ontario to Alberta

Tonnage ('000)

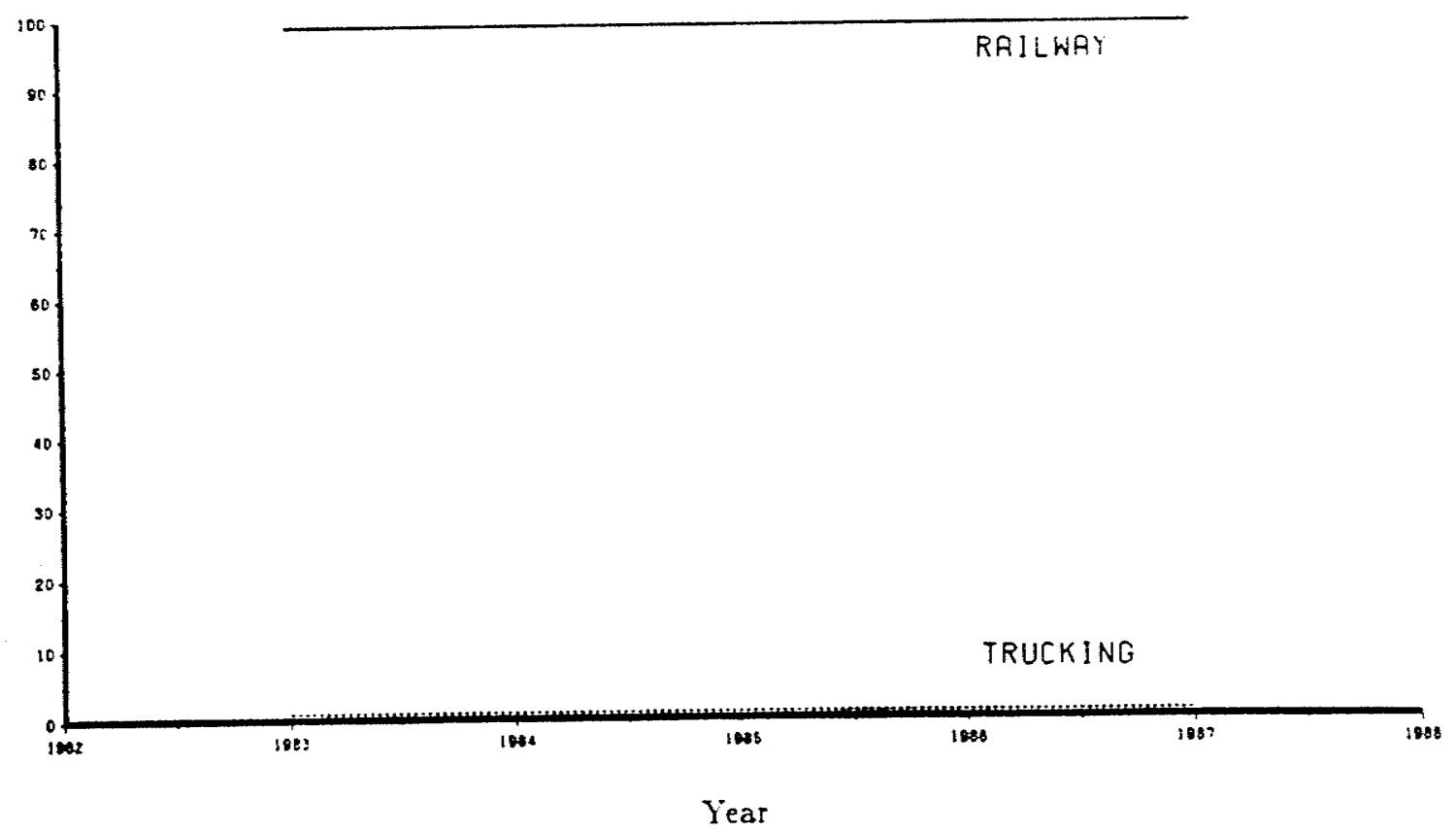

Figure A 5.8 CMI Truck/Rail Modal Split by Commodity Section Tonnage From Ontario to British Columbia 
Tonnage ('000)

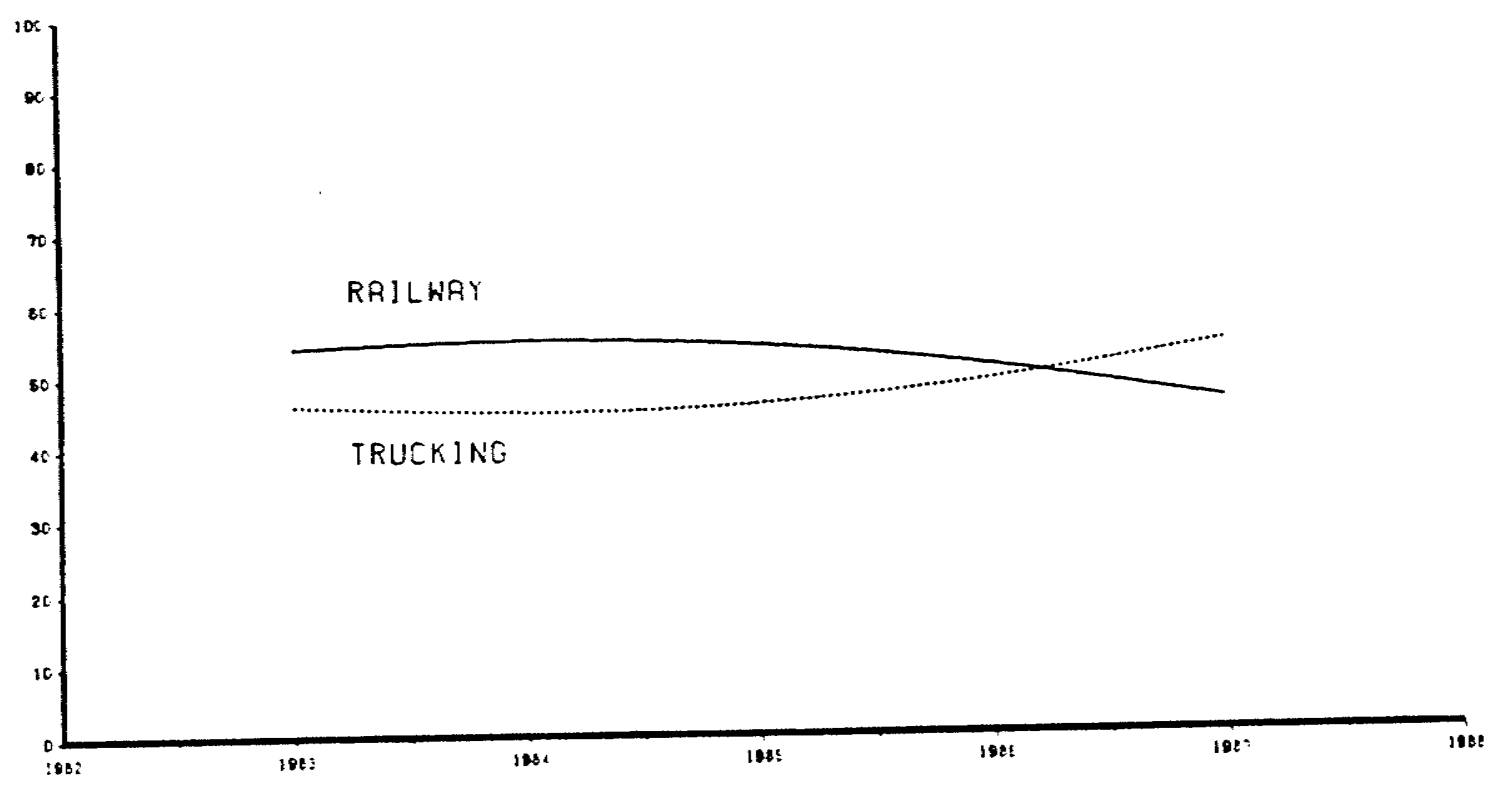

lear

Figure A 5.9 FMI Truck/Rail Modal Split by Commodity Section Tonnage From Ontario to Québec

Tonnage ('000)

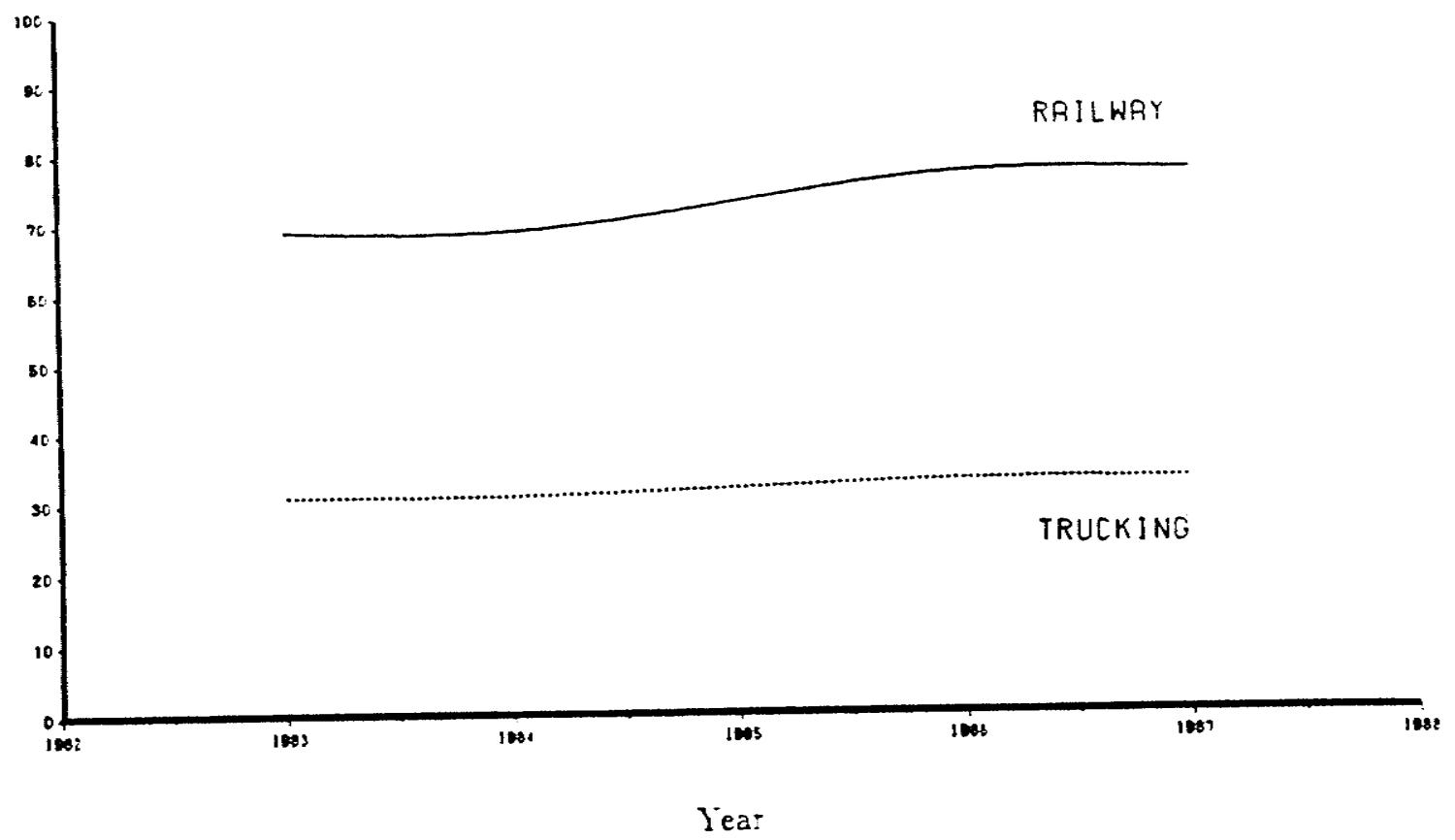

Figure A 5.10 FNII Truck/Rail Modal Split by Commodity Section Tonnage From Ontario to Manitoba 
Tonnage ('000)

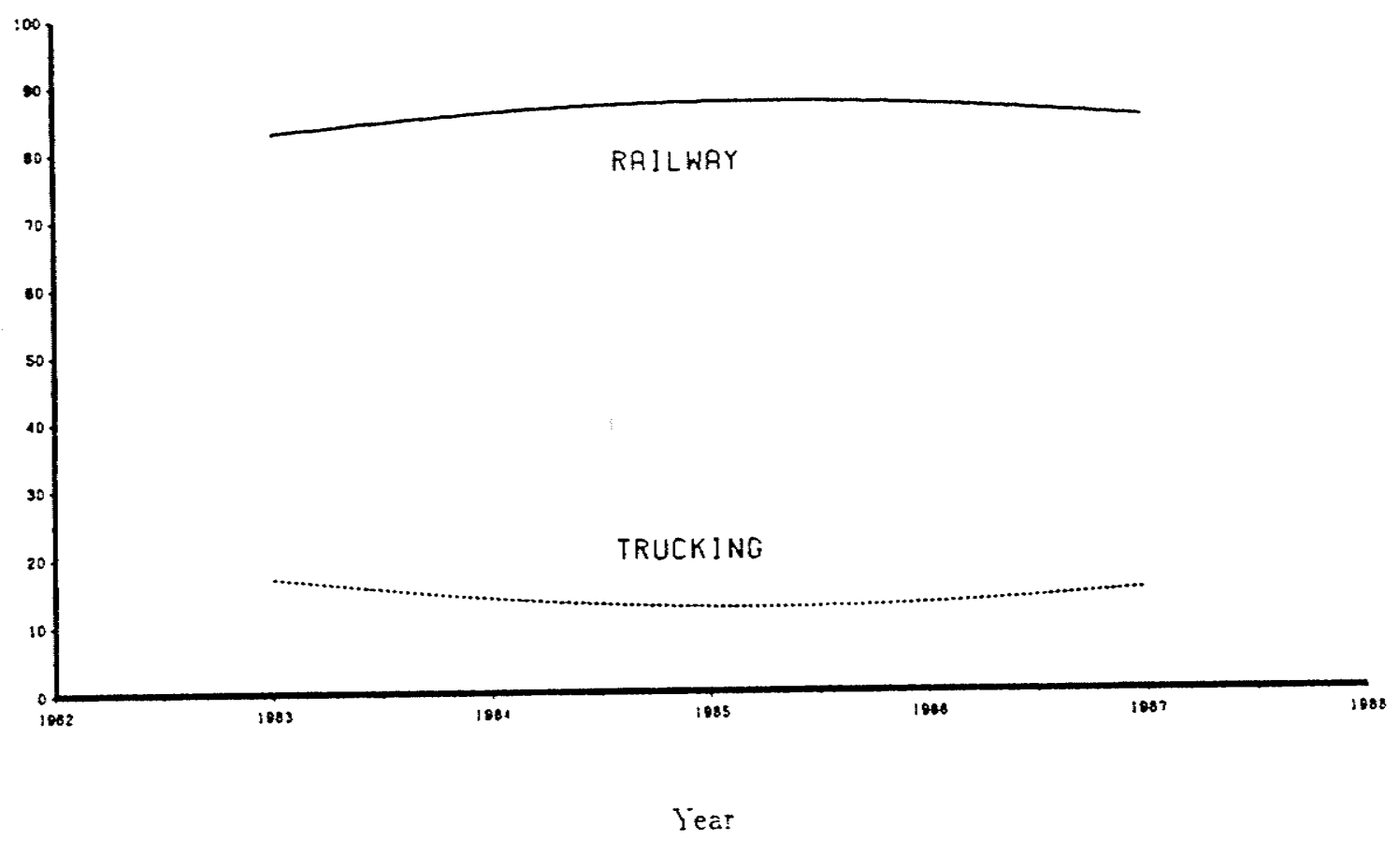

Figure A 5.11 FMI Truck/Rail Modal Split by Commodity Section Tonnage From Ontario to Alberta

Tonnage ('000)

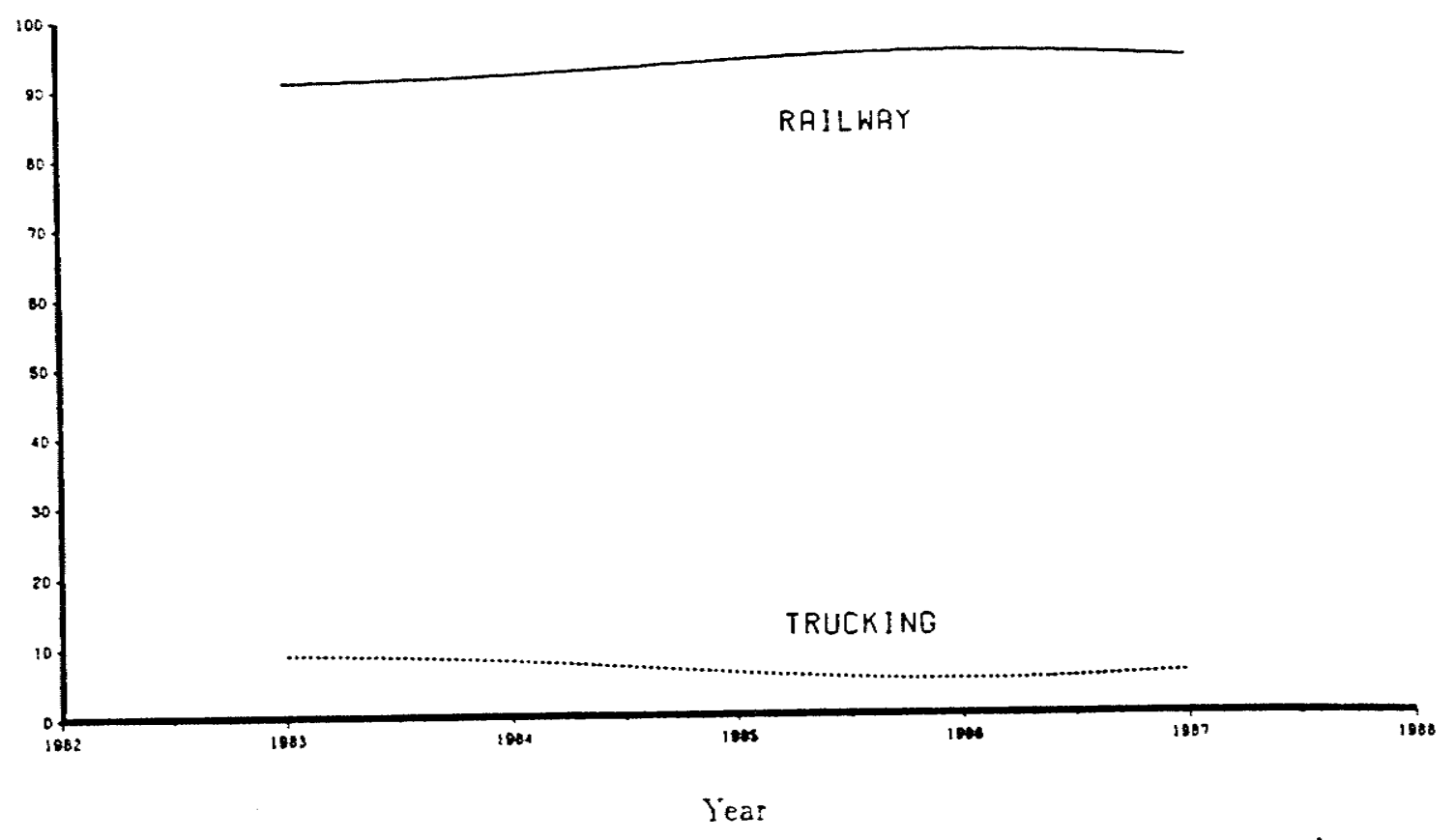

Figure A 5.12 FMI Truck/Rail Modal Split by Commodity Section Tonnage From Ontario to British Columbia 
Tonnage ('000)

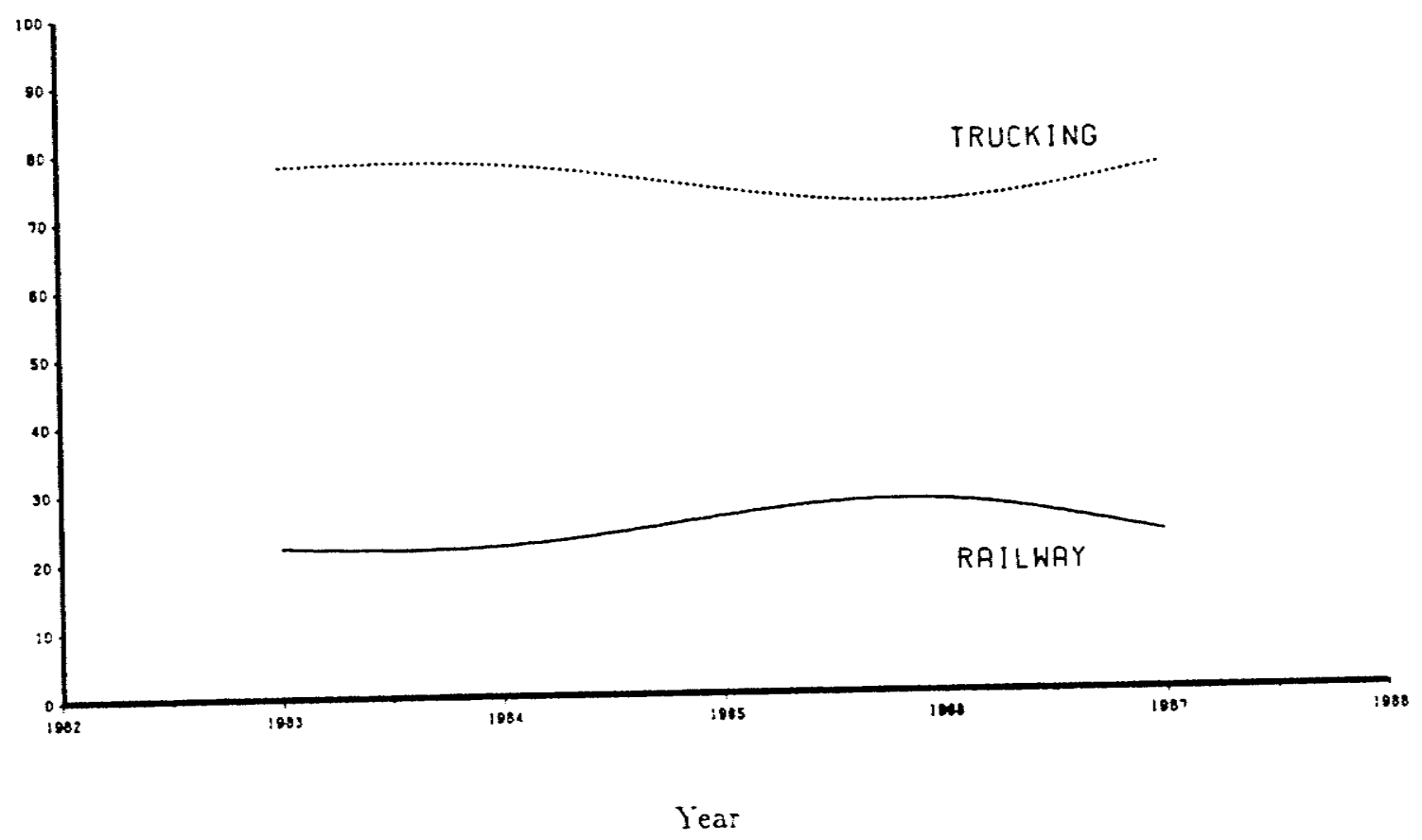

Figure A 5.13 EPI Truck/Rail Modal Split by Commodity Section Tonnage From Ontario to Québec

Tonnage ('000)

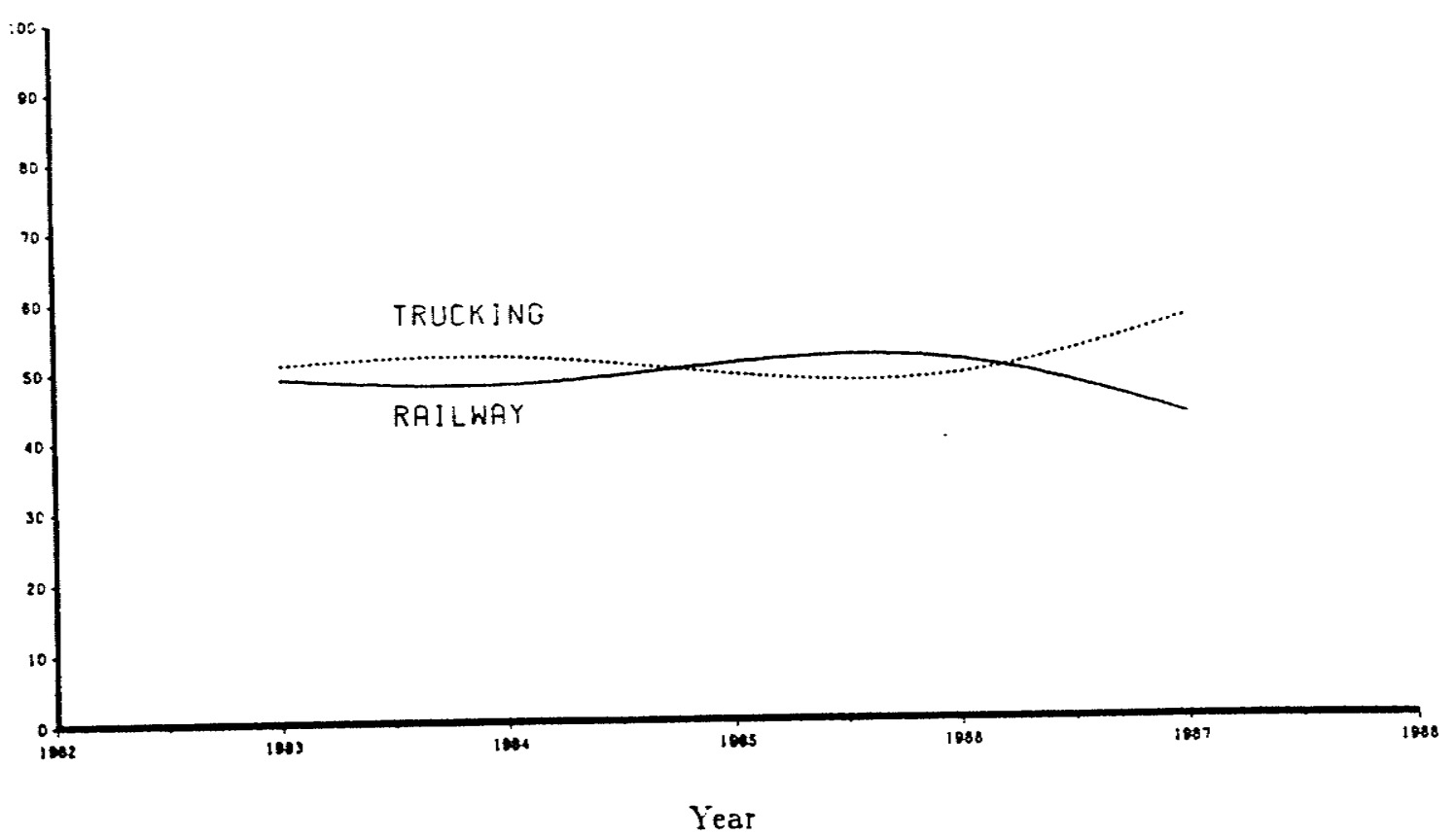

Figure A 5.14 EPI Truck/Rail Modal Split by Commodity Section Tonnage From Ontario to Manitoba 
Tonnage ('000)

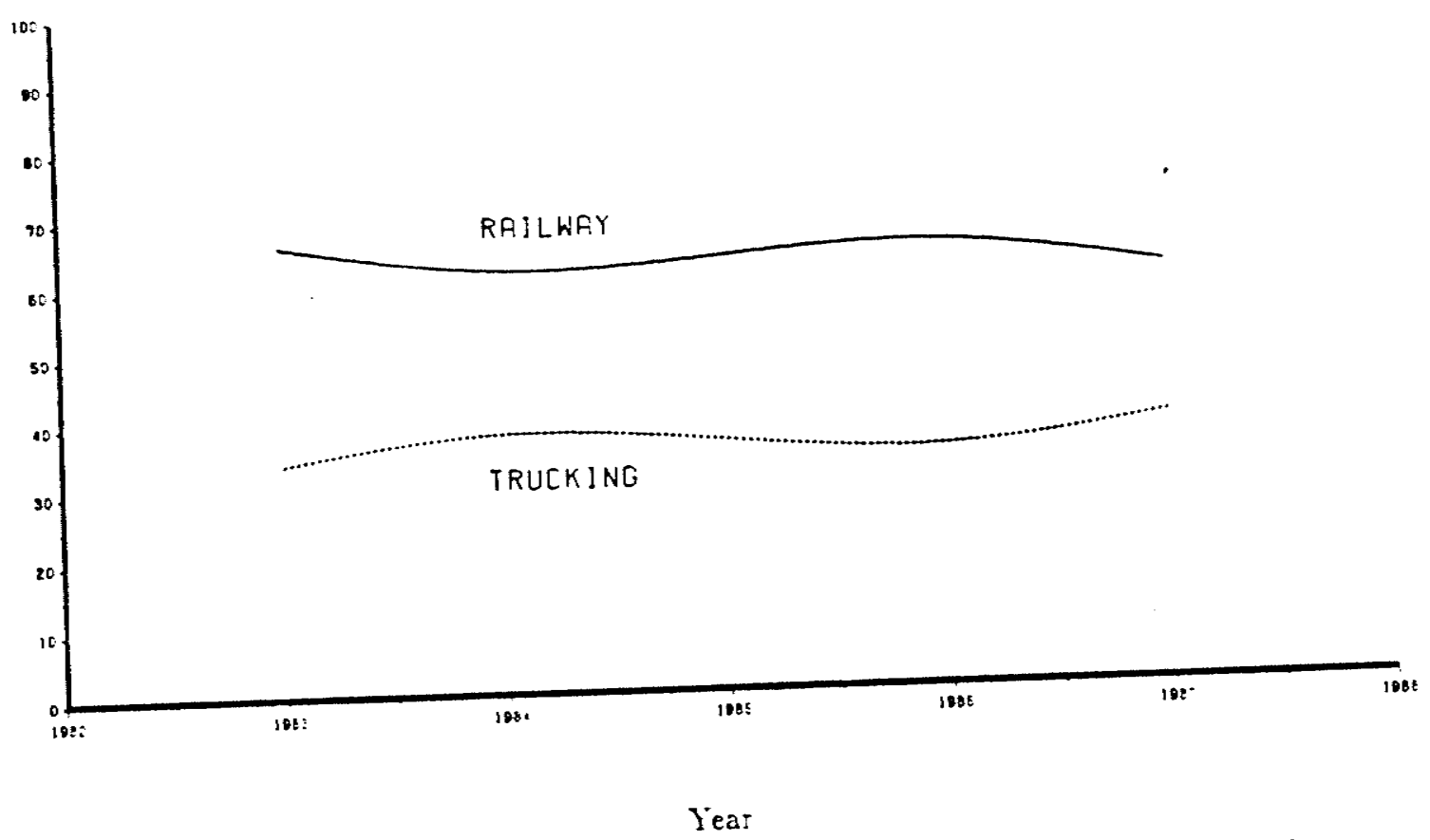

Figure A5.15 EPI Truck/Rail Modal Split by Commodity Section Tonnage From Ontario to Alberta

Tonnage ('000)

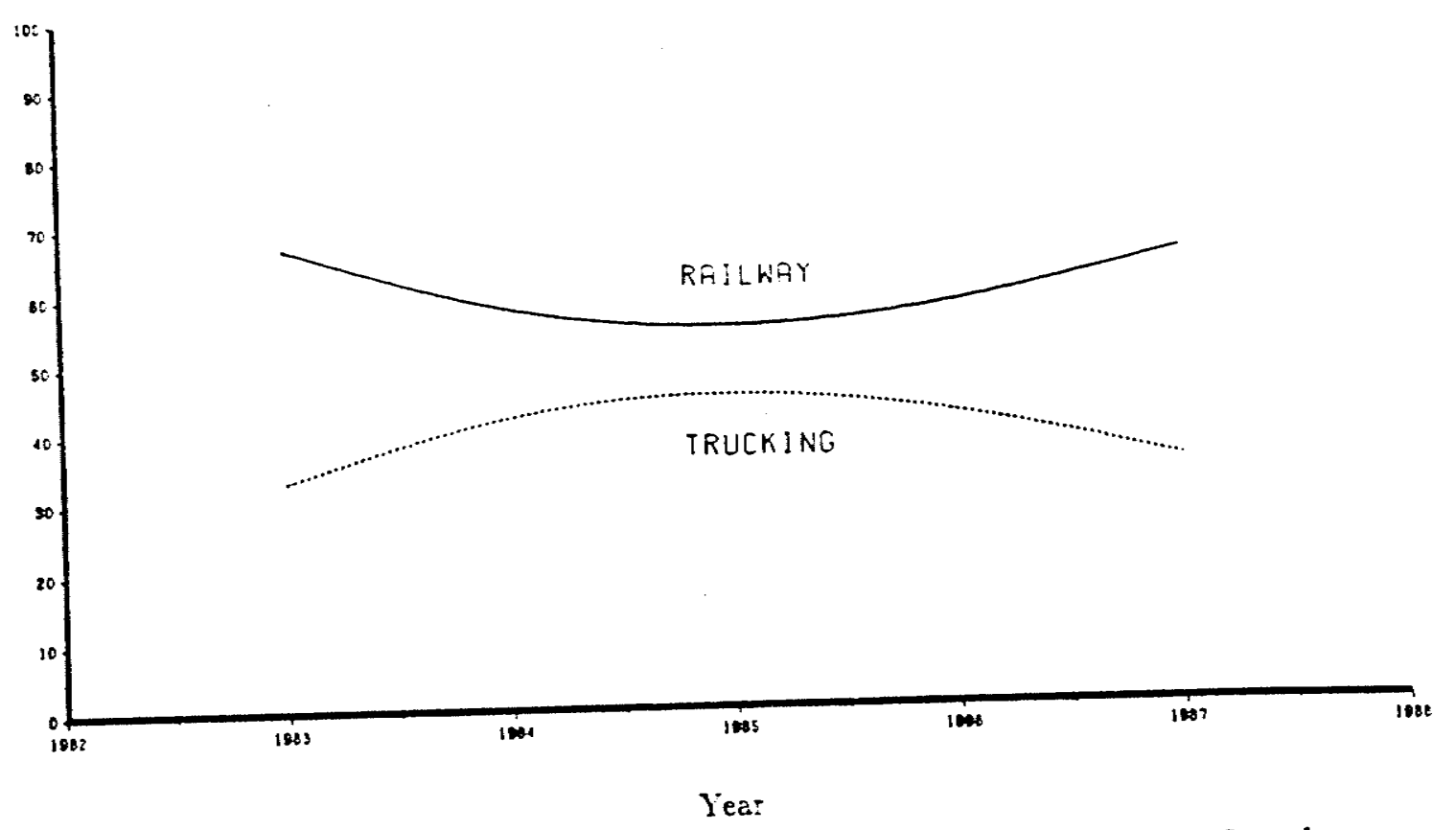

Figure A 5.16 EPI Truck/Rail Modal Split by Commodity Section Tonnage From Ontario to British Columbia 


\section{APPENDIX 6}

Percentages Link-by-Link Share of Interprovincial Railway and Trucking Volume by Commodity Section (1986) 
Table A6.1 FFB\&T Link-by-Link Share of Interprovincial Railway Volume 1986 (\%)

\begin{tabular}{lcccccc}
\hline$O: \backslash D:$ & Que. & Ont. & Man. & Sask. & Alta & B.C. \\
\hline Que. & & 1.0 & - & - & - & - \\
Ont. & 4.0 & & 1.0 & - & 1.0 & 1.0 \\
Man. & 1.0 & 16.0 & & - & - & 3.0 \\
Sask. & 1.0 & 26.0 & 2.0 & - & - & 20.0 \\
Alta & - & 3.0 & - & - & & 19.0 \\
B.C. & - & - & - & - & - \\
\hline
\end{tabular}

Table A 6.2 FFB\&T Link-by-Link Share of Interprovincial Trucking Volume $1986(\%)$

\begin{tabular}{lcccccc}
\hline$O: \backslash D:$ & Que. & Ont. Man. & Sask. & Alta & B.C. \\
\hline Que. & \multicolumn{7}{c}{18.1} & 0.4 & - & 0.7 & 0.7 \\
Ont. & 26.1 & & 2.1 & 0.6 & 2.1 & 1.1 \\
Man. & 1.9 & 4.1 & & 3.0 & 3.3 & 2.3 \\
Sask. & 0.4 & 0.5 & 1.8 & - & 3.2 & 1.3 \\
Alta & 2.0 & 1.3 & 2.3 & 2.9 & & 9.0 \\
B.C. & 0.4 & 0.9 & 1.7 & 1.2 & 4.8 \\
\hline \multicolumn{7}{c}{ less than $0.05 \%}$.
\end{tabular}


Table A 6.3 CMI Link-by-Link Share of Interprovincial Railway Volume $1986(\%)$

\begin{tabular}{|c|c|c|c|c|c|c|}
\hline$O: \backslash D$ & Que. & Ont. & Man. & Sask & Alta & B.C. \\
\hline Que. & & 1.0 & - & - & - & - \\
\hline Ont. & 6.0 & & - & - & 0.4 & 0.1 \\
\hline Man. & 0.3 & 2.2 & & 2.0 & 0.4 & 2.0 \\
\hline Sask. & - & 6.0 & 1.4 & & 0.2 & 4.2 \\
\hline Alta & 0.5 & 7.0 & - & 0.2 & & 56.3 \\
\hline B.C. & 0.3 & 4.0 & 0.3 & - & 5.2 & \\
\hline
\end{tabular}

Table A 6.4 CMI Link-by-Link Share of Interprovincial Trucking Volume $1986(\%)$

\begin{tabular}{lccccccc}
\hline$O: \backslash D:$ & Que. & Ont. Man. & Sask. & Alta & B.C. \\
\hline Que. & & 16.8 & - & - & - & 0.1 \\
Ont. & 9.9 & & 0.7 & 0.1 & 0.1 & 0.1 \\
Man. & 0.2 & 1.8 & & 1.2 & 0.4 & - \\
Sask. & - & 0.7 & 18.5 & & 18.9 & 1.2 \\
Alta & - & 0.5 & 7.3 & 2.7 & & 3.6 \\
B.C. & - & 0.1 & 1.0 & 0.3 & 13.4 & \\
\hline \multicolumn{8}{c}{} \\
\hline
\end{tabular}


Table A 6.5 FMI Link-by-Link Share of Interprovincial Railway Volume 1986 (\%)

\begin{tabular}{lccccccc}
\hline$O: \backslash D:$ & Que. & Ont. Man. & Sask. & Alta B.C. \\
\hline Que. & & 12.2 & 0.2 & - & 0.4 & 0.4 \\
Ont. & 8.1 & & 1.5 & 0.5 & 2.3 & 1.3 \\
Man. & 0.8 & 2.3 & & 0.2 & 0.1 & 0.3 \\
Sask. & 2.3 & 8.1 & 0.8 & & 0.6 & 16.5 \\
Alta & 2.4 & 5.6 & 3.6 & 1.9 & & 12.6 \\
B.C. & 4.4 & 7.1 & 1.1 & 0.4 & 1.8 & \\
\hline \multicolumn{8}{c}{} \\
\hline
\end{tabular}

Table A 6.6 FMI Link-by-Link Share of Interprovincial Trucking Volume $1986(\%)$

\begin{tabular}{|c|c|c|c|c|c|c|}
\hline$O: \backslash D$ & Que. & Ont. & Man. & Sask. & Alta & B.C. \\
\hline$\overline{\text { Que. }}$ & & 25.5 & 0.4 & 0.1 & 0.4 & 0.2 \\
\hline Ont. & 18.2 & & 1.7 & 0.5 & 1.5 & 0.5 \\
\hline Man. & 0.2 & 2.3 & & 2.1 & 1.2 & 0.2 \\
\hline Sask. & - & 0.3 & 3.1 & & 3.3 & 0.6 \\
\hline Alta & 0.1 & 1.1 & 3.2 & 10.7 & & 10.2 \\
\hline B.C. & 0.1 & 0.5 & 0.8 & 1.9 & 9.0 & \\
\hline
\end{tabular}


Table A 6.7 EPI Link-by-Link Share of Interprovincial Railway Volume 1986 (\%)

\begin{tabular}{|c|c|c|c|c|c|c|}
\hline$O: \backslash D:$ & Que. & Ont. & Man. & Sask. & Alta & B.C. \\
\hline Que. & & 9.4 & 2.1 & 0.9 & 2.9 & 2.4 \\
\hline Ont. & 17.9 & & 7.9 & 5.3 & 16.1 & 11.4 \\
\hline Man. & 0.9 & 1.6 & & 0.3 & 0.8 & 0.8 \\
\hline Sask. & - & 0.2 & - & & - & - \\
\hline Alta & 0.6 & 1.2 & 0.7 & - & & 0.8 \\
\hline B.C. & 6.0 & 6.9 & 0.9 & 0.4 & 1.6 & \\
\hline
\end{tabular}

Table A 6.8 EPI Link-by-Link Share of Interprovincial Trucking Volume 1986 (\%)

\begin{tabular}{lcccccc}
\hline$O: \backslash D:$ & Que. & Ont. & Man. & Sask. & Alta & B.C. \\
\hline Que. & & 19.0 & 0.9 & 0.6 & 1.3 & 0.9 \\
Ont. & 25.4 & & 3.1 & 1.2 & 4.0 & 6.7 \\
Man. & 0.4 & 2.6 & & 2.6 & 2.0 & 0.3 \\
Sask. & 0.1 & 0.2 & 0.6 & & 2.9 & 0.2 \\
Alta & 0.3 & 1.9 & 1.4 & 5.1 & & 6.7 \\
B.C. & 0.6 & 1.6 & 0.7 & 0.7 & 5.9 & \\
\hline \multicolumn{7}{c}{ less than $0.05 \%}$.
\end{tabular}

